Claremont Colleges

Scholarship@ Claremont

CGU Theses \& Dissertations

CGU Student Scholarship

2012

\title{
Idealism and Actualization. Saint-Just in Theory, Practice, and Exigency
}

Craig R. Schamel

Claremont Graduate University

\section{Recommended Citation}

Schamel, Craig R., "Idealism and Actualization. Saint-Just in Theory, Practice, and Exigency" (2012). CGU Theses \& Dissertations. Paper 82.

http://scholarship.claremont.edu/cgu_etd/82

DOI: $10.5642 / \operatorname{cguetd} / 82$

This Open Access Dissertation is brought to you for free and open access by the CGU Student Scholarship at Scholarship @ Claremont. It has been accepted for inclusion in CGU Theses \& Dissertations by an authorized administrator of Scholarship @ Claremont. For more information, please contact scholarship@cuc.claremont.edu. 


\section{Craig Schamel}

\section{Idealism and Actualization}

Saint-Just in Theory, Practice, and Exigency

Dissertation in Political Philosophy

Submitted to the Department of Politics and Policy in the School of Politics and Economics at Claremont Graduate University in partial fulfillment of the requirements for the Doctor of

Philosophy degree 
This dissertation has been duly read, reviewed, and critiqued by the Committee listed below, which hereby approves the manuscript of Craig R. Schamel as fulfilling the quality and scope requirements for meriting the degree of Doctor of Philosophy.

\author{
James H. Nichols, jr., Chair \\ Claremont McKenna College \\ Professor of Government
}

\author{
Sharon N. Snowiss \\ Pitzer College \\ Professor of Political Studies
}

\author{
Gary R. Kates \\ Pomona College \\ Professor of History
}




\begin{abstract}
Louis-Antoine Léon de Saint-Just (1767-1794) was a revolutionary, a statesman, and a political philosopher, yet it is largely only as a revolutionary that he is remembered. As a political person who occupied these three different but overlapping roles, Saint-Just is ideal as the subject and center of a study of actualization, the taking of political ideals into reality. Saint-Just 's political philosophy was that of an idealist, and yet he, by force of circumstance, ability, and audacity, had the opportunity in his short life to attempt to establish and put into practice his political ideals. In his work as a political person Saint-Just created templates for the understanding of the relationship between political theory and political action. Saint-Just's political theory is examined in relation to his political action, using the concepts of 'the natural', 'the civil', 'the social' and 'the political', concepts which are central in Saint-Just's political philosophy. Saint-Just's formulations of these concepts, concepts which have also been central to the history of political philosophy, and his understanding of the relations between these concepts, helps to establish him as a political philosopher of some importance, as does the theory and practice approach to politics which his attempts demanded and which his political life demonstrated. In Saint-Just's function as political philosopher the thesis finds the theoretical element of politics, which becomes redefined in its interaction with Saint-Just's other functions as statesman and revolutionary, the latter two of which correspond roughly to practice and exigency. As a theorist who is also a statesman in a context of exigency, or revolution, Saint-Just's political life is a constantly rearranged juxtaposition of theory, practice, and revolution, albeit one which never loses it essential ties to its philosophical base, even in the hours of greatest emergency. Such dedication to a philosophical base, one which refuses to dispense with political philosophy, demonstrates a new conception of political philosophy for the modern world, fills in elements of a theory of revolution as a phenomenon of both theory and action, and provides a contained case for examination of political philosophy and political action, questioning their disunity.
\end{abstract}

Idealism and Actualization: Saint-Just in Theory, Practice, and Exigency

Craig Schamel

Claremont Graduate University: 2012 
Acknowledgments

My deepest gratitude I express to my mother, Sandra Schamel, who has supported me with heart, soul and wallet, to my beloved late aunt Alice Mercurio, whose spirit and love motivate all of my actions, and to my dissertation committee, Jim Nichols, Sharon Snowiss, and Gary Kates; also to Bill Dunmyer, who encouraged me to return to school to finish the degree for which this dissertation is submitted, and who encouraged me to work on Saint-Just rather than on Hegel. A special thank you is due to Scott MacDonough, who has ardently supported, in word and deed, all of my efforts over the years, to the late Eliza Lloyd Moore, who encouraged me to rise above the immediate desires that surrounded me and to keep my eye on a larger goal, and to my loving boyfriend, Zane Liston, for putting up with my lack of availability and my stress during this endeavor. I would also like to thank my students at ASA Institute and those at the University of Redlands for reminding me of one important reason why I've stuck with academia, since they are that reason itself. I am grateful to Jean Schroedel at the School of Politics and Economics at Claremont Graduate University for her assistance, which allowed me to remain in the program when I otherwise would have had to leave for financial reasons. I would finally like to mention my gratitude to the late, great French scholar of the Revolution Albert Mathiez, whose work pulled me out of the reactionary miasma of Anglophone discussions of the Revolution and brought me up to a level of enlightenment which inspired and began the path to this dissertation. 
Table of Contents

Biography of Louis-Antoine Léon de Saint-Just

Note on the Works of Saint-Just

xvi

Note on Citations

xviii

Introduction

I. Theory (The Right of Practice) Saint-Just as Political Philosopher

The Concept of the Natural

The Concept of the Social

The Concept of the Civil

The Concept of the Political

II. Practice (The Theory of Practice) Saint-Just as Governor

Introduction

Areas of Policy

Suppression of the Ancien Régime

Expression of the Ideas of Natural, Social, Civil, and Political Within the Area of Policy 87

Institutional Foundation, Organization and Maintenance

Expression of the Ideas of Natural, Social, Civil, and Political Within the Area of Policy 100

Distribution of Goods

Expression of the Ideas of Natural, Social, Civil, and Political Within the Area of Policy 116 
Introduction

Areas of Policy

Suppression of the Ancien Régime

Expression of the Ideas of Natural, Social, Civil, and Political Within the Area of Policy 145

Institutional Establishment and Maintenance

Expression of the Ideas of the Natural, Social, Civil, and Political Within the Area of

Policy

Distribution of Goods

Expression of the Ideas of Natural, Social, Civil, and Political Within the Area of Policy

Revolution

Expression of the Ideas of Natural, Social, Civil, and Political Within the Area of Policy

Conclusion

Chart of Relations of Central Concepts in Saint-Just

Bibliography

Notes 
......il nous remplit de stupeur. Rien en lui ne pourra paraître vrait; c'est que notre verité consiste en ce qui nous sommes tous....politiciens. Aussi ne saurions-nous comprendre l'homme qui parle non pas mieux que d'autres, mais autrement. C'est l'homme légendaire.

\section{Biography}

Louis-Antoine Léon De Saint-Just (August 25, 1767- 10 Thermidor, Year II [July 28, 1794]) was born into a family of the lower nobility at Decize, Nièvre, Bourgogne, France, moving in 1776 at age nine with the family to Blérancourt, Aisne, Picardie, where within a year, his father died. He was educated at Le Collège Saint-Nicolas, a small, reformist

Oratorian school in Soissons, Aisne. During his time at Saint-Nicolas, he wrote a manuscript entitled Monographie de Château de Coucy, an antireligious satire which secularized a prior tract entitled L'Histoire de la Ville et des Seigneurs de Coucy, a 1728 work by Dom Toussaint du Plessis. In 1786 Saint-Just had an argument with his mother, the issues in which are unknown, and fled his home in Blérancourt for Paris, taking some family silver and other effects without permission. Once there, he sold these family possessions and moved into the Hôtel Saint-Louis, in a bohemian district of Paris known for its theaters, clubs, and baths, all of which Saint-Just frequented. While he was in Paris, his mother reported the theft of the family possessions and named her son as the suspect, and Saint-Just was eventually found and arrested and spent six months in a house of detention that housed many young men who had been charged with 'libertinage'. At his release, he was escorted back to Blérancourt by authorities. Saint-Just sometime soon thereafter entered the Faculté de Droit De Reims as a student, eventually obtaining at least a clerkship and possibly a licencié ès lois or a licencié en droit. Important revolutionaries with whom Saint-Just would later work closely, including Georges Danton, Georges Couthon, Pierre-Louis Prieur De La Marne, Antoine Quentin 
Fouquier de Tinville, and Jacques Alexis Thuriot also attended the Faculté de Droit at Reims, though somewhat earlier than Saint-Just. While at Reims his interest drifted toward literature and theater, and he wrote a one act comedy in verse titled Arlequin-Diogène, an incisively critical and socially and politically conscious work. This work was followed by an even more biting and socially and politically critical work called L'Organt, a 'poem in twenty canto' described by some as 'violent' and 'pornographic'. Some considered the work's protagonist, Antoine Organt, to represent Saint-Just himself. The publication of this work was accompanied by an order for its seizure. After the publication of L'Organt and the controversy around it, Saint-Just attempted to defend himself by writing and circulating Dialogue entre Monsieur D. et l'auteur d'«Organt», a work which has been lost. In 1790 he wrote his only fully completed work in traditional political theory, L'Esprit de la Révolution et de la Constitution de France, which was published in early 1791.

During the year 1790 Saint-Just became both increasingly distinguished in the department of Aisne and increasingly radical in his political action. Along with his brother-inlaw Emmanuel Decaisne and others, he formed the local chapter of the Garde Nationale at Blérancourt and then attempted to push it in a revolutionary direction. He also successfully formed and saw through a plan for a policy of mutual defense of the regional chapters of the Guard, and was named Commandant d'Honneur des Gardes Nationales of the canton in July. In March of 1790 he had exposed and read a counterrevolutionary satire, calling a special meeting to denounce it. At this meeting he publicly swore an oath of allegiance to France and to the National Assembly. In May he was elected secretary of the local district assembly at Chauny, Aisne, and later, in October, he was elected president, but resigned immediately when questions about his age arose. Also in May he was appointed spokesperson for the canton of Blérancourt to the convention of electors meeting to choose the president of the department of Aisne. In June he led a local offensive against the paying of the seignorial 
tribute, and in July he was a delegate to the Fête de la Fédération, a celebration of the first anniversary of the Revolution. In August 1790 he wrote an introductory letter to Maximilien Robespierre, already a distinguished representative to the National Assembly from Pas-deCalais (Artois). The letter praised Robespierre, informed him of the local situation, and asked for assistance. By October 1790 Saint-Just had been frequently suggested for and twice put forward as a candidate for the National Assembly, but was both times rejected because he did not meet the minimum age requirement. Failing to ascend to the National Assembly a third time in 1791, again due to his age, Saint-Just remained in Aisne, battling in the local government meetings with partisans of the ancien régime. During 1791-92 he composed his second work of political theory, Du Droit Social, usually referred to as De La Nature ${ }^{2}$, though he apparently completed only two of the four books that he projected would comprise the work. In 1792 he worked on his next campaign for the Legislative Assembly, ${ }^{3}$ and, partly due to some changes in the laws and the alteration of some financial documentation by friends in local government, he was able to meet the minimum requirements for a representative, and was elected to the National Convention.

Upon arrival in Paris as a national representative, Saint-Just immediately affiliated with the left wing of the Convention, known as the Mountain, and with the Jacobin Club, one of the most centrally important political forces of the Revolution. His speeches at the Jacobin Club were well received and he was almost immediately elected to the Club's constitutional committee. On 23 Brumaire of Year $\mathrm{I}^{4}$ [November 13, 1792] he gave his first speech to the National Convention, in which he addressed the question of whether or not the king could and should be executed. Saint-Just spoke in favor of the king's execution and his speech was enthusiastically applauded and quoted afterward by many. His speeches and reports thereafter were remarkable for their compelling rhetoric, their eloquence, and for their expression of political-philosophical ideals and the connection of these to policy. 
On 9 Nivôse, Year I [December 29, 1792] he was elected president of the Jacobin Club. After speeches to the National Convention in Pluviôse [January and February] on the reorganization of the War Ministry and of the army, Saint-Just was sent into the field, to his home district of Aisne, to recruit and supervise the armed forces in the region. He returned to Paris in Ventôse [March 1793], reporting his despair and alarm over the state of the army. After his return, he developed the plan for what would become the Constitution of Year I, a radical republican constitution that favored direct popular control of the government and a centralized organization. The Constitution, though considered a masterpiece of republican legislation and ratified by the Convention, was never put into effect due to the exigencies of the Revolution and the Revolutionary War. The plan for and philosophy behind this Constitution were laid forth in speeches to the Jacobin Club, in Du Droit Social, and in his Speech on the Constitution of Year I on 5 Floréal, Year I [April 24, 1793].

In response to grave and immediate threats to the republic from without and to the Revolution from within, the members of the standing executive committees of the Revolutionary government had created, on 5 Germinal Year I [March 25th, 1793], a special committee, the Committee of Public Safety, which, together with another committee, the Committee of General Security, would have authority over the other committees of the executive element of the government. Saint-Just was elected to the Committee of Public Safety on 11 Prairial [May 30, 1793]. His election to the Committee of Public Safety coincided with a rapidly developing and successful purge of the right wing of the Convention, whose members were later known as the Gironde, and Saint-Just was charged with explaining their crimes and with the justification for the arrest of many of the right-wing representatives, which duty he performed in a speech to the Convention on 20 Messidor Year I [July 8, 1793]. In the Committee of Public Safety, Saint-Just was elected general correspondent, and was appointed to the subcommittee on the Constitution and to a subcommittee charged with 
oversight of the military suppression of internal revolts against the Revolutionary government. As a concomitance to his work on the military subcommittee, he was sent to his home department of Aisne on a mission to the armies there, returning by 12 Thermidor, Year I [July $\left.30^{\text {th }}, 1793\right]$. Reduction of the size of the Committee of Public Safety on 22 Messidor, Year I [July 10, 1793] along with a consolidation of its membership by partisans of the left wing of the national government and many other factors militated to the increasing authority of the Committee, which, under the leadership of Saint-Just and eight others, established, inter alia, a planned economy and severe punishments for treason to the Revolution.

Formalization of the centrality of the Committee of Public Safety in the government and the establishment of a sanction for its dictatorship was requested by Saint-Just in a speech to the Convention on 19 Vendémiaire, Year II [October 10th, 1793], and granted unanimously by the Convention. In the 19 Vendémiaire speech, Saint-Just also formally declared the government of France to be a revolutionary government, and this was also endorsed by the Convention. Saint-Just was then sent on a third mission to the armies, this time to the regions of Alsace and Nord, along with another member of the Committee of Public Safety, Philippe LeBas. The mission, which was really two missions broken up by a week in Paris, lasted several months. On this mission Saint-Just supplied and rewarded the armies and fought on the front lines alongside them, enacted severe disciplinary measures, including the execution of those supporting the counterrevolution directly or indirectly, forced by government order the wealthy in the region to loan money to the armies and confiscated their belongings for the armies and the state, ordered the arrest of the regional nobility, and appointed the exceptionally young generals Lazare Hoche, Jean-Charles Pichegru, and Jean-Baptiste Jourdan as commanders of the Revolutionary armies. The mission to Alsace was also a mission of dechristianization, and Saint-Just ordered statuary and other religious icons and objects destroyed or appropriated, yet also balanced his actions with expressions of sympathy 
for the religious beliefs of the people of the region, rebuking those who were overzealous in the dechristianization campaign.

Shortly after Saint-Just's return to Paris on 25 Pluviôse, Year II [February 13, 1794], he was elected president of the National Convention. In speeches and reports to the Convention in the winter of Year II, he continued to present his political-philosophical theories and to base his arguments, conclusions, and policies on these theories, introducing his conceptions of sovereignty, republican government, revolutionary government, the civil realm, the political realm, and the social realm, drawing on his work Du Droit Social. Saint-Just during this time also played a central role in the factional contestations within the revolutionary government, creating the Amalgamation Policy, which refused to differentiate between those on the right opposed to the revolutionary government and those on the left opposed to it. Most of his speeches and reports during this time proposed and resulted in laws and decrees. The report to the Convention of 13 Ventôse, Year II [March 3, 1794] established the basis for the seizure of the property of the wealthy and its redistribution to the poor, which policy was enacted following Saint-Just's report. With continued threats to the Revolutionary government from without and within, Saint-Just, in keeping with the Amalgamation Policy, in Ventôse and Germinal of Year II [March and April of 1794] also proposed decrees against major factions from both right and left who were in opposition to the government. These decrees were adopted by the Convention, and many representatives and other political figures from the right and left were tried and imprisoned or guillotined.

In the early spring of Year II Saint-Just and other members of the Committee of Public Safety and the Committee of General Security began sleeping in their offices at the Palais des Tuileries due to the heavy workload, the exigencies of maintaining the Revolution, and threats to their lives. Saint-Just slept on a cot in his office. Soon, however, he was sent on a fourth mission to the armies, which, except for brief reappearances there, took him away from 
Paris from Germinal to Messidor of Year II [late April to late June of 1794]. It is also during the springtime of Year II that Saint-Just is believed to have put together his notes and observations on the state of affairs within the government and his reflections on political ideals into another ultimately uncompleted political-philosophical work entitled Fragments d'Institutions Républicaines, a work which developed his idea for social institutions which would serve as both the progenitor and the guarantor of a peaceful, just, and lasting government. The work is more sad and romantic than his prior works and in it Saint-Just expresses his woundedness over what had happened to his ideals and the ideals of the Revolution.

The spring and early summer military mission was to the armies of the northern front in Picardie and Nord-Pas-de-Calais. Again Saint-Just and Le Bas were sent together and SaintJust again fought alongside the armies and implemented many of the same procedures from his earlier missions. With communiqués to and from Paris, Saint-Just commanded the armies, evidencing great ardor and exercising severity, especially with regard to the punishment of those fleeing or avoiding battles. His work there was considered very successful, and during his time on the front and thereafter important victories began to accrue to the Revolutionary Army, victories which quickly pushed back the coalitional counterrevolutionary armies of Europe so far that France occupied all of Belgium by the summer of Year II. During SaintJust's time at the front he stayed in close communication with Paris, and he, Robespierre, and some other members of the Committee for Public Safety came increasingly to believe that the people would not be able to manage to hold on to the Revolution without religious inspiration, and that a complete secularization of the country would not be in the best interest of a lasting republic. They created a new religion for Revolutionary France which was founded on the ideas for social institutions in Saint-Just's Fragments, which work came increasingly to be the theoretical working out of the High Revolution. The new religion, the Cult of the Supreme 
Being, was declared the state religion of France and made Reason the new god of the revolutionary republic. Saint-Just returned to Paris briefly for the inaugural celebration of the Cult on 20 Prairial [June 8th, 1794], receiving joyous accolades from the crowds.

After the Festival of the Supreme Being Saint-Just returned again to the war front. When he finally returned to Paris on 10 Messidor [June 28, 1794], repression of the enemies of the revolution had again increased significantly owing partly to the Laws of Prairial, new laws of punishment and suppression of the Revolution's enemies which were passed on 22 Prairial [June 10th, 1794]. The environment he returned to in Paris was one of paranoia and suspicion. Saint-Just and the members of the Committee of Public Safety, however, had continued to agree significantly on policy and to present a largely united front, and the Committee, with endorsement from the Convention, had grown in power and scope of authority, and had become the de facto and then the de jure director of even its twin executive committee, the Committee of General Security. The Committee of Public Safety increasingly found evidence that English spies and their dupes had penetrated into the heart of the Revolutionary government, and this further increased the environment of suspicion and fear. While the Committee of Public Safety continued to supervise most areas of the government with much agreement, its internal discussions over questions of loyalty began to cause friction, while at the same time members of the Committee of General Security began to attack the Committee of Public Safety. During most of Messidor [June and July 1794] SaintJust supervised the government and worked especially on the supervision of the national police, attempting to balance his desire to end the the repression with his ardent belief in the imminent dangers facing the government. Factionalism though, began to split the Committee for Public Safety, and Saint-Just attempted to reconcile its two groups, one consisting of Maximilien Robespierre, Georges Couthon, Jean Bon Saint-André, and Pierre-Louis Prieur De La Marne, and the other of Lazare Carnot, Jacques-Nicolas Billaud-Varenne, and Jean- 
Marie Collot d'Herbois. Bertrand Barère and Claude Antoine Prieur de la Côte d'Or, the other members of the committee, remained neutral in the disputes.

On 9 Thermidor, Year II [July 27, 1794] Saint-Just came to the speakers' platform at the Convention to deliver a speech with three significant elements. The speech was to finally propose the official establishment of the social institutions of his Fragments d'Institutions Républicaines. The speech was also intended to defend Maximilien Robespierre from accusations of aspirations to dictatorship and to defend Robespierre's suspicions and accusations against various persons in the government. Finally, the speech was a touching attempt to reunite the members of the Committee of Public Safety and to show consideration to and reconcile with the Committee of General Security in the name of solidarity and the ideals of the Revolution. Shortly after Saint-Just began speaking he was interrupted violently by certain other deputies and shoved off of the platform. He calmly attempted to return to the platform to continue speaking, but an order for his arrest and that of Robespierre was proposed, voted on, and passed. Augustin Robespierre, Georges Couthon, and Philippe LeBas insisted on joining Saint-Just and the elder Robespierre, and all were arrested and jailed.

The Revolutionary government of the city of Paris, called the Paris Commune, the Paris National Guard, and many private citizens, on hearing of the arrests of Saint Just and the others rallied to free them, and marched on the headquarters of the Committee of General Security. Upon arrival at the headquarters of the Committee of General Security, the commander of the National Guard, François Hanriot, was arrested, and the rest of the troops began dispersing, looking for Saint-Just and his compatriots, who had been separated and moved to various different locations. As news spread of Hanriot's attempt and his arrest, Guardsmen from many sections surrounding Paris and army troops convened, marched to attempt to free the arrested representatives, and surrounded the National Convention, which was still in session. Saint-Just and the other arrested representatives however, though freed, 
insisted on abiding by legal procedure and refused to flee. At the same time Hanriot, who had been freed, and others hesitated to attack the National Convention. The Convention though, felt itself still under threat, and voted to declare Saint-Just and his compatriots stripped of their offices, leaving them without legal sanction or recourse. On hearing this, Saint-Just and the others regrouped and began to attempt to supervise what was now an insurrection against the government. As their attempts began though, the delegates to the Convention were haranguing the troops surrounding them and succeeded in confusing and dispersing them. Agents of the Convention then were sent to capture Saint-Just and the others, and did so inside the main Paris City Hall.

Saint-Just is reported to have remained impassive at his capture, and for the remaining hours of his life. He was tried for treason the following afternoon at the Revolutionary Tribunal, placed in an open cart, and transported amid crowds of onlookers to the guillotine, where he was executed in the early evening of 10 Thermidor, Year II [July 28, 1794], one month shy of his twenty-seventh birthday. 
Note on the Works of Saint-Just

Although the earlier literary works of Saint-Just are not examined in this dissertation ${ }^{5}$, they should not be thought of as apolitical, and show consistency of some of Saint-Just's ideas over time. The dissertation however, properly considers only L'Esprit de la Révolution et de la Constitution de France, Du Droit Social, and Fragments D'Institutions Républicaines, as well as speeches, reports, and notes of Saint-Just during his political career, and focuses primarily on the work after L'Esprit.

I follow herein the generally accepted though still debatable order of Saint-Just's theoretical works, which considers L'Esprit de la Révolution to have been written in $1790, D u$ Droit Social to have been written in 1792-Year I [1793], and the Fragments to have been written in Year II [1794]. ${ }^{6}$ Not having been able to look at original manuscripts and notes, I cannot adequately pronounce judgement on the order of Saint-Just's writings, yet this order seems important, since the content of Saint-Just's speeches and reports directly reflects or repeats, sometimes verbatim, ideas in his theoretical writings, or vice versa. The thesis itself though questions the linear ordering of ideation and policymaking, and the possibility is also raised by Ollivier, for one, that Saint-Just accommodated his theoretical writings to meet the conditions of the moment. ${ }^{7}$ Support for placing Du Droit Social after L'Esprit de la Révolution in time, against Ollivier, is that Saint-Just's unique and significant conception of the social is not present in L'Esprit. To have developed the promising conception of the social which Saint-Just does in Du Droit Social and then to dispense with it altogether in a subsequent work seems unlikely. In addition, all references to the social in $L ' E s p r i t$ either connect it immediately to Rousseau's idea of the social contract (e.g. 'pacte social', 'contrat social') or use the concept in conventional and unelaborated ways. In addition, with a proper understanding of the seemingly oddly anachronistic concept of 'the king' at the end of $D u$ 
Droit Social, thus, of this concept arguments for an earlier or later date fall by the wayside. I follow Anne Quennedey in taking Chapter II of the Fragments as in fact extraneous thereto and instead a supersession of Chapter II of Du Droit Social, and importantly, I adopt her use of $\mathrm{Du}$ Droit Social as the more appropriate name for what is heretofore in Saint-Just scholarship referred to as De La Nature. Readers should be aware then that everywhere else heretofore, except in Quennedy and in this thesis Du Droit Social is known by the name De La Nature.

The Fragments is a collection of notes, most of which take the form of a manuscript. There are clear connections between the content of these notes, which were published as Fragments d'Institutions Républicaines, and Saint-Just's last, undelivered speech to the Convention, the speech for 9 Thermidor, Year II, as there are clear connections between his Speech on the Constitution of Year I and Du Droit Social. Again here, the order of the speeches in relation to the theoretical work is debated, and this debate relates to one of the central questions of the thesis, though the questions about the relationships of theory to action persist in their prominence in the consideration of Saint-Just's political work and experience no matter what order of works one follows.

Omissions, Changes, Suppressions, Alterations

In Saint-Just's manuscripts there are many strikethroughs and replacements, which alone makes the texts difficult to put together coherently. In addition, Saint-Just wrote portions of perhaps his most important text, $\mathrm{Du}$ Droit Social, both upside down and backwards starting from the back of his notebook, and then, using the same notebook, wrote other and apparently later parts of the same manuscript starting from the front of the notebook and right side up.

Aside from problems with Saint-Just's style and manner of composition, there are, 
when examining the works of Saint-Just in relation to his life and reputation, questions about alteration and suppression of his work by others, both intentional and unintentional. Regarding the latter, many sheets of paper were collected and not collated until quite some time after Saint-Just's death. Some difficulty presented itself in distinguishing Saint-Just's work from that of others whose notes were thrown together somewhat haphazardly by Edme Bonaventure Courtois and other officials of the post-Thermidorian reaction, and thus some notes attributed to Saint-Just seem dubious. In addition, there are scholars of Saint-Just who have published and discussed falsified works. ${ }^{8}$

Note on Citations

When Saint-Just's work is cited directly herein, whether the reference is to manuscripts, notes, or transcribed speeches and reports, the citation lists the work of Saint-Just followed by the particular part of the work when applicable, followed by Saint-Just's name, then the name of the editor of the edition of his works to which the note refers, and then the page number cited, e.g. EDR Part III, Chapter II, Saint-Just - Abensour, 401. Abbreviated references to SaintJust's three major theoretical works are as follows:

\section{EDR - Esprit de la Révolution et de la Constitution de France}

DDS - Du Droit Social (De La Nature)

\section{FIR - Fragments D'Institutions Républicaines}

When passages that Saint-Just struck out in his notebooks or manuscripts are quoted, or when use is made of text that was apparently superseded, I have tried to note this with the word 'strikethrough' following the citation. I have made use of strikethroughs at times since I my view they greatly help elucidate key parts of Saint-Just's thought which would otherwise be missing, and since they at least give an idea of how to fill in some important gaps in the 
expression of his ideas. 


\section{Introduction}

This work has a number of aims. One of these aims is to examine actualization in political life, that is, to examine the relationship between political philosophy or theory and political action or practice. A second aim is to present original work that addresses SaintJust's political philosophy and political action and that does so in English, since there is very little of such work, though thoughtful and scholarly works on Saint-Just in French abound. A third and related aim is to show that Saint-Just's political philosophy, his political action, and his entire political experience are worthy of consideration for those interested in the relationship between theory and action in a political framework generally, for those interested in the theory and action of the French Revolution in particular, for those interested in the question of theory and action in any revolution, and for those interested in the development of revolution itself as a conceptual and political category. A final aim was not an original aim, but developed early on in my understanding and attempt at explication of Saint-Just's theory, and this aim is to show that Saint-Just is prescient in his placement of the social as central for political philosophy and political science, and that he is of interest and value in the ongoing attempts by those from different disciplines to define and elaborate the idea of the social, and to elaborate a theory and practice which makes an idea of the social, in contradistinction to the political, of central importance.

With regard to the first aim, I have not herein distinguished between political philosophy and political theory, and have used them sometimes interchangeably. This was done in order to narrow focus, so as to not spend too much time on secondary questions, and because in the scholarly world the terms are often used effectively interchangeably, as evidenced by the fact that the same objectives, material and themes form the content of 
curricula in academic departments and divisions whether or not these are taught under the label 'political philosophy' or 'political theory'. This said, theory as opposed to philosophy does already have some tendency toward action in it, and is usually defined in relation to action, whereas philosophy seems to reserve the right to be considered as purely speculative or reflective, without any necessary engagement in the political world via action, and there is an irony in this contemporary nuance in that $\theta \varepsilon \omega \rho i ́ \alpha$ has an original sense as pure spectator activity. ${ }^{9}$ In any case, I have felt that both 'theory' and 'philosophy' in the senses in which we use them in political science stand as sufficiently homologous in relation to 'action' and 'practice' to form an antipode to the latter terms, and that such an apposition is valuable ground for examining fundamental questions about what one is doing when one does activity that has traditionally been called 'political'.

With regard to the concomitant question of the difference between 'practice' and 'action', there is a similar distinction to be made in that 'practice' carries the sense of already being connected back to theory, or to some type of thought, while action seems to want to reserve the right in all of its senses to not carry a necessary implication of anterior thought. Herein, I favor 'action' to describe what is usually meant by the question of the relation of theory to practice, though certainly this question as a problématique is readily understood in an interchangeable way as the question of theory and practice. I favor 'action' for two reasons. One is that, since 'practice' does carry the idea of a relationship to theory in its basic sense, and because I am here interested in examining that very relationship between activity that is largely of the domain of activity which is not considered to be primarily from the domain of thought, I want to remove a connection as much as possible for the sake of radical understanding. The second reason for favoring 'action' overall as the term for a province of political activity distinguishable from thought is that, in my differentiation of 
revolution from other political states, and in my analysis of Saint-Just, 'practice' has a different meaning and function; it indicates an ideal state as it would exist if politicalphilosophical ideals could be actualized, and as such occurs as the rubric of the second section of this work and as part of its title. Thus, this second justification for favoring 'action' over 'practice' in the general aim of the work is to avoid confusion in terminology. With regard to actualization, the conception of action understood herein is one of action as, more particularly, action which pertains to the realization of ideas which have traditionally been called political ideas, and this definition necessarily carries within it the idea of intention. Action herein also takes on the sense of a criterion in that it requires both an intention of realization and an attempt at such, and this is the process of actualization.

The second aim of the thesis is justified again, by the lack of serious and scholarly attention to Saint-Just in the Anglophone world. This lack is considered important partly because of what I see as the increasing relevance of Continental idea bases in American political thought, but also by the skewing of particularly the American political spectrum toward the conservative and reactionary, which, given the understanding of revolution as related to radicalism ${ }^{10}$ which is the operative understanding herein, allows little room for the consideration, development and legitimization of revolutionary thought and action.

The third multipartite aim requires no further clarification here, but the fourth aim is primarily the aim which has posed the questions which are the most interdisciplinary. While the examination of the question of the relationship between theory and action is, in my view, still infrequent across disciplines, the question of the social and its conceptual content and the attempts to develop the concept in relevant and valuable ways have occurred more frequently outside of political science than they have occurred inside of it, in disciplines such as history, with the development of 'social history', and in sociology. Since this work is a dissertation in 
political philosophy prepared under the auspices of a political science division, I have had to try to remain relevant and thematic in relation to these disciplines and I have attempted to connect the questions that are raised by Saint-Just's experience with the concept of the social and otherwise to the discourses of political philosophy and political science, though inevitably, especially with regard to the idea of the social, exploration in other areas has occurred to some extent. Though this is necessarily the case, I have felt that this is not a work in history, historiography, or in sociology, or in any of the other areas into which it could have delved more deeply, and so that overall this is an attempt to make the questions germane to the discourses of political philosophy and political science while still being innovative and also interdisciplinary to a requisite degree, and this should be kept in mind.

That said, the work is nevertheless influenced rather significantly by the Classic historical school of interpretation of the French Revolution, and especially, as indicated in the acknowledgements, by the work of Albert Mathiez. Since partisans of this Classic school, and Mathiez himself, are largely historians, the work often finds itself looking backwards into political-philosophical discourses from a theoretical base developed elsewhere. The approach I try to take herein overall is an approach which I call synthetic, in that it is an attempt to construct something rather than to analyze something by breaking it down into component parts. This approach is inspired by Mathiez, and particularly by Mathiez's attempt to understand the French Revolutionaries in terms of their own consistency of thought and action, and in terms of their place in a larger historical consciousness. The synthetic attempt then I see as focused on building a new metatheory rather than on analyzing various prior theories. Thus, I try to look at Saint-Just and his entire experience as instrumental in building some small part of a theory of the social, of the relationship between theory and action, and of the idea of revolution as it relates to action and thought, with all of these tied to a presumably developing 
historical consciousness, or at least one that is capable of being developed. The idea of a metatheory as historical is here particularly informed by Marxian-Hegelian scholarship and practice. The emphasis on historical development in Hegel then to some extent becomes an interdisciplinary link between history and political philosophy. Despite the inspiration from these theoretical frameworks, I have tried to take into account conservative and liberal thought and I also have attempted to keep an eye toward the transcendence of all prior modes of interpretation and philosophizing, as any attempt at some small contribution to a metatheory might ideally do, and I hope that this attempt has not resulted in too much of a pastiche.

The theses of this work are really in two forms, with one thesis being in the form of an argument, though one that mostly simply lays forth and explicates Saint-Just's political philosophy as evidence. This thesis is that Saint-Just's understanding of the natural, the social, the civil, and the political and their relationships establishes him as a political thinker of some value and importance. The other theses are two and are in the form of questions, to wit: What can Saint-Just's political experience offer to us in terms of knowledge about the nature of political philosophy and political action and their relationship, and in terms of developing the concept of revolution and the concept of revolutionary thought?

In an examination of such questions, one might ask, "Why Saint-Just?" The questions with which the thesis is concerned could have been explored in a different way, and there might be many suitable candidates for a case study with regard to such questions. In answer to the question I would say that the questions herein emerged largely from looking at SaintJust specifically, and not the other way around. That is, the interest in Saint-Just came first, but it certainly occurred in a particular context of past attention and experience, which included an increasing interest in what I saw as an odd and tendentious disposition in Anglophone scholarship with regard to the French Revolutionaries, and in particular with 
regard to the thought of the Comités, one which seemed to increasingly subsume all scholarly consideration under an effectively dismissive penumbra of focus on the supposed crimes of the Revolution.

With regard to the organization of the content within the three main parts, Theory, Practice, and Exigency, the discussion has a conceptual center which revolves around variously, each of the four concepts which I see as being central in Saint-Just, both in SaintJust's emphasis on these concepts themselves and their relationship to one another in his theory. Inevitably, with such relational concepts, there is much overlap in any discussion, and so the conceptual divisions within the various policy areas all interrelate, and this should be kept in mind. The three 'policy areas' were chosen both because of their frequency as topics of the treatment of Saint-Just by other scholars, and because these scholars' focus on these areas made good sense to me in consideration of the specific assignments and work of SaintJust in his positions within the revolutionary government and in consideration of the evidence which is available in the form of documents and second-hand testimony. The fourth 'policy area' of 'revolution' is a policy area in the sense that the revolutionary government spent much time on its own organizational endurance and survival, but its grouping here is also an attempt to look forward to some extent toward a theory of revolution itself, out of which templates for policy and procedure might grow.

Saint-Just's life as a referent and example for the combination of theory and action retains its first cogency in that Saint-Just did inarguably both write political theory and perform political action. This is undeniable even if one wishes to argue the point of the quality of Saint-Just's written theory or its fit into traditional standards of what constitute political theory or political philosophy. It is hard to deny that Saint-Just fashioned political 
theory in some sense, even if this theory was subservient to action, and always responsive to it, that is, even if the traditional theory to action order was reversed, which possibility this entire thesis suggests is noteworthy.

The context of my interest in Saint-Just though pointed toward certain conceptual foci beyond those that might emerge from merely a focus on the texts of Saint-Just and his interpreters. This context included my own political experiences with revolutionary organizations in New York and Paris, which included attempts to found new organizations, and this is part of the reason for setting the stage for thinking about the questions by noting the relevance of foundation and of praxis. The tendentiousness of writing on the Revolution, barely disguised in scholarly disinterestedness, informed my taking notice of ideology as a referent for the thesis questions. The emergence of the questions organically, and out of the particularities of both my active political experience and my path from a close reading of Saint-Just to the general questions this reading produced comported with and brought to more attention the relevance of induction as a logical method in its basic sense of lines of inference which run from the particular to the general. What also emerged from the reading of SaintJust was an interest in the temporal aspects of theory and action, an interest in their juxtaposition and position in time, and this is reflected in the referent of narrative. Finally, explorations in political philosophy led me to examine the thesis questions in the milieu of the battles over modernity and its future that form a large part of its relevant content in the contemporary period, and I retain an ultimate context of philosophy as far as relevance, and in fact part of what the thesis strives to do is to preserve the value of philosophy in its political aspect, even if this means that political philosophy is transformed and the concept of the social stands in its conceptual stead. Given these points of focus at the level of general categories of questions pertaining to knowledge in political science, I try to situate the thesis within them 
initially. Below, the second section of the introduction then briefly locates the thesis questions then within political science and political philosophy by using these frameworks of interrogation and interest: philosophy, utopia, praxis, ideology, narrative, logic, and foundation, before going on to talk in more detail about Saint-Just's theory and action, and so this section can be read first, or the specific analysis of Saint-Just's theoretical work and his political practice and their interaction can be read first and then placed into this context. I leave it to the reader to decide which order suits him or her better. 


\section{Philosophy}

The question of the theorist as actor is addressed by Aristotle, who believed that the busyness of the politician was inimical to the life of contemplation, which life and activity for Aristotle was an end in itself. ${ }^{11}$ At least a few questions of importance emerge from Aristotle's view. Who of those who have done political philosophy or of those who have conceived of themselves as political philosophers has not seen the beauty, peace, contentment, and even happiness of the life of contemplation? And yet, whence this contentment and relative peace? Could the desirability of this life of contemplation actually reside in the undesirability of the active political life, the life of the politician? If so, might it not follow that a change in the nature of the active political life could bring about a change in the nature of the life of contemplation? Is contemplation and the life dedicated to it escapism? Terence Ball writes, "[A] sequence of political immersion and subsequent retirement is a biographical fact for many political theorists." ${ }^{12}$ This question of the order of active political experience and theory is an interesting and perhaps important one, and in fact Saint-Just's experience seems to demand that we go a step further and call into question sequence altogether. The next step might be to see the interaction of these two roles or states as a dialectic that is alive at every moment. Representation of such a constant dialectical interaction as Saint-Just's political experience seems to show is then difficult because of the idea of sequence existing as something involving two enduring and static states which can be adequately described and distinguished. In questioning sequence, reversal of the common sequential order is a logical step in a line of questioning about theory and practice. This reversal is the idea of action being necessarily prior to theory, and yet even this sequence is in turn made immediately intermediate by the realization that both of these sequential placements of the theoretical can 
occur simultaneously. That is, that the theoretical can be formed from the actual even as it is simultaneously forming the actual. It is both in the area of this simultaneity of direction of theory and action, and in the content of his political theory that Saint-Just's revolutionary experience presents us with new possibilities for conceptualization of political philosophy.

Perhaps more importantly, the distinction between the vita contemplativa, or bios theōrētikos ${ }^{13}$ was traditionally made for the few, for the philosophers, or, for the free. But Saint-Just, in his Spartan vision of something like the peaceful end and existence of a communal state, the state that for him the Revolution was to bring about, wants to bring to all persons the peace, and peace of mind, that formerly had been available only to free persons, primarily philosophers for Aristotle, or, for all those who engaged in the political, for Hannah Arendt. Thus, the Revolution and its end for Saint-Just were a testament, and an active one, to the possibility of the achievement of this life of peace ripe for contemplation, for all. The possibility of a contemplative life now, with Saint-Just's ideas and with the Revolution, exists as a possibility for all. But the nature of such a life might be different in a society whose fiber is the relations between persons, whose essence and center is these social relations.

One might also ask how it is that the bios theoretikos emerged in Greece. This question leads naturally to the question of what philosophy is. Is philosophy possible in all environments? Did philosophy precede Greek civilization? The answers to these important questions will depend on the definition of philosophy. The inceptual context for philosophy's emergence in Greece is something that can be said to be particular, and yet philosophy has been extended to, and lives on in, different inceptual contexts, despite the many attempts to bring it to an end. ${ }^{14}$ Thus, there is continuity perhaps only in a valuation of philosophy, but not in the idea of what constitutes it, though the latter is always linked to its original constituents, should these be specifiable. 
The question of what made Saint-Just write political philosophy brings the bios theoretikos out of its tradition in a second way, in that it focus it on relations and on the body of a people, rather than on individuals, and, consequently, on communication. Getting back to the social state of human beings means getting back to a state where human beings in a union communicate with one another, but in a situation of equality. In arguing against Rousseau's social contract, Saint-Just states that an act such as an agreement to enter into a social contract could come only when there exists already a complete unity of will: L'acte de vouloir s'unir n'eût jamais pu naître que d'un accord parfait. Il fallait que [les hommes] parlassent, qu'ils s'entendissent..." and, "s'ils parlaient, s'ils entendaient, ils avaient nécessairment communiqué. ${ }^{15}$ So communication in the social state, communication in the sense of political deliberation, was already present and prepolitical, argues Saint-Just. Thus, a focus on relations, as Hegel, Jürgen Habermas, and the very discipline of sociology were to later make central was present in Saint-Just as an outgrowth in part of Rousseau's idea of the general will, the society of which was a society of relations. However, this will for Saint-Just was not hypothetical and late-occurring in the development of human societies, but rather natural and original. Greece and its philosophical development then must be seen as founded in a later stage of human history, when corruption had already occurred. This idea comports with Rousseau's idea that philosophy is not natural. Hannah Arendt is focused on the corruption of the bios theoretikos into the vita contemplativa, and says that Augustine is the first to understand this, and yet whence Greek political philosophy? If we trace its lineage in the revolutionary philosophy of Saint-Just, it is already a corruption.

Speaking about Greek philosophy usually means speaking about Attic philosophy as it was informed and developed by colonials and those who came to Athens or whose philosophies were brought to Athens by others. Saint-Just though, looks partly to Sparta as a 
model for the philosophically based polity, to a city-state that was not considered philosophical. Could a Spartan model then, contain the possibility of a new idea of political philosophy? If Greece was seen to exist for the purpose of supporting philosophers, this vision implied that philosophy was necessarily for the few, if, that is, Athens is taken as the correct, natural, and original environment for contemplation of the philosophic variety. But Sparta brought to all of its citizens not only the actuality of plenty of free time, and even the moral disapprobation of busyness, of that lack of quietude that was seen to be the necessary precondition for philosophy. Saint-Just shows an awareness of the profound results of a difference of conditions, and which beliefs or constructs they lead to, as well as showing his appreciation of the value of the life free from busyness and noise, but the foundation of contemplation may be found elsewhere than in Athens, or even Rome or Jerusalem. It can be found also in Sparta, among "les Indiens" ${ }^{16}$ and, one can reasonably infer, in the peaceful, relational, communicative society which the Revolution, in Saint-Just's eyes, aims to bring about.

The adjoinment of philosophy to what has traditionally been the political, to that which Saint-Just reconfigures as the social, is disdained in the writing of Saint-Just, and yet the writing of Saint-Just stands as traditional political philosophy in some sense. Thus, we have a Saint-Just who disdains philosophy in theory ${ }^{17}$ while using it in practice. The transference of the central element of human community to the social however, turns political philosophy into social philosophy, or social theory, which is itself for Saint-Just the understanding of natural social relations. Thus in Saint-Just the political philosopher is refashioned into a social theorist. The function of the social theorist is the comprehension of natural social relations and the alignment of society to these. The mode of this comprehension and alignment in Saint-Just's total political experience is the mode of revolution, ${ }^{18}$ which then 
must be understood as the de facto mode of political philosophy's (social theory's) existence. Political philosophy as social theory's actualization then can only exist in revolution. The more intimate relationship and correspondence between theory and the actual which SaintJust's life presents as reconstitutive of each such that they form an active dialectic in which neither stands completely apart from the other brings traditional ideas of philosophy with regard to the political more into the realm of the actual, and this actualization of the theoretical moves the de facto nature of Saint-Just's experience into the realm of de jure with regard to the existence of political philosophy, since its definition is altered by this de facto experience such that the concept of the philosophical now has a social action component and thought is no longer the sole province of the conceptual. Put otherwise, the actual mode of political philosophy-as-social theory's occurrence was revolutionary, even if its theoretical employment in the service of the alignment and reestablishment of natural social relations could have occurred as reformist. Philosophy is now in the service of the social and not of the political, and its role is that of correction and purification, or removal of corruption, from natural right. Given that this process of correction and purification always encounters obstacles, a state of exigency, or revolution, is now a necessary element of philosophy in the service of the social. Political philosophy as social theory is in this sense inherently revolutionary.

\section{Utopia}

So-called utopian theory is a type of political philosophy where practice inheres in the theory, since those labeled utopians certainly believed their political-philosophical works to be realizable, and they also worked in practice toward such a realization. ${ }^{19}$ Critiques of such an ideal seem to rely on the mere utterance of the word 'utopia' and its ability to cause an 
immediate, out-of-hand dismissal of any ideal that it is used to describe. Yet utopian theories rarely portended something precise and thoroughly describable in advance, but rather laid forth possibilities that actually tended to have a negating effect on established ways of thinking, and focused on scientific processes that would be capable of reaching a certain end. In fact, many of the socialist utopians of the nineteenth century thought of themselves as scientists. ${ }^{20}$ Attempts to actualize ideals described as utopian were dynamic but exacting processes of adjustment and readjustment, which took place after negotiation with their inceptual circumstances. In this sense Saint-Just is utopian.

The question of utopia is also related to the question of logic. Specifically, it brings up a distinction in inductive logic with regard to political experience. As a movement from the particular to the general, induction as a logical process can proceed from two different categories of the particular. One of these categories is the material circumstances of existence which are without a comprehension of an ideal, a utopia which informs them, and the other is a vision or ideal in relation to which these particulars are understood. In both types these material circumstances are determinative, but in the latter type these circumstances are comprehended relationally and understood as historically emergent and dependent on a material history, and they thus become part of a synthetic historical process. In the former type the circumstances do not form a historically dynamic body of understanding and do not necessarily stand in relation to any temporal or historical movement or progression, but are rather disarticulated by analytic methods of understanding ideas, which methods' ultimate ends are either the attempt to fix a fully circumscribed realm of possible political experience, the adducement of deconstruction as an end in itself, or the construction of culture without a constantly debated telos of the change in historical circumstance and its possible ends (e.g. political philosophy as the demands of the 
bourgeoisie without comprehension of philosophy's existence as such). Utopia can thus serve as both an articulation of dialectical anticipation and inference, and as an element of a logic that is both conscious of historical circumstance and also responsive to it in manner that is not purely passive and observational. The tension between creating and interpreting, between Marx and Hegel, is expressed in the idea of utopia and its absence in a particular historical stage. The relevance of utopian vision remains since Hegel's idea of the end of history as consciousness imputes to consciousness a unity and monodimensionality which can be apposed to, for example, the idea of multiple consciousnesses, while Marx's vision of communism as an end remains, as he said, unknown in its specific content, even as the Marxian idea of communism was not possible without utopians such as Charles Fourier and Pierre-Joseph Proudhon. With regard to its logical connection and aspect then also, the process of theorizing, acting, and adjusting which is Saint-Just's political experience, is utopian, and in the letter of this theory Saint-Just expresses belief in a utopian ideal, in a simple spartan life which would be democratic and organized, but without force or corruption, though this description would not be a full description of his ideal.

A third way in which the concept of utopia is relevant to the study of Saint-Just is as one specific part of the general prescience of Saint-Just in his deprecation of the political. The socialist utopias of the nineteenth century also deprecated the political. ${ }^{21}$ In many areas Saint-Just demonstrates a prescience with regard to future political ideas, even with regard to his deprecation of the political; such deprecation was certainly a tendency of the era of the flourishing of utopian ideas, an era that followed that of Saint-Just. Here again though, Saint-Just can be seen as more radical in his more complete repudiation of the political and, importantly, his doing so expressly and with use of the term itself, whereas the attenuation of the importance and value of the political in later utopias is discernible, though not express. 
Praxis

To discuss the subject matter here in terms of praxis would seem to answer too soon the questions that the political life of Saint-Just presents, and yet the concept is clearly highly relevant to Saint-Just's experience and to the questions asked here, which can be said to be questions of praxis and of the character of the theoretician. There are many different definitions of praxis, but all seem relevant to the character of Saint-Just's work. Since the bare beginnings of a praxis of revolution itself are one of the goals of this exploration, keeping in mind praxis in relation to revolution in particular seems a cogent approach.

Adolfo Sanchez Vazquez attempts to define revolution itself as "creative praxis". ${ }^{22}$

His delimitation of the concept of creative praxis however, distinguishes it from what he calls "reiterative praxis". The concept of reiterative praxis in Vazquez is considered inferior and not revolutionary:

In this form, the unity of the practical process is undermined because the project or end exists in a finished form prior to its realisation. The subjective is presented as a kind of Platonic ideal model which is copied, or duplicated, in the real world. As in Platonic meyaphysics, the model is the determining factor; the real product can be only said to exist to the extent that it approximates to the ideal, and comcomitantly that the failure to adjust itself to the ideal would imply a loss of reality. In creative praxis, the product requires not only a modification of the material, but also of the ideal (or end); the ideal of reiterative praxis, on the other hand, remains immutable throughout, exist already in a completed form which is not affected by the vicissitudes of the practical process. In creative praxis, not only does the material adapt itself to the end or project whose realisation is the object of that praxis, but the ideal itself must adjust to the demands of the material and to the unforeseen changes that occur during the practical process. $^{23}$

However, this idea of reiterative praxis corresponds to Saint-Just's idea of revolution and perhaps to the revolutionary activity he undertook, since Saint-Just was attempting to bring 
France into alignment with its own proper social relations, and this alignment was to an ideal that, although it was the product of historical reflection, remained a theoretical idea to which the country must align, or realign itself. But Vazquez's categories themselves only emerge as possible after the experience of the French Revolution and its effect on Hegel and Marx, among others. Thus there is a seeming anachronism in the application of Vazquez's categories to Saint-Just. However, these categories are helpful in probing the differences between idealist and non-idealist understandings of practice. Saint-Just's historical position keeps the relationship between theory and action tied to an ideal that is informed by history, even as the concept of social relationality and the actual relationships between idealistic theory and action in Saint-Just's political life turn toward and set forth possibilities for future understandings of the relationship which transcend the idea of an alignment with a purely theoretical ideal that is a conglomeration of the political lessons of history, even if this history has not yet taken on the character of the unfolding of contradictions, contradictions which will make Saint-Just's lived experience more comprehensible. It is as if Saint-Just sensed and acted out l'esprit du temps, which esprit is never fully conscious of what it is until its negation creates a framework for its comprehensibility.

\section{Ideology}

Political philosophies that attempt to incorporate practice, or to become inseparable from it, are often described as 'ideologies', and are criticized as such by both right and left. $^{24}$ The end result of an examination of these various criticisms, which are all superficial, is the realization that there is no strict logical separation that can be made between political philosophy and ideology. Attempts to separate the two have only been successful to the 
extent that they have either defined ideology too narrowly or inappropriately (often in accordance with premises that are derived from tendentious thought if not, ironically, from 'ideologies' if one employs the term in the very fashion critiqued here), or to the extent that they have assumed that objective positions from which to analyze concepts such as ideology can themselves be devoid of ideological backgrounds, concepts, conscious or unconscious scholarly directions or directives, and, importantly, that they can be free from the power dynamics inherent in conceptualization. ${ }^{25}$

The denigration of ideology within political science has even comprised a specific counterrevolutionary line with regard to the French Revolution. ${ }^{26}$ This line of critique, primarily by British and American counterrevolutionaries, attempts to demonstrate the insularity and lack of external validity ${ }^{27}$ of French Revolutionary thought, which it labels ideological. One important question that this critique brings up is the question of what external validity means. The French Revolutionaries, and Saint-Just in particular, were known for their great integrity, which could be described as 'internal validity'. However, to what extent were their ideas linked to the reality of the external world? Those who have created this critique of French Revolutionary thought though have fashioned it so that any change brought about could never be significant and rapid without its being labeled ideological in a crude way. To deny the validity of the process by which the Revolutionaries brought about significant change amounts to an insistence that one adhere to former ideologies of political thought which ruled the 'external' world and the range of political possibilities in the mind of traditionalists and reactionaries. The inability of critics of Revolutionary ideas and actions to successfully impugn them with reference to ideology is a result of their inability to distinguish their own conceptual and political frameworks and understandings from ideologies. 
Here, with the assertion of the value of integrity and a turning to a new aspect of the idea of ideology, is presented to political science the question of integrity in relation to ethics. Political theorists theorize the ethical, but have had no real or sustained focus on the kind of thought-practices ${ }^{28}$ which might be said to be necessary in order to be ethical. That is, must ethics as a theoretical subject not be presided over by questions of integrity, that is, of self-referentiality, as first order questions, and ethics as a theoretical subject be presented as a second order set of questions - the substantive content, in a sense, of the procedural 'ethic' of integrity? Thus, integrity might be said to be the metaethic applicable to political philosophers themselves. Could integrity in the sense of consistency of thought and action and action and thought be the precondition of ethicality in politics? Is then contemplation for its own sake ethical? Is the separation of contemplation from other parts of the political ethical?

Saint-Just and many of the other French Revolutionaries, especially those who sat on the Committee of Public Safety during its existence prior to Thermidor, are considered as prototypes for the modern left as it later developed ${ }^{29}$ and their existence as such brings up a question of the difference between strategy and ideology. In any examination of the differences of political opinion on the left in Revolutionary France, one can distinguish between differences in ideals, or political ends, and differences in strategy. Within the latter area of differences would then be found the differences among factions on the left, while within the former would be categorized differences between the right and the left, generally speaking. There are certainly differences in ideals within the camps of right and left as they are widely demarcated in the French Revolution, such as the right's desire for a constitutional monarchy and the left's desire for a popular democracy. The ideal, or end in mind, such as, 
in the case of Saint-Just, the vision of a pastoral communism modeled after Sparta, is one part of ideology, while another is the strategy used to get there. This strategy is theoretical, and is a template for the practical, or for action, so that the components of ideology can be said to correspond to the three phases of Saint-Just's political experience, theory, practice, and exigency, and these correspond to ideal, strategy, and actual action in the realm of ideology.

But is ideology really necessary at all or valuable in any look at the political life of Saint-Just? The answer to this question must circle back to the question of the difference between political philosophy and ideology. Is there really any value for the understanding of political science in the concept of ideology? There does not seem to be a clear separation between the two, but rather only a vague and unsatisfactory conceptualization of ideology and demarcation thereof from political philosophy, often in an effort to undermine the validity of a certain tendency or line of thinking in political philosophy.

To focus on yet another aspect of ideology, to the extent that the understanding of ideology involves the idea of a system of beliefs that are connected intimately to political practice, the term ideology then acquires in Saint-Just and the other French Revolutionaries a new resonance and relevance as a paradigmatic direction. The traditional distance of the political philosopher from the actuality of politics is one vantage point from which to look at the relevant question here. But perhaps this vantage point of the assumption of criticalphilosophical distance is the very conception which must be challenged in its coterminousness with political philosophy. This is precisely one of the things that SaintJust's life as a political person does. It challenges the directionality of theory to action, the nature of political philosophy as purely contemplation and as prior to action, and the nature of experiential knowledge within political philosophy as purely observational rather than 
participatory.

Narrative

The method that Saint-Just's life's work as it is presented to us seems to demand is one which culls the recurrent themes in all types of his work. Yet another, and this is perhaps the most difficult, is to try to present the contradictions in his political philosophy, instead of attempting to choose which antipode was superseded by which other in time. The endeavor to locate his works in a traditional chronological order is certainly a valuable one, and yet the scholar who approaches Saint-Just is presented with so many cautions with regard to the manuscripts and their various, seemingly disorganized and scattered parts that there are many risks of misplacement or misattribution. Perhaps Saint-Just scholarship will have to proceed as Saint-Just did, in a way that was responsive to history i.e. the history that scholarship is creating, for example, in the line from Alfonse Aulard to Anne Quennedey and others, while aware of both Saint-Just's place in a historical dialectic as well as of its own place in that dialectic.

There is also the aspect of Saint-Just that his thinking seems to have progressed rapidly through many stages. Can these stages then be understood to involve revisions, repudiations, usurpations, and supersessions? If so, how does one present a political philosophy of SaintJust? The answer, I think, lies in part in the recognition of the special template which SaintJust's political experience presents us with: that of the constant interplay of thought and action, which creates both a more living and real theory than one normally encounters as political theory, as well as a political action which endorses the value and importance of political philosophy, even as it reimagines its identity.

The problems of dating and sequence that occur for scholars of Saint-Just are then not 
the only area in which the relevance of narration arises. In Saint-Just's ardent attempts to maintain a linear progression of sound political theory as antecedent to political practice, one can see that the problems which confront this ordering of political experience are problems arising from the actual, since for Saint-Just the working out of theoretical contradictions to his ideas was done within his political theory itself (e.g. the critique of Hobbes's and Montesquieu's sociopolitical anthropologies). Obstacles to the correlation of theory and practice then came from the realm of the actual, since Saint-Just's political philosophy is certain in its tone and conclusions, though not without an engagement with political philosophers. The question of narrative then is partly a question of the observation and interpretation of action, and of interpretation of the relationship of theory and action, which necessarily has a temporal aspect. In this temporal aspect narrative becomes an area of questions, and one that arises from the existence of and the focus on the action component of political experience.

In an examination of Saint-Just's theory and action and their relationship, one is presented with the narrowing of the gap between occurrence and recounting in Saint-Just's experience. One can feel as one reads and examines the evidence a pressure that he must have felt; an urgency, and a sense of danger. These sentiments may occur to all of those engaged in work in what is called the political realm, whether that work be philosophy or legislation or analysis or activation and implementation of policies, when such work occurs in emergency circumstances, such as those of revolution as Saint-Just understood it. SaintJust attempts to keep a lineage that proceeds from theory to practice, and this lineage itself is a type of narrative that can be examined metatheoretically. The pressure then comes from the attempt to align theory with action, the urgency from the emergency circumstances which require that social institutions that can guarantee the survival of revolutionary ideals be 
established quickly, and the danger from not only the fact that there are significant obstacles to the establishment thereof, but that the survival of the interim and revolutionary government which is necessary to the establishment of these social instituions is itself threatened with collapse.

Thus, in one sense, it is the attempt to follow the progression of a certain traditional and linear narrative in politics, that of theory or ideal to action, which either creates or abets these conditions of pressure, urgency, and danger. This attempt is one element of a dialectic which honors traditional and idealistic political philosophy even as the results of that political philosophy militate toward a revision of the conception of political philosophy itself, one which favors neither theory nor action, and one which makes neither primary. The attempt to keep the actual social realm as it develops tied to political-philosophical justifications and ideals is the insurance that historical-material conditions of life do not necessarily deny the value of political philosophy, even if a particular political philosophy can be said to find its origins in them. This attempt then in Saint-Just, which is also in some sense a dialectic in the mode of avant-courier between Hegel and Marx, or between idealism and materialism, has logical components that emerge with relation to the concept of narrative which are capable of transcending even this dialectic. The naming of dialectical antipodes itself, as in this apposition of idealism and materialism, creates a pole of narration, but also creates the ground for the transcendence of this dialectic, so that at least within its dialectic aspect, narrative remains dynamic.

As the space narrows between theory and action, such as is necessary in revolutionary conditions, when theoretical references and justifications and the political-philosophical foundations of, for example, social institutions, must be summoned, rethought, adjusted, and established quickly, the possibility of ponderousness tends toward disappearance, and thus 
the notion of the formulation of sociopolitical ideas through contemplation along with the lineage that forms the traditional narrative of idealistic philosophy, disappears. The retention of political philosophy in its traditional form by Saint-Just is thus in some sense his intention, but it is overtaken by his action, in the sense that political actions in exigent circumstances demanded that theory move much closer to the action, sometimes merging with action, sometimes necessitating the prioritization of even immediate action, which in turn can become the ground of new theory but also has in fact become the ground for metatheory, or questions about our understanding of what theory is, questions which involve narrative because metatheory is distinguished from theory partly by the objectification of theory by the placing of emphasis on theory's occurence in time, on its temporality, and further by the understanding that narration is the attempt to communicate, think, and articulate time.

One of Saint-Just's primary functions is that of political philosopher, but political philosopher in a new guise, that of one who cognizes historical movements which, in the discourse of natural right in which Saint-Just partially remains, ${ }^{30}$ occur as degenerations, or more generally speaking, as disalignments: "La tyrannie déprave tout l'homme, et par une longue altération le rend à ses propres yeux incapable du bien. Otez la tyrannie du monde, vous y rétablirez la paix et la vertu." 31 As discussed further on, the role of the political philosopher that is reflected back to us from Saint-Just's words is partly that of narrator of history, this narrative being essentially bound up with recognition of disalignments to social right.

Logic

Is there a correspondence between the relationships of logic and the relationship of theory and action? Specifically, is there a dual correspondence between induction and the 
movement from action to theory, and between deduction and the movement from theory to practice? Such a relationship would seem to involve consideration of whether or not action is more particular than theory. John Grier Hibben speaks to this question in his correlation of induction with the actual:

The impression is too often left in the minds of those who have pursued the study of deductive logic exclusively that the formal laws of the syllogism constitute the entire body of logical doctrine and that reasoning consists solely in drawing conclusions from given premises. There is danger here lest reasoning become associated with an artificial procedure that seems to find its proper sphere in the solution of verbal quibbles and logical puzzles..... In the actual experiences of life, we do not find our premises ready made....we meet particular facts before we do the general laws. ${ }^{32}$

One can view the political life of Saint-Just, his acuality, in its bringing action, practice, and the particular closer to the heart of thought, as a necessary corrective to centuries of predominance of syllogistic logic. But given that Saint-Just's political life calls into question the relationship between theory and action, especially in its directionality aspect, one might ask whether or not, if there is so much interplay between the theoretical and the active, it is valuable to talk about directionality at all? That is, if politics is properly speaking, a situation where theory is determinative of action while action, often counteraction, is simultaneously determinative of theory - if politics is this bidirectional interplay, at what point does directionality evanesce within the analytic? This is a question that is inherent in Hegel's philosophy. One sees in Saint-Just's life a testament to the validity of Hegel's later idea of dialectics and his idea of spirit as applied to history. In Saint-Just's political life, the relation between theory and action is such that both theory and action each serve as catalytics for the other, and it may even be that a constant dialectic of this sort is a better description of politics than the idea of action following theory or theory based on participatory experience, yet all seem to interrelate with one another. 
Political philosophies have rested on basic philosophical ideas about experience, which is not the same thing as practice or action, which would be related thereto. More precisely, actual direct experience of the type of Saint-Just the political philosopher is part of a continuum within experiential knowledge from observational experience, as in empiricism, to participatory experience. For political philosophy, observational experience has largely taken over the entire category of experiential political knowledge:

\section{Diagram 1}

Spectra of Experiential Political Knowledge

Theoretical Method: $\quad$ deduction $\longleftarrow \longrightarrow$ induction

Character Involved: $\quad$ theorist $\longleftrightarrow \longrightarrow$ actor

Type:

observational $\longleftarrow \longrightarrow$ participatory

Role of Character: $\quad$ spectator $\longleftrightarrow \longrightarrow$ participant

Can objectivity then, the objectivity required by science and valued by academia, reside wholly in the observational? What, if anything, of value is lost in an assessment removed from experience? The question might better be put differently so that any study of 
something might be said to require not only disinterested observers in its full assessment, but also the views of those who have participated in the event observed, or those who are, or have been, the thing observed.

But what about with regard to the political realm itself? Much of what had been the contemplative life is now, especially in America ${ }^{33}$, able to exist with normative legitimacy only within the academy. This fracturing of a more complete being which the acquiescence to injustice that is a mainstay of academia requires, creates what has been referred to as a 'fractured radical subject', ${ }^{34}$ that is, a subject considered radical by her or his refusal to abide injustice, which is what disinterestedness of philosophy apparently requires, at least in its current academic guise. Referring to Alexandre Kojève's master-slave dialectic, Joy James and Edmund T. Gordon describe part of this situation thusly:

Despite its political limitations, the fractured self of the radical subject desires what the academy cannot provide: relevancy and accountability to collectivities resisting domination. The radical subject rejects the arena provided by the academy to perform as center-stage spectacle or sideshow attraction. The desire for recognition and legitimization in a context other than that built by the academy is what fractures and pushes the radical subject outside, off stage. Radical subjects seeking activism outside the academy do not try to create a space inside as a final destination point or as an identity marker for radicalism. ${ }^{35}$

The thinking of James and Gordon is valuable for articulating some elements of the possibility of a revolutionary subject, this subject being a result of the circumstance that the vita contemplativa now exists predominantly under the auspices of the academy, especially in the United States. While it was more common in the time of Saint-Just to contemplate politics outside of the academy, it was less common or previously unheard of to embody the three roles of political philosopher, statesman, and revolutionary. Thus, in the case of SaintJust we have with regard to modern academia: 


\section{'Radical Subject'}

Thinker/Revolutionary

\section{Traditional Subject}

Statesman

Aside from the fact that Saint-Just's political theory radicalizes the idea of 'governor', perhaps Saint-Just's life as a political experience also radicalizes even the role of 'statesman', in the sense that it can take us back to the root of this role and to an examination of the role of 'governor' by instantiating a political subjectivity that is ideally a combination of these roles, the practice of which is mutually mediative and simultaneous, the existence of this revolutionary subject then containing the possibility of political philosophy's extrication from the academy, and also the possibility that the realm of the vita contemplativa, was always and already democratic, and that its root, the bios ethikos, was communicative. Rooting the activity of political philosophy in active democratic participation would seem then to diminish the anti-participatory bias of deductive logical outgrowths, such as might describe academicized political philosophy. The 'distancing from the fray' of academic disinterestedness can also then be seen to have as its class component petit bourgeois abstraction, ${ }^{36}$ a result of the conflation of the experiential with the observational.

Foundation

'Foundation' is relevant as a category of consideration of Saint-Just's sociopolitical experience in that foundational political action can be distinguished from political action that is simply political action in an established polity or society. ${ }^{37}$ The distinction can be put as a question for political experience, and that question, which is one further aspect of the 
examination of the space between ideas and the actual, is the question of whether or not there might be an important difference between this space when it exists in a context of foundation versus when it exists in an established and stable political context. Saint-Just's experience as a political actor and theorist occurred in the former context, though the ghost of the latter existed as a theory of practice as it should be in an established polity.

It is striking that in Saint-Just the drawing on the body of political-philosophical reflection with regard to foundation ${ }^{38}$ results in a foundational politics that is synonymous with revolutionary action. Here then the active and rapid change of government overtakes the entire category of foundation, and in some sense obviates consideration of its nonrevolutionary aspect, an aspect of foundation on which Arendt had already cast aspersions because of its inimicality to proper understandings of the Roman political experience $^{39}$. Whether or not a proper understanding of Roman politics and political thought would have been conducive to an earlier development of specifically revolutionary thought historically speaking, which idea seems to be both present in Arendt's thought and anachronistic with regard to the historical conditions which would make a revolutionary focus possible, the coterminousness of questions of foundation and questions of revolution in the experience of Saint-Just reorients the focus on foundation somewhat away from both reformism, or the change of fundamental elements of a polity through channels prescribed by the very system that one wants to change, and also away from the idea of political philosophy as quiet reflection antecedent to foundation. The reasons why Saint-Just's experience does this are first, because revolutionary action itself becomes substantively informative for political thought itself and questions the temporal relationships between theory and action, and second, because for Saint-Just the work of political philosophy becomes the work of historical consciousness, the consciousness of proper social relations which are both prior to 
and superior to the political. 


\section{THEORY}

The Right of Practice

Political Philosophy

Is Saint-Just a political philosopher? Perhaps he is one in the traditional sense but he is also one in a new sense, one more defined by action and by actualization. This state of being "also", that is, the integration of one and of another, this state itself, is Saint-Just. Saint-Just would be far from the only theorist to, qua political philosopher, reject philosophy. In fact, a devaluation of philosophy is now almost a hallmark of political theory. It exists sometimes as an express desire of a body of theory, as in Marx's philosophy, and often also as an underlying portent, as in postmodern theory, feminism, and in Kantian philosophy. Therefore, one cannot so easily diminish Saint-Just as a philosopher based on his disvaluation of political philosophy, as the work of both Liénard and Soboul tends to do ${ }^{40}$ and as Saint-Just's own words might tempt one to do. Saint-Just calls philosophy itself a corruption, when it is understood in relation to society, which is of prior importance, ${ }^{41}$ and yet Saint-Just theorized, and his statements are very often put in general, political philosophical terms, even when they are speaking to specific actions. The beginning of his speech to the National Assembly regarding the Constitution of Year I brings the whole world into the philosophical discourse and contemplation of liberty, a philosophical discourse engendered by action: “.....aujourd'hui....par un destin plus doux, vous méditez la liberté du monde, les peuples, qui sont les véritables grands de la terre, vont vous contempler à leur tour." thought of as political philosophers, including Solon, the Gracchi, Gabriel Bonnot de Mably, 
Numa, Lycurgus, and Maximilien Robespierre, the most significant influence on Saint-Just's ideas was Rousseau. ${ }^{43}$ Rousseau inspired the actors of the French Revolution profoundly, and in the development of the French Republic under Saint-Just and the other revolutionaries, the concepts of the general will and the idea of a natural, harmonious state of human existence prior to historical civilization are perhaps the most significant philosophically.

In a close study of Saint-Just's main written works, L'Esprit de la Révolution, Du Droit Social, and Fragments $d^{\prime}$ Institutions Républicaines, the concepts of the natural, the social, the political, and the civil emerge as central, and they are the concepts through which this work examines Saint-Just with regard to the questions about the relationship of theory and action and with regard to the question of the content of revolution. Other concepts that figure prominently in Saint-Just's work all relate back to these concepts. Thus, the study presented here has a conceptual architecture, but it should be remembered that Saint-Just himself was not conceptually focused and does not ever discuss ideas conceptually, linguistically, or etymologically, as such conceptual examinations as approaches to politics and to knowledge in general were rare until middle of the nineteenth century. While a conceptual approach is taken, I have refused specific new definitions for the central concepts in order to avoid analysis and to abet a synthetic approach, which considers the dynamism of concepts historically, the novelty of Saint-Just's experience and the refraction of traditional concepts through this experience, and which allows for further scholarship to help fill in the content of Saint-Just's historical moment and experience, and which tries to build new concepts, or new senses of concepts, rather than analyzing existing ones. As a beginning point though, and for the most part, the various central concepts can be understood in one or more of their conventional senses. Thus, the 'social' herein comprises the senses of 'forming or having a 
tendency to form cooperative and interdependent relationships with one's fellows', 'of or relating to the interaction of the individual and the group', 'of, relating to, or concerned with the welfare of human beings as members of society', and 'of or relating to an association, partnership, or corporation'. The 'civil' has the senses of 'relating to, growing out of, or involving the relations of citizens one with another or with the body politic or organized state or its divisions and departments', 'concerned with or pertinent to internal affairs of a state or its citizenry in contrast to external affairs', and 'living in or exhibiting a condition of social advancement marked by organization and stability of community life or government'. The 'natural' has the sense of 'of or relating to a creative and controlling agent, force, or principle operating in something and determining wholly or chiefly its constitution, development, and well-being, or, of or relating to such a force or agency in the universe acting as a creative guiding intelligence, and of 'of or related to a set of principles held to be established for the regulation of the universe or observed in its operation. ${ }^{44}$

The 'political' in Saint-Just is, however, transmogrified, transferred, and reduced in value, relevance, and importance such that using a traditional definition as a baseline will not do even intially. The 'political' for Saint-Just is the area of the external affairs of a society, but these external affairs are considered dangerous and potentially usurpative of the social realm, and the 'political' is virtually always regarded and understood from the perspective of the social realm, that is, from the inside looking out. Clarification of the relationship between the political and other concepts is made then partly by the introduction of the ideas of the au-dedans and the au-dehors. Saint-Just actually uses these terms, however, he does not give them focus as concepts. The definition of the political then necessarily calls into question the particulars of the internal and external worlds in relation to other elements of the traditional conceptual framework for politics, concepts such as 'the state', 'a people', and 
'sovereignty'. Ultimately, we cannot begin with an operative definition of 'the political', and not doing so comports well with the idea that Saint-Just's political experience and what can be learned from it can help to understand a historically developing redefinition of politics.

\section{The Concept of The Natural}

There is a historical continuum of understandings and uses of the concept of nature, and Saint-Just occupies a particular historical position on this continuum. Saint-Just exists in time and space as, inter alia, a champion of the Enlightenment and its valuations and understandings, even if he did not see the term 'Enlightenment' employed as it is now. The Enlightenment thinkers of France began their ideologies with the concept of nature because they were responsive to and respectful of a tradition of political philosophy which had nature as one of its important and central concepts. ${ }^{45}$ The concept of nature has been central for many political philosophies throughout history. But for all that, it may arguably be a false concept.

Of the thinkers of the Enlightenment, Rousseau is one of the foremost influences on Saint-Just, and his influence is evident in express statements by Saint-Just, in the general vocabulary and language of Saint-Just, and in the importance and understanding of the concepts Saint-Just uses, including the concept of nature. There is a tendency from many directions to diminish the idea of Saint-Just as someone who produced any serious political philosophy in his own right, ${ }^{46}$ and one way to begin to challenge this belief is to compare Saint-Just's ideas to those of Rousseau, from whom both he and the French Revolution drew 
inspiration and ideas. Such a comparison shows that Saint-Just cannot be written off as mere imitator or implementer of the ideas of another philosopher, though elements of the thought of Rousseau, Montesquieu, and Lycurgus, among others, are found in his work. Such a comparison is presented here below with regard to the concept of nature, a central and original concept in the work and in the ideas of Saint-Just.

In the work of Rousseau, one sees nature occupying an uncertain and contradictory role with regard to human beings. Therein, human beings are somehow ultimately both natural beings and somewhat 'denatured' beings. In general, one sees time and again in political philosophies which use nature as a base or standard, the irresolution of the natural with regard to human beings. In political philosophy, human beings are considered the only entities in the universe capable of acting against nature, or of becoming distanced from it, and thus nature as a standard becomes necessarily ontological. Yet the standard as a concept is equivocal in its ontological import. Are human beings capable of being unnatural in their being or not? The question often proceeds to the question of action - to the question of natural or unnatural actions or behaviors, or degrees of distance from accord with nature, and this brings up the question of the content of 'being', with being sometimes defined by actions (e.g. Aristotle's understanding of a thing by understanding what it does). This is not the place for a full examination of these questions, but the important point here is that there is an uncertainty about the possibility of human beings being in discord with nature, and this shows up in the convolutions of Rousseau's thought as he attempts to keep an accord with nature while at the same time positing a historical trajectory that is built on the idea of a divergence from nature which occurred in history. A comparison of the relevant conceptual terrain in Rousseau and Saint-Just is helpful for comparison and contrast. Schematic I shows this terrain in Rousseau. Schematic 2 shows these same concepts in the thought of Saint-Just. 


\section{$\underline{\text { Schematic I }}$}

\section{Rousseau}

The Story of the Political

\section{A Natural Progression to the Unnatural}

$\underline{\text { Natural }}$

Liberty

Relative Homogeneity of Persons

Equality

Possession

Health

Instinct

Action Without Morality
Social/ Civil

(founded on esoteric knowledge)

Relative Heterogeneity of Persons

Inequality

Property

Illness

Reason

Morality

In a close reading of Rousseau, one notices that Rousseau seems to discuss and view the political in two ways. On the one hand, he takes it as the general subject matter on which 
he is writing, and describes a progression of human life and history with regard to this idea of the political that is somehow both natural and unnatural. This progression taken altogether is then an overview and description of the political, and is anthropological and historical. On the other hand, Rousseau seems to have a view of the political in which it only exists after a certain amount of this stated progression has occurred. Would nature, in Rousseau's philosophy, be better described as prepolitical or as protopolitical? The question seems that it might be important. If there are no elements of the political in nature, then the political must be a product, or byproduct, or effect, that occurs during a historical human progression, and nature might be described as prepolitical. Or, is it that nature is "protopolitical"? There is in Rousseau the tendency to describe the progression itself as natural ${ }^{47}$, and thus in this sense "protopolitical" makes more sense. Saint-Just seems to place the political entirely outside the realm of nature, thus forming a bridge, or intermediate step, between those political philosophers who made significant use of the concept of nature in their political philosophies and those such as the philosophers of the German Enlightenment who dispensed with nature rather altogether as an important basis for political and ontological understanding.

Instrumentalities of nature in Rousseau have their results in a consciousness of nature's increasing use as a standard, even as its importance per se, that is, in terms of its particular conceptual content diminishes historically. Oxymoronically, Rousseau's use of nature in the Discourses implicates nature as an agent or force in the very movement away from itself, while in the Considérations sur le gouvernement de Pologne, nature is barely mentioned expressly, especially in its guise as foundation of natural law. When it is mentioned as such, it is as instrument for practical considerations of government. ${ }^{48}$ The equivocation in Rousseau with regard to nature is corollary to his "[undercutting of] the sharp traditional distinction between strictly theoretical and strictly practical writings". ${ }^{49}$ Rousseau states that 
nature was not a preparation for society, and yet the progression toward society is described as a natural progression. Thus it seems that in Rousseau there might be a dialectic between two different conceptions of nature as well. On the one hand, nature as a basis and temporal antecedent, and on the other, nature as a sort of force of a movement that is at least likely, if not inevitable. Could nature rightly be both, though, or is not some further distinction in order? Is Rousseau then here also starting to break away from nature as a basis for the political, with Saint-Just carrying this break a bit further?

Rousseau's philosophy of the understanding, as it is laid forth in Schematic I herein, would have within its own process, for at least part of it is expressly described as a process, some elements natural and others unnatural - namely, needs received from nature and "needs to which circumstances have subjected us". These circumstances, in Rousseau's philosophy of the understanding then, would they be outside of nature fully, partly, or not at all? Again at this level and in this area one might pose the question of how it is that nature can exist in both ways in Rousseau's philosophy? That is, can unnatural elements of the understanding or of human relations come about through a sort of natural progression? It is then as if Rousseau anticipates the internal contradictions of later Hegelian philosophy, but inexpressly.

An interesting question that arises in looking at Schematic 1 above is whether or not the natural and unnatural separation which is manifest at a relatively early stage of the process of the understanding is maintained or manifested throughout the process, and in its end. Through Rousseau's description of the process of human knowledge in the Discourse on the Origins of Inequality, one can at least infer that the understanding is perhaps the natural branch of a twofold knowledge whose counterpart is reason, and that reason is the unnatural branch of human understanding.

Rousseau's description of the understanding includes a two-way relation between needs 
and the passions. Rousseau says that needs are the origins of the passions, but also that the passions "porte les humains à ces besoins [eux-mêmes"]. ${ }^{50}$ The relationship then is circular here. Regarding the passions, Rousseau keeps a division in these between those natural and those not natural, saying that "a multitude of passions are the product of society," describing one natural passion, pity, as important in its being the source of all social virtue.

Part of the process of consciousness in Rousseau is a filtration of needs through passions. The passions filter our needs, and this is a part of the process of consciousness which leads to understanding and reason. So, here at this level of the overall process of the understanding the distinction between the natural and what is not natural still holds. This then would be further evidence that any distinction between the understanding and reason might hold this prior distinction.

If reason is from society, yet Rousseau uses reason to deduce from nature, in the end a circle of rationality, or paradox of sorts, is created. Reason is impugned by Rousseau, and attempts to see nature through its lens as well. And yet, by what means does Rousseau create his descriptions and make his deductions? Here one might argue that there are both natural and unnatural elements in human knowledge, and that one can attempt to see through the later and less natural parts of this knowledge. But who would be best equipped to do this? A philosopher perhaps? No. Rousseau says that philosophy is unnatural. Thus one would have to consider a philosopher less likely to be able to arrive at any sound conclusions about nature and the political than other persons. Is the only way out of this dilemma of Rousseau's insights, deductions and inferences as a philosopher having so much value while at the same time they are impugned by his own descriptions to see Rousseau as creating a new conception of political philosophy, on which Saint-Just is reliant?

So here again, one sees rather clearly the maintenance of elements of the natural 
throughout both the processes of the understanding and of human society, and it seems that there is no decisive break in Rousseau's philosophy. Pity is the connection to nature in the realm of the virtues, but it is social, that is, of society, which in some senses is postnatural. Here still one can go back to the question of whether nature is an original condition or state that is slowly attenuated in humankind's progression or whether nature is an overall process within which there are somehow found to be unnatural elements. Both seem less than clear. Saint-Just, again, takes the former approach, though not in a simplistic way (See Schematic 2).

There are also subtle differences between Rousseau's explication of government and its origins and that of Saint-Just. For Rousseau, force seems to be unnatural and undesirable, and yet somehow at the same time present in societies, which idea brings back the problem in Rousseau's thought that is his equivocal position on nature. Rousseau separates subsequent "circumstances" and "developments" from a state of nature, and yet these circumstances and developments emerge as pivotal in relation to societies historically. Thus, the question of just how it is that circumstances and developments arise. Do they arise out of nature but yet are not natural? If not, what is their origin, and does this separate origin have some or all of its origins in nature, respectively? This question can also be said to be that of how convention can arise from a natural state and then take on an important role in political and social history in contradistinction to nature, or equally as what exactly human perfectibility is and whence this "faculty". 52 
Schematic 2

The Natural in Saint-Just

Nature

(Legitimate)

Equality

Natural Morality

(Sentiments of the Soul, Penchants)

(Filial Piety, Love, Friendship)
Convention

(Illegitimate)

Force

Unnatural Morality

(Fear, Chivalry, Familiarity)

Passions

$\underline{\text { Social }}$

Civil

Political

Relations

Relations

Relations

Between

Between

Between

Individuals

Needs

Peoples

Laws

War

Savagery

Property

Possession

Class

Founded on

Founded on

Inequality

Independence

Equality

Isolation 
This same equivocation about nature does exist in Saint-Just, but Saint-Just is more thoroughgoing in his trust in nature as the concordance of society, at least with regard to force. Force is that which is to be eliminated entirely from the life of society, and Saint-Just rejects Rousseau's conjectural anthropology insofar as it legitimizes force. To Saint-Just the locus of force in Rousseau is the social contract; the concept of the social contract is inherently a concept from the realm of power and force:

ce que nous appelons contrat social n'est ....qu'un contrat politique.......les hommes dans l'état de nature menaient la vie sociale, leur principe était l'amour; dans la vie politique, les hommes mènent la vie sauvage, leur principe est la force. ${ }^{53}$

The social contract is the product of convention, not of nature, and Saint-Just writes that, paradoxically, the social contract could only emerge in a society when the conditions which would obviate it are already present. ${ }^{54}$ Put another way, the preconditions for a Rousseauian social contract render its emergence or adoption superfluous. Thus the social contract is an errant superfluity, but one understandably produced when political relations are mistaken for social relations. For Saint-Just nature and the social are always and already with us at some level. They are available to us again through revolution, and through the discernment and creativity of the legislator as the new political philosopher. ${ }^{55}$

For Saint-Just the historical problem for a foundational political philosophy is this separation of the "magistrates from the sovereign." The sovereign, for Saint-Just, is never other than the people, and, importantly, he never uses the term sovereign to refer to anything other than the people. He otherwise also uses the term "prince" instead of "magistrate", but the problem is consistently that this separation of the magistrate or prince from the people's authority has occurred historically. Rousseau, for whom the identity of the sovereign with the people is raised as a possibility, accepts the existence of force in societies and makes an 
ex post facto attempt to displace traditional force onto the "will of all" and then to dissolve it eventually by the operation of the general will. Saint-Just rejects not the ideas of the will of all and general will but rather again the contractual basis for society, and more basically, Rousseau's proffer of a conjectural contractual basis for society, preferring to rest on actuality:

" On dira peut-être comment un peuple subsistera-t-il sans contrat, je demanderai quel peuple en a un." 56

The confusion of the political with the social then, which idea is a central idea of Saint-Just's theory of the history of society, refutes the social contract: " ...la république, par la nature de la convention, a fait un contrat politique, ou de force, entre chacun et tous et ce contrat politique form un pacte social...." ${ }^{57}$ but, for Saint-Just, nature is rather a force which governs the relations between the social law and the civil law, and the former is that on which societies are founded.. Society is really something more like nature in the conventional sense, in that it is not of man's development. However mankind comes to exist, its beginnings are always and already social: "la société n'est point l'ouvrage de l'homme". 58 Saint-Just does not then place as much emphasis on the historical aspects of nature. The corruptions which arise to lead humankind away from an alignment with natural law, viz. preeminently, the displacement of the political domain onto the social, are accordingly not well spelled out in the work of Saint-Just. ${ }^{59}$ Thus Saint-Just avoids a precise social anthropology, the type of which ties Rousseau's political theory more significantly to a toospecific historical trajectory even as it allows for his general will theory. For Saint-Just nature and the natural law are right there in our grasp, and the Revolution can reconnect society to them.

There is then no need for the position of a state of nature in Saint-Just. There was, however, a historical point or period during which the people "perdirent leur gout des 
assemblees" and the political entered falsely into the domain of the social, but such a historical event occurring over time is in the work of Saint-Just not a part of a specified historical trajectory. ${ }^{60}$ One of the goals of the Revolution must then be to realign the social with the natural. This element of Saint-Just's work begs the question of whether or not the revolution could be achieved in the same way elsewhere, the particular elements of the social being created by the legislator in accordance not so much with natural particularity in a given society, but rather in accordance with a natural propensity for social, intraspecies harmony in general.

When considering the theoretical work of Saint-Just, one wonders whether or not nature is really necessary, because the idea of the social already has the sense of harmonious relation and cooperation which state of nature theories impute to a natural state. Perhaps if Saint-Just would have been able to further reflect and elaborate on the social, he would have moved toward dropping nature from a temporal account of humans living together. Nature seems to serve, in Rousseau and Saint-Just, as an a priori or baseline. And yet, in both thinkers' accounts of it one detects an uncertainty about what it is and even also the possible superfluousness of the concept. Was this anticipatory? The Enlightenment's manifestation in German thought soon did away with nature, and probably uncoincidentally with the a priori as it had been used and understood, thus doing away with a temporally fixed baseline altogether and thus opening the way to thought that was less analytical. Saint-Just is a link between Rousseau and Kant, between the reliance in Rousseau of an already not unproblematic concept of the natural, and the critical mode of philosophy largely inaugurated by Kant, a mode which, in its epistemology, deemphasized nature. ${ }^{61}$ This kind of view of Saint-Just's concepts is Hegelian, in that it itself sees a historical progression in which 
concepts like nature do become in a sense superfluous They become so in process of the actualization of their negation in a dialectical-historical movement.. In Hegelian terms, the negation of nature was inherent within the concept itself and the motion or process of negation is historical.

Is nature then ultimately unnecessary as an a priori for thinking about what has been known as 'the political'? Is any a priori necessary? Perhaps it is not so much the case that no a priori is necessary as it is the case that theory does not have to begin here, or, more precisely, theory does not have to begin with theoretical truths or concepts at all. In examining the relationship of political thought to action, one might ask the question whether action that is not referential to theory is more likely to produce changes in the way people live than is action that is referential to theory? Or, to put it the other way, is theory that does not bring about or that is not capable of bringing about actual changes in the way people live properly considered political theory? Or, again, is theory in a proper sense created $a$ posteriori, with relation to political action? The prejudice which most political theory carries with it, the prejudice that theory comes before action, connects to the broad and sustained influence of understandings of theory and practice that relied on deduction as opposed to induction, insofar as the idea of movement from the actual (or the actualized) to theory carries within it the idea of movement from the particular to the general, while the idea of movement from theory to action carries within it the idea of movement from the general to the particular. The questioning of the a priori as a foundation for political philosophies is also a questioning of the fixity of their fundament.

Rousseau moves nature somewhat out of its fixity as an a priori element of political philosophy by moving the idea of nature somewhat into a historical framework via the idea of the state of nature, and Rousseau and Montesquieu take up Hobbes's theory that there was 
such a state of nature and that in it men were equal. Rousseau adds to nature's state of equality of human beings the happy attribute of harmoniousness, which also does Saint-Just, but Saint Just goes back to Hobbes's description of timidity and makes an emendation thereto. Hobbes sees nature as both something prior and as something temporal, that is, there is an inevitable progression of society that is natural, even as it moves away from the state of nature. In this natural movement away from the state of nature, diffidence arises from natural equality. Both Rousseau and Montesquieu pick up this diffidence, or timidity, of human beings in a natural state, as does Saint Just in turn. But, whereas Rousseau and Montesquieu present an anthropology which merely relies on this timidity of "natural man", saying that human beings in a state of nature, upon encountering one another, flee, ${ }^{62}$ Saint Just makes a distinction in this area of natural timidity between intraspecies behavior and interspecies behavior, a distinction which corresponds to the distinction he makes between the social and the political. Saint Just's refinement of Rousseau and Hobbes is then that "natural man" is diffident and flees only when encountering others who are not of his own species, but that natural man did not flee on encountering those of his own species. The differentiation of interspecies from intraspecies behavior develops an ontological basis for Saint-Just's unique distinction between the political and the social, even as it follows some parts of the approach of state of nature anthropology. The social realm's existence as a realm of the intraspecies relations of mutual affection is parallel to the political realm's existence as the realm of interspecies existence, the realm of the relations of force.

Saint-Just understands nature partly within the conceptual framework of the idea of the 'state of nature'. For Saint-Just, there is a hierarchy of correctness in the state of nature philosophers, with Hobbes being significantly incorrect in his assertion that the human being in the state of nature was intrepid and aggressive, and Montesquieu being more correct in his 
assertions that the human being in the state of nature was timid. But Saint-Just's emendation to Montesquieu consists not only in the elaboration of Montesquieu's idea of natural man by specifying the particularities of his fleeing from others, as discussed above. The correction to Montesquieu's adducements also has a temporal component. That is, both Hobbes and Montesquieu have their history backwards, taking it as they do that the savage state of man and his lack of a society came first. Saint-Just argues that there was society in the state of nature, and that it was not 'savage': “Les hommes dans cet état n'étaient donc ni stupides, ni sauvages; le rapport, le plaisir les unissait donc, ils ne se faisaient donc pas trembler et fuir." ${ }^{\circ 3}$ And Rousseau, who is perhaps most correct in his belief in a happy natural state, still falls short as well, in that the social contract implies a society wont to conduct itself in a manner that would only be possible at a later time, after the usurpation of the social by the political. Thus Rousseau has his conjectural developments out of order as well in some sense:" Si tel est l'objet du contrat social de conserver l'association des hommes dans ce sens sont considérés comme des bêtes sauvages qu'il a fallu dompter..."64 Saint-Just does not even want to use the word 'savage' to describe natural man, a natural man who is also originally a societal man. In fact, he reverses this, calling the man of the corrupted civil society that has developed through the loss of the natural and social a savage.

The idea of a state of nature as an antecedent to the political good appears in Saint-Just then only insofar as it needs refutation, that is, negatively. Positively, the idea of nature in Saint-Just occurs otherwise, and has within it elements of the Rousseauian conception, sans the idea of the state of nature. Nature in Saint-Just, as in Rousseau, serves as a universal force with which human beings can either be aligned, or in accordance, or with which they can be not aligned, and not in accordance. The unnatural may be said to exist also for SaintJust in the sense that a proper ordering of relations is natural, and so an improper ordering, 
such as would occur in the misappropriation of relations between peoples to relations between persons, would be unnatural. But in this understanding, nature has no necessary or perennial content, but it is rather a proper ordering of relations, whatever their content, which is natural. Thus, Saint-Just realizes that his specific jurisprudential adducements are proper to the France of his time, while those of Lycurgus were appropriate to the Spartans, though there is certainly a drawing from Sparta ideals in the specific institutions that Saint-Just sets forth. $^{65}$

At times Saint-Just equates both the social state and independence with nature. Independence is fundamental for Saint-Just as the social state is founded on it, and Saint-Just calls it first a "rule" ${ }^{66}$ and then a "law of nature" ${ }^{167}$. Thus, an elucidation of Saint-Just's idea of independence is part of the explanation of his view of nature. Saint-Just calls both independence and preservation laws of nature, but makes independence prior to preservation, with preservation reliant on independence. Independence as a law of nature is really the integrity of respective rights. ${ }^{68}$ As a law, this must mean that this integrity is a natural, or original element of society, and further that maintenance of this social integrity is an imperative drawn from nature. Any one's independence must ensure the independence of all. ${ }^{69}$ Love as elemental in natural social relations is also related to independence. Saint-Just states that a former state of natural independence, a state which preceded the current savage state of human society, was love itself, but love is also prior to independence and creates it. ${ }^{70}$ In the natural social state of harmonious relations, human beings are part of their species and also individuated beings, and it is in this mode of duality that independence occurs in the social realm. However, beyond the natural social state, society is a corruption from this natural social independence, which Saint-Just describes as moral. The current social realm is a corruption, since human beings in society turned away from their natural social 
independence and instead toward an independence modeled on and imitative of an exteriority, on what is, in relation to natural social harmony, an extraneity. This extraneity is the independence of peoples from peoples, which became the model for the relations between persons. This misplacement, which forms the political, transferred security from its original and natural inherence in independence to a perceived inherence in mutual annihilation. ${ }^{71}$

In Saint-Justian theory, nature's portion is in the au-dedans. In the work of Saint-Just the au-dedans is the locus of the natural and of the social, and it is distinguished from the audehors, from that which is foreign to or inimical to social harmony and the natural and original social state, from the locus of the political and the corrupted civil state. The movement back to nature, achieved for Saint-Just by revolution, is a drawing inward to a circle of security, to an inner sanctum which keeps evil out. Evil for Saint-Just is discord and disharmony. In reading Saint-Just's words, there is a touching and palpable sense in SaintJust of a yearning for goodness and purity, and for the creation of a gentle and tender space of love and mutual kindness in a within, inside a circle which closes itself off from forces which create disharmony. In this movement into the au-dedans which was the motive of SaintJust's political life, one moves from the political world back through corrupted civil and social worlds to nature. ${ }^{72}$ For Saint-Just, revolution is in the service of nature. 


\section{Schematic 3}

The Realms of the Au-Dedans and the Au-Dehors

$\underline{\text { Au-Dedans }}$

Natural

Social

Civil 1 $\underline{\text { Au-Dehors }}$

\section{Civil 2}

\section{Political}

Independence, or nature, can also be defined in terms of right: it is right between persons. Possession is right between citizens. Force is right between peoples. Independence guarantees that force is kept out of the city, and is a unifying force in the au-dedans. Thus, in the Saint-Justian view of nature, there are levels and relations of right. These levels of right, right between persons, right between citizens, and right between peoples, show that right is here placed partly outside of nature. ${ }^{73}$ Nature is clearly not a part of or foundation of the political, and yet there are proper relationships between groupings of relations. The relations between peoples have no place in the social state, and in fact their misplacement there becomes the basic idea of Saint-Just's sociopolitical, anthropological history. But one sees that the tradition of right is concerned with just these kinds of levels or areas of relations and, in turn, in their proper relation to one another, and this tradition places right firmly within nature. The separation of the political from the natural, and, more fundamentally, the separation of the certain relationships of right from nature even while nature is still used as a 
basis and origin (an origin to which to return) places Saint-Just in between naturalism and a developing obviation of nature. Miguel Abensour states that "On ne peut reprocher a SaintJust de ne pas avoir compris le rationalisme de Rousseau qui n'est pas celui des rationalistes (ne fallait-il pas pour cela attendre Kant?)." 74 But this indefinitude with regard to nature, is this not something inherent in the work of Rousseau itself? Rousseau states that nature was not a preparation for society, and yet the progression toward society is described as a natural progression. Thus it seems that in Rousseau there might be a dialectic between two different conceptions of nature as well. On the one hand, nature as a basis and temporal antecedent, and on the other, nature as a sort of force of a movement that is at least likely, if not inevitable. Could nature rightly be both, though, or is not some further distinction in order? Is Rousseau then here also starting to break away from nature as a basis for the political, with Saint-Just carrying this break a bit further?

The Concept of The Social

One of Saint-Just's greatest significances is the radical distinction he makes between the social and the political. In so doing, he establishes an orientation for the understanding of humanity that actually greatly diminishes the importance and value of the idea of the political. Saint-Just argues that the political has been confused with the social. Fundamentally, relations between persons are of the social, which is natural, while relations between peoples (e.g. nations, tribes) are of the political, or of the unnatural. 
Further, persons are alienated from their happiness, its existence being in the social state, a state which has been usurped by the political state. This usurpation takes interpersonal relations for international relations, thus creating a state of war and competition among persons within (au-dedans) via the misplacement of relations among peoples, or nations (audehors) onto the relations among persons. ${ }^{75}$

The separation of the social and the political and their separate use in political theory was not entirely new, since it was present in Rousseau and Montesquieu ${ }^{76}$, but was less express. Saint-Just makes this separation express, emphasized, and fundamental, whereas Rousseau and Montesquieu do not distinguish as clearly between these two states, nor do they as clearly distinguish these states from the civil. The greatest amount of attention to distinction in the realm of these four ideas, the natural, the civil, the social, and the political in Rousseau and Montesquieu, is the distinction made between nature and the others, while in Saint-Just the greatest distinction is between the social and the political.

The social exists primarily as a relation, and this relation is the relation of individual to individual. On this relation that is social right are founded the social relations of a human community. Thus, social relations rest on a relation, which relation is the essence of the idea of the social. The centrality of relational understanding of ideas is present in Rousseau, ${ }^{77}$ but in Saint-Just it now also forms the basis of a fully reified social which, with the natural, the civil, and the political forms the realm of human collective life and its relations concepts (See Chart I).

In the theory of Saint-Just, the social acquires its particular content through social institutions, which are established by the legislator-philosopher, either in an act of creation or in an act of realignment, or both. ${ }^{78}$ Even however, in the latter case of the establishment of the particular institutional content of the social as a realignment, this realignment is only to 
the natural, harmonious basis of the social in its generality as natural and social right, but not necessarily to any particular antecedent and actual historical social customs or practices or norms. Though the history of legislation, social institutions, and norms is consulted in reflection and with seriousness and respect, the aim is not to go back to a former time, but to assess the soundness of particular social institutions for the current time, and for the future of the society, with particular attention to their role as that which maintains the circle of the $a u$ dedans. Thus, the concept of the social is first a general relation and concordance on which particular relations are built. The particularity of the original relation is then described in general terms. For example, we can say that in Saint-Justian political philosophy the social is of affection, love, and harmony, but the particular expression of that affection, love, and harmony is the product of the legislator-philosopher of the social, who creates, sometimes through revolution, the particular society which is consistent with natural relations of harmony, which is what Saint-Just is attempting to do in his Fragments and elsewhere. The social at base then is relational, but has at the theoretical level only a general, though multiple, character (See Chart I), in terms of the attributes of this relation. Practice as the domain of the particular content of the social then also has the potential to become formative for future laws, future states, and future social theory in the sense that practice can be seen as the period of assessment of the historical value of the particular social institutions. In Saint-Just's view, Lycurgus is an important example of the legislator-philosopher of the social, since Lycurgus reflected on and created social institutions which were specifically designed to maintain the social circle of harmony. ${ }^{79}$

Even though the particular content of the social is established in the domain of the practical, the general character it is given at the theoretical level, in its being contrasted to the political, and its description as necessarily consistent with the natural relations of harmony 
and affection is an important basis for the political-philosophical activity of the legislator, theorist, and revolutionary, who somewise occur in the same person. Within the idea of the social, the first particularity is the relational nature of the social. The nature of relations themselves lies in the homogeneity of the things that unite them and the relations of the social are those between individuals who are united in common affection, as distinguished from relations between peoples (political relations) and relations between citizens (civil relations). The social relations form the social state. Aside from the social state, Saint-Just also writes of the social law or laws, principles of the social, social life, the social body, and a social pact. (See Chart I). Laws in general for Saint-Just are natural relations and not products of a contract, a contract which is itself a reification that arises from an understanding that arises from a misbegotten social. Thus, the social itself forms the very nature of law, in addition to forming its particular content. The social law is the primary law, and that with which all other laws must be consistent. The social law, which is property, antedates any contract, and forms the social body (See Chart of Relations), which is the city. Saint-Just did not complete his work on the idea of the city as the social body, nor his work on his new usage of the concept of the king as the government of this social body, but has left us with only an adumbration of what he intended. However, this adumbration is enough to find the significance of his creation of a completely new notion of the idea of 'king' in the realm of the social, though here as elsewhere, one should not be misled by Saint-Just's adoption of old or traditional concepts or discourses to express radically new ideas. The sketch of the idea of the king toward the end of the manuscript Du Droit Social understands the king as the government, and the use of this word, though puzzling at first, is Saint-Just's attempt to work within the conceptual terrain of traditional political-philosophical discourse. The king as an element of the social is correspondent to the sovereign, which resists the political, and is comprised of the people, but none of these elements of the social is 
correspondent to the prince, the locus of force in the conceptual terrain of traditional political philosophy. These three elements of the social form the city. (See Chart of Relations)

As the elements of the social stand in a particular relation to one another, so the natural, civil, social and political stand in relation to one another in their aspect as historical developments, developments that Saint-Just never describes as natural qua development. What is the force or what are the forces that bring about this movement from the natural to the political that further evidences the historical antecedence of the social order to the political order? ${ }^{80}$ What moves a human society from peace and happiness to perturbation and perversion, to disharmony and dissonance? Movement out of the social state was gradual, says Saint-Just. ${ }^{81}$ And in the Discours sur la Constitution de la France, Saint-Just gives some evidence of what brought about this change, saying that it was when the people "lost their liking of assemblies for negotiation and conquering." 82 Elsewhere, while Saint-Just seems to focus on contravention by counterrevolutionaries as it pertains to revolutionary action, it must be remembered that this action is in the service of the ideal of the legislator-philosopher, in the service of the restored ideal of proper social relations:

Though he professes a theory of decline, Saint-Just is convinced of man's natural goodness. What is actualized in the change from the social to the savage state is not a defect in human nature, there was no fall owing to some innate corrupting passion of human nature, but merely an accident, for which the sole factor responsible was theologico-political subterfuge. ${ }^{83}$

The particular temporal aspect of the social in Saint-Just which is its historical errancy however, remains somewhat uncertain in its origin, though it is described as a mistake, and as accidental. If the contraventions of subterfuge which acted against the natural social 
relations both originally and during the attempt to reestablish these relations via revolution were not natural, what were they originally? The question goes back to, and may be an artifact of Rousseau's equivocal conception of historical progression and nature. What is the origin of the unnatural, of the corruption of social harmony, of the displacement of the political onto the social? We can well say that this latter displacement was a mistake, and this is consistent with Saint-Just's view, but how do such mistakes in relation to the social come about? Do they come about perhaps when the legislator-philosopher fails in his or her duties?

The social relations within a society are founded in nature but are created by the legislator, who can be seen as the replacement for, or as the new guise of, the political philosopher. In addition to recognition of the need for realignment to nature, for social institutions, and for revolution, the legislator must also establish institutions. Institutions must be formed on the basis of the legislator's correct assessment. There must be a correspondence between the laws and the existing social relation, and this requires the discernment of the legislator, however this assessment is not an assessment that seeks to simply reestablish the substantive content of institutions and of the social; it is work that looks to the future and that is creative, even as it draws on both the content of past social relations in various societies, and on a history of the validation of the necessity of institutions which support these relations:

Le législateur commande à l'avenir; c'est à lui de rendre les hommes ce qu'il veut qu'ils soient; selon que les lois animent le corps social inerte par luimême, il en résulte les vertus ou les crimes, les bonnes mours ou la férocité. La vertu de Lacédémone était dans le caur de Lycurgue, et l'inconstance des Crétois dans le cour de Minos. ${ }^{84}$

The legislator then does the work of recognition, alignment, and creation, and, insofar as 
the Saint-Justian idea of the legislator contains and replaces the traditional idea of the political philosopher, persons who do not fit the historical notion of philosopher and whose proper focus is the social and not the political, emerge more prominently and perhaps even more legitimately as "political philosophers". Leaving aside the question of the historical reality of many of the persons Saint-Just looks to as examples of institutional legislators, ${ }^{85}$ the new political philosopher who would be brought about or historically reified by the French Revolution as social revolution is a person who necessarily fuses theory with practice in the straightforward sense of combining some form of reflection and contemplation with historical awareness and legislation. Lycurgus is exemplary here and prototypical. In the light of the Lycurgan referent and others, Saint-Just's own life emerges as the actualization of the ideal of the theorist as practitioner and political actor, and his own protomythic and legendary status blurs the line between personage and person even as it moves us in the direction of at least the attempt at the instantiation of this type, of a type vécu. ${ }^{86}$

As with the concepts of nature and of the civil in Saint-Just's theory, the concept of the social is elucidated by the discovery and understanding of the idea of independence. This discovery and understanding includes the discovery of morality that emerges from the social. In Saint-Justian political philosophy, there are levels of independence, and these correspond to the social and to the political, to the interior and the exterior, or, as Saint-Just here puts it, there is an "indépendance sociale" and an "indépendance extérieure." The former is a moral independence, and is based on relations which unite, and the latter is an immoral independence, based on physical relations. ${ }^{87}$

The former independence, the personal independence on which the social state then rests is, in accordance with the utilitarian morality that is its cause, also a mechanism by 
which each one lives both for himself or herself and also for all in this social state ${ }^{88}$ For Saint-Just, this mechanism of independence provides for the security of all within without the presence of force ${ }^{89}$ Although the exercise of political force in the external world in itself "....ne doit point ôter à ses membres leur indépendance sociale ${ }^{90}$ there can be degrees of independence in the social realm: "...le principe de la vie sociale est dans l'indépendance et sa durée dans la mesure de cette indépendance. "${ }^{" 9 l}$

The latter independence is brought about by a morality that is ultimately utilitarian: L'indépendance des peuples n'a qu'une cause morale, l'inutilité de conquérir."192 This utilitarian calculus of need in turn rests on Saint-Just's discussion of population size in relation to land, and hearkens back to Montesquieu. The exterior independence of people from one another, which is something like a natural law of species independence, here has the function of setting up the social state and thus the possibility of morality. After the setting up of the circle within which natural social, moral relations can exist, the maintenance of this morality also is dependent on the social realm's continued separation from the political, and one specific way in which this occurs is when social institutions guarantee all the basic necessities of life and harmony, and when space is plentiful. Though even the exterior, or political independence of a people has a function, it is the individual's independence in the interior world of the circle which has the subsequent utilitarian function of maintaining social harmony. As long as this internal harmony and individual independence is maintained and guaranteed by social institutions, there is no value in turning one's interests to the political, to attacking other peoples. Independence is related to the social law of property in that one's only property is oneself and portion of the land shared by all: "Il est deux sortes de propriétés: celle de soi-même et celle de l'empire ou du territoire, ${ }^{, 93}$ with the concomitance in law and institution that these are inviolable, even if they are heavily regulated by the civil, since it is 
in the civil realm where the regulation of property occurs. The civil realm though is only posterior to the social and must be derived from it, and thus no regulation of the civil realm, even if it can dictate specifics about the limits of use, can violate the social law. Saint-Just gives at least two examples of the preeminence and inviolability of the social law. One is that marriages, which are of the civil realm because they have to do in his view with the need for reproduction and its regulation, cannot be made eternal, since this would alienate a person from herself or himself, and this would violate the social law that one's own self is inviolable and inalienable property. A second example Saint-Just gives of the inviolability of the social in its aspect as the social law of property is that a people may elect a chief, but this people "ne peut se donner à lui." ${ }^{194}$ Giving oneself to anyone in a manner that is akin to giving away one's proprietary rights to oneself or to one's societal territory, is a violation of the social law.

Ultimately, the distinction between the social and political and the development of this separation historically perhaps makes most sense in terms of a discussion of power, and of the psychology of power as the center and fundament of both the operation of the political (politics) and as a focus of political theory. The idea of power incorporates the realm of questions having to do with force and authority. While Rousseau shows that authority is actually power without the need for force, ${ }^{95}$ Saint-Just attempts to create a theory and practice of human community in which the problematic aspects of power are removed, and he does so by focusing on force. Thus, though both theorists problematize power, Rousseau's shifting of the questions of power to those of authority and to the repositories of power and to its authenticity does not remove its foundation, which is the psychology of power, and, at least in the letter of Saint-Just's theory itself, force as the problematic element of power is merely banished and ostracized in the purification of the au-dedans. In the theories of both 
then, the psychology of power remains intact as a fundamental question which forms the political. In Saint-Just's merging of theory and practice however, one can find the possibility of the transcendence of the psychology of power and the constitution of the political by questions of authority, which concept social philosophy subsequent to Saint-Just has continued to make central even as it seems inimical to its spirit and democratic and liberatory goals.

Here it is argued that, emerging from Saint-Just's experience in the integration of political philosophy, political practice, and revolutionary practice, are possibilities for the understanding of human community which transcend the political, and are themselves revolutionary. The integration of and relationships between the elements of Saint-Just's experience rest profoundly on his idea of the social. It might be said that, in making the social primary, and also in performing political actions consistent with his ideals, Saint-Just had been touched by the zeitgeist of the late eighteenth century, when Rousseau wrote of a social contract, and not a political one, and when Hegel's work looked away from philosophy and toward social theory. ${ }^{96}$ Even if a particular type of new understanding of philosophy and of the political, and a concomitant trend toward the social is discernible in Saint-Just's time, ideas of the social followed many different paths in the ensuing centuries. Later descriptions of the social, as found in social theory as it developed as a discipline and elsewhere, are not the same as the idea of the social in Saint-Just's social theory, which died an early death along with the Revolution.

Though the concept of the social remains in formation even in our time, and has a definitional character that is more amorphous ${ }^{97}$ than that of the political, Saint-Just, moreso than many thinkers of the social after him, helps fill in the conception of the social, and does so in more than one way. The preeminence of the social in Saint-Just can be seen as the 
prefiguring of the end of power dynamics as the content of the political, and the transcendence of the political as a mode of understanding, creating, and living in human communities. Saint-Just's understanding of the social is so valuable because even perhaps the subtlest form of power, the very idea of authority, is inegalitarian in its 'political' import. The social as the source of right and as one stage in the transcendence of right itself is really the possibility of the end of the group of questions connected to power which have comprised our understanding of the political, including, but not limited to questions about force, authority, and power itself. In the experience of Saint-Just, these questions as elements of the traditional political are both part of the obstacles to implementation of theory and to the sustenance of practice (the operation of society) informed by theory:

Je ne suis d'aucune faction; je les combattrai toutes. Elles ne s'éteindront jamais que par les institutions qui produirent les garanties, qui poseront la borne de l'autorité et feront plonger sans retour l'orgeuil humain sous le joug de la liberté publique,

and also obstacles to the proper exercise of the role of the political theorist, that of one who recognizes the misalignment of the social.

Incorrect supposition about the 'nature' or 'condition' of human beings can be seen as the root of the development of a theoretical world whose conceptual framework is misbegotten. This is Saint-Just's assertion as applied to political theory. The savage state of man has not been understood and properly recognized by the political theorist as being a later development in human history, and a harmonious state of natural social relations as being an earlier state because the roots of the development of the psychology of power as a theoretical tradition lie in the false attribution of the origins of the need for authority to what Saint-Just sees as natural (social) man:

L'homme fortuné mena la vie socialle dans les bois, ceci doit paraître étrange, mais c'est ce prejugé qui est étrange qui appelle vie social celle d'hommes qui 
se redoutent, s'envient, ou se haissent. ${ }^{99}$

Mutual fear, mutual envy, mutual hatred; these are the false attributions to natural man that carry with themselves, as false inferences, an emergent political understanding of human community that is itself also false because it is misbegotten.

The social function of theory and action as correlatives of actualization then, is corrective, but it is also creative. It is somewhat understandable that the theoretical understandings of human community would carry with them the false inferences of force, power, and authority, since, on the non-theoretical actual level of the history of human community, that history which has been largely observed by theorists, there has been corruption of natural social relations in the form of usurpation of these natural social relations by force, and this corruption has been the object of political theory. Various theorists of the political are corrected by Saint-Just for their mistaking the actual for the social. Montesquieu, for example, takes what he describes as necessary natural consequences as natural social relations, which consequences are both different from natural laws and capable, as they indeed were, of being falsely inferred. Both Hobbes and Rousseau describe a part of the human condition well and accurately according to Saint-Just, but err in their failure to see that what they are describing is a historical sociopathology, and not naturally social relations. Inherent in Saint-Just's idea of errors occurring historically in the theory and practice of social relations is the idea that the continuation and perpetuation of natural relations is not necessary, as are relations in the laws of physics. This recognition itself seems to preserve a place for theory in a new conception of revolution, since it is in the realm of theory that the recognition of the need for historical correction of the corrupted social relations (social relations in their actuality) occurs. 
In revolution then, theory is already in Saint-Just the recognition, or consciousness of historical developments, though Saint-Just does not take the later Marxian step of using a scientific template for this understanding, which scientization for Marx makes both relations between persons and corrections thereto themselves necessary in some sense. For Saint-Just then there is fallibility, pathology, corrigibility, both in the actual history of social relations and also in the interpretation thereof. The idea of alignment or of misalignment is transitive to that to which a society is aligned and carries with it the understanding of the theorist as one with the power to recognize misalignment. That to which there can possibly be such a misalignment can, fundamentally, be recognized as droit social.

Saint-Just raises the possibility of historical necessity, or the history of class struggle, being an accidental history in the sense that power struggles, and therefore class struggles, are not essential (necessary), but rather mistaken trajectories of contradiction which result from failure to remain in accord with social right. Feudalism then, for example, as a particular distribution or arrangement of power is pathological but not necessary. The moral base of the social, the original, natural state of human beings, is variable and not constant, since social relations are species-specific for Saint-Just. Social right then remains locally dependent, yet neither constant in the manner of natural right, nor universal in its content's applicability. As such, it is an intermediary between the idea of right and a conception of the social which has dispensed with the notion of right. The role of political philosopher then, could be said to become one that involves a dual task of alignment, with the two levels of this role of alignment each having a moral component. The first role is that of the alignment of the theoretical with the actual, both in foundation and in established practice, which alignment comprises the moral criterion of integrity; the second role is that of one who is conscious of contradictions, or, to put this idea in the terms of the discourse of right, of one 
who is conscious of social right.

The idea of a correct interpreter of history though, can be identified both with bourgeois thought and with Hegel, but this view of a social theorist is not exclusive, and in fact finds both its origin and its mandatory universality in the class circumstances of the proletariat, even if the theoretical base of Saint-Just is still the discourse of right: "C'est au peuple d'exercer la démocratie et c'est à vous de gouverner la république," ${ }^{100}$ Saint-Just writes to the functionaries of social right. ${ }^{101}$ An understanding of Saint-Just's conception of the social by and through which this 'exercise of democracy' occurs as the combination of theory and practice, points to a future in which every person in a society is, at least potentially, a theoretician of the social.

The Concept of The Civil

Central concepts in the thought of Saint-Just, such as the civil, the social, and the political, are defined and understood as relations. Thus, the civil state in its most exact sense is the relations between the needs of citizens (See Chart I). ${ }^{102}$ These needs are needs to possess things, but not to own them in the fullest sense, since all possessions are not property, which consists only of oneself and the totality of land of the social state held in common. The distinction between possession and property is central in Saint-Just, and the civil is understood purely in terms of possession:

La loi sociale n'est autre chose que la propriété, la loi civile est la possession; 
l'une dérive naturellement de l'autre, si dans la loi sociale, l'homme est propriétaire de son champ, la loi civile doit régler l'usage de sa propriété et de sa possession sans les altérer.... ${ }^{103}$

The practical manifestation of this need to possess is commerce understood broadly, and this commerce is what constitutes the civil state. ${ }^{104}$ The civil state in practice is comprised of the commerce of needs, and legitimate commerce is the commerce of legitimate needs, which do not include, for example, speculation. ${ }^{105}$

Again, only two types of property exist for Saint-Just, oneself and l'empire, or the territory of the state, which belongs to all. Only property is inalienable; possessions can be gained and lost, and this coming and going of possessions is the commerce of civil life, a civil life which is entirely within the circle of the au-dedans. Possessions within the civil state are not property, since property can never be exchanged; trafficking in property is against the social law. In the ideal civil realm, insofar as it can be separated from its origin, the social, there is no property, but, in the civil state, "l'homme dispose....de la possession de soi-même et de celle de son champ qui est une fraction de la propriété souveraine. ${ }^{106}$ The consequences of this limit the possibilities of commerce such that one can never sell oneself, and one can never give up one's right to oneself in marriage.

It seems clear then that, despite the fact that the French Revolution was a bourgeois revolution and supported the right to private property, that Saint-Just had a society in mind where possessions did not have their origins in greed, and the notion of commonality ruled the commerce of needs. Ultimately, this society was to be primarily one of moderate parcels of land which were tilled by those who resided on them; thus, one always has, but there are differences in possession between individuals. However, these individual differences are greatly mitigated by the restrictions in the institutions which Saint-Just lays forth, which 
institutions will establish a social which the civil realm creates, derives from and supports and maintains:

Mais la loi civile ne peut-elle même lui tracer d'autre loi que celle de son indépendance et faire en sorte que tout le monde étant indépendant, personne ne soit le plus fort et ne puisse entreprendre sur les droits de la cité $?^{107}$

The civil realm as a part of human society in Saint-Justian political philosophy is the least developed $^{108}$ of the concepts which form the framework for a historical and transpolitical understanding, especially with regard to the principle of civil society, equality. Nevertheless, Saint-Just does describe the civil principle, equality, negatively, as being not the modifications of power of the former and corrupt civil realm, and as being not in the quality of things, but rather in security, ${ }^{109}$ which security is guaranteed by the laws and government of the civil realm when it is in accordance with the social. Equality then, in theory, is not equality of property in the traditional sense, even if the institutions which revolutionary exigency makes more and more strident eventually result in institutions and policies which push strongly in this direction. Saint-Just seems to want to maintain something of an individuated identity that is social and yet not susceptible to its cooptation by elements of force, which subject some to others under the guise of equality. Thus, independence is the principle of the social, and the principle of the civil, equality, comes from it, but is not prior to it:

Mes idées se suivent, plus le pacte social est éloignée de l'independance, plus l état civil s'éloigne de l'égalité jusqu'à ce que, par l'ordre les choses extrêmes, l'égalité civil se retrouve là où la dépendance est absolue. ${ }^{110}$

For Saint-Just, the social body is susceptible to becoming a contractual body, that is, a body within which contractual relations have become relations between persons, and this latter 
state is what he calls the social pact. The principle of the social state is independence, while that of the civil state is equality (See Chart of Relations). When a regime of proper and uncorrupted social relations exists, a proper civil state is both a possibility and a necessity because of the interrelationship of the social law and the civil law, which have as their underlying principles independence and equality respectively.

The real and former civil state (Civil 1), derived from nature and close to synonymousness with the social, is founded on natural equality, and Saint-Just names possession as the law of the civil realm. The civil law as possession however, more specifically and more comprehensibly, is twofold, being at the level of theory and more abstractly, the basis of civil life and citizenship themselves, the commerce of needs themselves, but also being the regulator of the natural, or moral commerce of possessions. Consistent with the relational nature of Saint-Just's concepts of the social, the civil, and the political, the former aspect of the civil law is even more specifically, the commerce of legitimate needs, or the relations of needs, the latter the regulation of these needs or relations. Equality is the principle of the civil law of possession, and the civil law in its second and regulatory sense above overlaps the domain of the social, regulating both the commerce of the social and of the civil, that of property and of possessions: "l'homme est propriétaire de soi-même et possesseur de son champ, la loi civile doit régler l'usage de sa propriété et de sa possession sans les altérer."111

In our normative, contemporary understanding of the concept of 'the civil', 'the civil' is really just a division of the political. It is that part of politics which is concerned with the internal affairs and relations of a state. Saint Just though, writes that the political is purely exterior, and thus any subdivision of it which would encompass or have to do with the internal relations or affairs of a state, or the relations between its citizens, would not be 
properly political. These relations in fact are now political, but this is a corruption that arises from ignorance, and this understanding of the civil as something that is a division of the political is then correct insofar as it describes the actuality of human existence now, but misbegotten insofar as the political is misunderstood and overextended in this actuality. The political, the relations between peoples being overextended into the social domain, the domain of relations between individuals, the civil state as we now understand it is corrupt as well, though not inherently or necessarily so. For Saint Just, it is a matter of getting back to a proper understanding of human life, and such an understanding would place civil relations in the realm of the social, and thoroughly apart from the realm of the political.

To understand Saint-Just's idea of the civil then, it is necessary to understand that Saint-Just refers to two different civil states, the civil state as it actually exists in his time (Civil 2), which is the state corrupted by the misplacement of the political, and the ideal civil state (Civil 1), where relations are in their proper order and position:

....Pour que la règle civile soit légitime, il ne faut point qu'elle émane de la loi politique, car alors le système de la domination fait le droit. Alors les relations civiles ne sont plus des contrats par essence ou par leur propre fait, mais des obligations résultantes d'une volonté étrangère. ${ }^{112}$

Both the social and the civil then are defined primarily in contradistinction to the political, and it is the negation of the political and the alienation of the relations of power from the society of the au-dedans which form the conceptual ground for the properly constituted civil (See Schematic 3).

The civil state exists in an especial duality then, since the civil state is really derived from the social, or from social relations, and the civil state exists as the internal administration of life built on and consistent with these relations. As such, the civil realm in its ideal actuality largely consists of the modulation of the social relations, and of daily life 
and interaction consistent with these relations. The social relations in a society can be created or returned to, since they are referential only to the natural, but the civil realm and its relations are dependent upon inalienation of the people from their natural social relations, and thus any alteration of these natural social relations will produce a corrupted commerce of false needs. Once the civil realm exists as such a corruption, the realignment of the actual social with the natural social must occur before a new civil realm can be constructed or before such a realm can be operative. Thus, the apparatuses and interactions of daily life, the civil realm, can occur as potentiality, that is, as the proper alignment of the civil with the social, which alignment is potential and not actual, or, the civil state can occur as corrupted actuality, as falsely derived from a corrupted or wayward comprehension of social relations. An interim period of realignment, or revolution, could then potentially have to reckon with the problem of the commerce of a corrupted civil realm continuing to corrupt a reconstituted social realm, and the reconstitution of both the social and the civil adds both value and urgency to action, and this urgency itself urges the corrective form of revolution.

As there is a historical confusion of the relations of the political with those of the social, there is also a resultant historical confusion of the relations of the social and those of the civil:

....la règle civile dans tous les engagements doit être calquée sur la règle sociale. L'une et l'autre étant confondues, le noud social en est plus resserrée et la société qui subsiste d'elle-même, comme je l'ai dit par un principe naturel, est liée dans tout ses parties par la règle civile. ${ }^{13}$

Saint-Just means here that relations between persons, in the corrupted actuality of the society, have become relations between needs. Since the civil state is founded on equality, legitimate relations between needs can never break the social bond produced by the sharing of the totality of the land (l'empire) as a unity and by mutual affection, nor can persons traffic with property, falsely placing it in the realm of the civil, the realm of legitimate commerce. Some 
examples of what this means in practice are the denial of familial piety (See Schematic 2), and the selling of oneself or another into slavery, either slavery in its more obvious forms or slavery in its less obvious forms:

Nous ne ......conaissons [la nature] que dans le petit nombre de rapports que la loi politique n'a pas infecté, mais elle a fait toutes choses sous le joug. Les lois civiles qu'elle a faites sont des codes de sauvages, les lois du père sont l'arme du tyran contre le fils, du fils contre le père, de l'époux contre l'épouse........En effet ce qui fait que par la loi politique, tout le peuple est assujetti, fait aussi que dans l'état civil, une partie du peuple est esclave de l'autre. $^{114}$

The relationality of the social and the civil in the theory of Saint-Just has an historical and ordinal element which, when understood, divides the civil into its two forms: the corrupt form and the correct, or ideal form. This ordinal element is evidenced by the fact that the division of the social and the civil is not a strict bifurcation so much as a movement along a continuum from the political to the civil to the social to the natural, a movement that is retrogressive in its historical aspect, but progressive with regard to ideals of equality and justice. The idea of movement backward in time is inherent in the Hegelian dialectic, where the negation of a conceptual framework by a progression that assumes aspects that seem regressive because the conceptual framework being negated must assume intermediate forms which emphasize its various aspects, and some of these aspects appear to fortify socially regressive ideals, even as the larger process of negation moves toward absolute freedom. ${ }^{115}$ An understanding of the temporal movement of elements of Saint-Just's theory is what helps to illuminate the duality of the civil realm in Saint-Just, and the question can be asked of whether or not the position of a historical trajectory within political philosophies is the antecedent to a focus on theory and action as temporally distinguishable. In this regard it is worth quoting at length Thomas Nail's description of the temporal aspects of revolutionary 
actualization as they exist in the political philosophies of Gilles Deleuze, Félix Guattari, and Subcommander Marcos:

Revolutionary political transformation thus occurs as the prefigurative emergence of a particular new present (from within the old) that both "rewrites and reinterprets the totality of potentials that already existed in stratified form," as well as creates "an action of the future on the present," and "the present on the past" This is what Deleuze and Guattari call "reverse causalities." More than a break or zig zag in history, they argue, what is to come already acts upon "what is" before the future can appear, insofar as it acts as a limit or threshold continually being warded off by the past's attempt to preserve itself. But once a new present emerges it is seen to have been on its way the entire time. If, from the perspective of the plane of organization, revolutionary novelty may seem to emerge "out of nowhere," this is only because it was unable to see or represent the prefigurative labor of deterritorialization before it had transformed the political conditions under which it could be seen and understood as such. However, from the perspective of the revolutionary struggle, the emerging event appears entirely consistent and intelligible as that which will have been. ${ }^{116}$

With this in mind, if we can ask if theories which have a historical element, such as those which derive right from a historical anthropology such as that found in state of nature theories can bring about actions, we can also ask if such actions can bring about theory. Consciousness of the temporal machinations of the dialectics of theory and action then, one might presume, can elucidate elements of theory within itself, insofar as the dialectics of theory and action allow an "in itself' for either theory or action.

Even without the focus on movement in time within the theory of Saint-Just itself, Saint-Just's theory of the civil is still Hegelian, argues Abensour, who does not point up the temporal divisibility of the civil: "[La société] secrète spontanément un droit social commun, aboutissement des rapports des besoins et des affections des hommes, de la "société civile» au sens Hégelien." 117 The idea of negation within the theory of Saint-Just itself, on which plane of examination Abensour remains, then reproduces, anteriorly, other elements of a 
Hegelian consciousness, such as the overlap of the civil and the social in the sense that the civil realm is the realm of the regulation of the social, but also intimately connected to it and both an outgrowth of this realm and a creator of it. Abensour is then focused on the theoretical component of Saint-Just which is, in relation to revolution, radical, and sees the relationship of the social to the civil in Saint-Just on this plane, in relation to which a Hegelian-Marxian dialectic is exterior, with its Marxian component found in the separation off of the civil realm in the sense that this is the realm of economic production and the commerce of needs:

La pensée de Saint-Just, bien qu'elle propose l'homme propriétaire de soi-même, n'appartient pas au courant de l'individualisme possesif, puisque cet homme est conçu comme partie d'un tout plus vaste dont il doit renforcer l'unité organique par sa projection, soit économique, soit affective. On mesure, par ses traits, combien Saint-Just se situe loin de l'idéologie bourgeoise. N'a t'il pas échoué à faire la synthèse juridique entre propriétè et possession? ${ }^{118}$

The Concept of The Political

The political emerged when "the prince separated from the sovereign,"119 which in Saint Just's political philosophy followed the loss of the people's taste for assemblies for negotiation, cultivation of the land, and for conquest. This separation was a process which took place over time and which was imperceptible: "[Cela] arriva a la longue et par une alteration insensible. ${ }^{\prime 20}$ Far from being a permanent change, the emergence of the political, 
which is in essence a confusion of relations, can and must be reversed. This reversal in fact, is the main goal of the Revolution in Saint-Justian political philosophy, and the Revolution is the testament to the validity of an ideal and a testament to the original goodness of human beings, and Saint-Just truly believes that a return to a prepolitical state is both possible and desirable.

For Saint-Just, the political has properly to do with the external affairs of a state or society, and not with the internal, social life therein, and it is, specifically, the relations between peoples - the relations between tribes or nations (See Chart of Relations). As the relations between peoples rather than the relations between individuals, the political has its corollary in interspecies relations. The political is unnatural as an element of society, and is a product of convention (see Schematic 2). The political has become improperly extended to the realm of the social, thus insinuating force into social relations, where formerly unity in natural harmony reigned. The internal manifestation of the political, which in turn corrupts the civil, is force, which creates disunity and disharmony in the au-dedans. ${ }^{121}$

The entrance of force into the au-dedans is enabled by a lack of vigilance with regard to governance, a loss of taste for assembly and its attendant manner of making decisions. This historical change is unnatural since for Saint-Just the sovereign is always naturally coincident with the people and with the prince. The change and its prevention also give rise to the importance of the legislator, and his or her valuation over the magistrate, since a magistrate is, in its very idea, political, while the legislator, though limited in power and below the level of the people, is the only truly acceptable and legitimate element of a government, and is a representative of the social relations and the society:

Les anciens Francs, les anciens Germains, n'avaient presque point de magistrats; le peuple était prince et souverain: mais quand les peuples perdirent le goût des assemblées pour négocier et conquérir, le prince se 
sépara du souverain et le devint lui-même par usurpation. ${ }^{122}$

The body of the people's representatives, or the simple assembly of the people for the purpose of making decisions about external conflicts had acted as a buffer against the outside world of force, of politics. Once this altération ${ }^{123}$ or "loss of taste for assemblies" occurred, the au-dehors began to invade the au-dedans. This was the birth of the political, says SaintJust, and, after the invasion and usurpation, "on ne discerna plus alors l'état des citoyens. " 24 Saint-Just's conception of the political is radical in its almost total denigration and exteriorization of the political in relation to human society. In this conception, central elements of the political as it was construed up to the time of Saint-Just are rejected. Contract theory is totally repudiated as a province of the political; it is an effect of the conflation of sets of relations. The idea of self-preservation, a basic element of the heritage of state of nature theories, is misplaced, and this misplacement has created fundamental misunderstandings of the nature of human society: “On a mal appliqué le principe de la conservation, il n'appartenait qu'au droit des gens, c'est-à-dire, qu'il était de peuple à peuple."125

Saint-Just's historical description of the political takes the explanation of its origin one step beyond the "loss of taste for assemblies" to assert that the limitations of territory created the inharmonious relations that are the political. The civil realm's commerce of legitimate needs is only possible when there is the possibility of these legitimate needs being satisfied. In the absence of sufficient land for the society of the peuplade due to an increase in the ratio of persons to territory, conflicts between the persons in the social circle arise:

On a découvert dans l'Amérique les îles peuplées : là, il semble que l'émigration étant impossible, la force devait refluer sur elle-même, mais ou la terre suffisait à leur besoins, ou ils formaient divers peuples qui s'exterminaient. ${ }^{126}$ 
With such a formulation, Saint-Just is able to keep the social and political realms quite completely distinct, and the idea of the good has an unequivocal location, albeit a location within a temporal-historical lineage.

In Saint-Just's political philosophy, there is an descent towards the political as one moves away from this world of the au-dedans, and this descent is more specifically toward the relations and laws of force, which Saint-Just also connects to power generally, impugning the latter with regard to the interior life of social relations, and thus calling into question not only the position and value of the political, but the position and value of political power:

En effet, le citoyen n'a d'abord de rapports qu'avec sa conscience et sa morale; s'il les oublie, il a ce rapport avec la loi; s'il méprise la loi, il n'est plus citoyen: là commence son rapport avec le pouvoir. ${ }^{127}$

Saint-Just wants to shelter the people from the political, from power, and the work in this realm of the political devolves to the servants of the people, the state functionaries and representatives. They are beholden to the sovereign, to the people, and, by virtue of the fact that they must traffic in the political, in the realm of power and of force, they are not labeled citizens, since force must not be at all a part of this social world. Saint-Just writes,

Quiconque est magistrat n'est plus du peuple. Il ne peut entrer dans le peuple aucun pouvoir individuel. Si les autorités faisaient partie du peuple, elles seraient plus puissantes que lui. Les autorités ne peuvent affecter aucun rang dans le peuple. Elles n'ont de rang que par rapport aux coupables et aux lois. Un citoyen vertueux doit être plus considéré qu'un magistrat....Lorsqu'on parle à un fonctionnaire, on ne doit pas dire citoyen; ce titre est au-dessus de lui. ${ }^{128}$

The relegation of the political to exteriority in relation to the life of the citizen is a step on the path back to nature, since for Saint-Just "le droit de l'homme est la nature ou 
l'indépendance, de citoyen à citoyen la possession, de peuple à peuple il est la force...." The ascending path to nature then includes the civil as the vestigial template of the evanescing political with its inherent force, and it also includes the more ideal social state, which aims at and is closer to nature, the most ideal state of existence. These steps on the path to nature have then also an important temporal aspect, and the whole theory of SaintJust is in dynamic motion toward this goal, with dialectical interaction and synthesis going on within an overall movement toward nature, a movement which in Saint-Just's time necessitated revolution.

To take the denigration of the political up and away from the work of Saint-Just and analyze it in the larger context of political theory, and beyond state of nature and contract theory, one might ask how this separation in Saint-Just is different from that of others. To wit, there is Aristotle's view, mentioned herein above, that actual political work or action, the life of the politician, is inimical to political philosophy because the busyness it involves renders contemplation impossible. Then there is Nietzsche's "necessary dirt of all politics," ${ }^{130}$ by which he means that politics, here again, the active life of politics, cannot be rendered clean for the political philosopher due to the hierarchical nature of societies and the necessity of mixing with the "rabble" when one engages in the political realm. And liberal feminists have separated the political from the ethical. ${ }^{131}$ Saint-Just retains equality as a principle in his ideal society, and thus Nietzsche's hierarchical view of political activity, even though not tied to nature as a standard, is not comparable to Saint-Just's ideal in that it is inegalitarian. By the same contrast, liberal feminists have pointed to women's exclusion from the realm of the political, which has tended to diminish its legitimacy in the contemporary period. ${ }^{132}$ 
To the extent though, that we can trace a lineage of the political to Greek philosophy, we can place Saint-Just within the distinctions which Plato and Aristotle make between theory and practice. Since for Saint-Just the idea of the good, though having a natural lineage, is produced by social intercourse, the idea of doing philosophy for its own sake, the

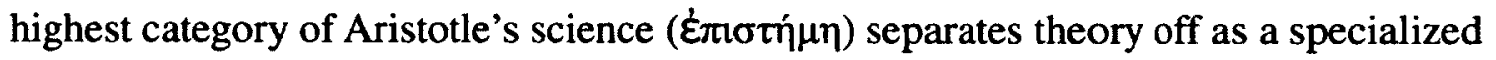
interest of certain persons who analyze society in the mode of spectation. This element of

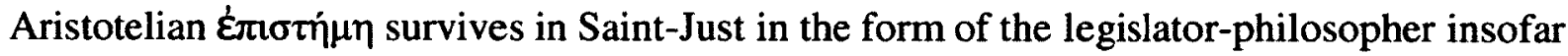
as he or she can be named as such, even if he or she is directly responsive to the people's interest. The idea of the discernment of the good in Saint-Just is present in the idea of the legislator-philosopher's work of discernment of proper social relations, which occurs alongside his or her responsiveness to the express ideas of the people. However, in most senses, the good within the polis for Aristotle is not universal, but rather different goods are attainable by different characters. Thus, the idea of the polis in Aristotle is more fragmented than the idea of the social realm in Saint-Just, and the Saint-Justian political becomes the locus of such fragmentation. The "polis" is necessarily democratic for Saint-Just. Since Saint-Just's idea of the natural is limited in its specific content and is effectively a device for the theoretical justification of the social, the particular content of the social comes more from the experience of the history of a people than from nature. In the active life of the society then, the idea of right conduct has the imprimatur of nature only in the very general sense of society's being based on mutual affections. The telos then, of the Saint-Justian society is more variable than that of the polis, and, less tied to nature than that of Aristotle's polis, though, in abstraction from its historical components, the good of Saint-Just's social realm occurs as a universalization of Aristotle's $\varphi \rho o ́ v \eta \sigma \varsigma^{133}$.

Insofar as we can describe the political in Saint-Just in its purely theoretical aspect and 
dehistoricize the concept, we can situate it more squarely within Plato's second type of theoretical science, described by Franco Volpi as that which "produce[s] new realities that did not previously exist." ${ }^{\text {,134 }}$ Although the experience of Saint-Just portends a post-political understanding that surpasses the conceptual frameworks of power, force, and authority, in the discourse of right in which Saint-Just largely remains, the political does have a function in relation to human society that is for Saint-Just natural and that helps to form the possibility of the society of social relations. Political right, though relegated to exteriority, is the relation of peoples to peoples, and serves to delimit the society, the au-dedans, and guarantee an insulated if not insular realm in which natural social relations can remain such: "[Ce droit politique] érige un peuple en souverain....on voit par là que le peuple comme être collectif dépend de la loi politique qui constitue sa souveraineté." ${ }^{135}$ In this purely theoretical sense then, the political retains the possibility of a Platonic classification as "that which produces new realities which did not previously exist," since Saint-Just describes the work of the legislator-philosopher in separating off most functions of the political from the social as creation.

Within the continuity of theory and action and their potentiality as unity that SaintJust's experience brings to our attention, this work though is historically connected, that is, it has a temporal progression or regression that has a narrative, and this history cannot be disconnected from the essence of the political or from the actual circumstances which form the realization of the political's interiorization. The specific forms of the relations of the audehors are relevant as antecedents to the idea of the extraneity of the political in Saint-Just, and thus, with regard to the question of the counterrevolution and its identification with the world of the au-dehors, once can notice again a correspondence of theory with the actual again and even a question about the directionality of the relationship. Did the usurpations 
and destructions of the counterrevolution beget the ideas of the social and the exterior political, or at least inform them, or, was it the case that Saint-Just's theory was prescient enough to see this invasion of the social world of the French, this corruption of its social relations because of his examination of the history of social laws, or are both true, such that the multidirectional interaction of the theoretical with the actual could be said to have found the origins of its dynamic tension in some sense in the political? If the second of these is adequate as an explanation, then a dialectical interplay of action and theory can perhaps be modeled for these relationships. If one adds in the revolutionary (exigent) circumstances, which change the position of practice, the position of a more complex dialectic becomes possible. (Diagram 2)

\section{Diagram 2}

\section{Revolutionary Experience as Tripartite}

Theoretical

$\underline{\text { Actual }}$

Actualized

Practical

Social State

Political-Social State

Social State

Theory of the State in Practice
The State In Practice

Remains Immanent
The Social

State

Returned via

Revolution

Here practice is not the total negation of theory, but also theory itself as it exists as its 
own actualization. Theory exists in a simultaneity of theory in itself and in its negation. This places revolutionary circumstance then as the usurpation of the theoretical actual in its actuality, and this forms a third, or further negation. The Revolution is both the corrective for the destruction of or impediment to the theoretical's actualization, and also a force itself, as the yet unseen historical future template for revolution. Its own actualization, which occurs in the service of the actualization of theoretical practice, awaits a future phase of the dialectic, in which phase various elements of revolutionary exigency become the content of practice.

In this understanding, Saint-Just's life and work are seen not merely as swept up haphazardly by "la force des choses" but as a comprehensible link in a historical chain of the realization and recovery of the social out of the political, as well as a basis for future development bases on a corrective of historical circumstance, itself based on a historical consciousness whose actions form a link in a chain of consciousness and its manifestations. But Saint-Just does not make the connection to an expanding historical consciousness that Kant and Hegel will make, in part because he is burdened by the concept of nature. But what does nature mean here? This question is perhaps almost the same as the question of what the social state is, or as that of what the relations between persons are. Saint-Just's work was less concerned, at least up until the time of his death, with an elaboration of these social relations as it was with securing their peaceful existence and perpetuation, believing that their perturbation would be perennial without their necessary guarantors, the social institutions that serve as the bulwarks against the political.

The portent of a post-political does not only emerge from an ex post facto observation of Saint-Just's sociopolitical experience, but is also already present in the difficulties that 
Saint-Just faced in implementation, such that by the time of the Speech of 9 Thermidor, his own expression carries this portent in that it has moved toward further disparagement of the political, which is seen as having produced the disunity, the factions which Saint-Just sees as having destroyed the Revolution and which were to presently bring about his own death:

Si vous voulez que les factions s'éteignent, et que personne n'entreprenne de s'élever sur les débris de la liberté publique par les lieux communs de Machiavel, rendez la politique impuissante en réduisant tout à la règle froide de la justice. ${ }^{136}$

The utopian and ideal society understood in contradistinction to the political and sheltered from it would not arrive quickly enough to protect defenders of the social. The political killed Saint-Just. 
The following two sections, 'Practice' and 'Exigency', examine the four conceptual foci of the natural, the social, the civil, and the political with regard to several areas of policy, practice, and thought: practice contra the ancien régime, institutions of the new society, and goods production and distribution, including finance and monetary policy; revolution itself as is examined in the section on exigency.

\section{PRACTICE}

The Theory of Practice

The Ideal Society in Practice

This section is subtitled 'The Theory of Practice' since what it studies is specific plans and goals of Saint-Just's revolutionary program for France, as opposed to the underlying philosophy of this program and its actualization in an environment of domestic hostility, treachery, and war.

Foundational political action is not necessarily revolutionary political action. But in the case where revolution is the foundational context, one is acting in a relatively chaotic milieu, one where there is opposition to one's political action that is not yet legal or not yet using pro forma channels. Circumstances of exigency such as those Saint-Just encountered are not unique to revolution, but the stakes are pitched much higher, since the attempts being made by revolutionaries are necessarily radical attempts, at least in relation to the status quo. What happens to ordinary practice in the revolutionary situation, or in other situations that might be described as exigent, is that practice becomes theoretical; that is, it takes a step 
backward from actuality, and must remain sidelined in theory, unable to emerge until the obstacles to its establishment are overcome. One salient example of this is Saint-Just's experience with war and force. This experience, like others, such as the experiences regarding the national economy, struggles to emerge as such, exigent circumstances forcing it variously back into the theoretical and then out again into actuality. In such contexts, practice can become the mediate zone between the contexts of the purely theoretical and the realm of pure action, as it did for Saint-Just, since his view of revolution was that it was a temporary correction necessary to bring about proper practice. Practice then can be conceived of as imminent or impending, so long as revolutionary exigency is the context of the implementation of ideas.

Hence we have a new understanding of practice, or at least the place of practice, and this understanding is the understanding we obtain from looking at practice, one might say, through a revolutionary lens, through praxis. Is Saint-Just then the first great exemplar of modern praxis in the traditional political realm? This work, while recognizing the relationship of his life and work to the development of Hegelianism and Marxism, attempts to not apply anachronisms to Saint-Just. Saint-Just exists both inside and outside this tradition, but he is certainly an exemplar of August Ciezkowski's idea that the antipodes of thought and action would come together in a Hegelian synthesis, which idea led through to Karl Marx's idea of praxis, and in turn to its further elaboration in Antonio Gramsci and others. Or rather, in Saint-Just's life, this struggle of antipodes is present to some remarkable extent. The struggle is evident in an equivocation represented on the one hand by Saint-Just's express disparagement of theory ${ }^{137}$ and on the other by his persistent, abiding attempts to bring theory into actuality. 
And in the end, to what degree will contravention and opposition bend and shape this practice which is attempting to establish itself as political normalcy? The experience of the Cult of Reason and Cult of the Supreme Being is a good area for examination of this question. Aulard sees the force of these counterrevolutionary actions and circumstances as formative for these cults:

J'espère que cette essaie historique......montrera dans le culte de la Raison et de l'Être suprême.......la consequence nécessaire et plutôt politique de l'état de guerre ou la résistance de l'ancien régime contre l'esprit nouveau qui avait jeté la Révolution. ${ }^{138}$

Part of what is in question and at stake here is the value, place, and function of political philosophy insofar as it involves ideals. And what would a political philosophy be without ideals, even if these ideals are not named as such? Such a non-ideal political philosophy might be said to be purely descriptive. But is description philosophy? Where is the separation between theory and description? Description also can be grounds for ideals, as when descriptions of Spartan life available to the educated person in eighteenth century France became, as they did for Saint-Just, fodder for an ideal.

Description of Saint-Just's ideal government in practice properly focuses on his program of institutions, which is laid forth in the Fragments. Herein Saint-Just shows proof that, try as he might have to bring theory into practice, the problems he encountered in doing so have already moved back to inform the political philosophy of institutions. Saint-Just clearly has incorporated his experience with the factionalization of the government, which he sees as a profound impediment to its operation, into his plan for institutions, stating that it is these institutions that will forestall the development of factionalism: 
qui sont impassibles et à l'abri de la témérité des factions. ${ }^{139}$

The Constitution of Year I is also ideal for an examination of theory in relation to practice, especially when the third category of exigency is added since, again in this circumstance, practice becomes theoretical, with all actualized practice taking place under conditions of exigency, or revolution. Saint-Just's political integrity is perhaps here most obvious. He brings forth clearly in his speech to the Convention ideas that are present in his theory, whatever its state at that point, ideas such as "L'état social est le rapport des hommes entre eux; l'état politique est le rapport de peuple à peuple" which appear verbatim in his Du Droit Social. ${ }^{140}$ The reasons why many of Saint-Just's ideas were not actualized are many, and include the fact of his early death, the almost immediate modification of the government after his death ${ }^{141}$, and the exigent circumstances themselves, which forced a politic of stabilization and continuation of the revolution to the fore. Though it was probably the greatest republican constitution ever written, the Constitution of Year I was never put into practice, and thus remained, like other of Saint-Just's practical ideas, in the realm of theory. The theoretical components of the three elements of the study of this Constitution as it is presented here are to be found in Du Droit Social ${ }^{142}$. The practical element of the experience of the Constitution can be said to be found in Saint-Just's Discours sur la constitution de la France, where many elements of the Constitution are laid forth ${ }^{143}$. The elements of exigency lie in the realities that prevented the Constitution and so many of Saint-Just's ideals from realization. While the Constitution of Year I is valuable for an examination of Saint-Just's institutions, he expressly set out to establish and defend these institutions in the Fragments, a work that was, like this constitution, stillborn, yet in a more dramatic way. ${ }^{144}$ 
Was the general will state in its spirit then an impracticable idea in its letter? Is Louis Saint-Just the practitioner par excellence of Rousseau's political philosophy? Is he merely such? These questions run through the minds of those who examine Saint-Just, and valid distinctions have been made between Saint-Just's theory and Rousseau's, distinctions such as those made here. ${ }^{145}$ Certainly Montesquieu is an important influence also, as is Lycurgus. But with the latter, there is the sense that his importance for Rousseau might have been an important source of his valuation by Saint-Just. ${ }^{146}$ In the end, Saint-Just's existence as the implementer of a Rousseauian political philosophy must stand as one valid understanding of Saint-Just, though, as with any complex person, not the only one.

Rousseau, in On the Social Contract, states that establishing right by actions (acts) makes tyranny more likely than if political right is established first by political thought. Even if the totality of Saint-Just's written works, speeches, and actions militate toward a conception of the production of political philosophy that calls into question its traditional ordinality, Saint-Just himself offers much evidence that, perhaps with awareness at some level of Rousseau's opinion here, he continued to attempt to see theoretical principles as prior to practice, at least in the practice of foundation: "Avant de traiter d'une division propre à la France, je dois établir les principes; les conséquences s'établiront ensuite d'elles-mêmes, "147 begins Saint's Just's speech having to do with the elements of the Constitution of Year I. And yet, many scholars have felt that the political circumstances were shaping Saint-Just's theory as it developed. Alain Liénard writes of Du Droit Social:

Le cours de l'histoire a bouleversé les beaux rêves d'équilibre. La constitution de 1791 n'a pas survécu à la mauvaise volonté et au sabotage permanent de la cour. Et il est vite apparu que l'attachement à cette constitution devenait contre-révolutionnaire. Le repos auquel elle incitait était mis à profit par l'aristocratie pour préparer une contre-offensive 
d'envergure. Il devient donc nécessaire de trouver un autre système et de lui procurer un solide fondement théorique. C'est dans ce cadre qu'il faut comprendre [Du Droit Social $]^{\prime 148}$

And thus there is, in Saint Just's own words and actions, this equivocation with regard to the production of political philosophy and with regard to both its value and its essence. Even as the evidence suggests that Saint-Just consistently attempted to bring theory into practice, there is also in his statements a disparagement of the former. In the Speech on the Constitution of the Year 1, Saint-Just is critical of the irrelevance of the body of written public law, a body built up by theoretical legal traditions, criticizing its irrelevance and pointing to the problem of application, an important problem to which the public law and its theorists have not attended. ${ }^{149}$

Saint-Just as Legislator

Suppression of the Ancien Régime

Expression of the Idea of the Natural Within the Area of Policy

In his Speech on the Constitution of Year I, Saint-Just seems to strike out against theory when he repeatedly states that the constitution must be a strong one, and must consist not of precepts but rather of laws. However, he wrote political theory which was a foundation for a polity, and the Speech on the Constitution of Year I is parallel to parts of Du Droit Social.

Precepts are not always the product of reflection of the type done by political theorists. 
Saint-Just's political theory though does aim to provide such precepts and yet such precepts would not be the layer of political wisdom appropriate to a state's constitution. The practical guarantor of the peace and harmony of the state must be in something more specific, in laws. These laws though do rest on precepts derived from theory, but the experience of Saint-Just calls into question the origin of the theory itself, indicating that theory might be more or less an articulation of social relations, and yet there is further complexity in that these social relations can become perverted, such that revolutionary political action and theory are necessary to bring back natural social relations.

The corrective revolutionary action in the form of defense and foundation is what is needed in order to promulgate laws that will bring social relations back into alignment with nature, in its political-philosophical conception in Saint-Just. The ideal behind this correction seems to leave Saint-Just longing for the eventual disappearance of the law, or its diminution. After making repeated points that have to do with the importance of having a government of laws rather than of people in the Speech on the Constitution of Year I, the Saint-Just of the Fragments, even while affected by the problems he experienced with implementation of ideas which were translations of the social relations, is again more idealistic, and longs for the Rousseauian minimalism of law: Il faut peut de lois. Là, où il y en a tant, le peuple est esclave. ${ }^{150}$

The inclusion of nature by Saint-Just in his political philosophy even while his revolutionary work otherwise attempted to dismantle the ancien régime, the basis of which was a theory of natural law, is comprehensible in historical context in what at first appear to be two ways. One of these is, as mentioned, its comprehensibility as an historical moment in a movement away from the concept of nature. A second is in a dehistoricized comparison of modern ideas of natural law to premodern conceptions. If we take up the first of these 
though, the second becomes quickly subsumed by its interrogative in that we can argue that the forces of production affect the base of ideas and create shifts in the terrain of concepts such that, with the development of modern ideas of natural law, there is an inevitable negation of these which persists in the older forms which, in Hegelian terms, is representative of a contradiction that was already present in the natural law tradition. Social and critical theory have connected the ideation of the natural to the particular state "in practice" as it existed in eighteenth-century France, a state of feudalism, and this state of feudalism is the characterization of the ancien régime from the viewpoint of the practical, material, and historical. $^{151}$

Is it possible then to connect Saint-Just's theoretical work to his ideal state in practice, the state that was still to trace its origins in nature but also reject the ancien régime in theory and practice? The question should really be put more as whether or not the state of practice as a stage in development can be connected thereto. Aptly, Steven Vogel describes Theodor Adorno's treatment of nature thusly:

.....the nostalgia for some more 'natural' time - as if feudalism were such a thing - is a clue, not to the character of feudalism, nor really even of nature, but of the social world inhabited by those who feel that nostalgia so strongly. What we see in nature, Adorno argues...... similarly says something more about the social than about any (unknowable) nature in itself. 'In every experience of nature', he writes....there is actually present the whole of society. The latter not only provides the schemata of perception in general, but also establishes ahead of time through contrast and similarity what will count as nature. Thus, the experience of nature is constituted by means of determinate negation.' In this argument the mediated character of 'nature' is taken quite seriously: we use our experience of (necessarily mediated) nature to learn something about mediation.... ${ }^{152}$

The specific experience of the mediation of the conceptual within theory, as, for example, a modulation between ancient and modern conceptions of natural law, can then also inform the idea of practice as a type of action in the sense that it can be seen 
in relation to theory as an intermediate, or mediating stage between the more purely theoretical and the more purely actualized, within a process of actualization. SaintJust's "practice" is thereby understood as remaining theoretical in the sense that it is both theory and action that has come up against obstacles in the form of resistance by the forces of the ancien régime, and in this way is a mediative zone between theory and action which is created both by the conceptual and theoretical legacy of feudalism and its apologists and antecedents, but also by their parallel resistance to both conceptual movement of the natural to the social and to the actualization of this theoretical shift.

Expression of the Idea of the Social Within the Area of Policy Suppression of the Ancien Régime

Saint-Just separates the social from the political in more than one way, and makes the social central to human collective life. Insofar as Saint-Just stands as a moment in the historical development of the idea of the social in its relation to philosophy and politics, we might ask what the relationship of Saint-Just's view of the social is to later views of the social which also distinguish it from the political. The question though, posed in this way brings up the problem that Saint-Just himself was not looking at the social as a conceptual category but rather at the specificity of the social as it had existed in historically harmonious societies. Thus, even later terms like 'social revolution' are not used by Saint-Just, and yet he is prefiguring in his theory and action the emergent conceptual terrain.

The filling in of the content of the social, in particular in attempts to distinguish it from 
the political, has been and still is problematic, and has been the ground of significant debates and conflicting sides and schools, all of which, taken together form a problématique, and yet, did Saint-Just perhaps much earlier lay out a solution to this problématique, albeit one unknown to perhaps too many partisans of this debate? The idea of the social as a realm of understanding, as an epistēme ${ }^{153}$ for human community has still arguably not congealed more than two centuries after Saint-Just, the definition of the social as distinct from the political is still in formation. Alfred Cobban points out, for example, the inadequacy of the sociological tradition as a framework for social history, ${ }^{154}$ and in the conflict between conceptions of the social in the Marxist and Revisionist debates about the French Revolution, for example, the social has a tendency to negate the political, and thus clarify an historically emerging understanding of the political as that which is negated, and yet this clarification of the political as it is negated by the social seems to do little to clarify the social in the positive sense. Albert Soboul, for example, describes the ancien régime as characterized socially by aristocratic privilege and politically by divine right and royal absolutism. ${ }^{155}$ The distinction put in this way is correct and yet seems to beg the obvious questions which emerge in relation to power. Was not aristocratic privilege in the so-called ancien régime, in its aspect as question about human community, a specific question within the conceptual framework of power, force, and authority? Soboul does in fact elaborate the distinction between the social and the political in terms of power and authority:

The Capetian monarchy had succeeded by dint of long effort in depriving the seigneurs of their regalian rights and the nobility and the upper clergy of all political influence. But even though they had become subjects, the nobility and clergy nevertheless continued to enjoy privileges. The seigneurs held on to their social and economic privileges, and their seignorial rights continued to make evident the subjection of the peasants. Socially privileged but politically degraded, the aristocracy never forgave the absolute monarchy for having despoiled them of all political authority. ${ }^{156}$ 
In relation even to later work on the social in the traditional realm of the study of politics and also in relation to the later development of social history, Saint-Just's theory seems both prescient and radical. At the theoretical level, Saint-Just describes human community in terms that are radically egalitarian not because of the results of struggles over power and authority, but because the very basis for these struggles has already been removed, both in actuality and in theory. Whereas later theories of proletarian revolution describe a justice and equality that emerges from the machinations of power, Saint-Just reverses the theory-practice order in his holding theory to a retrospective ideal, so that 'political' action and the process of actualization have some element of the actual in the twofold form as historical antecedents as well as future goal. Theory is the recognition of the superfluousness of force in human community, and also of its attendant psychology of authority and power.

With the radical disappearance of power as the fundament of social right, which power is social right's inheritance from the complementarity of natural right to what can be said to be the civil life of the ancien régime, Saint-Just outdoes later theorists of the social, who have continued to find a basis for the social in relation to the political in forms that are mere vestiges of the political and its psychological basis, which is power. In addition, in SaintJust's giving to the social a conceptualization that is both more radical and more specific than many later conceptions, historiographical and conceptual debates about specific concepts within the social that are related to power dynamics, concepts such as 'bourgeoisie' and 'proletariat', and even 'manufacturier' and 'fermier' ${ }^{157}$ are obviated by their superficiality in relation to a definition of the social which contains wtihin it the potential to transcend the psychology of power. 
In the Fragments and elsewhere, an idea that would, from the perspective of contemporary republicanism, be called the idea of equality is evident. In Du Droit Social, Saint-Just makes express use of the concept of equality, but by the time of the Fragments, unity is more important. Here Saint-Just rather lays the foundation of the ideal social realm, through institutions, in unity. Unity is, in fact, one of the goals of the social institutions and one of the characteristics of the social state. ${ }^{158}$ The social state being a former state to which the society must return, institutions are the means by which the society returns to this state and remains there. This unity, however, retains the egalitarian tenor of republicanism, yet seems to go beyond it to the point where it casts the equality of competition and its attendant disharmony as the residua of the ancien régime. Thus, for example, domestics are prohibited: Il n'y a point de domesticité celui qui travaille pour un citoyen est de sa famille et mange avec Lui. ${ }^{159}$ This particular prohibition flows from the specified goals of the social institutions, some of which are 'putting union into families', 'instilling friendship among citizens', 'stifling criminal passions', 'giving courage and a sense of frugality to men', and 'linking them by noble relations'. ${ }^{160}$

Unity as preeminently important is original in the idea of the social law, which is the law of the state of nature. Though there is a dialectic within Saint-Just's thought that moves between antipodes as his political experience unfolds, and though he is despairing in the Fragments, his ideas for unity are rather consistent. Reflection on the demerits of the ancien régime would have been a part of Saint-Just's political thought from an early stage, and the sense of the primacy of unity which social instititutions could guarantee as well. Already in $L^{\prime}$ Esprit Saint-Just is attacking the idea of hereditary honor ${ }^{161}$, and throughout his career he is committed to antifederalism in order to promote what he saw as the essentiality of unity. Bernard Vinot points up Saint-Just's prescience in this regard, in relation to the federalism of 
the United States, which Saint-Just thought was unwise: "...un régime fédéraliste à l'americaine lui sembler porteur de conflits: Un jour, un état...s'armera contre l'autre. "162

Thus, the push for centralization and way from federalism is another element of the attempt by Saint-Just to banish power and authority from the commonwealth in order to reconvene the condtions of unity. The importance of unity is guaranteed by the civil laws, which are themselves manifestations of the social relations. Integrity as the correspondence between theory and action then must maintain itself both forwards and backwards through several stages of human communal life. 'Political' morality then, as a relation itself, is only a proper relation insofar as nature informs the social, which in turn forms the basis of the civil, the institutions of which realm set up the possibility of the society of harmony, which harmony in turn requires an aspect of unity.

Revolution is then, in one sense a moral corrective, first for the social body as a unit, and then by derivation for individuals. Revolution is this moral corrective since revolutionary action is necessitated when this integrity that runs from the natural to the civil, is corrupted. The relationality of morality as a correspondence then is also not monodirectional, since evolution of a society can presumably occur when the civil laws bring about subtle changes in social relations, which are presumably not corrupt unless they are not derived from nature or not endemic to a species (not of the au-dedans from which the political has been ostracized). Revolutionary action also illustrates the bidirectional nature of morality as correspondence, since it is both begotten by theory (the theorist's recognition) and also creates theory based on actual experience, forming even a rapid dialectic of experience and ideation, with morality capable of being seen as the mandate for their correspondence.

Unity as a bulwark against the intrusion of the relations of power into the commonwealth has its base then both in support from traditional political theory's 
examination of historical precedent, such as Saint-Just's looking at Rome and Sparta, and in the actual lived experience of revolutionary exigency and its resultant mandate that factions be prevented. The prevention of factionalization is guaranteed by the laws, which are elements of the civil state. Thus, the law of Saint-Just's Constitution of Year I includes the following guarantees of unity even within the government:

(Chapitre VI)

(Art. 10) L'Assemblée Nationale ne peut se séparer sans s'ajourner.

(Art. 11) Lorsque l'Assemblée Nationale ne se trouve point complète, vingtjours après une proclamation par laquelle elle rappelle tous ses membres, elle mande irrévocablement à la place des absents sans cause légitime autant de suppléants pris à la suite des trois cent quarante et un, dans l'ordre du recensement général; tout remplacement s'effectue de la même manière dans l'ordre du recensement. Si la liste se trouve épuisée, le peuple est convoqué.

(Art. 12) L'Assemblée nationale ne peut, dans aucun cas, se diviser en comités, elle délibère sur la proposition de ses membres, dans l'ordre où les propositions lui sont soumises. ${ }^{163}$

The attempt to instill unity in the lawmaking body itself is an attempt to keep factions out of government. Just after the drawing up of the Constitution of Year I, Saint-Just again addressed the Convention, in his Speech on the Constitutional Division of Territory, and impugned federated government, the basis of both authority and disunity, and connected such government to monarchies, while declaiming it as unacceptable in a republic:

La division d'une monarchie est dans son territoire; le domaine y est la propriété du chef; les fractions du domaine, soumises à des gouverneurs, sont les points d'appui de son autorité; elles isolent le peuple de lui-même; chaque province a son esprit particulier, et n'est liée aux autres provinces que par la puissance du maître.

Dans la république, au contraire, la division est dans les tribus; et les mesures du territoire ne sont autre chose que la division du peuple. ${ }^{164}$ 
Expression of the Idea of the Civil Within the Area ofPolicy -

\section{Suppression of the Ancien Régime}

The Revolution swept away the civil administration of the ancien régime. The SaintJustian society in practice is more radical than that of the Revolution in general, but the ideal of the revolutionaries is perhaps nowhere better spelled out than in the work of Saint-Just. Can one then infer that, had Saint-Just been able to establish the practical realm of social institutions which his work begins to detail, the Revolution would have had the difficult task of both stabilizing and radicalizing? The civil realm in practice in its particularity is largely the concern of the Fragments, and the severity of some of the societal rules set forth therein is partly the result of the fact that Saint-Just, as a political philosopher and legislator of the Revolution, was responding to what had transpired since the outbreak of the Revolution, such that exigent circumstances also were determinative of the societal norms of the ideal civil realm. In this sense Saint-Just's civil realm as he imagines in it the Fragments and to some degree elsewhere is a civil realm born partly from revolutionary philosophy. The active or action component of the laws being the context of revolution, again here the time line and the ordinal and even substantive relationships between theory and practice can be interrogated.

Though there are many ways to approach the idea of obstacles to implementation as the revolutionary context which creates the category of exigency in relation to the practical, Saint-Just and the other Revolutionaries consistently saw these as elements of the counterrevolution. Taking up the understanding of the Revolutionaries and Saint-Just, and thus the counterrevolution as the exigent aspect of the ancien régime, the resistance to implementation of the ideal civil realm which is largely comprised by Saint-Justian institutions is an indication of the reasons for the aforementioned severity and radicality of some of the apparatuses of social relations in the form of laws and customs which form the 
civil realm. Thus, in some sense the counterrevolution, as that which creates the exigent circumstances which necessitate such radicality and severity, is a force for the establishment of the civil, the more concrete form of the social, just as its analogue, the political, is the force which establishes the social realm initially (See Chart of Relations with regard to the functions of the respective realms). Much of the actual attempt to impede the implementation of the civil came from proprietors and from clergy, ${ }^{165}$ two groups who would be affected earlier than the nobility and the royalty by the Revolutionary program because they would have sooner felt the effects of such policies, standing as they did as buttresses and crossbeams of the upper nobility, the privileged, and the royals. Thus, the central question of the role of active experience in relation to political theory can be asked in the form of whether or not Saint-Just's severe restrictions on these proprietors of land, ${ }^{166}$ and his participation in the complete and radical reorientation of the civil realm with regard to cults as laid forth in the Fragments and as created by the Comittee of Public Safety, ${ }^{167}$ which left the former authorities of the Judaic cults with no state imprimatur, with indirect censure, and with a radically different role under the Cult of the Supreme Being should they choose to remain in positions with some semblance of authority, were the result of the experience of the Revolution and the resistance thereto, or whether they were considered to have validity prior to the Revolution, or some combination of the two. On the one hand Saint-Just, because of his timeline, is a child of the Revolution, since at the storming of the Bastille in 1789 he was only twenty-one years old, and thus one might argue that ideas formed in exigent circumstances would naturally take prominence in his "mature" mind; on the other hand, Saint-Just persistently attempts to hold onto the importance of political theory, whether that theorizing be an ex post facto apologetics or the prescriptive product of reflection. Whatever the origin of such an allegiance to the idea of political theory, the actuality of the experience of the foundation of a society militates to the question of both the relationship between 
theory and practice and the question of the role and nature of political theory. The civil realm is itself in a sense a byproduct of the ideal in that Saint-Just imagines a social realm in which apparatuses of formation and maintenance of the natural social relations might evanesce once their corrective purpose is served, and the political is fully externalized.

Expression of the Idea of the Political Within the Area of Policy -

\section{Suppression of the Ancien Régime}

The political in its theoretical aspect is, in Saint-Just, the world of the au-dehors. This au-dehors that is the world of interstate relations, or the relation of peoples to peoples, is the world in which occur and are found the enemies of the Revolution and of the new republic, and the enemies of this republic's natural social relations, relations born of the world of the au-dedans. In the realm of practice then, these enemies of the Revolution and the republic, who were legitimized under the ancien régime, are delegitimized, but this delegitimization does not mean that they do not pose a danger. Saint-Just persistently connects this danger to the republic from its enemies to this world of the political and the au-dehors, and the government which he is attempting to establish retains this sense of threat from the outside and becomes essentially the guard against it. The Constitution of Year I is built significantly on this idea of the holding the political at bay:

La Constitution des Français doit consumer le ridicule de la royauté dans toute l'Europe, en la montrant dénuée de mission, de représentation, de moralité; elle doit être simple, facile à établir, à executer, et à répandre. ${ }^{168}$

In the idea of the facility of the communication and expansion of the Constitution is the notion of yet a further diminution of the political, since Saint-Just seems to indicate that the Constitution's exemplary nature will be evident to the rest of Europe. The statement above 
then seems to universalize the idea of the displacement of the political, implicitly putting forward the notion that the mistaking of political relations for social relations is something that has occurred elsewhere, and not just in France, and that the Revolution in France and the type of government it inaugurates will serve as exemplar and instantiation of the real possibility of a more universal ordering of relations such that the social relations that properly comprise a human community are maintained, thus maintaining peace and harmony, and turning back from savage civil society toward nature again, in France and elsewhere:

Bientôt les nations éclairées feront le procès à ceux qui ont régné sur elles; les rois fuiront dans les déserts, parmi les animaux féroces leurs semblables, et la nature reprendra ses droits. ${ }^{169}$

Here then we have evidence that Saint-Just, who emphasized patriotism and focused very much on France itself, had in mind a universal liberation in the form of the removal of the political and its relations, the improperly placed relations between persons which had characterized the ancien régime, from their false placement onto social relations in societies all over Europe and beyond. The laws of the republic then, and its civic practice, are repudiative and liberatory, and also tend toward the universal.

Consistent with this view and the other work of Saint-Just then is the idea of multiple circles of the social, or multiple nations, with the space of interaction between the various circles comprising the political. In the modern nation-state system, the political is the realm of the international, and one might be led to infer that the cosmopolitan would automatically be suspect. In actual practice, the Revolutionary War was consistent with Saint-Just's idea of the protection of the au-dedans. The unfolding of the war in its actuality is entirely consistent with Saint-Just's understanding of the political. The ancien régime, which was a state of political relations, could include outside force, such as Austrian troops and Italian counterrevolutionaries, since its social element was already corrupt. The international effort 
against the Revolution then comported with the internationalism which might logically result when political relations form the social psyche. American views and involvement must have also seemed to Saint-Just consistent with his theory of the social and political, since the Jacobin thought of the Committees rejected even most sympathetic American views on the Revolution, as manifested in the criminalization of the Marquis de Lafayette and Thomas Paine, two figures of the French Revolution who were also of mixed citizenship. Since the ancien régime understood broadly was the repository of the political, its consolidation in the exterior was a practical mandate.

Institutional Foundation, Organization and Maintenance Expression of the Idea of the Natural Within the Area of Policy

Saint- Just writes that "Les institutions ont pour objet .....de rendre la nature et l'innocence la passion de tous les cours..." 170 The fluidity of Saint-Just's thought, and its progression, are apparent in a comparison with his earlier words in the Speech on the Constitution of Year I, where he asserts the firm need for law. The need for law however is only a need to the degree that social relations have been attenuated by the political. Thus, as one moves away from the political and toward nature, one moves away from law and toward justice (See Diagram 3). The French Revolutionaries were known for distrusting the law and 
placing justice consistently above it, noting the law's injustice and deceptions. ${ }^{171}$ Saint-Just's political philosophy, in accordance with this view, places law in the role of something denatured, something lesser than justice, and something which is historically pathological with regard to the human species: "L'homme social est un être simple, ami de son semblable, l'homme sauvage ou politique est un animal cruel. La force de la loi le dénature, et l'arrache à soi-même. ${ }^{172}$ As we will see below with regard to force itself, the laws, the civil manifestation of force, are seen as something that ideally will disappear altogether as the polity realigns itself with nature.

\section{Diagram 3}

Less Ideal $>$ More Ideal

\section{Political}

Social

Natural

Law $\rightarrow$ Justice

The ultimate result of force's existence in the social realm, the au-dedans, had been despotism, and this resulted from the social's usurpation by relations of force unnatural to it. Here Saint-Just is effectively answering the question posed to Rousseau's political philosophy, "Can the general will be wrong?" in the affirmative, since somewhere along the line historically, the people had "lost their taste for assemblies" and harmonious social relations had become corrupted. His implied answer, like Rousseau's, is more precisely, that the general will can actually never be wrong, but that certain particulars within the polity, or even the people as a whole, could be mistaken about it, or misrepresent it. But how can this 
misrepresentation come about? In Saint-Just's work there is the idea that this came about when sovereignty became displaced, possibly when there was a loss of appreciation for the social relations which governed the body of the people. Though, as in Rousseau and others who formulate social anthropologies as conjectural premises, there is uncertainty here with regard to the historical loss of unity and of the social state, and yet the important idea comes through to us that relations of force must be spread out and then driven out of the polity through institutions, whose foundation is only possible via revolutionary action.

Saint-Just, perhaps because he had less time, spends less time than Rousseau or Kant elaborating a historical process or chain of events by which people in societies lost something natural and authentic, in this case when the political invaded the social and altered the civil state, so the process and causes of the people's loss of touch with the social remain, as in Rousseau, unelaborated. In Saint-Just's work though, nature is most often used as the standard by which something is made inauthentic, though again here, it would seem not to be necessary as a conceptual category that serves as a criterion of corruption or inauthenticity. Delusion and self-misunderstanding are present to be sure when a people goes astray from the social. The important process in the theory of Saint-Just is a future process wherein the kind of institutions Saint-Just has in mind, which are significantly institutions of the heart, whether or not they be institutions with manifestations in brick or stone, will continuously translate and inculcate the values derived from natural social relations so as to prevent future misalignments of the prince and the sovereign and the ultimate result of these, despotism: "Le despotisme se trouve dans le pouvoir unique, et ne diminue que plus il y a d'institutions. ${ }^{\prime 173}$ These institutions will ensure the correct understanding and living of the social law, the harmonious operation of social relations so that the people do not again become delusional: "...le despotisme ....n'est que l'illusion des esclaves"174 So, nature is tied 
to reality, and a to a clear view not so much of what social relations are, but of what they are not, we might say of what is unnatural, and thus institutions are ultimately in the service of this continued alignment of the people with the sovereign, of the social and the civil, all of which is really a self-realization that has as its constant guarantor the institutions of a well founded state. Ultimately though, these institutions are the social itself, and thus the state completed and having reached its harmonious end is for Saint-Just first the alignment of the institutions which the Revolution was establishing with the social, the very social they were both begetting and becoming, and then this social's alignment with nature, which here also, is both begotten by and proceeded to by, the social. The Revolution then is, in some important sense, a corrective of historical development consistent with Rousseau's twofold idea of nature, which is discussed above. So, the complex but uncertain and equivocal view of nature in Rousseau then finds its way into Saint-Just even as Saint-Just insists that the law is not the effect of the general will, but rather only "les rapports naturels". ${ }^{175}$

The social in Saint-Just is partly defined negatively with regard to the political but can be said to be defined positively with regard to nature in a way that makes the social and the natural mostly coterminous and calling into question the value of the natural distinction, placing it as residuum of the Rousseauian legacy. One way in which the social is understood in relation to what Saint-Just considers the natural is temporally. In the Speech on the Constitution of Year I, Saint-Just critiques the Rousseauian conception of the social contract by questioning a historical timeline of development, the interpretation of which for him must always remain 'natural': "Quelle langue parla-t-il a des bêtes qui ne communiquaient point? Et si elles communiquaient, n'avait-il pas précédé de longtemps l'ordre politique?" SaintJust's idea of a natural order with historical-anthropological aspects though, shares Rousseau's ambivalence about nature, since processes which develop which are malignant to 
the social state develop not entirely unnaturally, but only end up in a state that is unnatural.

This uncertainty in the original ideal then, already present in Rousseau's idea of nature, can be seen to lead to a questioning of the essence of right, placing before us the possibly of the social as the basis of right, which placement itself may be only didactic and intermediary role in a historically changing understanding of human community. This uncertain role as evidence of dialectical mediation has its corollary in the placement of right within the realm of practice, itself a medial concept in its relation to revolution. The uncertainty then that is necessarily a part of the original ideal and can be considered a dialectical tension in a historical process of mediation in the understanding of developments and has as its logical and thought-system aspect a mediation between the analytic and the synthetic, is specifically with regard to Saint-Just, a portal to problems in the interplay of the actual and the theoretical, since a long and subtle historical process of deviation would be difficult to detect and arrest. This, though, is the work of social institutions, which are designed to prevent the development of such deviations in the form of usurpations of the social by the political and the resulting corruption of the civil state, which then has the potential to create corrupted (political-social) relations.

The avoidance of long and subtle deviations from what for Saint-Just is a natural social order lends support to revolution as 'political' action, since the rapid purification of the social realm prevents the abuses inherent in liberal reformism, which historically allowed in mysticism ${ }^{176}$, the cover behind which all sorts of contraventions to the proper social order had arisen. Thus, Saint-Just's experience points to another element of revolution, and that is its presumed superiority to reformism in preventing deviation and detractions from the social order, which for Saint-Just is natural. 
Expression of the Idea of the Social Within the Area of Policy -

Institutional Foundation, Organization, and Maintenance

Saint-Just's idea of and emphasis on institutions was, importantly and more specifically on social institutions. When Saint-Just refers to institutions, he is first referring to something like values and customs, and additionally to the specific organizational apparatuses which will establish, maintain, instill, reinforce, and promote the valuation of these customs and values, which later comprise the civil state. There are perhaps two reasons for the relative lack of specific prescriptions for and descriptions of these institutions as organizational and administrative apparatuses. One is the exigencies of the Revolution, which demanded time spent on organizations concerned with the maintenance of the revolutionary government itself, and another was that Saint-Just was attempting to lay forth the general bases of society, but not all of its specific content.

The idea of social institutions, like many of Saint-Just's ideas and concepts, has seemed to float through discourses of the social, such as that of sociology, without appearing to be always fully developed. Saint-Just though, radically and presciently, fills out the idea of the social institution with the practical particulars of the Fragments. The value of the concretization of the theoretical is not necessarily or only in particulars of the institutions of the Fragments that seem variously Spartan, French provincial, radically progressive, and even, avant la lettre, Victorian, but rather in the process of merging the roles of theorist, legislator, and revolutionary, such that the social acquires a validity across the spectrum of what is known as human political experience. However, this does not mean that particularities of the social relations as Saint-Just attempted to legislate them, relations which 
comprised the social realm in practice, might not be centrally important in the type of state that they create, and in their portent for future states, even in their conflicts. Of what consequence is the supreme importance of friendship in Saint-Just alongside the sacrosanctity of traditional marriage? Spouses are celebrated and marriage is encouraged, but, what would a social bond that sanctifies friendship look like? Saint-Just writes, "Nul ne peut contracter sans le presence de ses amis, ou le contrat est nul,"177 and, "si un homme quitte un ami, il est tenu de rendre compte au peuple, dans le temple, des motifs qui le lui font quitter."178 The particularities of what revolution brings about then are the result of an attempt to fuse Spartan institutions with those of modern France and its legacy of customs, but also an attempt to bring the spirit of the Enlightenment into laws that guarantee the complete freedom and equality of all formerly enslaved and colonized persons, and the control of women over their person and contracts and their freedom from obligation in marriage.

The idea of the social as existing within an au-dedans, a presumably non-cosmopolitan circle of protection, would seem to seek stasis in a world that is a mélange of regressive and progressive social ideas, while the revolution that is to bring about the social in practice is itself radical in its action. The question thus arises as to the evolution of the social state, as to how institutions might change over time. Would the radicality of the break with the past as an experience in social memory begin itself to exert pressure for further change on the social relations of the au-dedans, even if the au-dedans is kept pure? The working out of a society in practice via the newly established social institutions would itself be a monumental idealist project, and the outcome of the mélange of particulars within the social realm is as exciting as it is hard to predict, and contains within itself the potentiality of being a prototype of a society that moves toward classlessness. This portent has continued to characterize the social 
as it has developed after Saint-Just and in this way alone Saint-Just's prioritization of the social combined with his attempt to make it practical gives the social in some sense a hidden history of some greater particularity than its amorphousness in later discourses of the social would indicate had previously occurred. The question of the development of the social after Saint-Just and heretofore though can still ultimately be understood in some important sense in its removal from the practical level, that is, in its removal from the materially prominent and unobfuscated circumstances of the potential proletariat, with this removal being the same as those circumstances as understood by the bourgeoisie as the class which becomes partly defined in its emergence as the class of the idea of representation par excellence: Je n'ai confié à personne mon dessein génereux et je n'ai vu que vous, représentants du peuple souverain, qui fussiez dignes de mon sacrifice. ${ }^{179}$ The social remains today in this bourgeois mode of understanding in the sense that even social history, as a later moment in the conceptual trajectory of the social, remains a history largely written and developed by the scholarly petit bourgeoisie, even though its subject matter is the life of the proletariat.

\section{Expression of the Idea of the Civil Within the Area of Policy}

What is it that is needed by human beings in the ideal civil society? Saint-Just's sketch for the institutions of France in the Fragments lists two expressly civil institutions: institutions of education and institutions of friendship. Friendship requires some unity of thought and sensibility, and the organization of the civil realm was to be in accordance with the need for unity, a unified and centralized one, and not the organization of a federal polity. Consistent with his antifederalism was Saint-Just's desire to spread out the elements of force and control so as to allow the natural social state to form, or reform. Civil institutions were the practical way to maintain the social relations which properly constitute a society and to 
establish this reformation. The social is ultimately the ideal of a society without law: "Il y a trop de lois, trop peu d'institutions civiles. ${ }^{180}$

Institutions themselves were really the constitutive element of the civil in the stillborn republican state as it would have existed under the Rousseauian Constitution of Year I, and this state was, at least at that point, conceived of both rhetorically and philosophically as a Rousseauian general will state in which one will, made up of particular wills, would form the social bond, which would then in turn, as Saint-Just's political theory has it, be maintained by the social institutions which constitute the civil realm. The new republic being a general will state, unity would have to inhere and thus, even prior to the later centralization demanded by the criterion of unity and required by exigencies, a revolutionary unity which was exhibited by the Committee of Public Safety after Saint-Just became a member thereof (May 1793), a unity of the entire people had to be established institutionally. The disunity of federalism would not guarantee and perpetuate the rule of the social. In fact, in the Speech on the Constitution of Year I, Saint-Just's words portend a not too distant calamity in the form of a total loss of the social will which the Revolution was working to establish and guarantee: "Si la République n'était point renversée, il s'établiraient sous vingt ans un patriciat avec un conseil de ministres"181 This loss was linked to a legislature that was federative due to its being comprised of representatives elected by district rather than by the people as a unified body. ${ }^{182}$ Federalism then was increasingly seen as a danger to the nascent republic by not only Saint-Just but those of his political ilk, especially by many members of the Committee of Public Safety ${ }^{183}$, to which he was appointed approximately one month after his Speech on the Constitution of Year I. However, the Constitution of Year I never took effect, and federalism continued to present itself as a threat, with Saint-Just and others having to take continued revolutionary measures to stave it out of the government. 
The social law being ultimately something more like justice than law (See Diagram 3 above), its establishment via the institutions of the civil state requires a unity of the social bond. Therefore, division of the sovereign via a federative representation will not serve the end of social law, or justice. We can add then to the previous diagram of justice and the law (Diagram 3) the unification of representation by the establishment in the constitution of election of representatives of France by the people altogether, no matter where they reside. Thus, the analog of the progression of law to justice (civil to social) is progression from departmentalism to the idea of one undivided society with regard to representation. As even law is dangerous in that it can deviate from justice, representation itself is also dangerous because it is a separation from the sovereign. In order to allay this threat, Saint-Just places the persons in the office of representative below the level of the citizen, the member of the sovereign body. One can see in this placement Saint-Just's awareness at some level, of the class problems inherent in bourgeois notions of representation.

\section{Expression of the Idea of the Political Within the Area of Policy}

On 8 Pluviôse of Year I, Saint-Just addressed the National Convention in a speech on the question of the organization of the Ministry of War. Emmanuel Joseph Sieyès had submitted, on behalf of the Comité de Défense Générale, a report on this organization. ${ }^{184}$ Saint-Just agreed with a portion of Sieyès' recommendations, but fundamentally disagreed about the placement of the ministry and its oversight. His words on the ministry are in perfect accord with his political philosophy, and demonstrate clearly his attempts to remain allegiant to his fundamental political ideas, which demand that the political be kept separate from civil life, that force be kept out of the internal government, and that all accountability be connected closely to the people, in this case through their representatives in the legislature, 
the National Convention: "Mais la guerre n'est elle point un état violent, et l'administration de la guerre doit-elle faire partie du gouvernement intérieur permanent? Je ne le crois pas." ${ }^{185}$ and, "Le peuple n'a pas d'interet a faire la guerre."186 Saint-Just tries deftly to balance the desire for separation of powers within the government, which had been relevant to this debate, with the need to keep force, the province of the executive branch, out of the internal government. In so doing, he expressly states that the legislature is the primary power in a proper state; to wit

...lorsque, dans une grande République, la puissance qui fait les lois doit être, en certain cas, balancée par celle qui les exécute, il est dangereux que celle-ci ne devienne terrible, et n'avilisse la première, puissance législatrice..., ${ }^{187}$

and diminishes the power of the executive:

La puissance exécutrice trouve dans la guerre l'accroissement de son crédit; elle lui fournit mille moyens d'usurper. C'est pourquoi mon dessein serait de vous proposer que le ministère militaire, détaché de la puissance exécutrice, ne dépendit que de vous seuls... ${ }^{188}$

In reality, Saint-Just would like to go further in the putting into practice of his philosophical ideals, and eliminate force altogether, and with it the political, from social interaction, but the circumstances at the time, that is, the exigencies of the day, would not, he thought, allow this. In Du Droit Social, he had even written, "Si l'usurpation intérieure ne sort jamais que du magistrat, un peuple qui n'a point de magistrat ne peut être usurpé," presenting the idea of sweeping away the executive, the repository of force. The inability to prevent war had countermanded proper practice and pushed a second order, an order of exigency, into the circumstantial fore. In Saint-Just's ideal state, both in the au-dedans and the au-dehors, there is even no political element left at all. The attempt to keep the Ministry of War accountable to the legislature directly can then be seen as once removed from ideal practice, or from the 
theory of practice, and as occupying the realm of exigent political action, war itself being an emergency, and the revolution itself being an emergency political situation. Despite this allowance for circumstance, Saint-Just, in his accounting for how actual military operations would be carried out without the cumbersome attention of the legislature to their details, lays forth the basis for a future severance of relations of force, of severance of a state from the political domain altogether: “ La direction du pouvoir militaire (je ne dis pas l'execution militaire) est inalienable de la puissance legislative du souverain..." ${ }^{\prime 89}$ Thus he is here separating, as much as the exigencies of the day would allow, force and the political from society, dividing the oversight of the military in order to do so and explaining this division in this way.

In the Speech on the Constitution of Year I, the theory and practice distinction is inherent in the social, which is itself significantly defined negatively, as against the political. Article I of the Constitution as laid forth in the speech reads: "Tout peuple chez lequel l'exercice et la garantie [des ledit droits et devoirs] n'est pas le principe de l'ordre social, n'a point de constitution." 190 The exercise of rights and duties occurs in the realm of action, which is at least initially informed by theory, while their guarantee, in a society without force, is in the law and in institutions, which are formed from theory, which theory in turn has origins both in the actual and the purely theoretical. This negative definition of the social however, has more than one aspect, and does not only occur in the removal of the political to the au-dehors.

Another aspect of the separation of the political and the social in Saint-Just is the refusal to allow power to be an aspect of the government, even in the au-dedans, the realm of the law of social relations. The political in its traditional sense of the relations and management of power is kept out of the social realm then not only by the attribution of the 
political to the world of the au-dehors, but also by the delegitimization and denigration of government in its personal aspect, that is, of persons as part of a government that can in any way be demarcated in relation to the people. Saint-Just insists on purity. This purity consists in keeping the sovereign always synonymous with the people, and the people, the locus of the social relations which are a society, is separate from 'the magistrate'. That is, the people are separated from those who take on government roles by a difference in level of authority and sovereignty. In the Speech on the Constitution of Year I, this idea is put thusly: "Les représentants du peuple, les magistrats, ne sont point au-dessus des citoyens. La subordination établie pour l'harmonie du gouvernement n'est pas préeminence; toute puissance est dans les lois...." ${ }^{191}$ Elsewhere, as mentioned above, Saint-Just takes this idea one step further and actually places government officials beneath the citizenry, beneath the level of the fully legitimate social relations which have replaced power and which have replaced the political as the template for collective human life. The wording of the 'Essai de Constitution' within the Speech on the Constitution of Year I is somewhat milder than the words of Saint-Just just a month before his presentation to the Convention when, in a speech to the Jacobins, he said, "... je n'ai pas trouvé un seul homme de bien dans le gouvernment, je n'ai trouvé de bon que le peuple." ${ }^{192}$ Thus, it appears to be actuality which has informed if not largely created this reprimand of the traditional political in a second sense. Action, or actuality as its aim, and theory actually combine here and conspire to keep the social pure, which in this instance means free from what has formed an essential part of the historical trajectory of the political in its democratic line, the legitimacy of persons as representatives with autonomy. This appearance of the political in the form of personhood is expunged and government 'officials' are functionaries not of the general will, but of the interplay of social relations, which social relations are relations of sovereignty, which resides only in the people directly. 
Thus, the imprimatur of legitimacy for a human community remains in some sense less ethereal than it would be in a purely Rousseauian society, because social relations also have some predescribed and specific content which corresponds to the role of theory, that content being based specifically in institutions such as friendship. Importantly, the relations of power, relations of the political that is, though they set up the society initially, do so by society's formation in contradistinction to them, by this society's negation of these relations and its sealing itself off from them. Relations of force are in this manner removed from the $a u$ dedans by the internal guarantees of the removal of the ability of power-as-force to legitimize, guarantees such as social institutions and the social bond. The delegitimization of the political is then an operation of the state, though in Saint-Just, Lenin's later notion of the withering away of the governmental state ${ }^{193}$ after a utopian (communist) state is achieved is already present, even while in revolutionary exigency the state is actually strengthened. The "state" as one can envision it in Saint-Justian practice, is the life of the persons in a society as it is formed and maintained by social relations which comprise this life, which social relations are established or reestablished and maintained by institutions as vigilant guarantors of the social circle's insularity from the political. The revolution's bringing about of a revolutionary state apparatus is really then the intermediate creation of the apparatus of a modern nation state and a negation of the state of the ancien régime, but this creation of a revolutionary state apparatus, at least in the theory of Saint-Just, is only brought about to serve the recreation of the "state" of social relations, which is the Saint-Justian society in practice. In this way Saint-Just's "state" is akin to the later Leninist idea of a society in which the apparatuses of power-as-force have largely disappeared. Lenin, discussing Friedrich Engels, writes: "The state in general, i.e. the most complete democracy, can only 'wither away',"194 and in this Saint-Justian society in practice, the gradual disappearance of the political as social relations are reinforced by social institutions, is akin to the 
disappearance of the state in some sense, though not necessarily in every sense. The concept of the state after the removal of political relations and relations of power may look different than the corrupted modern-nation state's apparatuses of management, representation, and control, but may nevertheless have some formal existence in a new sense. The Saint-Justian society in practice then is not necessarily anarchic with relation to the state as it is commonly understood. ${ }^{195}$

The relentless fight against what Saint-Just understood as the political was intended to be the duty of social institutions after the Revolution. Once the political was removed to its proper domain in the most direct and crude way, via international war, the focus could turn presumably to the interior, and to the establishment of the society of social relations in its internal functioning. The intermediary of the government, which in a sense stood between the exterior political and the interior world of peace and harmony, was kept subservient to, and beneath the people in a hierarchy which stretched from politics, across the civil and social realms, to nature. The interior civil life with its principle of equality was radically egalitarian with regard to class in its actual policies, though Saint-Just did not, in general, adopt class rhetoric. The social realm which existed prior to the civil and yet within the structure of the civil as derived from the social was the realm of independence, the realm where individuality would exist and be represented, albeit a communal individuality that cannot be accurately described as liberal. The radical egalitarianism of the Saint-Justian policies of the Revolution and those created for the social state in the writings of Saint-Just clearly radically alter class in society, and this alteration is significantly toward radical egalitarianism, even as the degree of political involvement of the people's governors and representatives might be taken as a new class distinction which goes so far as to reverse the 
old order and place the government, in a disparaged state insofar as it must traffic with the political, lower in the hierarchy of society than the body of the people. In the examination of a class analytic and its import for Saint-Just's political life, it should be noted then that the practice aspect of Saint-Just, which remained largely theoretical, connects in some respects more to the ideals of the sans-culottes and other forces in favor of communism than does the portion here understood as exigency, or the exigent circumstances of the Revolution. How is this so? It is so in the sense that Saint-Just's ideal is far more communistic than the politic of the day, the exigencies of the day, would allow. The ultimate vision of a pastoral community of small landholders who hold only enough land for production by the owners themselves and an elimination of interest together alone constitute something not too far removed from Maoism. And ultimately, the relation to us of the portent of transcendence of class in the social state in Saint-Just's practical theory is wherein is couched perhaps his own class transcendence, his own yearning for political philosophy, if political philosophers can be seen as those who make attempts to understand and transcend all phenomena of thought and action, including class.

For Saint-Just then, though he lived and wrote before the discourse of class rose to the fore out of historical conditions, class is clearly of the political, and is itself then something corrupt and alien to proper social relations. The Revolution is the corrective that would provide for the establishment of social institutions which required for their inception some initial practice of class reduction and realignment, and yet whose ultimate ideal would be found only via the continued operation of social institutions, which would function continuously to keep the political outside the realm of the social, the classless au-dedans, which internal realm may not only provide for a practicable idyll of peace and harmony, but may also portend the possibility of a different, more egalitarian possibility for democracy. 
Goods Production and Distribution and Finance Expression of the Idea of the Natural Within the Area of Policy

In the area of distribution of subsistence goods, Saint-Just describes a complete political progression of theory, practice, and actuality. He begins this description of such a progression by saying that, primarily, an ethic or moral doctrine ${ }^{196}$ must be the theory of the laws, the laws being the civil component of the social, before it can be that of 'civil life'. ${ }^{197}$ Whence, then, an ethical system? In traditional political philosophy moral doctrine is considered to be something that is best arrived at by political philosophers in their traditional patterns of removal from active political life, or of temporary engagement and retreat. In practice, the ethical framework of any society has not always been derived or otherwise developed in the manner of traditional political philosophy. If the ethic of a philosopher in relation to the people has other origins, it has been considered improperly derived or developed or ignored. ${ }^{198}$ Saint-Just is in a sense struggling with some ancient understandings of theory and practice: the separation of the two politically by Aristotle and their idealistically impossible fusion in Plato. The idea of what politics and philosophy each are though, of what their essence is, is connected to an idea of nature, which very idea is the $a$ priori for their characterization. The idea of nature as determinative of philosophy and politics is not necessarily contrary to the idea of there being a temporal component of philosophy and politics which is partly and importantly determinative of these in their essence, and yet, with the idea of nature as an a priori, all change in time and space can occur ultimately only within the concept of nature, and thus all ultimate movement is within the concept, which monodimensiality can result easily in philosophical stultification and 
limitation, or its corollary, amorphousness. The action component of Saint-Just's experience is also his stepping away from the concept of nature, and presents the opportunity for a theoretical aspect of life that is only part of an interaction, the interaction between theory and practice as mediation. In the mediation itself, not only does the per se of Aristotle disappear in its describable substantive confinement, but the attempts of action, when taken into the theoretical itself, alter the ideal such that its Platonic possibility may be altered as well. Aristotle's goodness or eudaemonia is derived from the concept of nature, which concept, until modernity's placement of it in historical motion with Rousseau's philosophy, ${ }^{199}$ is a static, fixed, and separate thing. The life of Saint-Just though, and his experience with theoria and praxis are evidence of the historical moment of realization that concepts do not exist as thoroughly delimited and static, but only have an existence in temporal relation to other concepts. Thus, nature may be an a priori standard in a purely temporal sense, but cannot be fixed in its limits, since it is a historical concept that exists in the modern world of Saint-Just only in relation to, for example, the emerging concept of the social in its sense as a supersession of the political. Derivations from the concept of nature, such as politics and theory, change temporally-historically as well, both in relation to nature and in ways that are not directly related to their conceptual derivation from nature. Consequently, politics becomes a product of theory and action, and the Platonic and Aristotelian questions about the subordination of one to the other are superseded by a newer political philosophy that is not focused on questions of superiority, but rather only on the mediation of concepts, which mediation is now the zone of the 'political', a zone in which relationality is a baseline, the zone of the transmogrification of concepts. The 'it' of the political then, is not conceptually stable. In its Saint-Justian moment it exists in transit between the natural and the social, and this transitory existence, which can be seen as a series of 'moments' of the political's existence, occurs in the working out of the relationship of theory and action. Though Saint- 
Just clearly wants theoria to precede praxis and strives to maintain this lineage, contraventions to practice informed by theory force a reversal of this line from nature, but also the entire experience of Saint-Just offers itself up to us as a ground for thinking about questions of this relationship. Most importantly, theoria itself is based in human relationships in society, or social relations, rather than on the contemplation of those partly alienated therefrom.

After giving an overview of the actual situation at the time regarding the commerce of grains in the Speech on Subsistences, Saint-Just returns via the law to the theoretical base of nature, arguing that commerce and laws regarding it have become foundationless or without connection to a moral based in natural social relations. Corollarily, the assignat had to be made to correspond to an actuality and to legitimate needs, and laws that served interstate commercial interests first, or the desires for wealth gained by derivative economies, were not laws born of social relations, the understanding of which relations is moral theory: "Le législateur doit calculer tous les produits dans l'État, et faire en sorte que le signe les représente...... On ne doit pas représenter les fonds, on ne doit représenter que les produits." 200

One must be able to trace a line from nature all the way through all of the elements of the social, the sovereign, the city, or social body, and the king, ${ }^{201}$ which is the government: "Nos subsistences ont disparu à mesure que nôtre liberté s'est étendue parce que nous ne sommes guère attachés qu'aux principes de la liberté, et que nous avons négligé ceux du gouvernement. $" 202$ This line necessarily includes the laws based on social relations derived from nature that would prevent in the first place a state of exigency of the type that France was experiencing with regard to foodstuffs, an exigency which, however, comes back to 
inform the future policy of the state in practice, as Saint-Just conceives of it. The experiences of the problems with the distribution of subsistences thus can be said to educate the developing laws of the emerging state, perhaps such that the duration of the social state, the time before its corruption by the political and its descent into anarchy, can be lengthened. It may be that paradoxically, the prolongation of the revolution may lead to more revolutionary laws, laws that are refined by exigent experience into severity, but this prolongation itself will require the discernment of the legislator to overcome, in that the legislator can remain focused on the creation or return of the society of social relations based in nature, even through the obfuscation:

Mais ce qui perpétue le mal, c'est l'imprudence d'un gouvernement provisoire trop longtemps souffert dans lequel tout est confondu, dans lequel les purs éléments de la liberté se font la guerre, comme on peint le chaos avant la nature. $^{203}$

Thus the legislator as revolutionary must be able to remain tied to the vision of a practical state that is prospective, immanent, incipient; to a practice that is so because of its attachment to an ideal, albeit an ideal that is itself the product of both actual experience and theory, and their relationship in time.

Expression of the Idea of the Social Within the Area of Policy -

Goods Production and Distribution

Despite the interplay of theory and action in Saint-Just's lived experience and its potential as a template for reconfiguration of the political overall, his theory itself must take into account the actuality of the political, even in its new definition. Thus Saint-Just fashions a theory in which the political is in some respects a corollary to the nation-state and its society, the international system. In terms then of the need to protect the au-dedans from the 
political, which political consists inherently of foreign nations and their citizens and employees, the notion of a closed society is relevant. ${ }^{204}$ The closed nation-state in which social relations could return to their natural inceptualization was not only closed in actual political practice but rather there is even closure in the realm of international relations: "J'ose dire que il ne peut exister un bon traité d'économie pratique. Chaque gouvernement a ses abus....... ${ }^{\prime 205}$ This theoretical justification is universal, stating that all societies have their own social relations and that the extrapolation of these to the exterior, to the world of politics, the world of the international, is dangerous to any societies, since all societies are properly societies of intrinsic social relations. This particularity of social relations draws its theoretical basis in Saint-Just's anthropology, which holds that intraspecies behavior, the natural basis of societies, is different from interspecies behavior. Intraspecies behavior is parallel to the social relations within a particular society, which society may take on the modern form of the nation-state, and interspecies behavior is parallel to political relations, which may take the modern form of interstate relations in what is known as the international system. Both social and political relations transcend any particular historical societal forms to which they may be connected, and thus for example, social relations as the natural basis of law, morality, and justice, including the justice of fair or equal distribution of goods may be found in the tribe, in the city-state, or in the nation-state. Likewise, political relations occur between tribes, city-states, and nation-states. With regard to distribution of goods, different economic orders might be just within their own social realms, but might be unjust outside of these realms. The Fragments lists, under 'Institutions du commerce' the rule "Nul ne peut acquérir de terres, former de banques, ni entretenir de vaisseaux, en pays étrangers; ${ }^{206}$ the intraspecies relations that are the basis for society require indigenous social institutions, or rules and customs, for their establishment and perpetuation. Saint-Just's anthropology though, like that of Rousseau and Kant, retains the sense of the conjectural here partly in its lack of 
further elaboration of animal societies, even when animals are seen as akin to human beings for the purposes of political theorization.

The practical effect of the particular disposition of the political in Saint-Justian theory in a world in which the modern nation-state was largely the entity within which the social would now be circumscribed was not described by Saint-Just in his theory to any large extent, but it can be discerned from revolutionary exigency, and in this discernment is evidenced another instance in which the revolutionary situation provides much of the template for the understanding of a post-revolutionary society in practice. In the actual nation-state context of the world which formed the international context of France in Year II, Saint-Just took aim at England in particular, ${ }^{207}$ placing the onus for France's economic deprivation and degradation there, though not on England's own internal social relations or its people, but rather on the English government and its political maneuvers. Consistent with this separation, the danger to social right then comes not from the particular character of the social relations between the persons within foreign societies, whether these societies be tribes, city-states, or nation-states, but rather from the realm of their own exterior, which exterior is the domain of relations between peoples - in this case the relations between nation-states, or international relations. The government, which Saint-Just separates off from sovereignty, is particularly apt to confuse the political with the social, the will of the people with the desires of the government and of merchants and financiers:

Toutes les lois que vous ferez contre le commerce de l'Angleterre seront des lois dignes de la reconaissance du peuple anglais, également opprimé par la noblesse, par le ministère, et par les commerçants. Ceux qui ont prétendu ici que vos décrets nationnalisaient la guerre, ont-ils fait cette insulte à l'Angleterre que de n'y reconnaître comme nation que ses traitants et que son roi? ${ }^{208}$

In the particular context of the Rapport sur la loi contre les Anglais, Saint-Just is arguing 
against an extension of said law to other nations, since these nations' external politics may be either more or differently connected to their proper origins in the people of the respective societies, as they are formed as persons naturally by social relations. John Rawls's idea of The Law of Peoples ${ }^{209}$ is here comparable to Saint-Just's notions about the proper origin and aim of laws. In his description of The Law of Peoples, Rawls distinguishes between internal and external governments, and describes a "consultation hierarchy" which pertains to the description of societies with regard to the level and authenticity of the people's input in governmental decisions. Societies like that of England in Year II of the French Revolution might be classified in Rawls's scheme as "not well ordered". Such societies in Rawls's sketch of them are classified thusly when "their members are denied a meaningful role in making political decisions. ${ }^{210}$ Rawls tries to address the problem of cosmopolitanism with regard to the creation of shared values and meaning, and it is here where his theories form a valuable attempt to continue the application of ideas similar to those of Saint-Just through this problem, which is the problem of how societies form a natural social bond when there are always differences brought about by the fact that "Historical conquests and immigration have caused the intermingling of groups with different cultures and historical memories who now reside within the territory of most democratic governments." ${ }^{211}$ Rawls, like Saint-Just, leaves aside a deep speculation on what underlies the formation of social relations, Saint-Just resting with the observation of a natural intraspecies trust and lack of fear, and yet clearly adumbrating a theory of social relations which is not race theory or exclusive of those with foreign origins per se. In Rawls, this leaving aside is explained by an original need for common sympathies "no matter what their source may be"212; while Saint-Just's theory takes implicitly Robespierre's famous approach to this question of the origins of common sympathies ${ }^{213}$, which asks only whether or not one is free, and Saint-Just takes this for a natural precondition of the social, but offers limited explanation of what constitutes a species, 
though this ideas of species is part of the anthropology underlying the explanation the basis for social relations. Saint-Just seems to take up tacitly what Rawls takes up expressly in this area, and that is Rousseau's formulation that it is wise to "take men as they are and laws as they should be." 214

Saint Just, however, also makes a more penetrating economic critique of the "consultation hierarchy" than does Rawls. As noted elsewhere, ${ }^{215}$ Saint-Just does not yet make the economic critique separate from or preeminent in relation to a political critique, even though it is penetrating in its prescience with regard to later communist critiques of economic exploitation, capitalism, and consumerism. In the Rapport sur la loi contre les Anglais however, Saint-Just's focus on and prioritization of raw materials and his connecting of these to proper relations of the social indicates that the kind of society in practice which the revolution aims to bring about is one which is focused on the meeting of basic needs, and it also presages later critiques of consumer society which described false needs in the form of derivations from basic necessities of life: ${ }^{216}$

Ceux qui demandent la même loi prohibitive pour tous les étrangers, ignorentils que les autres n'avaient point la politique exclusive des Anglais? Tout leur commerce, au lieu d'être en prix de main d'cuvre, est en matière première: l'une fournit des cuirs, l'autre des métaux, l'autre des bois. $\hat{O}$ vous qui vous avez forcés de parler de la sorte, mettez enfin quelque différence entre vos ennemis, selon la différence des rapports et de nos intérêts! ${ }^{217}$

Here too, Saint-Just's idea of differentiation of enemies parallels Rawls's determinations of societies on the basis of their level of their liberality or their "decency,"218 and is similar to Rawls also in that Rawls places emphasis on the social, and even on social institutions within societies. $^{219}$

Saint-Just though moves in a more radical direction than Rawls in his social theory, one that is distrustful of the commerce of markets and their attendant ideologies, and 
presages the development of critiques on this basis, such as critiques of the exploitation of labor and of alienation. Following on his words quoted above, Saint-Just adds:

Il n'y a point d'indiscretion à parler ainsi: nous avons besoin de matières premières; on a besoin de nous les vendre. Nous n'avons donc proscrit que le riche bénéfice du commerce de l'Angleterre sur la main d'cuvre: ce commerce entretient l'industrie de nos ennemis: il donne aux fripons de l'intérieur le moyen de réaliser le fruit de leurs vols; il fournit au gouvernement ennemi le moyen de nous épier. ${ }^{220}$

The favoring of manual labor and of closeness to the earth, as it were, and of basic human needs is also found in the Fragments, the blueprint for practice, in such laws as " Tout propriétaire est tenu d'être laboureur jusqu'à 50 ans ou il paye double tribut. "22I Rawls, while critical of market economics, also bases his notion of liberal personhood and citizenship on it to a greater extent than does Saint-Just, ${ }^{222}$ who attempts to go further in pursuit of justice than minor accommodations accorded to the people in the face of exploitation, which exploitation has become increasingly an international phenomenon characterized in the contemporary world by the state apparatus's existence as a mere accommodation for such machinations of international capital as the credit insurance trade and the redesignation of state monies as "sovereign wealth funds", all of which distance the citizen and member of society from basic and more original needs. In the face of such and their power to determine "choice" and the personality based on such consumer notions, one might doubt first of all whether liberal theories of personhood, society, and justice are adequate to the task of creating justice in a society, and this doubt is partly due to the problem of the way in which international actors, systems, and phenomena are determinative of these very conceptions. ${ }^{223}$ Certainly Rawls, as an eminent exemplar of contemporary liberal theory, is sincerely concerned with at least some important aspects of economic injustice, as are other liberal theorists. ${ }^{224}$ Yet, the tradition from which Saint-Just wrote, a tradition that included such theorists as Mably and Morelly, his more 
central placement of a critique of economic abuses and derivations, and especially his involvement in a revolution which aimed to change social conditions and refused incrementalism and piecemeal reform, place him ultimately outside of the liberal tradition of political theory. It is in placing Saint-Just within a proto-communist lineage that one can understand the relevance of the concept of the closed society to Saint-Just's conception of justice and the identity of justice and uncorrupted social relations. The closed society is at base and its more contemporary sense, a society that has attempted to close itself off from market forces. Saint-Just's ideas of interiority and exteriority, or a social au-dedans and a political audehors are formed significantly by the grouping together of the crimes of the wealthy, of the international movements and activities and networks of the rich, which for Saint-Just form effectively an international criminal syndicate which operates to corrupt distributive justice, even as it disguises itself in traditional international diplomacy and rhetoric in which choice and self-interest are deceptive concepts:

Le droit des gens n'existait plus qu'entre les rois qui se servaient des hommes comme de chevaux de course; aussi se jouaient-ils des biens et de la vie des sujets, avec d'autant plus d'assurance, qu'ils savaient les enivrer de la coupe sacrée de l'intérêt. ${ }^{225}$

Saint-Just, while placing an economic critique of distributive justice into a theory of the political and of the social, also actualizes this form of justice via revolution.

Despite the importance of a pointed theoretical economic critique, it is perhaps in revolutionary action that we can more significantly distinguish Saint-Just from the liberal tradition. Revolutionary action as a category of action may have special value and be unique in its ability, in a context of presumed international democratic order, to actually move societies into line with political-theoretical ideas, something which ideas which emerge from a milieu of liberal political theory have not been able to do well. Even if Saint-Just and other 
members of the government of Revolutionary France are merely the followers and codifiers of the revolutionary actions of the lower classes, an effective dressing up and making respectable of sansculotte ideas, they put the letter of theory and the work of action to these latter ideas, such that, perforce, political theory is mixed with revolutionary action more significantly than when theory is purely anterior to, or distanced from its subject. Saint-Just's experience then as a bourgeois interpreter of the people's actions, also raises questions about the ability of theoria in its Greek understandings as distanced from political action ${ }^{226}$ to effect significant change with regard to justice, and about the relationship between liberalism and actualization. Revolutionary action as a mandate from the people is both a refusal of the incrementalist tendency of liberalism, which bias can easily become an anti-revolutionary bias and an apologetics of corruption, and an acknowledgement of the potential for material and historical conditions of life to create political philosophy, and even to create political philosophy's understanding of its own subject matter and character. With the French Revolution and with the political philosophy of Saint-Just, we have an example of how revolution quickly dissolves both the distance between theory and action and even reverses their common sequence, but also of how the ground for future political philosophy, its conceptual terrain and presuppositions even, are created by and have their origins in revolutionary action in the form of popular uprising. Saint-Just's attempt to create a theoretical justification for the Revolution and his creation of a theory of the concept of the social and a template for the social realm in practice are antecedents then to later reconfigurations of the terrain of $\theta \varepsilon \omega \rho i \alpha$, as evidenced by the development of material and economic emphases of Marxism and by the positing of democracy as the precondition of philosophy. ${ }^{227}$ If reforms in the liberal state repeatedly fall short of achieving social justice, especially distributive justice, revolutionary action may be seen as the most essential and relevant foundation for political-philosophical theory, and thus revolutionary action, as a particular type of action, might be seen as the future 
ground of a political philosophy which accepts democracy as its premise and precondition.

Expression of the Idea of the Civil Within the Area of Policy

The possessions of a citizen are the bases of the correctly formed and uncorrupted civil state (Civil 1 herein). These possessions, which Saint-Just thinks of primarily, though not entirely, in agrarian terms, ${ }^{228}$ cannot be taken away from the citizen, even by the sovereign. In the case of eminent domain seizures, the small landholder would be compensated adequately for the seizure of his or her possessions. ${ }^{229}$ Whatever one might make of the particulars or idiosyncrasies of the civil regulation such as this that Saint-Just had begun to set forth in the Fragments, one primary element of the civil state is the relative inviolability of the possessions of private individuals. While property, the foundation of the social state, is totally inviolable and not transferable, the Saint-Justian civil state as it is imagined in $D u$ Droit Social and in the Fragments also makes its own foundation, possession, rather secure.

Saint-Just accomplishes this combination of preservation of the private sphere and state induced fairness theoretically through his theory of possession as the foundation of the civil. The civil law protects and encourages relatively small scale husbandry by establishing a mandate for both the maximum portion of land that a citizen can possess ${ }^{230}$ and also a minimum of possession which cannot be violated ${ }^{231}$, though this latter amount is not specified. Responsibility is shared among citizens such that the Saint-Justian idea of independence also takes on a different character than it does in most liberal republican states. In the ideal civil realm, for example, creditors will be punished, says Saint-Just, if the debts accruing to the possessions of any citizen exceed the productive value of the land $\mathrm{d}^{232}$, and again, a maximum allotment of land is determined by the people, in consideration of what is 
best for all. Thus, in the Saint-Justian idea of possession, the liberal idea of private property is in some sense preserved, though most elements of potential force and inequality are removed therefrom by the state. From the vantage point of contemporary comparative politics, it seems that the ideal French society for Saint-Just is one in which the traditional property as possession is preserved, but that property is heavily controlled by the state, removing then the elements of force and exploitation that the liberal republican state and its supportive theories tend to see as unfortunate but inevitable. While Saint-Just describes the France he envisions as a republic, the civil realm's laws in the area of production and distribution seem closer to a certain modified communism when looked at in terms of distributive justice.

The corruption which brings about the degraded civil state (Civil 2) is often the result of finance. In Saint-Just's ideal, legitimate commerce has a legitimacy that is restricted in domain and origin, while finance tends to be seen as a corruption, with attitudes regarding it becoming relatively severe later in Saint-Just's sociopolitical trajectory, after the problems that were the result of finance and speculation multiplied. There is, however, even in the theorized civil state as it would exist in practice, an exchange of money. In theory, this is discussed as compensation in the form of le signe. In actuality, this signe became the assignat, and the actual practice of the economy of the assignat was one of much fraud and speculation. Commerce, though legitimate to a fair degree, is at the outset, in the theoretical ideal of the civil realm, described differently than it would be described in later normative usage, since the needs which underlie it are inherently different in a society based on social relations of affection. Thus, the domain of legitimate commerce in ideal practice is different from the corrupted commerce of improperly derived needs which was its only referent for 
those who could not discern a deviation from natural goodness and from this original commerce of legitimate needs such as nourishment and reproduction. The difference though, lies not only in the type of needs, but also in the degree, with greed being persistently pointed to as an effect of the political which must be guarded against in the civil realm, lest natural social relations be attenuated. The experience of this in action, against which and after which Saint-Just establishes a theoretical base for the civil, is the catalyst for the revolution:

"l'avidité de luxe tourmentait le commerce et mettait aux pieds des riches la foule des artisans. ${ }^{233}$ Whether with regard to quality or quantity, the extent to which deviation from the properly commercial occurs then is the extent to which needs are not derived from social relations and is also the extent to which this deviation occurs is in large measure the extent to which the ideal civil state becomes the corrupted civil state.

Civil relations are commercial relations in the realm of the civil in practice, the civil in its ideal actuality. The historical delegitimization of the actual civil realm and the legitimization of the corrupted civil realm has its origin in the idea of force. In the explication of the corrupt civil state in Du Droit Social ${ }^{234}$ Saint-Just gives a brilliant and prescient explanation of inequality and its origins, arguing that it is in the identification of things and men, or of a thing and a person which occurs in this state. Since things can have unequal value, persons, under the incorrectly derived civil law, have been considered to have unequal value as well, ${ }^{235}$ but Saint-Just's critique of the improperly derived civil goes further to indicate that significant ethical and political philosophies of the Western world, because they are derived from this confusion, are falsely derived. In Du Droit Social, Saint-Just implicates both the Mosaic law and the civil laws derived from contract theory:

De même que l'homme et la chose devaient être séparés, de même l'homme et la réligion devaient être indépendants. La loi civile mit l'homme, les choses, et la divinité dans l'état. La loi sociale portait l'homme à cherir son auteur, la loi civile le lui fit craindre. La conservation avait été le prétexte de l'état de force, 
la divinité fut un prétexte d'obéissance. ${ }^{236}$

The ideal civil state in practice then, can be considered an antecessor of later communist political philosophies because of Saint-Just's view of the nature of property and ownership in the ideal state. The ideal which Saint-Just describes is one of small allotments of land, accorded to those who work them, with no one owning too great a share of land, that is, land beyond that which he could himself work productively. This type of limited allotment is a result of the civil law being in proper relation to the social law ${ }^{237}$ Property in its specific content is only oneself and one's societal domain, and these types of property are both inseparably part of l'empire, that is, the territorial aspect of the social realm, that circle of intraspecies relations which shares a land and affections. ${ }^{238}$ This inseparability means that no one in a Saint-Justian civil society is an owner of real property in the same sense in which one owns private property in liberal societies. Such a shared notion of property, albeit with some element of the traditional individual in a liberal republic, carries inherently a predilection for the mutual satisfaction of needs; in other words, these needs and their satisfaction are inherently social in spirit, and in letter are tied to the social law of property in its dual nature, which satisfies both particular and communal ideas of the individual.

Saint-Just asserts that a morality that rests on precepts "isolates all" while a morality that is founded in the laws "inclines all toward wisdom" and establishes relations of justice between citizens. ${ }^{239}$ The civil law then must be based on the theory that is the social law, and this is property. This social law, which Saint-Just identifies with property, is based on social theory, 
which in Saint-Just one might say, struggles to be based on nature. And yet, just as Saint-Just appears to be following a traditional political-philosophical process of derivation of law and theory from nature, he immediately turns to the novel actuality of the Revolution as an origin or basis for theory. In doing so, he points up the inadequacy of Smithian and Montesquieuian political theory: "Smith et Montesquieu n'eurent jamais l'expérience de ce qui se passe chez nous. ${ }^{240}$ This ce qui se passe chez nous was a popular uprising, based only somewhat and indirectly on any political theory. Thus, for Saint-Just, popular mandates and socially developed ideas and relations might inform and even create a people's ethic as well as could a political-philosophical doctrine that has other origins. One might then ask what would have been, or what was the ethic of the popular radical left, those who actually rose up in the streets, and what its relationship is to that of Saint-Just, who might be seen by some as a bourgeois usurper of the people's will. ${ }^{241}$ Was the ethic on which civil life is based and on which in this case rested the practical ideas for the distribution of subsistences and other goods a different ethic for the 'proletariat' than it was for Saint-Just? This question speaks in part to the larger question of whether or not it is possible to transcend class in one's thinking.

It may at least be argued that Saint-Just's existence as a political thinker and actor receives its necessary condition, or its actuality, from the spark and fire that was the rising up of the lower classes. Likewise it would seem that the theoretical component of a 'progression' in Saint-Just from theory through practice to the actual finds its origin in philosophy's existence among the privileged. Is the tension and uncertainty present in the directionality aspects of Saint-Just's political life then merely a class phenomenon? If we can associate the lower classes with action without theory and the upper with theory, theory that requires the luxury of leisure time, which allows for the possibility of theory as an end in itself, then is the delimitation of an ideal practice the province of the emerging bourgeois and 
its witting or unwitting apologists? In the Speech on Subsistences, Saint-Just makes a statement that seems to cast accord to this notion: "nos subsistances ont disparu à mesure que nôtre liberté s'est ést étendue parce que nous ne sommes guère attachés qu'aux principes de la liberté et que nous avons négligé ceux du gouvernement. ${ }^{242}$ Here, Saint-Just accuses the more purely theoretical idea of liberty in its dual role as conceptual among pure theorists and slogan-like among pure actors, seeming to call for a mediation in practice by invoking the term 'government', which contains the notion of practicality within it. Saint-Just is dreaming of the purely theoretical but is too aware of the actual to go more freely over into it. There would be too great an irony, too great a preposterousness, in becoming too philosophical when discussing the exigent condition of starvation, for what is philosophy when one is starving?

In actual practice which was consistent with its thinking and that of Saint-Just ${ }^{243}$, and which was in turn based on historical-practical reasons, the National Convention desired to both establish the sanctity of private property, ${ }^{244}$ again, in small allotments, and also to repudiate and banish important vestiges of the feudal system, which were themselves private property. ${ }^{245}$ This drive by the Convention and the political belief behind it raise the question of the nature of Saint-Just's political role and work, and the concomitant question of whether or not the theory-action reversal is best seen as applicable to revolutionary politics. Is SaintJust properly considered as merely a spokesperson for the Revolution, albeit one who translated the historically informed practice of the Convention and of other Revolutionaries into the old political-philosophical modes of presentation? And, if this is the case, what would such a philosophy be? To call it propaganda merely circles back to the question of 
where propaganda comes from, and thus again to the question of the relationship of theory and political action. In the larger historical picture, if the Conventionnels were drawing their beliefs from thinkers such as Mably and Rousseau, did these Conventionnels represent a dialectical point in a historical progression of ideas? Certainly their actions were partly based on these thinkers' political philosophies and certainly their actions greatly influenced and inspired later political philosophies. This momentaneity in a historical chain of development is certainly one way in which Saint-Just has been seen by others and indeed saw himsel $f^{246}$ One can ask then, whether the political existence of Saint-Just is a dialectical moment. The current unanswerability of questions about sequence and direction and theory and practice in understanding politics is in fact the very ground on which a new theory of these relationships can be built.

In the more specific area of economic thought and goods distribution, this question is manifested at all levels, including within the political work of Saint-Just, and the uncertainty it involves, and which is the foundation of this line of questioning of theory and practice and their relationship and inherence as concepts pertains at and pervades all levels of analysis. The question of whether or not Saint-Just was merely a spokesperson for the nonphilosophical economically redistributive ideas of the Conventionnels is a part of and almost becomes the question, "What is political philosophy?" Can political philosophy find a significant and proper origin in the demands of a state of exigency, as that exigency is understood by the representatives of the people? To what extent did the Revolution and the civil society it aimed to bring about need political philosophy for its justification, both before and after the fact? 
Expression of the Idea of the Political Within the Area of Policy -

Goods Production and Distribution

“Ne pas admettre le partage des propriétés, mais le partage des fermages."247 Property, as consisting only of oneself and a part of the total land of the society, and cannot be alienated, but possession of land by particular members of society is allowed. While SaintJust does speak of manufacturers and elements of production other than those involved in the production of basic necessities, and even at one point says that France is not the proper place for a primarily pastoral society ${ }^{248}$, he continually endorses, in passages such as the one above, the primacy of agricultural production as the type of production which is mostly authentic in terms of needs. This authenticity is, in reality, determined by its distance from the political, by its distance from the forces of the political which Saint-Just saw as appearing threateningly the further one moved away from the commerce of agriculture, a commerce of basic needs, to commerce involving other goods. Even here, in the area of foodstuff production, Saint-Just wants further guarantors of the proximity of commerce to basic needs, which themselves are almost an appurtenance of social relations. Thus, the idea that the fermage, an area of land supporting tenant farming, would be partitioned in its possession, is a further level of guarantee against accumulation of possessions beyond a level that is consonant with affections for and unity with one's fellow citizens, which lack of affection and lack of unity come from the exterior.

And yet the political serves in some sense a purpose theoretically, since it is the explanation for corruption of human beings that is their historical movement away from social harmony: "l'homme au sein d'une petite société s'arma contre l'homme pour étendre son champ et qu'il fallut une loi politique pour comprimer cette violence intérieure. ${ }^{249}$ The political is then the force which keeps the practical realm from its realization, a negative 
force, and also a force for the promotion of the false consciousness ${ }^{250}$ of the corrupted civil realm, in which commercial interests have so far distanced themselves from real needs that even speculation and usury and other such exploitations are considered legitimate; it retains though, a value in its necessity as that which makes Saint-Justian theory cohere, and that which is necessary for the historical aspect of the legislator's arguments. The savage state created by the conflation of the relations of the au-dehors with those of the au-dedans also makes the legislator as founder a revolutionary in actuality. The future aspect of the legislator may henceforth need to adopt the mantle of revolution, insofar as revolution is fully cognized historically; Solon's pro-agrarian, pro-proletarian reform, to which Saint-Just refers and from which he draws inspiration, are not always called revolution, nor are the reforms of the Gracchi and of others to whom Saint-Just refers, and yet their character is revolutionary. ${ }^{251}$ The question of role and character of the legislator-philosopher with regard to the political distinction contains within it many questions, including that of whether the separation of the political from the social was already a developing historical precedent even in the ancient world, and, if so, in what way this distinction was cognized. This latter question then also inevitably brings up the question of class consciousness, or class in relation to cognition, and along with this question come questions about theory and action. If the will of unskilled, agrarian peasant toward, for example, a redistribution of land is taken up by his modern bourgeois or ancient aristocratic protectors or champions and made into a theory for the bringing about of a revolutionary restructuring of the political state, we have an instance of action's formation of social or political theory in the sense that the will of the illiterate peasantry requires an articulation by the educated to be translated into political change. In the context of historical development, 'the social' is an imputation to the ancient world from conceptual consciousness in the sense that the reforms enacted by aristocratic reformers such as Solon and the Gracchi intended to reconfigure the political establishment 
by drawing on their power and abilities from their position within it, thereby becoming the messenger and translator of the people's will. In this process, one can wonder what might get "lost" in translation. Saint-Just asserts that it is the people who dictate to the governors what is to be done: "Le gouvernement est révolutionnaire, mais les autorités ne le sont pas intrinsèquement; elles le sont, parce qu'elles exécutent les mesures révolutionnaires qui leur sont dictées. ${ }^{252}$ However, the role of the legislator-philosopher as founder of the social, is preserved in a discernment which is something other than the mere conveyance or translation of the people's will. "Que [le peuple] suive le conseil de Minos, ${ }^{, 253}$ exclaims Saint-Just. We might see in Saint-Just then the signs of the preservation of bourgeois conceptions of intermediacy with regard to the fight against forces inimical to the social, in the form of his retention of the idea of wise men who are well regarded by the political establishment, the separate social culture of which establishment forms its own separate consciousness within a context of political power. Insofar as the social has developed in contradistinction to political power, that is, in contradistinction to access to such trappings of power as education and the holding of offices in the state, the social becomes identified with revolution historically via the action-as-work activity of the workers in the form of rebelliousness, work stoppages, and lowered productivity levels, which forms of action are then translated and articulated by those who operate in the milieu of the political. ${ }^{254}$ In this sense we can say that Saint-Just's action goes a long way toward the reification and elevation of the social as the realm of action in a context that has not enjoyed political power historically, but that it itself perhaps retains elements of the political in the conception of the legislator-philosopher. Saint-Just's radicalism with regard to distributive equality though, portends a future in which the legislator-philosopher becomes more fully integrated with the social, which integration might be said to be already instantiated by Saint-Just's very existence as modern revolutionary, as one who then more fully realizes the possibility of revolutionary action as the corrective 
justice function of the legislator-philosopher that pseudoactual, or pseudomythical actions such as those of Minos or Solon leave as susceptible to categorization in the realm of pure historical theorizing, speculation, or myth-making. Even if we can question the imputation of categories and actions to past times, this does not invalidate the ability to see revolution as having a heritage of action against the political, for we can recognize a lineage of spirit and class consciousness, which, for our time, has cogency. Insofar as political philosophy continues to have value through its altered conception in the philosophy and action of SaintJust, we can ask further what its character will become. Will the future legislator of the practical and actual society of social relations, the new political philosopher, the warrior against the political, necessarily be called a revolutionary? 


\section{EXIGENCY}

The Actuality of Practice

\section{Revolution}

Exigency is a political condition which comes about as a result of perceived political problems, and then this condition itself can beget problems, thus creating, vis-à-vis a political idea base, a two-step removal from this idea base. One begins with an idea base and then encounters a problem in its realization. When this problem is of a certain nature, one enters into political exigency. There are a few categories of exigent problems under this description. One is the category of time-bound problems. In this category would be found political problems which are pressing and which have a limited time frame for their viability and value. A second category of problems which can bring about this exigent state of affairs is that of government stability. In the French Revolution, many policy decisions were made by Saint-Just and his colleagues on this basis. If a contravening policy or event or action will bring down the state, especially while it is still delicate and in the process of formation, it must be considered expedient to act immediately against it, even when more fundamental problems are present. The state cannot act on the more fundamental problems if it ceases to exist. A third category of problems which induce exigent political thinking and policymaking is denoted when either policies or actions that are contrary to what are considered the essentials of the state occur. As a member of the Committee of Public Safety, Saint-Just was bombarded with requests for action or treatment of a problem. An important criterion for the decision as to which problems to address was the determination of how much they were contrary to the essentials of the new state's ideals. These three categories of problems of 
exigency overlap and there are certain problems which involve all of them.

The term and category of exigency as it is employed here should neither be overly emphasized nor reified. That is, it should not be comprehended as a concept worthy of analysis per se, but rather should be seen only as an intermediate explanatory aid, necessary temporarily as the idea of revolution, informed by Saint-Just's sociopolitical existence, is developed. In the development of the idea of revolution as something that is not thought in the traditional sense and also not existing simply as action which does not have an important relationship to thought, that is, as something which is neither thought nor action, but is also both of these simultaneously, an understanding of revolution must at first reach back into analysis and traditional political and temporal explanation in order to be understood. As heuristic devices are provisional, exigency can be seen as a provisional historical moment and connection, which simultaneously obfuscates and elucidates, in the manner of all heuristics. In its forward looking, neologistic aspect, the heuristic is elucidative and moves toward accuracy of understanding, while in its retrospective and contemporary aspects it tends to obfuscate.

In other words, a synthetic philosophy emerging from revolution cannot be understood adequately with an anterior episteme. In the actualization of political ideas in a period of revolution there is the need to press the theory in mind to a marked degree, but also to take into consideration what the actual state of persons in society is, and to then examine the area of difference between the two. This difference constitutes the ground of the development of policy. The actual development involves communication of the ideas, and the revolutionary context of the communication of those ideas urges a rhetorical communication. The communicational aspect of actualization is its first aspect, the first step in the actualization of a social idea. Apparently, Saint-Just was working on Du Droit Social when he gave his 
Speech on the Constitution of Year I. In general, his speeches to the convention and his reports take on the task of communication of his ideas, and this communication shows a strong correspondence between the ideas expressed in the written works and those which are expressed in the speeches. This is particularly notable in the case of the Montagnard Constitution with reference to $\mathrm{Du}$ Droit Social.

In addition to an examination by the legislator of the current circumstances, action becomes important in the present: Les circonstances sont pressantes: on doit parler par résultats, ${ }^{255}$ while theory informed by this present that emerges out of a corrupted past becomes important for the future. It is clear in the Fragments that Saint-Just is attempting to speak to posterity about lessons learned in exigent circumstances, the circumstances of devastating attacks on the Revolution and its leaders. ${ }^{256}$ Saint-Just's earlier optimism then about implementation of political-philosophical ideals changes later to a view that is educated by actuality. This later view is then expressed in a tragipoetic way in the early sections of the Fragments. The earlier optimism which led him to state to the Convention and to the people, evidenced in quotes like the following:

L'Europe vous demandera la paix, le jour que vous aurez donné une constitution au peuple français. Le même jour, les divisions cesseront, les factions accablées ploieront sous le joug de la liberté; les citoyens retourneront à leurs ateliers, à leurs travaux; et la paix régnant dans la République, fera trembler les rois ${ }^{257}$

was educated by the actuality of the grand struggles of factionalism and the continued and growing sense of foreign contravention of the Revolution, that is, contravention from the political world, the world outside the circle:

Tous les hommes que j'ai cités plus haut [Scipio, the brothers Gracchi, Algernon Sidney, Jan van Olden Barneveldt, Benjamin Franklin, Joseph Chalier, Jean-Paul Marat] avaient eu le malheur de naître dans des pays sans institutions, en vain ils se sont étayés de toutes les forces de l'héroisme; les factions triomphantes un seul jour les 
ont jetés dans la nuit éternelle malgré des années de vertus......... ${ }^{258}$

and, “......L'étranger, de vicissitudes en vicissitudes, nous avait conduit à ces extremités."

A famous line of Saint-Just, which became the title of Albert Ollivier's book, is one testament to the fact that Saint-Just did not anticipate the resistances to the Revolution that comprise what is here called 'exigency': "En effet, la force des choses nous conduit à des résultats auxquels nous n'avions point pensé. ${ }^{260}$ It is again the political life of Saint-Just that presents itself to us for patterns for knowledge in political science, and not always his own intention, and yet, this line is famous perhaps in part because it is indicative of something like an awareness of the limitations of intention, and also of a simplistic notion of theory's translation into action. Revolution is exigency, an unportended state of affairs, in its actual working out.

If exigency is a proper categorization that can be distinguished from theory and practice and a proper category for that political actuality of opposition and conspiracy that met Saint-Just's attempts to establish a revolutionary society, there is a parallel between the civil state and the state of exigency. We have already seen above how the civil has two manifestations in the theory of Saint-Just, a corrupted manifestation, and a correct manifestation out of the natural. The exigent circumstances of revolution and its opposition were then the result of the conflict between these two civil states, the conflict between the one which was already actualized and the one which was being born in the institutions of Saint-Just. The laws that would establish these institutions were the manifestation of "le droit social". Thus, law is based in right, and it is practice in the fully actualized revolutionary state. The contingencies of the state of exigency forced the law back into the category of right unmanifested. Thus, practice becomes right again since its incipient laws 
are held in check by the exigencies of revolutionary foundation. In Saint-Just's eyes, we can say that the category of exigency as revolution is produced by the forces against it, and for Saint-Just this would mean the forces of force itself, which he and other revolutionaries in a lineage of radicalism have named counterrevolution.

Since this work attempts to understand Saint-Just as he understood himself, and also stands in the service of the congealment of the idea of revolution, the concept of counterrevolution itself is important. In an attempt to carve out a content for revolution conceptually, Mark Hagopian identifies three significant determinants of counterrevolutionary movements: regionalism, religion, and foreign intervention, ${ }^{261}$ and describes these determinants in the French Revolution. A good amount of Saint-Just's work was really negative, in that it was work geared toward extirpation of enemies of the Revolution.

Hagopian's description of regionalism describes accurately part of the counterrevolution in France, particularly in the case of the uprising of the Vendée. The argument made by Hagopian is that rural areas and economically backward areas are more likely to be counterrevolutionary. The interesting contrast in this first determinant of counterrevolution with the work of Saint-Just is that Saint-Just imagines an agrarian spartan idyll as the Revolution's aim, and yet the history of revolution and counterrevolution shows that counterrevolution is most likely to develop in rural agrarian areas. Although Saint-Just was a political actor and theorist, he certainly did not adopt the more contemporary guise of political scientist. However, he did rely on reports of economists and also looked to the theoretical-observational economics of such writers as Mably and Montesquieu. Ultimately though, Saint-Just's work against counterrevolution was rooted in political philosophical ideals more so than in economics, and lacked to some extent the middle ground of an 
economically elaborated theory of practice. ${ }^{262}$ This leaves his development of specific economic policy mostly, though not wholly, in the realm of exigent, revolutionary practice. The rurality of most counterrevolutionary uprisings though, is a testament to the value of the combination of a focus on agrarian production and an emphasis on unity that was manifested in the advocacy of a non-federal structure of governmental organization.

With regard to Hagopian's second broad determinant of counterrevolution, religion, Saint-Just laid forth in his Fragments many institutions which are quasi-religious or religious, depending on one's understanding of and definition of religion. Thus, in this area, the civil practice of the future state established by the Revolution is more precisely laid forth, and yet the case of the Cult of the Supreme Being stands out as perhaps the most significant 'religious' endeavor of the Revolution, even as Saint-Just's theoretical practice did not have time to adequately address it, leaving its development in the realm of the emergent. This foregoing is the positive or revolutionary element of religion in the experience of Saint-Just's political work.

The negative work against established religion has a foundation in Saint-Just's theoretical work, but no real component in the area of theoretical practice, since the positive institutions laid forth would be the guarantee that counterrevolutionary religious groups and persons would not be able to tarnish the state, if they could exist at all. But the guarantees against religion were not only found in the area of positive or negative work with regard to religion specifically, but rather also very much in the economic and status connections of religious power. Although Saint-Just places a negative importance on force, he also critiques the particular religions of France at the time, Christianity and Judaism, by impugning the Mosaic law due to its use of fear. Though this use of fear could be successful as were the counterrevolutionaries, it was a corrupt success, and the thought of the revolution for Saint- 
Just is that humankind can do better than dishonesty in the form of historical fictions as a basis for society, even if such fictions can succeed in a corrupt way: Moïse fut le plus profond et le plus habile de tous les hommes en même temps qu'il fut le plus méchant. ${ }^{263}$

The third of Hagopian's counterrevolutionary determinants, foreign intervention, is the one which is most clearly attacked by Saint-Just at all the points of his work, in theory, in theoretical practice, and in the Revolution. Although Hagopian states that

Foreign help of various sorts was forthcoming to counterrevolutionary émigrés and agents in the French Revolution; but a balance sheet of this often clumsy, inadequate, ill-timed intervention would probably show that it helped as much as it harmed the cause of the revolution, ${ }^{264}$

the best argument for the importance and correctness of Saint-Just's relatively larger focus on this element of counterrevolution is the resignation of most of the Comittee of Public Safety and of most of the Committee of General Security within six weeks of Saint-Just's death, after their recognition of the rectitude of Robespierre's warnings about foreign enemies.

The wisdom of Saint-Just's revolutionary strategy's focus on foreign intervention is then demonstrated by subsequent events, such as the cooptation of the Revolution by Napoleon and the Restoration, and this demonstration provides an affirmation of the correctness and consistency of first, the theoretical establishment of the au-dedans and the au-dehors, second, the practical guarantee of the removal of the political, which is identified with the foreign, through social institutions, and third, the revolutionary ardor with which foreign enemies were pursued in the period of the exigent circumstances of revolutionary correction.

If we glance backward from the questions having to do with the implementation of ideals that see themselves as progressive to the origin of such ideals, we see that political philosophy in its traditional character, when considered as fundament for the development of 
ideals, does not necessarily favor or point to revolution as their mode of realization, or even to any plan or mode of realization. If we add though, the criterion of radicality to the criterion of progressiveness to carve out a newer and more specific content for the revolutionary, then radical action, as correspondent thereto, becomes the corollary of radical thought, and revolution acquires the character of radicalism in its active component as well as in its aspect as pure thought or speculative ideation. In this way revolution is distinguishable from reform. Even if radical thought sometimes overlaps the category of liberal-conservative thought, since radical ideas appear there, revolution makes clear its distinction from reform by the correspondence of radical action to radical ideas. Reformism, even in its consideration of radical ideas, considers the goal in mind within a framework of incrementalist assumptions about procedure and possibility, and reform trusts in the system already in place for the achievement of such goals as justice and freedom. Revolution, on the other hand, in its foundation in radical ideas, pitches its demands high, and thereby changes expectations and brings demands formerly considered unreasonable or excessive into a discourse of reasonableness and reasonable expectation. Insofar as thought is a network of discourses with conceptual nodes, revolution changes this terrain of thought via its audacity.

\section{Saint-Just as Revolutionary}

Suppression of the Ancien Régime -

Expression of the Idea of the Natural Within the Area of Policy

Ancien régime is a general term that is often used to distinguish what came before the 
French Revolution in terms of government and society from what came with the Revolution and after it. However, since revolutionary consciousness is something that unfolds over time, there is overlap between some elements of what is called the ancien régime and the Revolutionary philosophy and that of post-Revolutionary governments. Saint-Just's idea of nature as it played itself out in the aspect of revolutionary exigency which was its attempt to transcend the old world, was an incorporation of some of the very ideas of that world, and it is with regard to nature that Saint-Just's theory is most reformist and most bourgeois. In the former regard, Saint-Just's attempt to hold onto nature as a value and as an a priori, or origin, connects it to past reforms which, in terms of the idea of developing historical consciousness, were less conscious than purely revolutionary actions, reforms such as the so-called Ordnance de Villers-Cotterêts, which had the typical results of reform, piecemeal gains for the protoproletariat which were mixed in their value. ${ }^{265}$ In the latter regard, the pseudomythical idea of the species as it connects to politics allows for bourgeois philosophers to idealize patriotism, nationalism, and the idea of a people, as opposed to theorizing universal conditions and material-historical conditions which precede and transcend ideas of political groupings.

Natural social relations did, for Saint-Just, not involve dishonesty among persons, since such was inimical to friendship and unity. In addition to fundamental and radical changes which reformists are too logically inconsistent and fearful to undertake, another way to describe the distinction between revolution and reform is in the purity that revolution demands. This purity is also revolutionary morality, and takes the form of a correspondence between theory and action. Thus, though the counterrevolution valued and shared some of the ideas of Saint-Just, such as the idea of nature, Saint-Just's inclusion of nature as a foundation is an ingenuous attempt to achieve pure goodness in the eyes of a class 
consciousness that was at a particular historical stage, just as the separation of divine right from natural right represented a somewhat earlier use of the concept of nature, and one which the ancien régime had incorporated into its reforms. The problem of the counterrevolution with regard to nature then can be described as twofold, as one of theory and one of action. At the theoretical level the counterrevolution, even in its aspect as a reformed and reforming ancien régime, was not radical enough in its accession to the idea of nature; on the level of the actual, the action required which is necessary to make theory moral was lacking. This latter lack of correspondence was then the dishonesty, or impurity of the ancien régime. Nature emerges emerged in Saint-Just's revolutionary consciousness as a prerequisite imperative such that its derivation, the harmonious society of social relations, is built on a friendship that will not suffer lack of integrity as dishonesty: "...l'aristocracie ment à son propre cœur..." 266

One of the hallmarks of both natural friendship and of revolutionary action in SaintJust is the belief in honesty then, honesty partly understood as both purity of thought and as correspondence between this thought and action. Purity of thought is in part also logical consistency, with reference to an ideal such as nature or the social. While attacks on the Revolution, resistance to which became part of the Revolution's raison d'être, could be said to come from a context of political thought which had already incorporated a valuation of the natural, Saint-Just's prescience with regard to the transcendence of the idea of the natural by the idea of the social did not find its homologue in the resistance to the revolution. Thus, the aspect of the counterrevolution which was its lack of radicalism with regard to nature was only one part of an embodied resistance to the Revolution, which forced practice into exigency. Another element lay in Saint-Just's distancing himself from even the idea of nature by moving on into its derivation as the social. With regard to the expression of the social, 
even if the elements of the ancien régime which he saw as contraverting the Revolution had been more radical with regard to nature, would they have taken the step toward the social that Saint-Just took? That is, would they have been able to reify a political base? The question is really a question of one's consciousness, and returns the question here to the import of the legislator-philosopher, the cognizer of the emergence of a concept's historical immanence, whether that emergence be an emergence from a teleological movement, or its emergence from material circumstances which only retrospectively, through narrative, acquire an aspect of the teleological. Was the counterrevolution then, as the misunderstanding of the political and the agent of its misplacement, which misplacement is an act against nature in the philosophy of Saint-Just, partly a failure of consciousness? Such a lack of consciousness could produce the double-dealing personality and dissimulation that was so frequently pointed to by Saint-Just and the other Revolutionaries as the source of the impediments to the Revolution's mandate in the natural. One could not serve two positions, or equivocate, and have integrity. Those who did so were, on the theoretical level, not sufficiently conscious with regard to, for example, the natural. On the level of practice perverted into exigency, that is, on the level of revolutionary action, such equivocation was a lack of integrity and this was seen as dishonest. Revolutionary practice, and Saint-Just himself, were subtle in their recognition of this:

Vous vous souvenez, citoyens, que les bustes de Necker et de d'Orléans furent portés en triomphe; vous vous souvenez des prétendues divisions concertées entre Necker et Mirabeau; vous vous rappelez la famine extrême de la fin de 1789. Ce furent les premiers moyens par lesquels on tenta de ravir au peuple la liberté et d'absorber la Révolution dans un changement de dynastie. Necker trempait secrètement dans la faction d'Orléans: c'était pour elle qu'il avait imaginé la double représentation de ce qu'on appelait alors le dernier ordre, et Necker ne défendit le tyran, il y a quinze mois, que dans le dessein d'empêcher que le trône, que briguait d'Orléans, ne fût brisé sans espérance. ${ }^{267}$ 
Expression of the Idea of the Social Within the Area of Policy -

Suppression of the Ancien Régime

There is repeated evidence that Saint-Just attempted, even while seeing the Revolution as a temporary state of correction, to push through his ideal of state and societal structure as early as possible, thus forestalling exigency, as it were, and moving immediately from the ancien régime to the republic. One instance of this is his argument before the Convention with regard to the administrative and representational organization of France in a speech given on May 15th, 1792, in which he argued for the ultimate division of France into small communes consisting of between 80 and 300 persons. ${ }^{268}$ This argument, which had as one of its motives to establish a direct democracy, did not win the day and instead it was voted to keep an intermediary level of authority as the lowest level of authority, an arrangement that was less different from the existing order than the plan of Saint-Just but which would also be less likely to guarantee that the natural social relations of the people were immediately translated into determination of the polity. Saint-Just's project here was consistent with his idea that the magistrates were to be considered beneath the citizenry. The argument also spoke to the dangers of federation, and called for the elimination of the départements. Arguments against federalism had already appeared in L'Esprit: "Ceux qui donnèrent l'idée d'une fédération, avaient trouvé le dernier moyen de changer la face des choses et de confondre la liberté: on l'attaqua de ses propres armes". ${ }^{269}$

The social is threatened from without, and it is necessary to fight the fight against the political before perhaps one can even understand what the social is, and its particular content remains somewhat vague insofar as it is based on feelings of affection, which are difficult to articulate. Thus, the theoretical assertion of the social comes after and during the revolution through the pen and actions of Saint-Just, even if Rousseau went a long way toward 
establishing the possibility of a discourse of the social in his idea of the general will society. The ethereality of the social even as it is the mandate of the revolution for Saint-Just is paradoxically furthered in some sense by attempts at clarification, many of which are negative. For example, we learn that the social does not consist or abide in the territory or land of the people - the social bond is somewhere else: "Si la division est attachée au territoire, le peuple est divisé. ${ }^{1270}$ The fight against federalism then is the fight against the mistaken idea of the social which, while possibly well-intentioned, is doomed in its corrupt origins, and can only pose as a state of social relations, a state founded on social right, until such time that its corrupted nature erupts forth to show its political origins. In the United States, "un jour un État s'arma contre l'autre, on verra se diviser les représentants, et l'Amerique finira par la conféderation de la Gréce." ${ }^{271}$ A federation is not a society of social relations, plain and simple. "[Les États-Unis] n'est point en effet une République." ${ }^{272}$ In the realm of exigency then, the implication is clear: the American Revolution was not a real revolution.

Expression of the Idea of the Civil Within the Area of Policy -

Suppression of the Ancien Régime

The civil is defined by Saint-Just as the relations between needs, but not all needs are social needs. As the presage of the idea of false consciousness is found in Saint-Just's imputation of falsity to the mélange of the relations of the political and the relations of the social which forms the corrupt civil, the related Marxist idea of fetishization, ${ }^{273}$ or false needs, 
is also present and relevant to the problems of the civil realm; in fact Saint-Just mentions the idea more or less specifically ${ }^{274}$ in writing that antedates Marx by fifty years. Money in excess of value of land, which land is a temporary possession of persons within the civil state that is ultimately within the permanent property of the territory of the social unit is an example of a false need and, in the new republic, Saint-Just aims to very strictly control lending so as to minimize or negate surplus value in relation to land ${ }^{275}$ This surplus value which lenders were acquiring was the false need of excess money, since the civil state is a commerce of needs that are genuine with reference to the social. Saint-Just establishes, through the experience of political opposition, a theory of surplus value that is not based on labor, but rather remains at the bourgeois level of ownership; however, this ownership is strictly controlled, to the point of being radically egalitarian, with lenders punished if they lend more to anyone than the value of the "fruits de champ" of the possessor.

The egalitarian ideas of Saint-Just with regard to the traffic of needs in the civil realm, though responsive to ideas from prior political thought such as the idea of independence existing in the mutuality of dependence that was present in Morelly, ${ }^{276}$ seem to draw their fire and substance largely from what is here deemed revolutionary experience. That revolutionary experience can be said to exist, in relation to the political theory of Saint-Just, as exigent circumstance. This exigency was repeatedly seen by Saint-Just and the other Revolutionaries as counterrevolutionary, but in contrast to Robespierre, whose political thought is largely contained entirely within exigency, and whose speeches have the tenor of invective without express connection to theory, Saint-Just is a theoretician of the Revolution par excellence, ${ }^{277}$ in that he constantly draws connections to specific political-philosophical ideas as referents, such as his idea of the exteriority of the political. In relation then to the traffic in genuine needs which is the proper civil realm, theory seems especially responsive to 
actual political experience, and specifically to experience during the Revolution. ${ }^{278}$

Theorization of the civil presents another important presage which brings Saint-Justian theory into line with later communist thought, and this presage is that of the idea of alienation, which emerges from Saint-Just's idea of xenogenic isolation. In the passage referred to above and elsewhere, Saint-Just contends that, out of the greed which exists in the corrupted civil state, which greed and corrupted civil state could only be a product of false consciousness, or consciousness derived from the misplacement of the political, emerges the isolation of each member of society. The isolation emerges in many ways, including as the result of the hoarding, hoarding that was the result in actual circumstance and in theory, of the greed that was allowed by the misplacement of the political and the development of false needs that include excess value:

Chacun voulut mettre à l'abri ce qu'il possédait; cette défiance et cette avarice ayant détruit tous les rapports civils, il n'exista plus un moment de société, on ne vit plus de monnaie.....L'avarice et la défiance, qui avaient produit cet isolement de chacun, rapprochèrent ensuite tout le monde par une bizarrerie de l'esprit humain. ${ }^{279}$

All such false needs of the corrupted civil realm were the result of the long, slow corruption of the social, which was the heritage of the ancien régime. When the direction of the relationship between theory and action was reversed, as it were, creating a dialectical interplay, the ancien régime as the opposition to the Revolution served one of the only functions of the political that was in some sense legitimate, and that was its function of creating the circle of the social realm by contrast and contradistinction. Thus, revolutionary exigency as progenitor of social theory in some sense required the opposition of the ancien régime, in its role as the actual historical repository of a misplaced political - as the regime of corrupt relations. Placing opposition and obstacle to the Revolution under its rubric is thus the recognition that the idea of the civil realm and its basis in genuine needs which never 
transgress social amity has actual reality only in its potentiality, which potentiality itself requires revolution for its realization, which revolution in turn can serve as a source of political theory, particularly political theory which involves the concept of consciousness or places importance on it. Revolutionary action for Saint-Just can then be said to take on the role of historical negation, and here a Hegelian-Marxian dialectic finds its proper placement in the historical.

Expression of the Idea of the Political Within the Area of Policy -

Suppression of the Ancien Régime

In a revolutionary stage of a political history, how could Saint-Just maintain a stance against force, the hallmark of a political which must be purged to the au-dehors, while still maintaining order? Is there order without force? To examine these questions, one can look to the idea of political power, which can be understood as the potential for force. ${ }^{280}$ If we understand political power as the potential for force, then the concept of authority can be understood as the possession of this potential or, more importantly, if we consider the psychology of power ${ }^{281}$ as both the progenitor and guarantor of the concept and its actuality, authority is itself a part of this psychology of power.

Removal of force from the social order is a fundamental goal of Saint-Just, and this goal can be viewed, in the Revolution, as always in mind. How does one maintain an aim, order, and unity in the absence of force? This important question is raised by the sociopolitical totality of Saint-Just's life, work, and action. We can find in Saint-Just's words and actions an integrity even under revolutionary circumstances, an integrity which attempts 
to steer the civil back toward the purely social. In Saint-Just's work one sees the attempt to exclude force from the social realm, the realm which usurps the political first via revolution and then via the social institutions which that revolution establishes, in the focus on banishment and treason, and in the linking of counterrevolutionary actions to the exterior, to the foreign, to the au-dehors.

It is also in this exclusion of force from the social that one can find a logical foundation for the patriotism of Saint-Just and the other Revolutionaries. In his Rapport sur les 32 membres de la Convention, ${ }^{282}$ the emphasis, both in word and deed (outcome), is on the bringing to justice of those who have fled. The crossing of the line between the social and the political, between the au-dedans and the au-dehors is the crossing of the lines of demarcation around the idea of force. This boundary is crossed in both directions, and both psychologically, as in the case of those who might attempt to propose laws that improperly place the political in the realm of the social, and more literally, as in the case of deportations across the border and the capture and bringing to justice of those who have fled or are fleeing the reestablishment of natural, apolitical social relations in France, that is, those who are fleeing the exigent circumstances of correction called Revolutionary justice. Misplacement of the social into the political domain, as it were, also occurs, and must be rectified:

\section{La Convention nationale rappelle dans son sein Bertrand, membre de la commission des Douze, qui s'opposa courageusement à ses violences; elle rappelle dans son sein les autres détenus plutôt trompés que coupables. ${ }^{283}$}

If we look into force itself specifically with regard to its presumed inherence in politics, we are led to ask how a government in practice can eschew force, and further how force can be eliminated as an imperative. In the work of Saint-Just, this takes place when the social realm properly reasserts itself over the political, with this crossing of lines of demarcation between the two, but what, more specifically, does the elimination and the keeping out of 
force look like in practice, and what does it look like in the exigent circumstances of revolution? In the Rapport sur les 32 membres de la Convention, Saint-Just's words provide an answer to the latter question. Here, Saint-Just's attack on the accusations of anarchy made by conspirators against the Revolution ${ }^{284}$ is evidence that the removal of force from the social realm is not the same thing as the removal of order, and yet in the Revolutionary period the enemies of the Revolution will take advantage of presumed or actual disorder, alarming the populace. By taking advantage of the exigent circumstance, revolution, counterrevolutionaries will use the advantage of the old foundations of order, authority and force, promoting the notion that order and security can only be produced thereby: ...si l'anarchie était la véritable cause de ces armaments, ils auraient cessé depuis la Constitution, ils auraient attendu avec respect l'expression de la volonté du souverain, ${ }^{285}$ qui ne peut pas errer. C'est un crime de prendre les armes lorsque le peuple est assemblée....les principaux auteurs d'un dessein si funeste se sont enfin désignés eux-mêmes en prenant la fuite. ${ }^{286}$

The existence of the relations of force in the elements of the counterrevolution which identified with the ancien régime created a moral imperative of action for the political philosopher in Saint-Just:

Les philosophes ont trop légèrement pris leur parti sur les désordres des affaires humaines, Sénèque et Montaigne et tant d'autres démontrent avec beaucoup d'esprit que tout va mal, mais le remède? Je n'aime pas les médecins qui parlent, j'aime ceux qui guérissent. ${ }^{287}$

The coincidence of revolution and philosophy in the case of the French Revolution was for Saint-Just the quintessential action of the political philosopher as one who both discerns when corrections to the social order are needed, and one also one who corrects, orders, reorders. The concern for order among partisans of the ancien régime, when it could be said to have understandable or ingenuous origins, was then with a superficial order, an order which was an alignment to a social realm that was merely an outgrowth of needs of the rich, 
of businessmen, of speculators, legitimized by intriguists and pretenders. Saint-Just's concern was with a larger disorder, that of the social itself historically, with the social considered philosophically. Political philosophers traditionally think and theorize about morality; in Saint-Just though, we can find, in addition to such theorizing, both a directive that the political philosopher be moral and an example of what constitutes morality in the political philosopher himself or herself. The content of morality is then, in one part, correct discernment of historical disorder, at which the political philosopher may fail:

"Montesquieu, si près de la verité, ne la point sentait lui-même," this disorder, in the case of Saint-Just and the French Revolution, a negation or rejection of the political, and the moral content of the prototype of the political philosopher as it unfolds in Saint-Just is then necessarily requisite of action. Insofar as an action arising in this way on the part of a political philosopher is moral, and insofar as revolution is a sure and rapid concretization of the duty of the philosopher to correct, to "heal", then one might say that revolutionary action is more moral than other types of "political" actions.

Institutional Establishment, Foundation, and Maintenance -

Expression of the Idea of the Natural Within the Area of Policy

Natural friendship was for Saint-Just not merely a part of an idyll. His emphasis on it in theory is correspondent to its obvious value in revolutionary circumstances of suspicion. In friendship ${ }^{289}$ and natural affection is found the certainty and security in the correspondence between idea and action, between affection and the consequences of affection. The very 
concept of the institution has, with regard to natural affections and friendship, a lineage of importance from theory through practice to revolution. In its theoretical mode, mutual affection is natural among human beings of the same species, or of the same circle. Its practical mode is Spartan and consists in institutions of affection and friendship, or civil society, and these are set forth in the Fragments. ${ }^{290}$ Its exigent mode, the mode of revolutionary circumstance, is as a strong defense against and refuge from the counterrevolution, which is a crime against nature. The counterrevolution as the force of the political injected into the social is then partly the result of the lack of social institutions which create and sustain natural affections. This lack allowed the confusion of natural relations which occurred with the mixing of the social with the political:

Les mours sont les rapports que la nature avait mis entre les hommes; ils comprennent la piété filiale, l'amour et l'amitié. Les mours dans la société sont encore ces mêmes, mais dénaturés. La piété filiale est la crainte; l'amour, la galanterie; l'amitié, la familiarité. ${ }^{291}$

The social institutions which Saint-Just was attempting to establish were the fundament of the state or society as it would exist in practice and yet, this society did not yet exist; the Revolution was bringing it about. The counterrevolution as the force of the political unleashed in the circle of the au-dedans though antedated the actual breakout of the Revolution. In the theory of Saint-Just, the counterrevolution consisted in historical developments like the creation of religious law, which was not natural. Moses was no legislator, and in fact his creation of laws was an act against nature. ${ }^{292}$ The operation of society in a corrupted practical mode perverts the function of the law in relation to nature such that a treason against nature, as it were, is legitimized. Saint-Just writes that the liberty of a flawed people (a people who has strayed from nature internally) "est une perfidie qui n'attaquant plus le droit de tous ou la souveraineté morte, attaque la nature qu'elle 
représente. ${ }^{, 293}$ The mode of revolution then is necessary to set up a more fundamental natural guarantee of social harmony, one that will not merely seem to promote natural harmony and fail to eradicate corruption, which is what takes place in the actual corrupted civil state: "Remarquez que lorsqu'un peuple emploie la force civile, on ne punit que les crimes maladroits, et la corde ne sert qu'à raffiner les fripons. "294

Saint-Just's ideas here are prescient in relation to later critical and revolutionary philosophy, and especially to Herbert Marcuse's idea of repressive sublimation. ${ }^{295}$ Analogous to Saint-Just's idea that a civil society that is itself a product of corruption could never properly punish crimes, rectify injustices, or fix flaws, which idea is revolutionary in its inherent opposition to reformism, is Marcuse's idea that the sexual, largely via technological apparatuses of control and repression, redirect the libido into repressive modes. To "raffiner les fripons" only further entrenches both corruption and deception, and thus the counterrevolution which again, in its essence as a product of convention as against nature antedated the French Revolution but continued in ardor during it, is the active yet sometimes unwitting taking up the ideas of the political while failing to understand that social harmony is a natural phenomenon, while political relations in the social relam are not. The analogy to Marcuse is really, more broadly, the presentiment in Saint-Just of the later Marxist idea of false consciousness. The counterrevolution then is a corollary to the political in that the political only properly exists functionally as that against which and in response to which the social is established, just as the counterrevolution establishes the condition of and mandate for revolution, which is corruption. Saint-Just holds tenaciously to the natural and yet also at times evidences elements of future historical development of the idea of false consciousness, albeit a false consciousness that is referential to the criterion of the natural. This reference to nature is generally what distinguishes earlier philosophies of the social from those that came 
later. However, technology's role in repression and sublimation in Marcuse's much later philosophy can be seen as a vestige of nature in a dialectical unfolding of in the sense that the idea of technology in Marcuse relies on the possibility of distancing human beings from something real, from that which is not fetishized and from that which is not falsely cognized by false consciousness. To put it anachronistically then, but in relation to later revolutionary philosophies, institutions can serve to ensure against the development of false consciousness, which false consciousness can be identified with the counterrevolution.

Exigency then is the set of circumstances that the counterrevolution, understood historically and broadly, brings to bear against the creation or recreation of the natural social realm and its harmonious relations. A society run under the auspices of social institutions which maintain natural affections and friendship, could never traffic in deception, since deceptive relations, including the self-deceptions of false consciousness, are not relations of friendship. For Saint-Just, the practices of the counterrevolutionaries were the practices of those denatured, and friendship's prerequisite honesty would disallow such practice, which in fact was the actual order of the day in the Revolution. The lack of awareness of denaturation and of the social caused a disbelief therein and a resultant cynicism, and this cynicism led to preposterous and mocking frauds, such as the false minutes of the Committee of Public Safety ${ }^{296}$ and a fabricated report disingenuously attributed to Saint-Just by Emmanuel Henri Louis Alexandre de Launay. ${ }^{297}$ These attempts were made in order to make the Revolutionaries seem frightening and dangerous, and thus to instill interspecies behavior in the social, or the realm of intraspecies relations, which beings in a natural state have no fear of one another and exist in a natural and original amity. 
Expression of the Idea of the Social Within the Area of Policy

- Institutional Foundation, Organization, and Maintenance

Instantiation of Saint-Just's idea that religious law is not social law and is not natural is found in some of the particular situations in which it was relevant to the counterrevolution. One such instance is the contestations between Catholics, Protestants, and Jews in 1790, which in effect were the result of an allegiance to religious law rather than to the social law, and which were seen as potentially undermining the Revolution. ${ }^{298}$ Such factionalism, which was to occur pointedly later within the revolutionary government, not only is against the social law of unity, but is made possible because the creation of this social law by institutions has not yet occurred. Exigency involves urgency, and the necessity of quickly setting up the mechanisms by which the social is both created and maintained, that is, social institutions. Put in terms of traditional political discourse, the fusing of the prince with the sovereign is the function of social institutions, and a primary function of revolution is to create the conditions under which the legislator can establish a new order:

Comme tout le monde délibère sans cesse dans un État libre, et sur les personnes et sur les choses, et que l'opinion publique y est frappée de beaucoup de vicissitudes et remuée par les caprices et les passions diverses, les Législateurs doivent faire en sorte que la question du bien général soit toujours clairement posée, afin que tout le monde délibérant, pense, agisse, et parle dans le sens et dans le cercle de l'ordre établi. ${ }^{299}$

Institutions for Saint-Just are in large measure customs and rules which are consistent with social harmony. In the Fragments, many of these institutions as they are set forth include the punishment of banishment from the au-dedans. ${ }^{300}$ The phrase "est banni" and others like it in the Fragments correlate severity with urgency, since during revolutionary 
exigency the legislator in his or her guise as revolutionary must not only rectify, via the promulgation of institutions, the existing displacement of political relations, but must also fight against new usurpations. Thus, even as institutions are being formed which will be the essential framework of the social, severity must be exercised to prevent their being stillborn. The severity of reprimand and punishment expressed in the Fragments as the most revolutionary of Saint-Just's works in the sense of its being the one most owing to emergency conditions and the most wary as a result of political experience is then a formation of political action and experience, which sets the character and tone of the future state and society: Une loi contre ceux institutions est tyrannique. ${ }^{301}$ In this vein, one can be led to ask whether the legislator as revolutionary creates via institutions, a society different from a society created by the political philosopher, or the person of quiet contemplation and reflection. The mythic or pseudomythic nature of many of Saint-Just's exemplars, e.g. Minos, Lycurgus, Numa, does not help us to answer this question, since to examine these in relation to traditional roles and modes of action of the political philosopher is problematic owing to the difficulty of establishing relatively certain information about them, or even a consistent mythology.

The banishment from the social as a punitive custom or rule within the institutional legislation of Saint-Just takes on a special dual role, with one role being that of future guarantor of the social law and social harmony. The other role, its role under exigent circumstances, is played out in relation to one of the foremost sources of obstacles to the Revolution as Saint-Just saw it; the Counterrevolution. The Counterrevolution in its actuality must inform Saint-Just's theory of institutions, and thus stand as one indication of actual political experience in a revolutionary circumstance being a prime determinant of a politicalphilosophical base. This active component of the social as begotten by the revolutionary can 
be said to be proletarian in origin in the sense that it replaces the impossibility of reflection for the worker with a new origin for thought, for political thought become social thought. In his protection of the social via institutions, Saint-Just goes further than banishment across the line of the au-dedans. The social, in the light of revolutionary experience, requires the placement of governors beneath the people, ${ }^{302}$ and thus in some fashion then attempts to strike out at bourgeois notions of representative governance, even if perhaps the particular guise of the revolutionary-legislator-philosopher remains with Saint-Just himself more or less bourgeois. The active element of the social in revolution, as the foundation of institutions, their creation in actual revolutionary urgency, and combat with the forces of the political reaches back to include a traditional theoretical component of the type that might be said to give the nod to contemplation of the 'political' fray at a distance. In fact, this quietude that political philosophy formerly required in some sense is, after exigencies of the day have passed, the goal of the social institutions formed by experience in the turmoil of action. Banishment from the social circle is in some sense a search for the peace that can bring about political philosophy, and a political philosophy that is more genuine insofar as the dishonesty of the ancien régime, whose component in the realm of exigency is the Counterrevolution, has had the condition for its possibility removed. The traffic in and out of the social circle which occurred in part as banishment of the rich, the intrigants, the aventuriers, and the clergy is thus consistent with both the purification of the au-dedans and with the distinction between the Revolution and the Counterrevolution. With reference to the tripartite division of theory, practice, and exigency, in the theoretical realm the sovereign is identical with the people; in counterrevolution the sovereign once again divides into prince and sovereign, with the king as the accepted repository of the idea of 'the prince'. In the realm of practice, social institutions maintain social harmony, the goal of revolution, while the counterrevolution is the maintenance of the disharmony of the ancien régime. In the realm of exigency, 
banishment comes to be necessary as a revolutionary strategy to reestablish the seat of society in the social; in counterrevolution, flight or emigration is the corollary of banishment, and the goal of the counterrevolution is the same as its goal in the practical realm, the mere maintenance of the displacement of political relations onto the social.

Expression of the Idea of the Civil Within the Area of Policy Institutional Foundation, Organization, and Maintenance

In the cadre of Saint Just as it came to exist at the end of his life, the Comités who were carving out the High Revolution and the future of France, Saint Just continued to write traditional political theory which appeared to have been related to the projects of his peers and thus, along with Billaud-Varenne, ${ }^{303}$ was the only political philosopher of the revolution writing from within its central government. His death occurred exactly at the point of pronouncement and implementation of a central foundation of the Revolutionary state - the institutions about which he had written. This foundation was cut in half in practically the most tragipoetic way imaginable, according to lore. ${ }^{304}$ The story of Saint Just's last speech to the Convention on the eve of his death has him being interrupted soon after beginning. ${ }^{305} \mathrm{He}$ would never speak again to the Convention. In the speech he was delivering at that moment, he was to attribute many of the problems that the Revolutionary state was facing to the lack of institutions, the institutions which had been described in his political treatises, institutions which he referred to as 'civil institutions'. 
Civil institutions were to do the work of maintaining the social realm and its lineage to nature. For Saint-Just, religious man was a type of denatured man. The denaturation that is manifested in religious law is a particular instance of the corrupted civil law's distancing of persons from nature and the social. The corrupted civil state separates thing from thing, person from person, whereas in the social they are a unity. The corrupted civil state separates man off from natural social affections in that this civil state, being as it is a result of the misplaced political, makes the divinity something feared: Mahomet...frappa son peuple de l'épouvante des enfers, par là il mit de la vertu dans l'état civil. ${ }^{306}$ Mohammed, however, was impious, according to Saint-Just, because no intermediary is necessary between the people and the divine. This, Saint-Just writes, is then in turn the pretext for creating obedience to a government that is alienated from the sovereign (the people), and the need for mechanisms of obedience that involve fear to Saint-Just is indicative of force, which is unnatural and unacceptable in an ideal society. The entire Cult of the Supreme Being can be seen, in relation to the philosophy of Saint-Just, as an exigent development, one in which the tension between the two forms of the civil (See Chart 1) is evident, and one in which the tension between revolution and practice is also evident. The Cult of the Supreme Being was brought about largely due to the revolutionary awareness of the possibly temporary problem of the loss of the, though corrupted, trusted elements of the civil. That is, the French people had anchored their society and identity to some extent in religious corruption in the form of the Judaic religions; the radical removal of these religions before the institutions of the social realm had been promulgated and established, and before their work of reinforcement could occur had left the people with an eradicated social base in their eyes, and yet with no replacement for it that had yet developed adequately. The revolutionary state could not survive without the support of the people, even if this meant the rapid creation of an artifice of the social in the form of a civil institution. 
The idea of institutions as civil as opposed to social speaks to the fact that the nurturing and maintenance of social relations was largely the province of the civil for Saint-Just. This is apparent in, for example, the fact that is the civil realm which regulates the social in its essence as property relations, or relations of individuals in society, while the social maintains a less concrete existence as affections. The social is of sentiment and unspoken understanding among persons of the au-dedans, while the civil is comprised of formative sentiments capable of being promulgated as civil institutions, or rather, as directives for the security of the social, sentiments such as those expressed in the first institution Saint-Just lists under the rubric 'Institutions morales': Le peuple français reconnâit l'être suprême et l'immortalité de l'âme. ${ }^{307}$ The protection, maintenance, and regulation of the social is then separated off from the social itself and is a duty of the civil. Although this is the case, the civil institutions which maintain the social, though they might be established by the legislator-philosopher as the functionary of the people and as the one who discerns corruption, do not require intermediaries or authorities within the ideal civil state:

Je vois l'homme partout opprimé par le prêtre et par les dogmes, mais ni les dogmes ni le prêtre ne sont la divinité.....La religion dit Montesquieu a sa racine dans le ciel, il se trompe, cette racine est sur la terre, il n'est point d'autorité légitime intermédiaire entre le ciel et l'homme, celui-ci peut s'appliquer la maxime des rois qui prétendent ne tenir que le dieu. ${ }^{308}$

Saint-Just apparently tried to maintain this removal of mediation of the people's will in the circumstances of exigency, as the civil state was being erected, and this is the light in which he saw the creation of the Cult. Mathiez reports that the Cult of the Supreme Being enjoyed wide popular support throughout the first half of Year $\mathrm{II}^{309}$ In his Fragments however, Saint-Just seems to want to allow for cults other than the Cult of the Supreme Being to be celebrated in the temples of the new society, though without priests as intermediaries. ${ }^{310}$ Since Mathiez also reports that the Cult of Reason and the Cult of Nature 
were widely supported, ${ }^{311}$ we can wonder whether Saint-Just was dealing with the problem of the discernment of the will of the people, and of its lack of unity during the period of the reformation by revolution of the French society. Here is represented Saint-Just attempting to act as legislator of the civil in the midst of the action of the forces of the political on popular opinion, and to perform the discernment proper to the legislator. Thus, we can perhaps make sense of Saint-Just's allegiance to the Cult of the Supreme Being as a civil institution of France that was in formation even as he opens the temples to all cults. Was Saint-Just's inclusion of provisions for the freedom of all cults not based on fear, that is, religious cults in the traditional sense (Tous les cultes sont également permis et protégés) ${ }^{312}$ and for those not mediated by persons acting on their own self-interest (Le prêtre d'aucune culte ne peut paraitre en public avec ses attributs, à peine de bannissement) ${ }^{313}$ to use the public temples an example of the problems of the rapid discernment of the people's will that revolution as a mode of legislation requires? Depending on when he wrote these foregoing words in the Fragments, we can also see the actions of Saint-Just as attempting to listen to the voice of the people in their actions of cheering and celebrating the various cults by looking also to others who might or might not be messengers of the people's will as the expression of the social. Such questions present to us the problems of rapid discernment and of rapid formation of theory by action and of action by theory. At what point in the formation of the civil realm's institutions did the Hebertists cease to represent the affections of the people? Mathiez's words express the deadly dangers of such juxtapositions and discernments: “c'était au moment même que les hébertistes montait au échafaud que de toutes parts les patriotes s'accordaient à souhaiter l'execution de leur programme religieux!"314 
Expression of the Idea of the Political the Area of Policy -

Institutional Foundation, Organization, and Maintenance

One of the ultimate goals of Saint-Just's political philosophy was to remove force from the state, and force for him was almost synonymous with the political. The demands of the revolutionary situation however, saw him strengthening the offices of the executive and increasing their power, even as his ultimate program for the ideal polity placed all governors below the people and below full citizenship. In the circumstances of the revolution and its movement, it became clear to Saint-Just, as it was to Robespierre that the first order of business had to be the survival of the revolutionary state, the guarantor of freedom and justice, and for Saint-Just, the guarantor of the return to the social as the proper realm and milieu of human interaction.

One situation where the demands of revolutionary exigency begat a seemingly contrary politic was in the creation of the War Ministry. ${ }^{315}$ The situation both on the front lines of battle and in Paris was serious. Speaking to the latter, Saint-Just said,

Le ministre est sans mesure et sans poids. Il n'est point le pivot de l'administration, il en est spectateur... la perfidie circule d'agents en agents jusqu' à lui; tout le monde se trompe réciproquement: le conseil executif est trompé par tout le monde..... les ministres échappent et vous ne savez où porter la main. Le fragile édifice du gouvernment provisoire tremble sous vos pas: l'ordre présent n'est qu'un désordre mis en lois ${ }^{316}$

Here, importantly, the ministry is different from the minister in its place in the system of principled and relational government: "Un conseil et des ministres sont deux choses hétérogènes et séparés. ${ }^{317}$ This is one element of the retention of the suspicion of the executive, of the magistrate, but in revolutionary exigency the magistracy is necessary, and thus in some sense the political plays another specific role in the revolutionary state which is related to its general role or function of the erection of the social state (See Chart 1). In the 
time of revolution, the political is a part of the government in that the government contains an executive which must have something like war powers. Revolution is in some sense then the tension between the social and the political being played out and, since the ideal is practical, the political is destined to be removed to its proper place. The existence of the political however in this mediation that is the state of revolution brings up the question of its influence on the institutions of the practical state that must be developed by the legislator in that state of exigency. The political philosopher as legislator as revolutionary must be one who is in a position of discernment as to where the various areas of relations stand with regard to one another, or, the cognizer of the political, even as he or she must mediate between it and the social in the interest of the arrival of the social. Revolution is a form of war, and the tensions between the political and the social play themselves out even in the organization of war itself, as this war that revolution is is then part of the ground for the development of institutions of the separation of the au-dedans from the au-dehors, of the maintenance of the circle. The question of whether or not the political will always be necessary or how long it will have a function with regard to the social is then also for SaintJust the question of the possibility of the end of war.

. Goods Production and Distribution -

Expression of the Idea of the Natural Within the Area of Policy

Rousseau sees morality as unnatural. Saint-Just wants to preserve a part of morality as 
natural, and does so in his description of natural morality, which topic he introduces specifically at one point with regard to the economy: "...je passe à l'examen et de nôtre économie, et de nos mours." ${ }^{318}$ In Saint-Just, although there is a politic of circumstance, it has a continual rapprochement with a theory of justice, such that circumstances are not entirely determinative of justice. Circumstances are always connected to theory, and judged in relation to the ideal society. However, circumstances can themselves be determinative of theory. The very idea of alignment to nature can be seen as a product of historical circumstance, since even the concept of nature itself might be seen as historically produced, even by economic circumstances specifically. ${ }^{319}$ If the tenure of a concept's sense and common understanding is limited historically, one might place Saint-Just at a moment where morality is still tied to the concept of nature, yet one where the idea of social relations as a central focus has already come into consciousness.

The maintenance and nurturing of natural morality, which consists in such things as friendship and love, is the work of civil institutions, while the reestablishment of this natural morality and its attendant social relations is the task of the Revolution. In the area of economic policy as elsewhere, Saint-Just desires to make the intermediary correction as swift as possible: "Lever tous les tributs, en un seul jour, sur toute la France." ${ }^{320}$ The treatment of the economy in the Fragments occurs prior to the precise and formal specification of institutions, and is absent from this latter part of the Fragments. Even though the Fragments is incomplete, it is consistent with Saint-Just's theory that the economy and this moral connection would warrant a discussion outside the section of the Fragments which specifies institutions, since these institutions are meant to maintain and nurture the social relations, while the Revolution is the means back to nature, out of which these social relations still arise in Saint-Justian theory. ${ }^{321}$ More specifically, Saint-Just iterates a reasoning for this 
organization: "La question du bien général doit être posée sous tous ses rapports, afin que tout agisse et réagisse avec harmonie. "322 Thus one might be warranted in seeing in SaintJust a stage of consciousness that is attempting to go further to connect the idea of social relations to the economic particularities, and thus the descriptions of the social law as property and of the civil law as possession. Nature, though, remains the ultimate litmus of the moral socially for Saint-Just, even if its obviation is portended.

Relations are the form in which the constituent elements of the social realm occur, and, with the relations of the social realm connected back to the relations of the natural realm, the social realm takes the place of the political realm; thus, it is the social relations that must be honored, understood honestly, and guarded. In the actual state, a state where hoarding is taking place, the civil relations, which are relations between needs, are corrupted, and this corruption has tainted the social relations, the relations between individuals:

Les monnaies étaient resserrés, les denrées le furent aussi: chacun voulut mettre â l'abri ce qu'il possédait. Cette défiance et cette avarice ayant détruit tous les rapports civils, il n'existe plus, un moment, de société. ${ }^{323}$

There is a false morality with civil and social origins and manifestations, and this unnatural morality is based on fear, ${ }^{324}$ fear that derives ultimately from the au-dehors, the realm of the political.

Though Saint-Just reverses Rousseau's order of savage-civil, and claims that 'civil' society was the commencement of savagery (and unnatural morality), there is still an echo of Rousseau's designation of all morality as unnatural and the production of convention in Saint-Just's discussion of morality. This echo of Rousseau is found specifically both in SaintJust's imputation of the origins of the unnatural morality to exteriority, to the au-dehors, and also in Saint-Just's connection of morality to the land and to egalitarian subsistence farming. ${ }^{325}$ Movement away from the latter Saint-Just then treats as a corruption or 
destruction of the proper civil and social, and as something which must be rectified by the Revolution, though the focus of the institutions which the Revolution will establish is on the maintenance and nourishment of social relations which are already moral, that is, which are natural, in that they are based on such natural social relations as love and friendship. Thus, only natural morality is treated by social institutions, which sustain natural social relations, after the Revolution has purged the elements of the au-dehors from the au-dedans. Thus again, the treatment of morality is for Saint-Just a revolutionary treatment and comes into being as a time of exigency, that is, during the expurgation of the political. One senses in Saint-Just the fear that giving importance to morality as a concept also gives rise to considerations of immorality, and that the entire business of such considerations is a corruption, albeit one with which the philosopher-legislator, in his or her task as revolutionary, must traffic.

In a natural social state, there is already satisfaction of wants and needs, which are tied to the land. This tieing to the land, with land as the base of morality also makes derivations therefrom, such as financial interests, based in immorality, and indeed this immorality is described as the desire to "étendre le champ". ${ }^{326}$ The land, egalitarian ownership thereof, and the corruption of this state are important nodes of the moral for Saint-Just: "...je passe à l'examen, et de nôtre économie, et de nos maurs. Ces deux choses sont pleines d'analogie; on ne peut guère les traiter séparément." ${ }^{327}$ Therefore, "Pour réformer les mours, il faut commencer par contenter le besoin et l'interêt; il faut donner quelques terres à tout le monde. ${ }^{1328}$ The return to nature is then the return to morality is then the return to land, but unlike in Rousseau, property (propriété) does have an original, natural, moral element. Since equality is natural, and inequality unnatural for Saint-Just (See Schematic 2), government policy would seek what is natural, and thus would seek equality. The redistribution of the 
goods of the wealthy which was part of the decrees of Ventôse, which Saint-Just was charged with presenting and pushing through ${ }^{329}$ was then an attempt by the government to realign with nature. The natural practice of equality being so far from actuality, a readjustment was necessary in order to achieve justice and to bring the polity closer to the natural.

Expression of the Idea of the Social Within the Area of Policy - Goods Distribution

In the proper relations between possession and property, possession is the civil law, while property is the social law. Thus, Saint-Just's delimitation of the social in its aspect as "law" 330 leaves this aspect of the social with a broad enough definition that the particulars of the social relations within the domain of property, that is within the territory of the society as independent from other societies and within each and every self as an independent person, still have a wide range of possibilities for their particular content, though property ${ }^{331}$ as a term no longer has the same sense as it had theretofore. Some of that particular content however is filled in by the actions of Saint-Just and other Revolutionaries in the exigent circumstances of revolution, and this further specification of what kind of society France might be under a regime of the social, that is, as a society of social relations, acquires a fair amount of its particularity in the area of the economic, and particularly with regard to the question of the distribution of goods.

Albert Soboul discusses the question of Saint-Just's thought and action with regard to the redistributive Decrees of Ventôse, which were authored and announced by Saint-Just, and concludes that the thought of Saint-Just was not indicative of a new revolutionary program, as Albert Mathiez had argued, ${ }^{332}$ but rather a continued bourgeois line on distribution. ${ }^{333}$ Saint-Just's theory of property makes it difficult to argue for Soboul's position, at least with 
regard to the purely theoretical aspects of Saint-Just's work on distribution of goods, and further, even though, as discussed in the section following, some of the notions of traditional property are preserved more in Saint-Just's idea of possession, the law of the civil state, the particulars of his revolutionary action referential to the latter, again, especially in the area of goods distribution, indicate a conception of property in general which cannot simply be understood as bourgeois, reformist, or liberal. In addition, other authors, who have approached the study of Saint-Just from different perspectives and with different questions, have averred in their understanding of Saint-Just as having moved beyond liberalism in his policies and also as having moved beyond a merely bourgeois consciousness. ${ }^{334}$ Mathiez in fact declares that with regard to the redistribution plans of the Revolutionaries, in relation to whom Saint-Just is seen as more radical by virtue of his "Decrees of Ventôse", that "la pensée communiste se réalisait." 335

The Decrees of Ventôse and Saint-Just's arguments in favor of them were hardly brought about in a direct way, but rather under contextual circumstances that make any traditional idea of implementation from theory irrelevant. The issue at hand when Saint-Just took up the defense of the confiscation and redistribution of the belongings of the rich and of the indulgents ${ }^{336}$ was the maintenance and stability of the revolutionary government, and for such goal a redistribution, long called for by the sans-culottes and others, had reached the point of inevitability. This, at least, is the narrative of Soboul and others. ${ }^{337}$ But again, we have Saint-Just's property and possession theory to call to question this narrative. Certainly the circumstances of the emergence of this policy were exigent, but what role did this exigency play and what was its character, especially in relation to Saint-Just's political theory? Was the politics of exigency actually the politics of Robespierre, while Saint-Just remained steadfast in his charge to back up the revolution with the articulation of its spirit? Saint-Just's 
integrity in fact certainly has a significant traditional portion, whether his theory exists as an apologetics of the ideology of Robespierre, as the articulation of the revolutionaries' thought, it can still be seen ultimately as the translation into theory of the actions of the poor, since the ideas of the revolutionaries were forced into actualization by the activity and situation of the lower classes, and this actualization necessitated a theorization as both justification and future ground for political-cum-social philosophy.

Even if one considers Mathiez more correct than Soboul in his assessment of the redistribution plans and policies of Saint-Just and the Revolutionary government, Soboul still captures the essence of the historical moment of consciousness with regard to the Revolution in general, and further Soboul brings up specifically revolution's role in establishing political thought which develops a "social" character:

Que les décrets de ventôse aient constitué une mesure politique, c'est certain; ils n'ont pas été autre chose aux yeux de la plupart des conventionnels et des membres des Comités. Mais ils entrent sans aucun doute dans les vues sociales permanentes de Saint-Just et de Robespierre. ${ }^{338}$

The "political" to which Soboul refers, however, carries the sense of actions that are expedient and of the moment, and, along with this, the sense of their being produced in conditions of force; thus, this sense of the political comports with the sense of the disparaged political in Saint-Just, but Soboul does not make this connection. The struggle to define the social out of and away from the political, which Saint-Just's work and much later work in a radical tradition attempts to do, is then abetted here in Soboul's argument in that it is the social aspects of the traditional political, which here must mean its aspects which are free from the relations of force and also its aspects which are brought into the realm of consideration by political-philosophers as Rousseauian-Saint-Justian legislators by the proletariat, which form the revolution. The social is distinguished from the political in 
"social history" and elsewhere by the origination of its questions and issues, and thus its composition by "the people", that is to say, by the working class. The proletariat's composition as unphilosophical in the traditional sense, combined with its forcing of questions, thoughts, and actions to the "political" fore through popular revolution not only imbues the social with one aspect of its meaning in contradistinction to the political, it also demonstrates one way in which political-philosophical questions, issues, and treatments are produced. Saint-Just gives a political-philosophical justification for the actions of the proletariat which attributes justness to their actions by effectively labelling them properly social rather than political. The only valid force for Saint-Just is social force acting against political force. Arguments which portray Saint-Just more as a bourgeois reformer than as a revolutionary do not properly consider or perhaps understand Saint-Just's conception of the social, in which property exists in nothing like its traditional sense, but rather as “[propriété] de soi-même et celle de l'empire ou du territoire." The proper consideration of Saint-Just as not in any important sense bourgeois, as evidenced in the combination of his theory and action is however perhaps less important than the attempted transcendence of class that Saint-Just evidences, and which might be said to be appropriate to a political-philosopher as legislator. The Decrees of Ventôse though, and other programs of and views on distribution and redistribution of the goods of the society have to do not so much with the Saint-Justian idea of property, which is the social law, but rather with the kind of traditional property that is still preserved in some sense in Saint-Just's conception of possession as the law of civil society. 
Expression of the Idea of the Civil Within the Area of Policy -

\author{
Goods Distribution
}

The practice of a civil state that is founded on the principle of equality and has possession as its law, ${ }^{339}$ when compared to the actual civil state in France at the time of the Revolution, required a swift and immediate rectificatory and redistributive justice as inspiration and corrective, and, more urgently, people were malnourished or starving. Much of the policy regarding distribution of goods before the Decrees of Ventôse was not as rectificatory in its degree or radicality, and prior policies were more consistent with a stable government which had already achieved some degree of redistributive justice. The redistribution policy in the Decrees of Ventôse was a policy which aimed at immediate and radical change and justice, and thus was the most salient revolutionary policy in this area.

This real or true civil state (Civil 1) however, was not the actual state of Saint-Just's time, but the state to which revolution could bring the society. In the matter of the distribution of goods, with goods being understood in a general sense which includes all things desired, and both personal and real property, Saint-Just favored a just and equal distribution of agrarian assets, and this, in fact would for him be sufficient in itself to constitute a revolution. ${ }^{340}$ The main obstacle to the achievement of this revolution was, in theory and in actuality, commercial and speculative interests, which he stood in contradistinction to subsistence and the simple meeting of basic needs. The corrupted civil state (Civil 2) was then seen to be almost coterminous with financial dealings and speculation. Opposite what he saw as natural and productive of harmony and natural social relations, that is, as opposed to an egalitarian system of small scale husbandry, shopkeepers and craftsmen 
are even at one point the brunt of Saint-Just's criticism. ${ }^{341}$

A return to a civil realm which consisted of laws founded in social relations and of government by institutions which maintained those social relations would necessitate a purgation of illegitimate commercial interests. In Revolutionary practice, that is, in the actual state of affairs, the problem that arose overall with the radical program of redistributive justice which the Revolutionaries eventually undertook was that all programs for redistribution turned out to allow bourgeois speculators to move in and take advantage of them, contraverting their intended effect. This problem made more stark the need for natural social relations to replace the corrupted relations among persons that would allow for such misuse and contravention, and yet the very ingenuousness which Saint-Just's revolutionary program of social institutions was attempting to reinculcate seemed paradoxically to be a necessary condition for its own establishment through these institutions. Seen in this light, the punitive measures undertaken by the Revolutionary government make sense as an attempt to replace, under emergency conditions, the mandatory ingenuousness with regard to unity and equality that the social law required, enforced, and would eventually guarantee. Thusly can one make sense of the severity underlying Saint-Just's careful attention to the development and presentation of his arguments for the arrest and trial of those perceived to be counterrevolutionary even as he knew where his rhetorical efficiency would lead. Similarly, one can make sense of Georges Couthon's mocking contempt for the beliefs of the traditionally religious as he gave the clergy the option of being shot, deported, or of becoming secular functionaries; ${ }^{342}$ of Jean-Henri Voulland's daily presence at the revolutionary tribunal and his heckling of those trying to defend themselves against imminent incarceration or death. $^{343}$

The only way out of the paradox of the need to have in the first place a morality that 
revolutionary social institutions would bring about was seen to be severity in punishment, in hunting down disingenuousness, in chastising even its enablers. The innocence of this position is what is striking; a base, a vision, of simple, pastoral equality and peace that is even quaint and picturesque from the perspective of the corrupted civil state's citizenry as a motive for revolution. Integrity as a virtue, the correspondence between theory and action as moral, was actually evidenced very consistently by those who were in charge of punition in the name of the Revolution. Thus, those members of the committees of Public Safety and of General Security who survived Thermidor virtually all remained loyal to the Revolution for the rest of their lives, many dying in poverty, in hiding, or in exile, and thus paying dearly and permanently for their ideal. ${ }^{344}$

The purgation of improper commercial interests as necessary for internal peace, unity, and equality is seen by some as a demi-recognition by Saint-Just of the unfolding historical circumstances $^{345}$. The argument is that a full recognition of the industrial phase of capitalism's unfolding would have necessitated policies that took this into more full account, but also that such a recognition would have been fatal to an ideal of agrarian subsistence. ${ }^{346}$ This argument is really an adducement of the idea that ideas themselves arise from historicalmaterial conditions. In relation to this idea, the dialectical tension of Saint-Just's sociopolitical existence comes into prominence on two levels. One of these is Saint-Just's recognition of the impending industrial revolution in his ideas about the corruption of the civil realm, and his desperate attempt to return to a former state. Another is his desperate attempt to hold onto the idea that political theory can be both impervious to these conditions and can exist as non-circumstantial and eternal. Saint-Just actually promotes neither of these positions, and in fact embraces the tension that he himself is, refusing the idea that a return to an ancient realm is possible or desirable, and also effectively equivocating on the question of 
the temporal order of theory and circumstance.

In his aspects as political actor and theorist, Saint-Just responds to these dynamic tensions by attempting to transcend historical notions of property, thereby distinguishing the civil realm from the social realm but also thereby pointing to a kind of sociohistorical pathology or historical error as corrigible. Revolutions thus have the potential to become that which corrects historical errancy, an historical error being comparable to a dialectical moment, with the political actor being the historical actor, and the actor now oxymoronically being the manifestation of la force des choses. The tension between ideal and actual, between correct and corrupt, is actually most evident in the civil realm, which itself exists in the theory of Saint-Just in a bifurcated way, an existence which might be said to evidence the medial zone between the ideal and the actual. Saint-Just can be understood to be filling in a dialectical antipode, one which is in the process of becoming, and one which redefines property, circumscribing it much more narrowly and basically, and thereby correcting an immanent dialectical tendency.

Is equality, the principle of the civil state in Saint-Just, beyond historicity though? Insofar as a desire for equality has always existed among peoples in societies, the ideal of equality might antedate even fundamental concepts of the conceptual landscape of political philosophy, concepts such as nature. As such, equality perhaps must be, and is, a problématique of political philosophy. Thus, whether in slave revolts or in organized worker uprisings or otherwise, equality must be addressed by the political philosopher. One way to end the problématique of equality is to actualize, or realize it, such that it becomes the precondition, or at least the foundation of the future landscape of political-philosophical questions. Insofar as revolution has a radical and progressive tradition which has desired to realize equality, we can see Saint-Just as a political philosopher who attempts to put an end to 
the problématique of equality. To do so, he creates a theoretical architecture of the civil state in practice which assumes equality as premise and principle. Possession posited as the law of the civil state in practice denies the verity of the hyperindividuated physiocratic and liberal notions of equality as the freedom to exploit others, often attendant in concepts of selfinterest and "free" trade and markets, by connecting possession to equality, to that principle on which it rests, and yet it does so within a political philosophy that uses the terminology of property. Saint-Just's belief in equality comes both from a theoretical tradition which valued equality and spoke of it eloquently, and also from the mandate of the people to narrow the gap between classes.

With equality having had such a long existence within political philosophy as an ideal and problématique, and with inequality having such an old pedigree, the political actor as revolutionary is wont to be severe in suppressing those who validate inequality by acting on a self-interest that is based on altogether different ideas about possession and property than the ones Saint-Just puts forward. This severity in Saint-Just's experience can be said to be mandated by revolution's tradition of radicalism and progressivism, it being the character of the action required by a political actor to end the regime of inequality radically, that is, quickly and thoroughly; together the revolutionary program of suppression of those who flouted equality as a principle and the theoretical justification for equality, its placement in the definition of the civil state, can be seen as forming an approach to the problematique of equality for the political-philosopher as legislator and implementer. The exigent circumstances of the attacks on the regime of implementation, on, that is, the revolutionary regime, were the result of the lack of a proper civil state already being in place, since if such a civil state were in place it would guarantee that all commercial activity would hold equality as a principle. Hoarding during the Revolution, which formed a significant part of the basis 
of Saint-Just's view of economic problems and distributive justice ${ }^{347}$, was done by those who were both exploiting the people and attacking the Revolutionary regime, and this experience helps create and define Saint-Just's economic critique and forms an important part of his political-philosophical attempts to provide for a future without such anti-social behavior. The policies of Saint-Just and the other Revolutionaries with regard to distributive justice are in the interest of equality practically. This and the theory of the civil realm as the realm of a commerce of possessions always in the service of the principle of equality are concomitances which comprise a radical answer to the set of questions which form the problematique of equality in the political-philosophical tradition.

Expression of the Idea of the Political Within the Area of Policy Goods Distribution

A full understanding Saint-Just's conception of the political would necessarily comprehend a Saint-Justian society as a so-called "closed society" ${ }^{348}$, and his ideal state in practice would necessarily have to be one such. Analogous to the later attempts by so-called closed societies to protect themselves from what they saw as destructive forces is Saint-Just's earlier attempt to remove exploitation and all relations of force from the au-dedans. This attempt is particularly revolutionary, in the sense of there being a need for immediate correctives such as banishments and proscriptions of foreigners and their operations that would be destructive to the republic envisioned and being created, and thus here as elsewhere 
'revolutionary' for Saint-Just is, or at least has an important dimension as, exigency. Even prior to the treacheries Saint-Just experienced during the Revolution and especially after the writing of $L^{\prime} E s p r i t$, the need for such a society is expressed in Saint-Just's exteriorization of the political, but this need becomes more poignant after the exigencies of Saint-Just's experience as a governor in a time of revolution. If much of the Fragments is properly understood as a late and unfinished work, the words used therein befit an author who was been worn and beaten down by treason, by outside forces, thus, by the political. With regard to the particular area of subsistences, there is testimony to this desire for closing off from this treachery in a way that is absolute and severe, and yet which provides for future practice in its politically proscriptive prescription for social institutions: for example, again, "Nul ne peut acquérir de terres, former de banques, ni entretenir de vaisseaux en pays étranger. ${ }^{1349}$ Thus, Saint-Just at the time of the Fragments, even as he is wearied and weathered by political treason which he understood to be brought about through factions created by foreign intrigues ("les factions triomphantes un seul jour....ont jetés dans la nuit éternelle [les hommes grands]malgré des années de virtue") holds to the helm of the ideal future state and its practical guarantor, institutions: "les institutions sont la guarantie de la liberté publique.....elles repriment les jalousies qui produisent les factions. ${ }^{1350}$

In Saint-Just though, there is not yet a developed ideology of exclusion of markets, and yet this seed is present in the policies he both prescribed for the practice of an ideal state, and in those he enacted, such as the redistribution of the goods of the clergy (the clergy were understood to be particularly connected to the counterrevolution outside France) and the regulations on subsistences. The closing off of society from external damage in the work of Saint-Just is already deeper than, as well as something other than, an anti-market ideology, and yet it is a precursor to it in its aspect as his thought as it is in his action, the latter of 
which more actively served as inspiration for later so-called closed societies. ${ }^{351}$ In Saint-Just this practice receives an early and powerful, even moving political-philosophical adumbration in the conceptualization of the political and its place in relation to the social, the civil, and the natural, a visualization of perfection in Saint-Justian ideals of practice, and then a corrupted instantiation within the exigencies of the Revolution.

Despite the fact that the action of the Revolution while it endured was often an effort to close off France from the influence of foreign powers, from the world, from the political as Saint-Just defined it, Alexis de Tocqueville's theory brings out a seeming irony in this action by arguing that the French Revolution was a "political" revolution ${ }^{352}$ but that it distinguished itself from other revolutions by being the first universalizing revolution, the first revolution to speak, as it were, in universal terms. In fact, Tocquevillian theory is instructive when compared to the theory and experience of Saint-Just both in terms of the differentiation between the political and the social and in terms of the consideration of a relationship between theory and action. The irony that Tocqueville's position brings up is found, on further inspection, not to be such. Tocqueville, without naming the distinction between the social and the political specifically, but rather opposing "religious revolution" to political revolution actually argues for the social character of the Revolution:

The French Revolution acted, with regard to things of this world, as religious revolutions have acted with regard to things of the other. It dealt with the citizen in the abstract, independent of particular social organizations, just as religions deal with mankind in general, independent of time and place. It inquired, not what were the particular rights of French citizens, but what were the general rights and duties of mankind in reference to political concerns. It was by thus divesting itself of all that was peculiar to one race or time, and by reverting to natural principles of social order and government, that it became intelligible to all, and susceptible of simultaneous imitation in a hundred different places. ${ }^{353}$ 
Tocqueville effectively describes both the Revolution's true intention and its outcome as social, ${ }^{354}$ and thereby helps to fill in a theory of the social as distinguishable from the political. Without concretizing the distinction, Tocqueville distinguishes the social from the political in a way that is similar to its distinction in Saint-Just, and yet Tocqueville's theory is somewhat different from that of Saint-Just in its full elaboration, and also different with relation to Saint-Just's revolutionary experience, especially in the area of the economy and distributive justice.

Social revolution in Tocqueville, as it were, is based on ideals, on such things as cultural ideas and religiosity. Sheldon Wolin effectively describes how it is in Tocqueville's examination of questions about the relationship between theory and action that Tocqueville develops a theory of the social, even as a conceptual semi-conflation of the political and social still exists: ${ }^{355}$

Tocqueville chose to approach the problem of theory and action not as Marx would by situating in intimate relationship with the material forces of the world, but by way of a discussion of the potential power resident in "ideal" factors, specifically, in the status and character of literature and history.... 356

Tocqueville's description of the French Revolution as a religious revolution in L'Ancien Régime et la Révolution is consistent with these views as they were developed in De La Démocratie en Amérique, with religion being from both the realms of the ideal and the cultural, and thus of the social realm. The universal language of the "religious" French Revolution for Tocqueville is considered to be "proselytization" and his definition of such as it describes the Revolution as unique with regard to this criterion. ${ }^{357}$ However, in Tocqueville there is an overemphasis on this uniqueness, which clearly cannot stand in the light of, for example, the same universalistic language appearing in the English Revolution. ${ }^{358}$ Saint-Just makes the distinction between the social and the political more 
express, and his articulation of the political helps to define the social by contrast. Saint-Just's critique of the political also comprises the essential elements of his theory and action with regard to distributive justice, since he divides the causes of economic and distributive injustice in accordance with their alignment with the political. The strict separation and express articulation of this separation of the social and the political in Saint-Just is the imperative for Saint-Just's consequent revolutionary action, while Tocqueville's action as a governor, if one can presume that this action involved an attempt to act in consequence with his political observations and developing theory, remains reformist. While the exteriorization of the political in Saint-Just is not the only way to attend to social needs and to the creation or recreation of social harmony, it is radical, and as such is the corollary theoretical component which justifies the kind of revolutionary action which Saint-Just took, action for which Tocqueville's social theory, especially its economic aspects, provides some justification. Tocqueville though, regrettably according to André Jardin, lacked the revolutionary's ability to immediate establish justice. ${ }^{359}$ Saint-Just legitimizes this immediate rectificatory justice in the matter of redistribution by isolating the relations of disharmony and injustice in the domain of the ostracized political.

Saint-Just and Tocqueville then are really two theorists of the social, a social whose content is defined by its distinction from the political. If we consider Tocqueville and SaintJust with regard to the historical trajectory of the of the concept of the political, we can put them in some sense together as theorists of the immanence of the social as a concept arising in distinction to the political, perhaps as its negation. While both theorists place importance on the social and the ideal, Saint-Just, in the combination of theory and practice that his life was, pays a different kind of attention to the material factors determining the social situation than does Tocqueville, the attention of one who is invested in the creation or reification of the 
social, rather than as one who observes it in the liberal-conservative manner of scholarly disinterestedness and administration of reform justice in the administrative apparatus of a spectrum of liberal-conservative regimes. Saint-Just's attempt, as revolutionary, to create swift and immediate justice via redistribution and reestablishment of natural maximums and minimums in this area, is an act that is essentially revolutionary, and it is on the long wake of such revolutionary actions that reformist logics play themselves out, theorizing and administrating. Tocqueville's characterization of the French Revolution as universalist is similar to Saint-Just's tieing it to nature, and to a past state of harmony, and thus both are idealistic, and yet Saint-Just, acting out of a combination of idealism and of practicality in the form of implementation of a political philosophy, creates, or tries to make manifest, one might say, conditions which will shift "political" realities. These very attempts reinvigorate the ideological persistence of developing theories of social justice such that liberalconservative theorists' agendas of moderation and disproving of radical change are themselves reinvigorated. Tocqueville's political life, occurring as it did in a century of reaction, not surprisingly carved out its existence antipodally in relation to the French Revolution in some sense, and yet the combination of work and thought in a counterrevolutionary context and a genuine desire to understand the shifting political terrain even as he carried out a reformist agenda made possible by the example of the Revolution is perhaps what made Tocqueville's work evidence some consciousness of the possibility of the social's emergence in contradistinction to the political, an emergence which Saint-Just's theory and action make more express and reified, especially through its actions with regard to distributive justice.

Revolution serves for its active participants as a closing of the distance between theory and action, and Saint-Just's active involvement in implementation of ideals in exigent 
conditions disallowed the kind of mysticization of both the Revolution itself and of the relationship between theory and action which Tocqueville's thought evidences. Saint-Just as a revolutionary actor could and did specify the obstacles to revolution's ideals, and thus a correspondence between theory and action does not appear to be an illusion to him as it did to Tocqueville who, despite his government service, gave greater validity to the theory in its fully separated and purely observational aspect. Tocqueville's work contains the elements of a radical economic critique, but Tocqueville is reluctant, in his class position as aristocratic governor distanced from the people with regard to class, to move an analysis of the social into an active concern for the people which attempts immediate rectification. We might then say that the extent to which Tocqueville abides the political in its Saint-Justian definition, that is, insofar as his class preference for the validity of aristocratic historical observation as theory with its distance from active redistributive justice which could never fully allow for the realization of an ideal of justice, is the extent to which the question of theory and action must have answers which remain purely in the domain of the mystical or abstract, and it may also be the extent to which Tocqueville failed "to work out a satisfactory conceptual framework for the Revolution's actual events." 360

Revolution -

Expression of the Idea of the Natural Within the Area of Policy

Saint-Just, in his Speech on the Constitution of Year I, said that the constitution must not be a weak one, and by this he meant that it must provide laws rather than precepts; this in 
turn meaning that the constitution must not be vague and thus subjectible to the kind of manipulation by the aristocracy or clergy which might exist in some fashion or develop even as the republic was being established, and even as those of the ancien régime were being eradicated. Thus, the Constitution of Year I was to be a product of revolutionary exigency, which exigency and its fruits become the guarantees of the future smooth running of the civil state and the guarantees against the prince's usurpation. Exigency here as revolutionary practice then plays an important foundational role in its assurance of the purity of the state being established. Exigency as revolutionary experience creates a rapid awareness of the problems of contravention of laws, allowing for the incorporation of this knowledge into the theoretical justification for the laws, and also allowing for a theory of justice to be developed from within a milieu of active experience, albeit a theory of justice which remains only implicit in terms of formal theoretical speculation and examination. The purity of the established state in practice is perfect justice, which for Saint-Just existed in an original state of nature.

In his argument in the Speech on the Constitution of Year I, Saint-Just speaks against 'precepts' being the stuff of the Constitution and this might be taken as another denigration of theory and also a denigration of an abstract idea of justice. Yet, precepts do not necessarily emerge from theory, but can be the product of active political experience or of other things. Saint-Just's call for the express in the form of laws rather than precepts is here based on his experience of the 'political', which saw the manipulation of preceptual directives by the aristocracy. In looking at what Saint-Just is calling for in this speech, a line of movement can be drawn all the way from the state of nature through revolution as a temporary corrective to the Rousseauian end of a society which would need few laws, or in Saint-Just's more extreme ideal, no promulgated laws at all, much less specific ones (Diagram 4). 


\section{Diagram 4}

\section{The Notion of Law in Saint-Just in Its Temporal Progression}

State of Nature/Original Social Law - Social Law Known in the Heart, Naturally

Corrupted Social Law Produces Constitutions of Precepts

Revolution: Reestablishment of Rapports Sociaux Produces Constitutions of Laws

Rule of the Loi Sociale

Few or No Laws, End of Written Laws

Thus there is a full spectrum movement here from the laws that are known to all by heart, ${ }^{361}$ through a period of corruption and its corrective, and then back to the rule of the social law, all of which is a realignment with nature for Saint-Just, nature being the base to which he attached the a priori, the ultimate referent of governance. Revolutionary exigency, however, forces the initial manifestations of natural justice to be found in express laws which are severe and directed with particularity against the enemies of social harmony.

When one looks for a place for political philosophy here in the development and justification of a constitution for France, one finds its entrée is from the realm of popular action and direct democracy, and that its placement is actually in the area of the corrective, the time of the revolution, the category of exigency, as justification for the practical laws which are born of the experience of a regime in which the convention of government was a contravention of the natural. Exigency, in the terms of the traditional political, is the state of action par excellence, and this state is placed by Saint-Just as prior to a speculative 
philosophy in whose result Saint-Just discerns a lack of discernment:

Il m'a paru que le comité [de constitution] avait considéré la volonté générale sous son rapport intellectuel; en sorte que la volonté générale, purement spéculative, résultant plutôt des vues de l'esprit que de l'intérêt du corps social, les lois étaient l'expression du goût plutôt que de la volonté générale. ${ }^{362}$

Even as one sees that Saint-Just clearly did do political theory and clearly did have in mind, at least in part, a progression from theory to action, one feels, in looking at this succession and also at all of Saint-Just's political life, that there is also a writing backwards from exigency, an ex post facto philosophical bent and attempt, and yet, there is also the feeling, a result of examination of the evidence, that Saint-Just is clearly more than a propagandist, a rhetorician, or an apologist, such that critiques of Saint-Just's work made as the result of this may not adequately do justice to the drive to do political philosophy. Any dynamic tension in the political life of Saint-Just with regard to political philosophy may have to do with this attempt of the philosopher to transcend class, culture, and history, but especially with the attempt to bridge the temporal gap between ideal and real, between the speculative and the actual. This tension continually shifts the order of theory and "political" action in the time of revolution until this continually reversed juxtaposition is, for Saint-Just, ended with the merging of theory and action with reference to a state of nature, movement toward which is itself a backward movement through historical time. As the natural is revived via the correction of revolution, itself comprised of theory and action, historical time can be described metaphorically as an unfurled ribbon which folds back on itself, only to fold over again on top of this backward fold and roll forward once more. The political philosopher, in accordance with Saint-Justian theory, is the one who creates these folds in the ribbon, which are representative of legislative corrections to society, which corrections are made possible 
by revolutions in whatever form they take.

Expression of the Idea of the Social Within the Area of Policy -

Revolution

The purification of the government for Saint-Just is the same thing as movement of the government toward the social is the same thing as the movement away from laws and toward justice, is the same thing as the government becoming thoroughly revolutionary. And, what does a revolutionary government look like in practice? This question is complicated in that, in the ideology of Saint-Just, it is clear that revolutionary government is both procedural and substantive. This is in fact a contradiction in Saint-Just that forms the basis of his importance and value. While he, many times over, describes the Revolution in terms of its being a temporary corrective, he also continues to imbue the idea of a revolutionary government with substantive content in the form of theoretical underpinnings and justifications, with laws, and with directives. Is it the case that, even without the intention of its being so, the specific content of the revolutionary government, even as it is forming, is coming to life as a separate sociopolitical phenomenon, as something which goes in some sense beyond its intention and something which acquires a reality and perhaps a value that cannot be ignored, or relegated simply to the realm of the intermediate? This seems to be the case in the combination of Saint-Just's thought and other work, and this fact is what presents a Hegelian aspect to his full experience. The Hegelian dialectic, as much as its common and cursory explanation is binary, really involves a chain of negations, such that ' $A$ ' becomes 'not $A$ ' and 'not $A$ ' becomes 'not not A', historically. The movement and its 'moments' or negations, are not ultimately and properly divisible or comprehensible as discrete parts, or even analytically. Thus, the

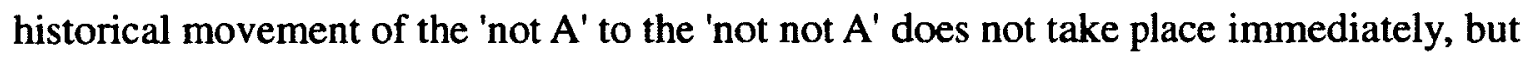


rather unfolds, allowing for many elements of the 'not $A$ ' to be present still, temporarily, in the 'not not A', elements which may themselves form the bases of historical and political knowledge, and in turn be used as templates for the further development of such. In short, Saint-Just's experience is a dialectical-historical 'moment', but one which continually helps us to understand the entire process of unfolding. Thus, what a 'utopia' is, what the full return to the social is, in Saint-Just's theory and in his action directed theretoward, is a goal, a something, an 'A', which is only now understood, retrospectively, to have been this ' $A$ ', and to subsequently have been subsumed by its negation.

Need this historical movement be teleological though? To Saint-Just's consciousness it primarily is not; however, he evidences a dialectical tension between the idea of his sociopolitical existence being due to historical circumstance, and the idea that revolutionary action, that is, the actions resulting from historical conditions, are themselves what produce historical conditions, and perhaps even what produce the idea of historical conditions as determinants of sociopolitical 'reality'. Briefly then, the experience of Saint-Just anticipates the contradictions of Marxism, and his "political" existence evidences them avant la lettre. . But whether Saint-Just believed that his actions were historically determined and inevitable, 'la force des choses', or whether he believed in free will, or some combination thereof, SaintJust would still have acted to bring the social back into the polity, that is, to make the social again the polity. The question of how the break from the social comes about and how to return to it would still be the question of the day, as it were, or the question he had to pose to himself in determining his actions.

Exigency (revolution), on the one hand, is the demand for its own disappearance. In order for this revolution to disappear, its purity as a negation of A must be achieved. This disappearance is the same thing as the disappearance of the corrupted civil state. In the 
Revolution, or in the period of Revolution, which is still a period of corruption to the extent that it has not yet achieved the social harmony of the state of social relations, "tous les ennemis de la République sont dans son gouvernement. En vain vous vous consumez dans cette enceinte a faire des lois. ${ }^{1363}$ On the other hand, the revolution, as it comes to be and executes itself, inevitably develops a substantive content of some sort which wants to continue to assert itself beyond its temporary function. One way in which revolution does this emerges from Saint-Just's understanding and experience of revolution, and this is revolution's creation of a new template for morality with regard to political philosophy. Revolution, which, like one of its own objects of study, morality, also finds itself transformed by the constantly moving nature it takes on in its relationality as the process of integration of theory and actual, of ideal and real.

This relationality has a threefold theoretical base. One element of it is found in the relations between Saint-Just's theory and his actions, something which Saint-Just does not expressly discuss and yet something which is salient to many of those who study SaintJust. ${ }^{364}$ The second lies expressly within Saint-Just's theory of the social itself in its definition of the social as relational, ${ }^{365}$ which relationality is then connected to right. The third is the historical aspect of dialectics. ${ }^{366}$ Social right itself though is a historical moment of right, which concept is superseded by the relation of theory and action itself, which relation again is inexpress in the theory of Saint-Just and yet emerges from his total experience, such that this process which in Hegelian terms might be called Aufhebung, a simultaneous annulment and preservation, moves the center of right and morality to the more purely actual, locating its origin more squarely in the realm of movement that does not involve a theoretical substantive, such as a theory of social right. Saint-Just's discovery of social right is prescient, yet his action and practice is superior to this discovery, superior in the sense that the new 
locus of right and morality in the light of his experience, is more significantly non-theoretical, and derives from the theory-practice dialectic itself, which is integrity, and not from an idea posited in theory which takes the form of a traditional, discrete, theoretical substantive, such as does the concept of social right.

Theory then is not anchored in something nonhistorical but only in the relations which are defined by antipodes or moments, which antipodes themselves are shifting in a process of becoming. The moral component is found in the relation, in the relationship, and the definition of moral, and of right for that matter, and it is the correspondence between theory and action, or, more specifically, the attempt at this correspondence. Though the former notion of right in nature involves a constancy in nature that is not responsive to time, morality as it is found in the correspondence between theory and action must always be evolving, since it is based on temporal relations, and the concept of time which inevitably involves, and indeed makes no sense without, progression to what is in some sense new. There is no such thing as time without the idea of the new, and the locus of the new is in the idea of potentiality, of possibility, and technically nowhere else. Relatedly, the realm of the mind and of the idea is the realm of revolution, but its material component is really an evolution. The traditionally theoretical part of revolution in Saint-Just $i s$ a going back, albeit with a new consciousness, while the action of revolution is the place where the new is formed in its actuality. It is only in the realm of the idea that there is an area of validity for the notion that there is "nothing new under the sun", and thus only in the realm of the idea that movement must be a revolution, in the sense of movement back toward something that already has existed, and thus is not new. This knowledge opens the portal to thinking about the supersession of revolution and of its preliminary consideration in toto, as evolution. What this means is then that the full presence of the understanding of revolution itself is not 
yet achieved, but that even in its immanence one sees already its negation. History then, must be tied to morality in that the integrity of theory and action is, at least in part, a process of collective discernment of the social; not exactly of a zeitgest, but rather of something more immediately conscious, real, and active. The moral aspect of this consciousness is the attempt to achieve it, the attempt to create and maintain a correspondence between ideal and real or actual in both directions simultaneously. This integrity is both the goal and the practice of the revolution for Saint-Just, and in this sense the revolution is morality itself.

Expression of the Idea of the Civil Within the Area of Policy Revolution

The peaceful existence of Saint-Just's ideal society required for its formation a preliminary unity in its ideas. This unity in ideas would form the basis for the substantive content of the civil, or the governmental and regulative aspect of society, out of the social. The revolutionary government thus needed to consolidate a base for the erection of a future civil realm. Revolutionary government became this attempt and was then the temporary civil state. The temporality of the state of revolutionary government is attested to not only in Saint-Just specifically, but also in the decrees which he drew up, and in those drawn up by his colleagues, such as the decree of 14 Frimaire, Year $\Pi .^{367}$ This decree acted to consolidate the revolutionary base by, among other things, preventing federalism from taking hold by insisting on a structure of representative government which would support the unity necessary in a post-revolutionary social state. It removed all powers from the départments except for those over public works, local finances, and local state administered properties, reserving for the reorganized national government virtually all other powers. ${ }^{368}$ The ideal being a fusion of Spartan pastoral life and a modern Rousseauian general will 
society, a unity of understanding, direction, and desire, or will, had to be ensured an opportunity to live. But when would the government cease to be revolutionary, if ever? When would what was now theory become again practice, and practice come again to be an active rather than a theoretical practice? Saint-Just: "La République ne sera fondée que quand la volonté du souverain comprimera la minorité monarchique et régnera sur elle par droit de conquête. "369

The Convention declared the provisional government of France "révolutionnaire jusqu'à la paix" ${ }^{370}$ This, along with Saint-Just's statement quoted above, is perhaps a bit more specific but still indefinite, for how long could foreign enemies be said to be intriguing against France, and where is the line of war and peace drawn? The questions here had not yet become the later questions of revolutionary thought, such as whether or not revolution is possible in one country, and how much a revolutionary nation or political entity must isolate itself from counterrevolutionary states or entities. Since the French Revolution was not yet a communist revolution, the problem of market interference in a planned economy had not arisen, and yet one sees outlined the potential problem of isolation in an international system. Despite the fact though that the corrupt civil realm for Saint-Just is maintained if not established by the exterior relations of force, his words often express the possibility of a more universal unity of sentiment and action than his political philosophy, with its movement inward toward the intrastate social purity of the au-dedans as it were, would seem to predict:

Bientôt les nations éclairées feront le procès à la mémoire de ceux qui ont regné sur elles, et traîneront leurs ossements sur l'échafaud. L'Europe foulera aux pieds et la poussière et la mémoire des tyrans; alors tout gouvernement qui ne sera point fondé sur la justice sera abhorré... ${ }^{371}$

On the practical level internally, the revolutionary government was working with de facto civil institutions, which were either entirely the creation of this revolutionary 
government, or some amalgam of revolutionary governance and former institutional forms. The process of revolution for Saint-Just was, theoretically, the bringing about of institutions which would guarantee a society of original social relations. As conditions became more emergent however, the work of developing institutions was increasingly pushed in the direction of establishing civil institutions which would counteract and contravert developing obstacles to the establishment of these very institutions. The most primary of these obstacles was the threat of the dissolution of the revolutionary government itself. Thus, institutional foundation was, for Saint-Just, pushed in the direction of the ad hoc, in order to maintain the revolutionary government which would be the guarantor of stable institutions which would maintain natural social relations once contraversion of the revolutionary government had ceased. The future cessation of revolutionary government would be the acknowledgement that social institutions had been reestablished. The urgency of the need for institutions on both levels was crescendoing with the passage of time. Saint-Just attempted desperately to maintain a linearity with regard to the relationship of theory and practice, even when the necessary institutions had become secondary ones, only necessary to purify and retain the revolutionary character of the government:

...les institutions qui seront incessament rédigées présenteront les moyens que le gouvernement, sans rien perdre de son ressort révolutionnaire, ne puisse tendre à l'arbitraire, favoriser l'ambition, et opprimer ou usurper la representation nationale ${ }^{372}$

Exigency overtook, however. Saint-Just never got to these words, never got to speak them, since they were part of his last, mostly undelivered speech to the Convention.

Saint-Just is, in many respects, attempting to avoid a theory of revolution per se, and thus keeps theory in the realm of the normative, when the normative is distinguished from the revolutionary. And yet it seems that a theory of revolution comes out backwards in Saint-Just, 
as it were, as a theory comprised of revolutionary actions that inevitably call out for consideration as substantive elements of a theory of revolution, even as they retain the cast of the procedural. The force of circumstance has pushed Saint-Just to, for example, punitive measures against those who stand in the way of the reestablishment of natural social relations. These punitive measures have their own civil institutions, such as the Revolutionary Tribunal, its methods and practices. Do the civil institutions that Saint-Just is drawing up and attempting to present become affected by exigency; that is, do they become affected by conditions that would not apply in a state of harmonious social relations? More specifically, can civil institutions that serve as the guarantee of these natural social relations in a peaceful, established, and harmonious society be the same civil institutions that fend off attacks to the revolutionary government and which try to address the dangers to its maintenance, whether that maintenance be "jusqu' a la paix" or until proper social relations retake their place as government? To answer that they can indeed be the same seems to answer in keeping with Saint-Just's theoretical position, which seems to want to deny any difference. The radicalization of equality and democracy that Saint-Just's ideas and actions serve is then that which comprises the revolutionary character of the entire spectrum of theory and action which is his political experience. The universal example or idea of the French Revolution as the promise of the possibility of rapid establishment of equality and radical democracy remains the locus of the revolutionary for Saint-Just in its substantive aspect, even if it delimited a realm of procedure which was instructive and exemplary for later revolutions or for theories of revolution. Later revolutions such as the Russian Revolution certainly looked to the French Revolution for instruction and inspiration, but the Russian Revolution changed the content of revolution in a direction which made for the possibility of the idea of permanent revolution, which in a literal sense means that a practical, static realm of normalcy in a society, insofar as such a state can be contrasted to a revolutionary state, diminishes in 
scope and conceptual importance and is replaced by a stasis that is based on change, that is always revolutionary. ${ }^{373}$ In the specific working out of the theory of permanent revolution in the work of Leon Trotsky, ${ }^{374}$ the forces of stasis can be compared to the forces of bourgeois social democracy, and in this sense Saint-Just's ideas about revolution per se are again left open to accusations of being or containing elements of a bourgeois apologetics, and the entire content and idea of a static civil state of harmony guaranteed by institutions can then be seen as evidence of the residuum of bourgeois thought in its respect for the idea of a status quo, or of stasis even in the abstract, even if Saint-Just's basing the civil society on the commerce of the satisfaction of basic needs while placing equalizing limits on this commerce is, in this more concrete aspect, revolutionary.

Expression of the Idea of the Political Within the Area of Policy Revolution

The reality of foreign plots against the revolutionary government was something that Saint-Just's speeches, reports, and philosophical writings attested to regularly. ${ }^{375}$ This reality stood in the way of ideal post-revolutionary government whether these plots resulted in directives or actions or not, and the government of the Revolution had of necessity to be a government of defensive maneuvers, the maneuvers of a political (revolutionary) exigency. Saint-Just frequently contrasts the way things should be with the way things are now, the ought with the is, the devoir with the actuel, which contrast is always in some sense a comparison in time. After describing the various counterrevolutionary elements at work 
against the government in his Rapport sur les factions de l'étranger, Saint-Just goes on to contrast these with the ideal, the revolutionary government of the people, which, even in its incipiency, has been slipping away - thus his words attest to the idea that actuality has been forced back toward a pseudoactual, or theoretical existence with relation to time:

Les sociétés populaires étaient autrefois des temples de l'égalité. Les citoyens et les législateurs y venaient méditer la perte de la tyrannie, la chute des rois, les moyens de fonder la liberté. Dans les sociétés populaires, on voyait le people, uni à ses représentants, les éclairer et les juger. Mais depuis que les sociétés populaires se sont remplies d'êtres artificieux, qui viennent briguer à grands cris leur élévation à la législature, au ministère, au généralat, depuis qu' il y a dans les sociétés trop de fonctionnaires, trop peu de citoyens, le peuple y est nul. ${ }^{376}$

and later, "la hierarchie du gouvernement étant renversée, aucune idée, aucun principe n'est à sa place.",377

In looking at Saint-Just's experience, we can say that, in the process of actualization of social ideals, the displacement of practice back into the theoretical and to incipiency is a function of the political, or, in practical terms, of the counterrevolution. In keeping with the definition of revolution as inherently radical, and also with the idea of revolution as inherently progressive, we can say that the personnel of the Counterrevolution was comprised mostly of conservatives, and in this designation there is an inherent idea of resistance to the progression that the revolution involves with regard to equality. In revolutionary terms, these 'conservatives' would include all of those who were dedicated to the maintenance of inequality and to the regime of relations of force, with these relations' attendant social products, such as deception and fear. Other elements of the Counterrevolution were those who could be described as not having a political base or tendency, or any real political convictions, that is, the effectively indifferent. Among these 
would be the aventuriers and those wealthy persons and aristocrats who sympathized in theory with some elements of radical and revolutionary thought. ${ }^{378}$ A third element of the Counterrevolution was those persons not of the upper classes who supported the Revolution, but who had let fear overtake their beliefs and zeal for justice. Among these were all sorts of persons whose courage had failed them, including those given the Robespierrist label 'indulgents' which, as a substantive, described those so-called revolutionaries who wanted to end or diminish punishment by the Revolutionary Tribunal. These were largely the partisans of Georges Danton and Camille Desmoulins, who were seen as indulging the forces of moderation out of fear, and thus giving preference to reform rather than revolution. Many persons of course fit into more than one of these categories, as do for example the opportunists, some of whom were dedicated conservatives for whom Machiavellian opportunism and the maintenance of fortune and patronage were considered good and justified or justifiable, while some others were not persons of consideration and reflection, but merely persons living for immediate advantage without a foundation, and temporizing to that end. In Saint-Justian theory, all of the above are amalgamated as, one might say, victims of the relations of force, the relations of the political, and the political in this respect is then coterminous with counterrevolution in its conceptual terrain. The counterrevolution is thus the actualized political, and revolution in its actuality can be defined negatively, that is, in distinction to the forces arrayed against it.

Action, in a revolutionary lens, is the actualization of radical ideas. With this formulation, we can understand Saint-Just's insistence that the indifferent had to be punished in addition to those who were decidedly counterrevolutionary. ${ }^{379}$ The end of the revolution is the unity of theory and practice. Since practice though, is, as it were, held in check by the relations of the political, 'politics' occurs, and exists in its revolutionary form and from the 
revolutionary perspective, as the attempt to bring about this unity.

If one desires then, to delineate revolutionary 'politics' using Saint-Just's full experience as informative, one is faced with the difficulty of the traditional terminology of the subject. If we can place Saint-Just in a lineage of the emergence of the social as the subject matter of political science and political philosophy and draw from Saint-Just, the social becomes partially defined negatively with relation to the political, on the level of theory as that which is free from the relations of force, and by extension, freedom from a focus on power as definitive for political science and political philosophy, and on the level of action, as action in a radical and progressive lineage. Thus, revolution's conceptual terrain is of a particular character both in terms of theory and of action, and revolution affects "political" thought insofar as it accepts and rejects a particular ground for the future of thought that concerns human beings in society. If we seek to continue to delimit such a reoriented base or focus of political thought, we can make use of Saint-Just's work with regard to the political as, ironically, that against which the future content or subject matter of political science and political philosophy are defined. 


\section{Conclusion}

The relationship of theory and action in the political life of Saint-Just is necessarily an examination of this relationship in a context of revolution, and thus such an examination would portend the possibility that one could draw conclusions as much about revolution as one does about the relationships between theory and action more generally. Since revolution is a real and relevant aspect of all societies, it cannot be conceptually separated from a full examination of these, and so knowledge of relationships between theory and action can then be examined fully only by examining the relationship of revolutionary thought and action to thought and action in general. Thus, of necessity, this work has attempted to develop a partial basis for the further development of an understanding of revolution itself as a category, as a prerequisite or concomitance to any evaluation of the relationships between theory and action in their fuller relevance and breadth. The French Revolution, once established as a historical event, thenceforth disallowed examination of societies without an understanding of these as either founded on revolution, proto-revolutionary, prerevolutionary or as simply existing between revolutions, or interrevolutionary.

Where though, does revolution stand as a category? How, for example, does revolution stand in relation to the types of government frequently treated in traditional political philosophy, types such as monarchy, aristocracy, and mixed regimes, such as that of the constitutional monarchy? The dynamism of revolution with regard to time creates a conceptual dissonance from these categories of political philosophy. Revolution can be, in some sense, permanent (e.g. constant revolutionary measures designed to maintain the dictatorship of the proletariat), or temporary (e.g. when it is a radical purification and 
reassertion of the proper origins of the social; when it is a dialectical correction to historically outmoded and unconscious modes or modules of governance). This aspect of revolution is one that is not shared with the traditional categories of aristocracy and monarchy, for example. The dissonance is less in relation to the category of democracy, however, since revolutions by definition are radical and not reactionary, and always serve to further equality, the basis of democracy. Revolutions can take place within aristocracies and within democracies, and revolutionary governments and revolutionarily begotten democracies can be turned, at least temporarily, by the forces of reaction, back into aristocracies or, more probably, less democratic societies which are more aristocratic in some sense.

Revolution though, has an inherent active and progressive component in its second conceptual aspect, that is, in its aspect as event or process. Other traditional categories of governance have no element of progression in its most basic sense within them. Political theory then, when looked at in relation to despotism or aristocracy, would seem to be at most capable of being the art of justifying a relatively static political category, and thus quite limited in its purview. Since revolution is always understood as historically progressive, the possibilities for political theory expand. The historical expansion of the purview of political theory then takes place to the degree then that revolutions have been successful. Since revolutions, properly speaking, always bring about more democratic polities, or aim to do so, revolution becomes the possibility of the expansion of political theory through democracy.

Saint-Just prefigures and helps to fill out the groundwork of the social as a replacement for the political as the subject matter of political science. Saint-Just's view of force as 
inimical to the social, and naturally alien to it, anticipates some important later lines of political philosophy. In his desire to remove force from the commonwealth, Saint-Just prefigures later critiques of power which come from, for example, feminist theory. Catherine MacKinnon points out that authority is the male question, but not a question which women naturally ask. ${ }^{380}$ Questions about authority and about force are understood by Shulamith Firestone to be questions that arise from the psychology of power. The ultimate end of feminist revolution for Firestone is the end of the psychology of power. ${ }^{381}$ The sweeping away of force from the state, in which idea Saint-Just follows Rousseau's delegitimization of authority based in force, lays the ground for the transcendence of the questions of force, authority, and power as political questions. Can such questions survive in a denatured political - in the social realm as it is described by Saint-Just? The answer must be that they cannot. This answer though goes beyond Saint-Just's ideal state in practice in that its reality is revolutionary for the idea of the political. Thus, the theoretical grounding of the Revolution, retroactive as it is in its work of the reestablishment (re-volution to) the social, is also of the future, and of $e$-volution. The postrevolutionary polity would beget a social discourse in which authority, power, and force are not formative questions, as they are in the realm of the political. Thus, for example, the master-slave dialectic of Hegel becomes a corruption, that is it becomes an improper question insofar as it is seen as basic and essential. $^{382}$

The reestablishment of right is then, in the language of the traditional discourse of natural law from which Saint-Just's theory attempted to speak revolution, the reestablishment of a social discourse that is of the relations of love and affections. In such a discourse, the questions which formed the political, questions of power and authority and force, are foreign. 
The relation based philosophy of Saint-Just, by virtue of its being such, has already within it the portent of a spatio-temporal question which is relevant for dialectics and indeed for any guise in which the theory and action relationship presents itself. Saint-Just's presentation of essential relations as bipolar and antipodal (homme $<------->$ homme) is then a dialectical tendency, though, more broadly and perhaps more importantly, the underlying implication of essence as relational and thus necessarily occurring and existing as movement, opens up the doors to further development of modern motion-based templates for understanding the bases of political reality, following after Hobbes and Descartes. The imputation of a tripartite division between theory, practice and exigency allows for the opening up of perspective on models for political events and histories in their relation to thought as political ideals, and does so not merely in the tripartite division of historical events but also in the more complex sense of calling sequence into question in the mediated movement between the thought and the action in the context of revolution, which seems to establish an intermediary theoretical as an unrealized actual, even while this unrealized action, this practice, or practical, becomes more purely theoretical even while it is importantly distinct from it.

This complexity of time and sequence with regard to political theory and action also has a moral implication in the increased complexity and reevaluation it necessitates with regard to integrity, with integrity defined as the moral aspect of the relationship between theory and action. While Robespierre in life and in death existed in the mind of many as 'the Incorruptible', Saint-Just did the difficult work of this incorruptibility in his ardent attempts to establish a theoretical base for the revolution, attempts which brought about, for him, the 
situation of a halted, stillborn realm of practice in its letter, even as its spirit retained some grip on consciousness. It is not that Saint-Just is the only political figure to experience some complexity in the unfolding of the actual in relation to the ideal, but only that his political experience, taking the phrase in the largest sense, is exemplary for having encompassed the full range of roles of the political person (statesman, legislator, executive, military figure, political theorist, founder, follower, revolutionary), but also that the last of these, the role of revolutionary, seems to beseech us to find within it some knowledge about revolution per se, especially since the existing knowledge on revolution from within political science is seems to be unsatisfactory and contradictory and seems to point up the shortcomings of analysis ${ }^{383}$ when observing something which is dynamic and new, and yet also something which might have an important connection to the dialectical yet hypothetical telos of later historically connected political philosophies, all of which reacted to the French Revolution.

The particular way that revolution as it is understood herein however, puts it in a certain relation to thought as an aspect of theory, and this is revolution's aspect as the realization of the type of thought called consciousness, both in its sense as historicaldialectical awareness and in its sense as concerned social awareness. Revolutionary action is the result of the increase in the type of thought called consciousness, and it acts in bidirectional combination with ideas which have material origins, to bring about change. Thus, revolution, in addition to being brought about by consciousness, validates and reifies the type of thought called consciousness, in particular what is called 'social consciousness'. Such a consciousness unites philosopher and non-philosopher, and this connection involves interaction that is mutually influential, and social ties produce actions which contextualize thought within social consciousness's narrative, which is history.

If one wants to alter the course of history, one is faced with the question of the value of 
historical alterations in relation to individual mortality. Insofar as there is a possibility of significant change in one's lifetime, revolution is the way in which this change is brought about when the desire for change is a desire for greater equality and when this desire is not based in fear, as reactionary changes are. Revolution as radicality's mode of action has a speed aspect, and in this sense a temporal aspect. Revolution as a mode of action speeds up reorientation of societies in relation to reform. Thus, thought, insofar as it remains connected to the realities of the lives of other persons in a society, is more quickly reoriented in terms of what the people demand that it address; even idealistic speculation and reverie now have new origins in terms of the content of their imagery and the perceived limits of possibility. The fact of the possibility of individual mortality seems to act as catalyst for revolution also in the sense that real change in material conditions of life is not always for posterity. This mortality aspect is present also in reactionary change though, and what accounts for the difference in revolution? The difference in revolution is its goal and premise, in a radical lineage, of a primary concern for the development and perpetuation of democracy and of equality as essential to justice. In Saint-Just's theory, the legislator, as the one who discerns justice as social right, is the new political philosopher. Discernment of the type required by the legislator-philosopher in Saint-Just has a necessary historical component in that the deviation of social relations from the state of natural affections of persons of the same territory and same "species" is an historical process of distancing and usurpation. Such discernment also then must have consciousness as a component, both in the historical sense and in the sense of awareness of the essence of a society's relations, no matter what degree these are covered over or altered by the usurpation of the social by the relations of power. The legislatorphilosopher is necessarily then highly conscious with regard to both history and her or his own society and its essential relations. The social as the level of focus of the legislatorphilosopher places nature in a supportive role in the process of discernment, though nature is 
not the theoretical focus of such a legislator. Similarly, though the political establishes the social and the legislator-philosopher plays a negating role insofar as she or he must also discern the relations of the political and separate these from the social, undoing the misappropriation of relations of harmony by relations of force, the positive and primary goal of the legislator-philosopher is the establishment and maintenance of the social realm, and his or her duty would consist in such things as the fortification of friendship and the establishment of guarantees against exploitation. Such activity is the result of the combination of the tieing of political philosophy to consciousness and to the social, and the new political philosopher is thus a creation of social consciousness. This view of political philosophy has within it then necessarily an imperative for social action. The politicalphilosopher as Saint-Justian legislator is necessarily a person of social thought and social action, and in fact a walking embodiment of their unity. The conception of the legislator as political-philosopher within this understanding incorporates a theory of the morality of political philosophers, and thus morality can no longer merely be an outward focus and subject matter of political philosophy, but now also necessarily contains an imperative for the activity of political philosophy itself.

If one adopts then a Hegelian-Marxian historical dialectic as template for consciousness, there is still within that dialectic both the general idea of unforeseen transcendence, and along with this the idea of the political philosopher as paranoiac of the world historical consciousness, and also the more specific idea of the transcendence of history itself, which idea falls right into the arms of Nietzsche's idea that one can pick and choose from history in the service of being an 'artist of life'; this idea contains as a premise though, that this very picking and choosing is not historically determined. 
With regard to further development of Hegelian dialectics, we can see Habermas's description of the role of social theory as comparable to Saint-Just's reasoning with regard to social relations and thus again the historical prescience of Saint-Just:

Theories which in their structure can serve the clarification of practical questions....can only be translated into processes of enlightenment which are rich in political consequences when the institutional preconditions for practical discourse among the general public are fulfilled. ${ }^{384}$

The social relations of a Saint-Justian society are produced in communication and maintained through social institutions. In relation to Habermas though, Saint-Just's work is not concerned with the elaboration of a theory of communication in particular, but rather with communication's natural occurrence and its maintenance.

Saint-Just's prescience with regard to social theory and practice is in his actual total experience. Thus, again, the predisposition for the fusion of theory and action in Saint-Just is only present, or at least finds it origin, in the actual, in Saint-Just's actual, lived experience in its totality, and is not consciously present in his theory alone, and this presence and its consideration are retrospectively understood through the narrative of a developed, praxisoriented theoretical paradigm.

Habermas's 'practical questions', in their characterization as questions posed with a view to the acceptance or rejection of norms for action, actually find development in SaintJust in the realm of revolutionary action. The question of the development of theory as a foundation or apologetics for revolutionary action actually potentially places Saint-Just's work more radically in the realm of action than does the idea of praxis, or fusion of theory and practice. The origin of goals or values in nature, or in natural social relations, keeps Saint-Just's theory partly within the tradition of natural law then, while his action seems to crescendo under revolutionary circumstances to a fusion of theory and practice, and then to a 
reversal of the order from theory $\rightarrow$ practice to practice $\rightarrow$ theory.

In his formulation of the questions that comprise theory, Habermas first excises the purely contemplative from consideration, which Saint-Just has done as well. The political experience of Saint-Just then moves through the technical questions of theory to the fusion of theory and practice in the practical, and yet more radically so, since his experience at least presents to us the possibility of revolutionary action as the precedent for theory. The more exigent the circumstance, the more action asserts itself as prior.

\section{Diagram 5}

The Circularity of Theory, Practice, and Exigency Expressed as Linear

\begin{tabular}{|l|l|l|}
\hline $\begin{array}{l}\text { theory (both antecedent and } \\
\text { subsequent) }\end{array}$ & $\begin{array}{l}\text { practice (the civil state) } \\
\text { (homeostasis) }\end{array}$ & action (revolution) (ground for \\
theory)
\end{tabular}

But does the realm of pure action, with regard to the political actor, really exist? Can even emergency action or even action of the moment be purely without a theoretical foundation of some sort? The answer, I think, is that neither purity of theory nor purity of action are real, and exist on a continuum, but that what is relevant for a sociopolitical epistemology is this tendency, or movement between theory and action as narrative elements of political understanding. What is radical is the portent of revolutionary action's existence as the progenitor of theory - its potential primary location in a temporal progression or reciprocal relationship of theory and actual. 
In the action aspect of Saint-Just's politics, there is the portent of an action-initiated political philosophy which might provide one base for the further development of modern thought, laying aside the Nietzschean problematization of the 'mind', and the necessary problematization of philosophy or theory as its necessary concomitance, with 'mind' as the

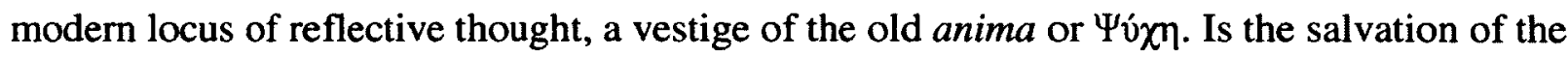
province of reflective thought, of mind itself as creative thought under free will, ironically the movement of the connotation of mind to a focal point mediated in action and not in what we have previously understood as reflective thought - from a centeredness on syllogism to an inductive process? Or, if not, can we, as persons who have valued political theory, do without free will and creativity? Is political philosophy now the great actualizer?

If we take seriously the idea that class is determinative of thought and action, what then for philosophy? The disparagement of philosophy or the indication that it is finished has become, again, as good as a hallmark of theorists, ${ }^{385}$ and as such is hardly a reason for considering a work, or work, that speaks against philosophy as nonphilosophical. Saint-Just, even as he disparages philosophy, attempts to do political philosophy and further to actualize it. 
I have seen this work as an exploration, and this is partly because the idea of stating instead of asking questions comes, for me, only with difficulty. The idea of taking a thinker' or actor's "argument" and critiquing it has also seemed to me not to do enough justice to the honest attempts of persons to understand how to live, and yet I have great respect for it as an academic approach to knowledge. As with many explorations of large questions that seem to fall within the purview of the political and the philosophical, I have found that each answer to a question leads to further questions, and that one wants to have known at the beginning what one only knows at the end of an exploration, that is, one wishes to take one's new (or recalled?) knowledge and new questions, one's deepened or strenghtened knowledge, and make of it premises to further develop ideas. At this point I find it hard to see this humbling progression of knowledge through exploration in a hopeful way, but perhaps that is only because one's disposition and emotional interaction with knowledge in its various modes and stages of production is itself a part of the process of knowledge. 
$\stackrel{+}{N}$

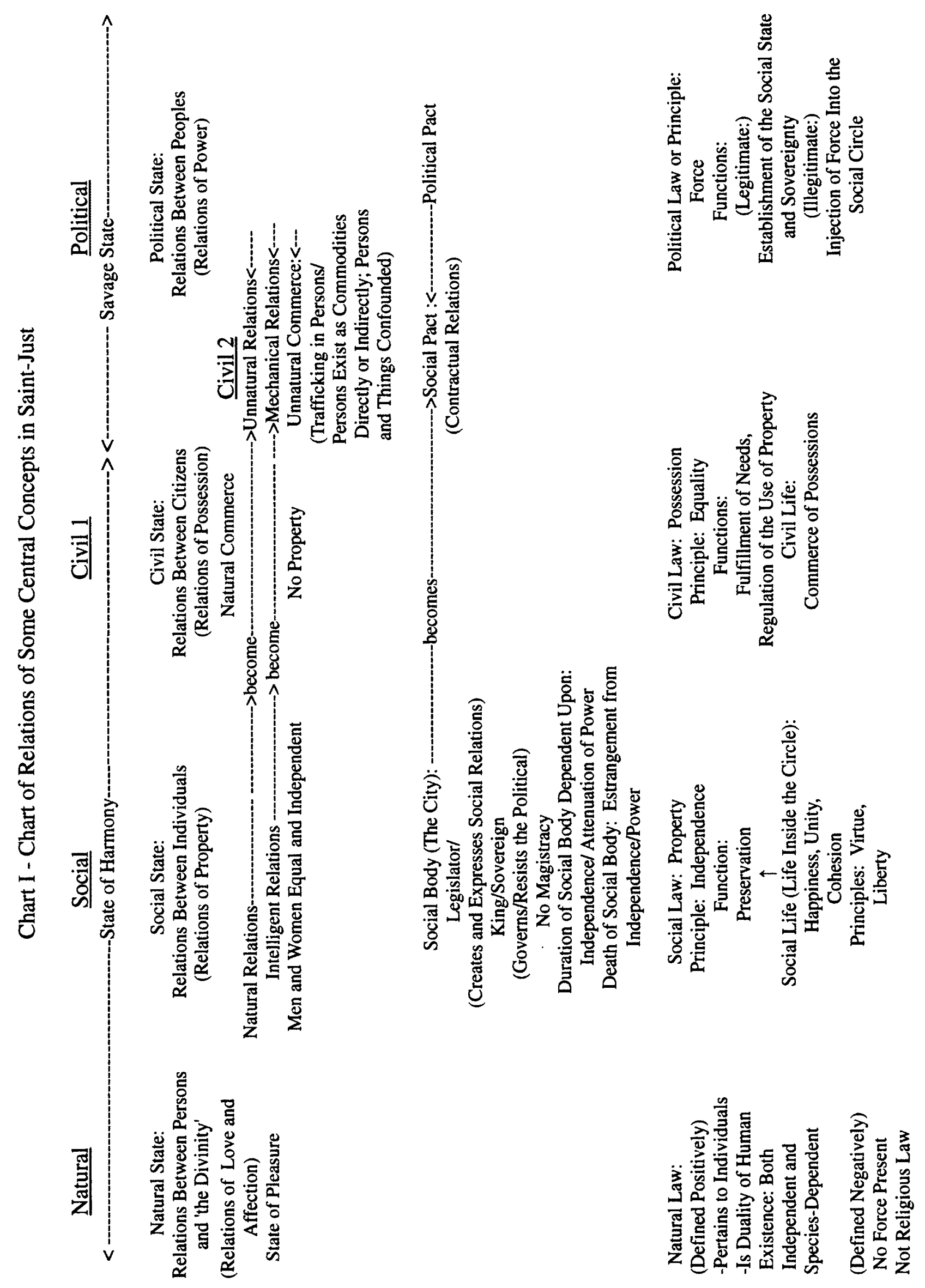




\section{BIBLIOGRAPHY}

Abensour, Miguel. Democracy Against the State. Marx and the Machiavellian Moment. Trans. Max Blechman and Martin Breaugh. Malden, MA: Polity Press, 2011.

Abensour, Miguel. "La Philosophie Politique De Saint-Just." Annales Historiques de la Révolution Française. No. 183, Jan.-Mar. 1966 pp. 1-32 and No. 184 Avril - Juin pp. 341358.

Archives Parlementaires de 1787 à 1860 . Various Dates and Publishers.

Arendt, Hannah. On Revolution. New York: Viking Press, 1966.

Arendt, Hannah. The Human Condition. Chicago: University of Chicago Press, 1958.

Arendt, Hannah. The Promise of Politics. Random House Digital, Inc. Jan. 16, 2009.

Aulard, Alfonse. Mémoires de Chaumette sur la Révolution de 10 Août 1792. Paris: Société de l'Histoire de la Révolution Française, 1893.

Aulard, Alfonse. La Société des Jacobins. Recueil de documents pour l'histoire du club des Jacobins de Paris. Paris: Librairie Léopold Cerf, 1895.

Aulard, Alfonse. Recueil des Actes Du Comité de Salut Public avec la correspondance officielle des représentants en mission et le registre du Conseil exécutif provisoire. Paris: Imprimérie Nationale, 1889-1910.

Avakian, Bob. Communism: The Beginning of a New Stage. Chicago: RCP Publications, 2008.

Avakian, Bob. Democracy: Can't We Do Better Than That? Chicago: Banner Press, 1986.

Baker, Keith Michael. Condorcet. From Natural Philosophy to Social Mathematics. Chicago: University of Chicago Press, 1975.

Baker, Keith Michael. Inventing the French Revolution. Cambrige, U.K.: Cambridge University Press, 1990.

Baker, Keith Michael. "Transformations of Classical Republicanism in Eighteenth Century France." Journal of Modern History, Vol. 73 No. 1. (March 2001): pp. 32-53.

Ball, Terence, ed. Political Theory and Praxis. Minneapolis: University of Minnesota Press, 1977.

Bapst, G. "Inventaire des bibliothèques de quatre condamnés". La Révolution Française. 21 1891, pp. 532-536. 
Barthes, Roland. Mythologies. Trans. Annette Lavers. New York: Farrar, Straus, \& Giroux, 1972 ,

Beesly, A.H. The Gracchi, Marius, and Sulla. New York: Charles Scribner's Sons, 1896.

Billaud-Varenne, Jacques-Nicolas. Principes Régénérateurs du Système Social. Paris: Publications de la Sorbonne, 1992.

Bossuet, Jacques Bénigne. Discours sur l'histoire universelle. Paris: Librairie de Firmin Didot Frères, 1845.

Braconnier, Martine. Couthon. Yssingeaux, France: Éditions du Roure, 1996.

Centore- Bineau, Denise. Saint-Just. Paris: Payot, 1936.

Cobban, Alfred. Aspects of the French Revolution. New York: George Braziller, 1968.

Cole, G.D.H. Essays in Social Theory. London: MacMillan, 1950.

Colletti, Lucio. From Rousseau to Lenin. New York: Monthly Review Press, 1972

Dayan- Herzbrun, Sonia, Anne Kupiec, and Numa Merard. 'L'homme est un animal utopique. Entretien avec Miguel Abensour', Mouvements Vol. 3, No. 45-46, (2006): pp. 71-86 (accessed online)

Dommanget, Maurice. Saint-Just. Paris: Éditions du Cercle, 1971.

Dusssert, Gilles. Vadier. Le Grand Inquisiteur. Paris: Imprimérie Nationale, 1989.

Edwards, Lyford. The Natural History of Revolution. Chicago: University of Chicago Press, 1927.

Elton, Geoffrey. The Revolutionary Idea in France. New York: Howard Fertig, 1969.

Engels, Frederick. Socialism: Utopian and Scientific. [Chicago: Charles H. Kerr \& Co., 1907.] Marxists.org

Fehér, Ferenc, ed. The French Revolution and the Birth of Modernity. Berkeley, CA: University of California Press, 1990.

Feuerbach, Ludwig. The Essence of Christianity. London: Truibner \& Co., 1881.

Fortunet, François. 'L'Amitié et le droit selon Saint-Just'. Annales historiques de la Révolution Française No. 248, 1982, pp. 181-195.

Franklin, Julia. Selections from the Works of Fourier. London: Swan, Sonnenschein \& Co. Lim., 1901. 
Freeden, Michael. Ideologies and Political Theory: A Conceptual Approach. Oxford, U.K.: Oxford University Press, 1996.

Freeden, Michael. Liberal Languages: Ideological Imaginations and Twentieth-Century Progressive Thought. Princeton, N.J.: Princeton University Press, 2005.

Gignoux, C.-J. Saint-Just. Paris: La Table Ronde, 1947.

Godechot, Jacques. La Contre-Révolution. Doctrine et Action. 1789-1804. Paris: Presses Universitaires de France, 1961.

Godechot, Jacques. Les Institutions De La France sous la révolution et l'empire. Paris: Presses Universitaires de France, 1951.

Greenlaw, Ralph W. The Social Origins of the French Revolution. Lexington, MA: D.C. Heath \& Co., 1975.

Gurvitch, Georges. L'idée du droit social. Paris: Librairie du Receuil Sirey, 1931. Microfilm.

Habermas, Jürgen. Theory and Practice. Trans. John Viertel. Boston: Beacon Press, 1973.

Hagopian, Mark N. The Phenomenon of Revolution. New York: Harper \& Row, 1974.

Hale, Charles, ed. Engaging Contradictions. Theory, Politics, and Methods of Activist Scholarship. Berkeley, CA: University of California Press, 2008.

Hamel, Ernest. Histoire de Saint-Just. Brussels: Meline, Cerns et Cie, 1860.

Hampson, Norman. Saint-Just. Oxford, U.K.: Basil Blackwell, Ltd., 1991.

Hampson, Norman. The Enlightenment. Harmondsworth, U.K.: Penguin, 1986.

Hampson, Norman. Will and Circumstance. Norman, Oklahoma: University of Oklahoma Press, 1983.

Hibben, John Grier. Inductive Logic. New York: Charles Scribner's Sons, 1899.

Hill, Christopher. The English Revolution, 1640. London: Lawrence \& Wishart, 1940. Electronic transcription by Andy Blunden, 2002.

Hill, Christopher. The Intellectual Origins of the English Revolution. Oxford, U.K.: Clarendon Press, 1980.

Hobouyan, Sylvie "Saint-Just vu à travers la graphologie", Actes du colloque Grandes Figures de la Révolution française en Picardie, Association pour la sauvegarde de la maison de SaintJust, 1990. 
Hoernlé, R.F. Alfred. Idealism as a Philosophical Doctrine. New York: George H. Doran Company, [1924?].

Howard, Dick. The Marxian Legacy. Minneapolis: University of Minnesota Press, 1988.

L'Institut d'Histoire de la Révolution Française du Centre National De La Recherche Scientifique. Procès-Verbaux des séances de la Convention nationale. Table Analytique. 1959-1963.

Jannet, Claudio. Les Institutions Sociales et le Droit Civil à Sparte. Paris: A. Durand et Pedone-Lauriel, 1880.

Jardin, André. Tocqueville. A Biography. Trans. Lydia Davis with Robert Hemenway. New York: Farrar Straus Giroux, 1988.

Kaplan, Lawrence and Carol Kaplan, ed. Revolutions. A Comparative Study. New York: Random House, 1973.

Kermina, Françoise. Saint-Just. La Révolution aux mains d'un jeune homme. Librairie Académique Perrin, 1982.

Kojève, Alexandre. La notion de l'autorité. France: Gallimard, 2004.

Kuehn, Manfred. Kant. Cambridge, U.K.: Cambridge University Press, 2001.

Laclau, Ernesto. Politics and Ideology in Marxist Theory. London: NLB, 1977.

Ladret, Albert. Saint-Just et les vicissitudes de la virtue. Lyon, France: Presses Universitaires de Lyon, 1989.

Lazarus, Sylvain. Anthropologie du Nom. Paris: Éditions du Seuil, 1996.

Le Moniteur Universel (Gazette Nationale) Paris: H. Agasse, 1792-1795.

Lefebvre, Georges. Études sur la Révolution Française. Paris: Presses Universitaires de France, 1954.

Linton, Marisa. 'The Man of Virtue: The Role of Antiquity in the Political Trajectory of L.A. Saint-Just. French History Vol. 24, No. 3., 2010

Mably, Gabriel Bonnot, Abbé de, Doutes Proposés aux Philosophes Économistes sur L'Ordre Naturel et Essentiel des Sociétés Politiques. La Haye: Publisher Unknown, 1768. Microfilm.

Mably, Gabriel Bonnot, Abbé de, Collection Complète des Euvres de Mably. Tôme Dixième. Paris: Charles Desbrière, Year III (1794-1795).

Manning, Brian. The Far Left in the English Revolution. London: Bookmarks, 1999. 
Marcuse, Herbert. One-Dimensional Man. Boston: Beacon Press, 1964.

Marx, Karl. The Poverty of Philosophy. Chicago: Charles Kerr \& Co., 1920.

Mathiez, Albert. Contributions à l'histoire religieuse de la révolution française. Paris: Félix Alcan, 1907.

Mathiez, Albert. La Conspiration de l'étranger. Paris: Librarie Armand Colin, 1918. Digital Version 2009.

Mathiez, Albert. La Question Sociale Pendant la Révolution Française. Paris: Édouard Cornély et Cie, 1905.

Mathiez, Albert. La Révolution Française. Saint-Amand, France: Denoël, 1985.

Mathiez, Albert. Le Bolchévisme et le Jacobinisme. Paris: Librairie du Parti Socialiste et de l'Humanité, 1920.

Michell, H. Sparta. Cambridge, U.K.: Cambridge University Press, 1964.

Mingst, Karen A., and Jack Snyder, eds. Essential Readings in World Politics. New York: Norton, 2004.

Montesquieu, Charles Louis de Secondat, Baron de. The Spirit of the Laws. Translated, Edited by Anne Cohler, Basia Miller, Anne Stone. Cambridge, U.K.: Cambridge University Press, 1989.

Morelly, Étienne Gabriel. Code de la Nature. Paris: Paul Masgana, 1841.

Murray, James Croall. Revolutionary Process and Outcome: Theory and the Mexican Revolution. Ann Arbor, Michigan: University Microfilms International, 1986. Print Facsimile of Dissertation from Microform.

Nichols, James H., Jr. 'L'enseignement de Kojève sur l'autorité.' Trans. Isabelle Hauser. Commentaire, No. 128, Hiver 2009-2010, pp. 880-891 (Reproduction).

Ollivier, Albert. Saint-Just et la Force des Choses. Paris: Gallimard, 1954.

Pippin, Robert B. Idealism as Modernism. New York: Cambridge University Press, 1997.

Philonenko, Alexis. Essai sur la philosophie de la guerre. Mayenne, Fance: J. Vrin, 2003.

Poulantzas, Nicolas. Political Power and Social Classes. Timothy O'Hagan, trans. London: NLB and Sheed and Ward, 1973.

Quennedey, Anne. "Note philologique sur le manuscrit de Saint-Just faussement intitule 'De La Nature'". Annales Historiques de la Révolution Française 351 Janvier-Mars 2008, pp. 121- 
149.

Rees, John, ed. Essays on Historical Materialism. London: Bookmarks, 1988.

Robespierre, Maximilien. Euvres. Paris: Presses Universitaires de France, 1967.

Rousseau, Jean-Jacques. Discours sur l'origine et les fondements de l'linégalité parmi les hommes. Henri- François Muller and René E.G. Vaillant, eds. New York: Oxford University Press, 1922.

Rousseau, Jean-Jacques. Discours sur l'origine et les fondements de l'inégalité parmi les hommes. Paris: Garnier-Flammarion, 1971.

Rousseau, Jean-Jacques. Extraits de J.-J. Rousseau. L. Brunel, ed. Paris: Hachette, 1909.

Rousseau, Jean-Jacques. The Basic Political Writings. Trans., ed. Donald A Cress.

Indianapolis: Hackett, 1987.

Rousseau, Jean-Jacques. The Discourses and Other Early Political Writings. Ed. Victor Gourevitch. Cambridge, U.K.: Cambridge University Press, 2003.

Rousseau, Jean-Jacques. The First and Second Discourses. Roger D. Masters, ed. New York: St. Martin's Press, 1964.

Rousseau, Jean-Jacques. The Social Contract and Discourse on the Arts and Sciences. Trans. G.D.H. Cole, London: E.P. Dutton \& Co., 1920.

Saint-Just, Louis Antoine Léon de. Discours et Rapports. Ed. Albert Soboul. Paris: Éditions Sociales, 1957.

Saint-Just, Louis Antoine Léon de. Esprit de la Révolution et de la Constitution de France. Paris: Beuvin, 1791.

Saint-Just, Louis Antoine Léon de. L'Esprit de la Révolution. Ed. Michel Vovelle. Paris: Éditions 10/18, 2003.

Saint-Just, Louis Antoine Léon de. Fragmens sur les Institutions Républicaines. Ed. Charles Nodier. Paris: Techener, 1831.

Saint-Just, Louis Antoine Léon de. Fragments sur les Institutions Républicaines. Paris: Éditions 10/18, 2003. Online Facsimile.

Saint-Just, Louis Antoine Léon de. Euvres Complètes. Ed. Charles Vellay. Paris: Librairie Charpentier et Fasquelle, 1908.

Saint-Just, Louis Antoine Léon de. CEuvres Complètes. Ed. Michèle Duval. Paris: Éditions Ivrea, 1989. 
Saint-Just, Louis Antoine Léon de. CEuvres Complètes. Eds. Miguel Abensour and Anne Kupiec France: Gallimard, 2004.

Saint-Just, Louis Antoine Léon de. Euvres de Saint-Just. Ed. Jean Gratien. Éditions de la cité universelle, 1946.

Saint-Just, Louis Antoine Léon de. Pages Choisies. Jean Cassou, ed. Les éditions du point de jour, 1947.

Saint-Just, Louis Antoine Léon de. Saint-Just: théoricien de la Révolution. Ed. Charles Vellay. Monaco: Jaspard, 1946.

Saint-Just, Louis Antoine Léon de. Théorie Politique. Ed. Alain Liénard. Paris: Éditions du Seuil, 1976

Saint-Just, Louis Antoine Léon de et al. Papiers inédits trouvés chez Robespierre, Saint-Just, Payan, et cetera. Paris: Badouin Frères, 1828.

Sieyès, Emmanuel. Rapport Du Comité de Défense Générale, Pour Organiser Le Ministère De La Guerre. Paris: Imprimérie Nationale, 1793. Reprinted in Vol. 3 of Euvrres de Sieyès, Paris: EDHIS, 1989.

Skocpol, Theda. States and Social Revolutions. Cambridge, U.K.: Cambridge University Press, 1979.

Skyrms, Brian. Choice and Chance. An Introduction to Inductive Logic. Encino, California: Dickenson Publishing Company, 1975.

Slavin, Morris. The Left and the French Revolution. New Jersey: Humanities Press, 1995.

Soboul, Albert et al. Actes du Colloque Saint-Just. Paris: Société des Études Robespierristes, 1967.

Soboul, Albert. "Jean-Jacques Rousseau et le Jacobinisme." Studi Storici 1.4 (January-March 1963): 1-22.

Soboul, Albert. "Les Insitutions Républicaines de Saint-Just D'Après Les Manuscrits De La Bibliothèque Nationale." Annales Historiques De La Révolution Française No. 111 JuilletSeptembre 1948.

Soboul, Albert. "Un manuscrit inédit de Saint-Just" Annales Historiques de la Révolution Française No. 124 Octobre-Décembre 1951 321-359.

Taylor, Keith. The Political Ideas of the Utopian Socialists. London: Frank Cass and Company Ltd., 1982.

Tocqueville, Alexis de. The Old Regime and the French Revolution. Trans. John Bonner. Dover (2010). (Reprint of Harper \& Brothers edition of 1856) 
Thuillier, Guy. "Saint-Just et la cité usurpée par les fonctionnaires." La Revue Administrative. Volume 8. 1955, pp. 498-505.

Urban, Wilbur Marshall. Beyond Idealism and Realism. London: George Allen \& Unwin Ltd., 1949.

Vazquez, Adolfo Sanchez. The Philosophy of Praxis. Mike Gonzalez, trans. London: Merlin Press, 1977.

Vinot, Bernard. Saint-Just. Fayard, 1985.

Vovelle, Michel. Réligion et Révolution. La Déchristianisation de l'an II. Poitiers, France: Hachette, 1976.

Wolin, Sheldon. Tocqueville Between Two Worlds: The Making of a Political and Theoretical Life. Princeton, N.J.: Princeton University Press, 2001.

Wright, Johnson Kent. A Classical Republican in Eighteenth Century France. The Political Thought of Gabriel Bonnot de Mably. Stanford, California: Stanford University Press, 1997.

Xenophon. Polity of the Athenians and Lacedaemonians. Trans. H.G. Dakyns. Project Gutenberg, n.d. Electronic Edition. 


\section{Notes}

${ }^{1}$ Philonenko, 92. Philonenko is writing here specifically about Saint-Just. (The French 'politicien' has here the same patina of the pejorative as does one sense of 'politician' in English).

${ }^{2}$ See the Note on the Works of Saint-Just.

${ }^{3}$ The national legislative body of France originated in the Estates General, which set up the Constituent Assembly. The Constituent Assembly was succeeded in July 1789 by the National Legislative Assembly, which in turn was replaced by the National Convention in September 1792. Thus, during Saint-Just's campaign and at his election thereto the body was called the National Legislative Assembly, or simply the Legislative Assembly. His arrival in Paris as a national representative occurred three days before the official change of name of the national legislative body to the National Convention.

${ }^{4}$ The National Convention, one year later, retroactively declared a new republic and calendar to have begun September 22, 1792. Most historians begin dating events with the French Revolutionary Calendar only in and after September 1793. Herein I follow the nonstandard practice of dating all events after September 21,1792 using the new calendar, in keeping with the intentions of the Revolutionaries. This dating is further supported by the fact that the annual aspect of the calendar was declared in effect at the inception of the Convention in 1792 , with the other aspects of the calendar readied during the ensuing year and put into practice in September 1793, with the intention that these also be retroactive to September $21,1792$.

${ }^{5}$ See the Biography for the titles of these works and their placement chronologically.

${ }^{6}$ For some evidence and discussions of considerations of the ordering of Saint-Just's works, both in relation to one another and with regard to the content of each (these questions become interrelated), see Quennedy, Ollivier pp. 563-567, Soboul (1951) and also his discussion on pp. 42-45 of Saint-Just - Soboul (1957), Alain Liénard's notes on p. 138 and pp. 248-250 of Saint-Just - Liénard (1976) and note 4 on p. 2 of Abensour (1976).

${ }^{7}$ "Le travail de rangem[ent] est d'autant plus difficile que Saint-Just remettait souvent la main à la pâte en utilisant ses vieilles notes, ses «fonds de tiroir» pour les accommoder aux conditions du moment." Ollivier, 563. ${ }^{8}$ See for example Mathiez (1918), Chapter VIII, 'Un faux rapport de Saint-Just'.

9 'Theoria'. See note 226 below.

${ }^{10}$ In this work, 'revolution' is understood as both part of a radical lineage and as properly distinguished from reform. Radicalism is understood to be related to revolution in the same way as liberalism is related to reform. I propose to understand radicalism as not merely a term used to describe the degree or depth of a belief, argument, or philosophy, but rather as a tradition within political history, a tradition with a particular substance and a particular character. This substance or character of radicalism is one of progressivism with regard to democracy and a valuation of democracy which sees it as a goal or precondition, and of increasing sociopolitical consciousness historically and in individuals and societies, or the attempt at such or the belief in such. I understand revolutions to be, properly speaking, only the result of radical ideas, philosophies, and plans. Revolution is then the actualization of radical ideas. Since the very explorations of this work inspect the order of theory and action in an attempt to better understand political thought and experience, the relationship can be seen in reverse, with revolutions being also the source of radical ideas. With this view of the relationship between radicalism and revolution, many events that are referred to as revolutionary, events such as the "Iranian Revolution" of 1978 , would be seen as the opposite of revolutionary - as counterrevolutionary or reactionary. The understanding of revolution herein also contrasts it to reform, seeing reform as the types of actions which result from liberal ideas rather than from radical ones. In this understanding then, liberalism and radicalism are homologous on the level of ideas, while reform and revolution are so on the level of political action.

${ }^{11}$ Ball, 64.

${ }^{12}$ Ball, 66

${ }^{13}$ See Arendt's Human Condition for a description of these terms and their relationship, esp. p. 14

${ }^{14}$ Valerie Solanas's work is an example of feminist work that contains a totalizing critique of philosophy as male sexual pathology aggrandized into philosophical questions and problems. Henry Kariel's work is an example of the idea that the critical and postmodern turn of philosophy was both necessary and fatal to further movement. The many and various attempts to formalize and scientize the 'sciences of man' stand as attempts to end philosophy as it has been known.

${ }^{15}$ DDS, Book I , Chapter IV. Saint-Just - Abensour, 1051.

16" Quand j'observe à quoi tend nôtre inquiétude, je trouve que le repos des Indiens est la sagesse même." DDS, Book I, Chapter III. Saint-Just - Duval, 926.

17"J'ose prédire que l'homme doit tôt ou tard fouler aux pieds ses idoles. Quel peuple n'a pas fini par mépriser ses lois et ses dieux; pourquoi cela? c'est que corrompu par eux et éclairé par sa corruption, celle-ci le ramenait 


\section{Notes}

à la nature. Quand Rome finit, Rome était stö̈cienne, quand la Grèce finit, elle était philosophe, et dans l'un et l'autre on riait des lois du magistrat et des dieux." DDS. Book I, Chapter VIII. Saint-Just - Duval, 931.

${ }^{18}$ See $p .129$ below for the understanding of revolution used herein.

${ }^{19}$ See Taylor, Chapter 2 for Robert Owen as an example of this; for evidence for Pierre-Joseph Proudhon as one who believed in and worked on the realization of his utopian ideas, see Vincent, K. Steven. 'Pierre-Joseph Proudhon and the Rise of French Republican Socialism'. (Book Review), History of European Ideas, Vol. 7 , Issue 6, 1986.

${ }^{20}$ Taylor, 2.

${ }^{21}$ Dayan- Herzbrun, 73.

${ }^{22}$ Vazquez, 204.

${ }^{23}$ Vazquez, 209.

${ }^{24}$ Freeden (1996), 27.

${ }^{25}$ See Freeden (1996), 16-17.

${ }^{26}$ Freeden (1996), 16.

${ }^{27}$ The use of the term 'external validity' and 'internal validity' is an extrapolation of their use in the field of research design and methodology, where the basic meaning of 'internal validity' is internal consistency within a design or study or system. This is contrasted to external validity, or the ability to generalize or to make inferences drawn from within a study or system valid outside of that study or system.

${ }^{28} \mathrm{I}$ borrow the term from Freeden. See Freeden (2005), $239 \mathrm{ff}$.

${ }^{29}$ Ball, 3.

${ }^{30}$ The understanding of right herein is that right is the source or arbiter of moral correctness. The idea of right requires a base or arbiter of correctness, and this has been found traditionally to be ultimately in the idea of nature. Saint-Just, though still writing in the discursive tradition of the natural and of natural right, moves the social to the fore as the locus of the basis of right, and makes this basis relational, in his assertion that social relations are the essence of society and the basis of right. On the level of the purely theoretical, though he ties the social back to the natural, he creates a basis for the idea of right and the beginnings of a fundament for morality that portend the end of nature as its basis. Jean Jaurès employs a newer sense of right: "[le] fondement des règles régissant les rapports des hommes en société, et impliquant une répartition équitable des biens, des prérogatives et des libertés." (Trésor de la Langue Française. Centre nationale de la recherche scientifique, n.d.; online access at http://atilf.atilf.fr/) and with this definition one can see more clearly Saint-Just's historical position between two conceptions of right.

${ }^{31}$ Discours sur la constitution de la France. Saint-Just - Duval, 419.

${ }^{32}$ Hibben, $v$.

${ }^{33}$ On the public intellectual, especially in the U.S., see for example John Lachs. 'Can Philosophy Still Produce

Public Intellectuals?' Philosophy Now, May- June 2012, online edition.

${ }^{34}$ See in Joy James's and Edmund T. Gordon's 'Afterword' to Hale, at 371.

${ }^{35}$ Ibid.

${ }^{36}$ Barthes also connects the petit bourgeoisie class to a tendency to abstraction. See Barthes, 151 .

${ }^{37}$ Hannah Arendt, for one, discusses the distinction and also relates it to action. See Arendt's The Promise of Politics.

${ }^{38} E$.g. Saint-Just's consideration of Lycurgus, Numa, Montesquieu, Rousseau, Bossuet, and Mably in the formulation of his political theory.

${ }^{39}$ Arendt (2009), 54.

${ }^{40}$ Liénard: "Les auvres purement théorique de Saint-Just sont assez peu nombreuses, et il est même abusif de les considérer comme purement théoriques." In Saint-Just - Liénard, 10. See Soboul's discussion on p. 25 of SaintJust - Soboul.

${ }^{41}$ DDS, Book I, Chapter VIII. Saint-Just - Abensour, 1055.

${ }^{42}$ Discours sur la constitution de la France. Saint-Just - Abensour, 535.

${ }^{43}$ The historical facticity of Lycurgus the man is considered dubious by some scholars. (For this see for example S.E. Vasileos Tsichlis, 'Aspects of Spartan Constitution'. Sparta, Vol. 5, No. 2, December 2009 and J. Adam's review of $\mathbf{H}$. Bazin's 'De Lycurgo in facultate litterarum parisiensi ad doctoris gradum promotis disseruit' in English Historical Review, Vol. II, No. 5, 1887, 153-155.) Herein, 'Lycurgus' will be understood to refer to the ideas attached to the historical personage, and not necessarily to an actual person.

Saint-Just himself never evidences any doubt about the person Lycurgus being the source of the ideas attributed to him or about his being the source of reformed Spartan political institutions and practices, but an 
exploration of why this is so is beyond the scope of this work, and the ideas themselves are what is relevant for the purposes of the questions explored here.

${ }^{44}$ Definitions are taken from Merriam-Webster Unabridged online.

${ }^{45}$ Examples abound, but prominent in this tradition of emphasis on nature are Aristotle, Hobbes, Hume, Locke, and Rousseau.

${ }^{46}$ See note 40 above.

${ }^{47}$ This occurs in Rousseau's notion of the perfectibility of human beings,, which, in contradistinction to Aristotle's notion of perfectibility, has a historical aspect; it is this perfectibility which is, in part what allows for the

historical progression of man into society.. Perfectibility in Rousseau is seen in the Discourse on Inequality, for example, as a 'faculty' of natural man. See Rousseau - Muller, pp. 20-21.

${ }^{48}$ Refer to for example, p. 94 of Rousseau's Considérations sur le gouvernement de Pologne. London: Publisher Unknow, 1782. Online Edition.

${ }^{49}$ Rousseau - Gourevitch, viii.

${ }^{50}$ Rousseau-Muller, 20-21.

${ }^{51}$ lbid.

${ }^{52}$ On the separation of circumstance and development from nature, see Rousseau - Muller, 20-21.

${ }^{53}$ DDS, Book III, Chapter III. Saint-Just - Abensour, 1083.

${ }^{54}$ See DDS, Book IV, Chapter IV. Saint-Just - Abensour, 1051.

${ }^{55}$ See below at p. $62 \mathrm{ff}$ for further discussion of this.

${ }^{56}$ DDS, Book I, Chapter V. Saint-Just - Duval, 929.

${ }^{57}$ FIR. Saint-Just - Abensour, 1094.

${ }^{58}$ FIR. Saint-Just - Abensour, 1091.

${ }^{59}$ Regarding this desire in Saint-Just for a transhistorical nature, see for example Saint-Just - Liénard, 16.

${ }^{60}$ Soboul: "Comme la plupart des hommes de son temps, [Saint-Just] ne pense pas qu'il puisse exister des lois de l'évolution historique..." in Saint-Just - Soboul, 26.

${ }^{61}$ On Kant's replacement of nature with reason as the criterion of judgement, see for example Kuehn, p. 175.

${ }^{62}$ For Rousseau this occurs within the idea of the choice between combat and flight. See Rousseau - Muller, 10 11; for Montesquieu in this regard, see Book 1, Part 1, Chapter 2 of Spirit of the Laws.

${ }^{63}$ Ibid.

${ }^{64}$ DDS, Book I, Chapter II (Strikethrough). Saint-Just - Abensour, 1045.

${ }^{65}$ Compare here for example Xenophon's statements about the esteem of old age in Sparta and the Lycurgan Council of Elders in his Polity of the Athenians and the Lacedaemonians (Xenophon, 25) with statements of Saint-Just in the Fragments such as "Les hommes qui auront vécu sans reproche toute leur vie porteront une écharpe blanche à soixante ans.." and "Le respect de la vieillesse est un culte." (FIR - Saint-Just - Duval, 999). ${ }^{66}$ DDS, Book II, Chapter VI. Saint-Just - Abensour, 1066.

${ }^{67}$ DDS, Book III, Chapter I. Saint-Just - Abensour ,1079.

${ }^{68}$ DDS. Book I, Chapter IX. Saint-Just - Abensour, 1057.

${ }^{69}$ DDS. Book III, Chapter I. Saint-Just- Abensour, 1079.

${ }^{70}$ DDS. Book IV, Chapter II. Saint-Just- Abensour, 1082.

${ }^{71}$ DDS. Book I, Chapter II. (Earlier Version). Saint-Just - Abensour, 1045.

${ }^{72}$ The unclear division between the concept of the state of nature and he concept of the social state lies partly in the former's real existence as a functionality - as a base or origin to give credence to the concept of the social, and partly in the incomplete historical elaboration of the social after Saint-Just; from a more fully developed

elaboration one might better retrospectively comprehend Saint-Just historically.

${ }^{73}$ See note 30.

${ }_{74}^{74}$ Abensour (1966), 26. Cf. note 61 .

${ }^{75}$ DDS, Book I, Chapter III. Saint-Just - Abensour, 1048-1049.

${ }^{76}$ In Rousseau, the concept appears, for example, as the "common element of different interests" and in the idea of social rights. See Rousseau - Cole, pages 22 and 27 (Social Contract Book II, Sections 3 and 4). In Montesquieu, the idea of the social as it appears in Saint-Just is akin to what Montesquieu calls civil right (See Spirit of the Laws, Part I, Book 1, Chapter 3, and Part V, Book 26, Chapter 1).

${ }^{71}$ See for example, Rousseau - Cole, 47 (Social Contract, Book I, Chapter 12).

${ }^{78}$ Accordingly, see the Practice section for discussion of the particular content of the social in Saint-Just.

${ }^{79}$ Jannet, 43.

${ }^{80}$ Speech on the Constitution of France. Saint-Just - Abensour, 536.

${ }^{81}$ Speech on the Constitution of France. Saint-Just - Abensour, 538. 
${ }^{82}$ Speech on the Constitution of France. Saint-Just - Abensour, 538.

${ }^{83}$ Abensour, Miguel. 'Saint-Just and the Problem of Heroism in the French Revolution.' in Fehér, 140.

${ }^{84}$ Speech on the Constitution of France. Saint-Just - Soboul, 99.

${ }^{85}$ See note 38.

${ }^{86}$ 'Type vécu' is how Nietzsche incorrectly describes Richard Wagner's character Kundry, but might better have described Siegfried, a Wagnerian character akin to Saint-Just. (See Beyond Good and Evil, Book III, § 47).

${ }^{87}$ DDS, Book I, Chapter II (Earlier Version). Saint-Just - Abensour ,1046.

${ }^{88}$ DDS, Book I, Chapter II (Earlier Version). Saint-Just - Abensour, 1048.

${ }^{89}$ Ibid., 1045.

${ }^{90}$ lbid., 1046

${ }^{91}$ DDS, Book I, Chapter VIII. Saint-Just - Abensour, 1056.

${ }^{92}$ Ibid.

${ }^{93}$ DDS, Book II, Chapter VI. Saint-Just - Abensour, 1066.

${ }_{94}^{94}$ Saint-Just - Abensour, fin 27, 1226 (Strikethrough).

${ }^{95}$ See in this regard Nichols' discussion of Alexandre Kojève's analysis of Rousseau at Nichols, 886.

${ }^{96}$ See Herbert Marcuse, Reason and Revolution. Boston: Beacon Press, 1966, Part II, Introduction, 251-257.

97 "La redéfinition de phénomènes politiques et moraux en tant que phénomènes « sociaux» conduisit à un mode de pensée nouveau, plus général et plus abstrait." Heilbron, Johan. Naissance de la sociologie. Part I: La Construction des Théories Sociales. Livres en Ligne - Agone Paper Edition 2006. Online version Section 34. See also Herbert Blumer on the conceptual inadequacy of the phenomena grouped under the heading social for the purposes of empirical sociology in Blumer, Herbert. 'What Is Wrong With Social Theory?" American Sociological Review, Vol. 19, No. 1 (Feb., 1954), pp. 3-10.

${ }_{98}$ Speech of 9 Thermidor, Year II. Saint-Just - Abensour, 769.

${ }^{99}$ DDS, Supplement. Saint-Just - Liénard, 180.

${ }^{100}$ FIR. Saint-Just - Abensour, 1126.

${ }^{101}$ The people are privileged by Saint-Just in his placing of governors beneath them.

${ }^{102}$ DDS, Book II, Chapter II. Saint-Just - Abensour, 1061.

${ }^{103}$ DDS, Book II, Chapter VI. Saint-Just - Abensour, 1066.

${ }^{104}$ DDS, Book II, Chapter I. Saint-Just - Abensour, 1059.

${ }^{105}$ Specifically, improper or illegitimate commerce for Saint-Just, commerce which would lead to inharmoniousness in society is described in Du Droit Social as: any commerce of property (all commerce is of the civil realm; one cannot sell oneself or one's minimum land allotment since the latter is part of the common property of the society), any commerce that does not satisfy needs, and any commerce made possible by hoarding. Saint-Just did not discuss the possibility of a nonmonetary economy, but many of the problems that the Revolutionary government faced in the area of commerce had to do with manipulations of money. In the Rapport Sur La Police Générale, Saint-Just discusses some specifics of how factions and elements of the counterrevolution engaged in improper commerce, and used such to contravene the Revolution.

${ }^{106}$ DDS, Book II, Chapter VI. Abensour, 1066.

${ }^{107}$ DDS, Book II, Chapter II. Saint-Just - Abensour, 1060.

${ }^{108}$ A note of Saint-Just to himself in the manuscript of DDS is testimony to this development-in-process which is the civil conceptually: ..."il faut chercher quel sera le principe de la règle civile..."; see in Saint-Just Abensour, 1226, fn 28. And in Book II, Chapter V of DDS, one finds "cherchons une règle invariable et solide de l'état civil," followed by hesitation to name it.

${ }_{109}^{109}$ DDS, Book II, Chapter III. Saint-Just - Abensour, 1062.

${ }^{110}$ DDS, Book II, Chapter III. Saint-Just - Abensour, 1063. Saint-Just's political philosophy modulates between liberal, individualistic ideas of personhood, and more communal ideas of personhood, and this, and the fact that he left work unfinished, accounts to some extent for the underdevelopment of his idea of independence. Saint-Just was not able to finish Du Droit Social, in which he began to address the social pact as, since it is part of contract theory, an incorrect way of thinking about human society, but nevertheless a reality insofar as the corrupt civil realm was a reality (See Chart of Relations). Cf. notes 83 and 84 above, where the passages in which Saint-Just addresses the independence of individuals interiorly, in the au-dedans, are superseded by his later work, which does not yet include any serious elaboration of independence among persons in the social circle. This fact could be perhaps taken as evidence of the order of Saint-Just's revisions of DDS before his death. The difficulty in articulating an idea of independence that was so modulated, or of an idea of independence that was different from the idea of independent personhood in developing liberal 
republics is not unique to Saint-Just, and he may have inherited this difficulty from some of his predecessors; cf. note 245, which references Morelly's poorly spelled out idea of independence in mutual dependence.

${ }^{111}$ DDS, Book II, Chapter VI. Saint-Just - Duval, 940.

${ }^{112}$ DDS, Book II, Chapter II. Saint-Just - Abensour, 1060.

${ }^{113}$ DDS, Book II, Chapter II. Saint-Just - Abensour, 1061.

${ }^{114}$ DDS, Book II, Chapter III. Saint-Just - Abensour, 1063.

${ }^{115}$ Although this description of negation in Hegel is my own, see Zizek's similar description in Chapter 5 of Zizek,Slavov. Less Than Nothing: Hegel and the Shadow of Dialectical Materialism. New York: Verso, 2012.

${ }^{116}$ Nail, Thomas. 'Constructivism and the Future Anterior of Radical Politics.' Anarchist-Developments in Cultural Studies 2010: 1, 85.

${ }_{117}$ Abensour (1966), 18.

${ }_{118}^{118}$ Abensour (1966), 21-22.

${ }_{119}^{119}$ DDS Book I, Chapter IV. Saint-Just - Abensour, 1051.

${ }^{120}$ lbid.

${ }^{121}$ DDS, Book I,Chapter X. Saint-Just-Abensour, 1058.

${ }_{122}^{12}$ Discours sur la constitution de la France, Saint-Just - Soboul, 98.

${ }^{123}$ lbid.

124 lbid.

${ }^{125}$ DDS. Book I, Chapter II (superseded). Saint-Just - Duval, 924.

${ }^{126}$ DDS. Book I, Chapter II (superseded). Saint-Just - Duval, 925.

${ }^{127}$ Saint-Just - Cassou, 286.

${ }_{128}$ Saint-Just - Cassou, 286-287.

129 Soboul (1951), 337.

${ }^{130}$ Friedrich Nietzsche, Beyond Good and Evil Rolf Peter Horstmann, ed., Judith Norman, trans. Cambridge University Press, 2003, Section 61.

${ }^{131}$ See Bar On, Bat Ami 'Normativity, Feminism, and Politics', in Lisa Tessman, ed. Feminist Ethics and Social and Political Philosophy. Theorizing the Non-Ideal. New York: Springer, 2009

${ }^{132}$ See notes 380 and 381 below.

133 'phronesis'

134 Volpi, Franco, 'The Rehabilitation of Practical Philosphy' in Bartlett, Robert C. and Susan D. Collins, eds. Action and Contemplation. Studies in the Moral and Poltiical Thought of Aristotle. Albany, N.Y.: State University of New York Press, 1999, 23.

${ }^{135}$ DDS, Book I, Chapter II. Saint-Just - Abensour, 1058.

${ }^{136}$ Discours du 9 Thermidor, An II. Duval, 912.

${ }^{137}$ See for example his comments in Book I, Chapter VIII and Book II, Chapter IV of DDS.

${ }_{138}^{138}$ Aulard (1904), viii.

139 FIR. Introduction. Saint-Just - Liénard, 252.

${ }^{140}$ See Quennedey, Annexe II, 147.

${ }^{141}$ The members of the Committee of Public Safety and the Committe of General Security, and others who were theoretically and practically aligned with the Revolutionary ideas of Robespierre and Saint-Just, virtually all resigned or turned against the increasingly reformist government within a relatively short time after Saint-Just's execution.

${ }_{142}$ See fn 126 above.

143 "...le projet de Saint-Just servit de base à la Constitution définitive et ....plusieurs de ses articles furent insérés sans aucune modification." (Centore-Bineau, 108).

${ }^{144}$ See discussion of this in the Biography herein above.

${ }^{145}$ See for example Abensour (1966), 25ff. and Saint-Just - Liénard, 14ff.

${ }^{146}$ For Rousseau's valuation of Lycurgus, see for example Rousseau - Cress, $20 \mathrm{fn}$.

${ }^{147}$ Discours sur la division constitutionelle du territoire. Saint-Just - Abensour, 577.

${ }^{148}$ Saint-Just - Liénard, 14.

${ }^{149}$ Discours sur la constitution de la France. Saint-Just - Abensour, 535.

${ }_{151}^{150}$ FIR. Saint-Just - Abensour, 1136.

${ }^{151}$ Comninel, George C. Rethinking the French Revolution: Marxism and the Revisionist Challenge. New York: Verso, 1990 (Second Edition), 45.

${ }^{152}$ Vogel, Steven. Against Nature: The Concept of Nature in Critical Theory. Albany, N.Y.: State University of 
New York Press, 1996, 88.

${ }^{153}$ I understand the term 'epistēme' in its discursive, Foucauldian sense.

${ }^{154}$ Cobban, 16.

${ }^{155}$ Soboul in Greenlaw, ed., 18.

156 lbid.

${ }^{157}$ Cobban, $16 \mathrm{ff}$.

${ }^{158}$ The goals of the institutions described in the Fragments include 'to put union into families', 'to link men by noble relations', and 'to put these relations in harmony'. (FIR. Saint-Just - Liénard, 253). «....après la destruction Des factions criminelles qui menaçaient la Convention Nationale m'inspirerent Le dessein genereux, D'effectuer la garantie pratique du gouvernement...» FIR. Saint-Just - Liénard, 252. (Liénard here follows Saint-Just's actual orthography and punctuation).

${ }^{159}$ FIR. Saint-Just - Liénard, 302.

${ }^{160}$ FIR. Saint-Just - Liénard, 253.

${ }^{161}$ EDR, Saint-Just - Liénard, 74.

162 Vinot, 270.

${ }^{163}$ Discours sur la constitution de la France. Saint-Just - Duval, 429.

${ }^{164}$ Discours sur la division constitutionelle du territoire. Saint-Just - Duval, 443.

${ }^{165}$ Godechot, (1961), 218-219.

${ }^{166}$ See for example FIR, Saint-Just - Abensour, 1109-1110.

${ }^{167}$ Saint-Just however, favored freedom of religion, and also favored nature's divinity over that of reason, and actually proposes the former as the supreme entity. See FIR, Saint-Just - Abensour, 1118.

${ }^{168}$ Discours sur la constitution de la France. Saint-Just - Duval, 423.

169 Ibid.

${ }^{170}$ FIR. Saint-Just - Abensour, 1089.

${ }^{171}$ Billaud-Varenne, to take one example, writes: “...trop rarement une législation mieux raisonée a su consacrer la félicité de tous par le règne des vertus civiques et par la répression des passions liberticides," Billaud-Varenne, 66.

${ }^{172}$ DDS, Book I, Chapter III. Saint-Just - Abensour, 1050.

${ }^{173}$ FIR. Saint-Just - Nodier, 281.

${ }^{174}$ EDR. Saint-Just - Duval, 281.

${ }^{175}$ DDS. Book II, Chapter VII. Saint-Just - Abensour, 1067.

${ }^{176}$ The mysticism of liberalism comes from its tendency to insist on moderation and reformism even when its own foundational logic and political philosophy call for radical change and its means, revolution. When liberal reformism follows its own logic and this logic leads, as it sometimes does, to a mandate for radical or revolutionary action, liberal thought tends to turn back on its own conclusions and must consequently develop a false logic of reform, a "logic" which is really not a logic at all, since it is actually inconsequent and illogical, but rather an ad hoc and contingent state of denial and avoidance of revolution. It is this inconsequence and illogicality which is here labeled "liberal mysticism". Evidence of this is found for one in the fact that the American republic has seen no "political" revolutions, even though Thomas Jefferson predicted that these would likely be frequently necessary and, in a letter to William Smith, expressed the absurdity of a republic with infrequent rebellions. (See Randolph, Thomas Jefferson, ed. Memoirs, Correspondence, and Private Papers of Thomas Jefferson. Vol. II. London: Henry Colburn and Richard Bentley, 1829, 268.)

${ }^{177}$ FIR. Saint-Just - Abensour, 1109.

${ }^{178}$ FIR. Saint-Just - Abensour, 1102-3.

${ }^{179}$ FIR. Saint-Just - Abensour, 1126,

${ }^{180}$ FIR. Saint-Just - Nodier, 39.

${ }^{181}$ Discours sur la constitution de la France. Saint-Just - Abensour, 545.

${ }^{182}$ Discours sur la constitution de la France. Saint-Just - Abensour, 546.

${ }^{183}$ For evidence of this with regard to Jean Bon Saint-André, see "Charles-Louis Antiboul" http://fr.wikipedia.org Online Encyclopedia accessed 5/17/11; with regard to Georges Couthon, see " Georges Auguste Couthon" http://www.assemblee-nationale.fr/sycomore/fiche.asp?num_dept=12269, accessed 5/17/11.

${ }^{184}$ See Sieyès.

${ }^{185}$ Discours sur les attributions de la ministre de la guerre. Saint-Just - Abensour, 523.

${ }^{186}$ Discours sur les attributions de la ministre de la guerre. Saint-Just - Abensour, 525.

${ }^{187}$ Discours sur les attributions de la ministre de la guerre. Saint-Just - Abensour, 524.

${ }^{188}$ Discours sur les attributions de la ministre de la guerre. Saint-Just - Abensour, 525. 
${ }^{189}$ Discours sur les attributions de la ministre de la guerre. Saint-Just - Abensour, 524.

${ }^{190}$ Discours sur la constitution de la France. Saint-Just - Duval, 425.

191 lbid.

192 Discours contre Beurnonville. Saint-Just - Duval, 414.

${ }^{193}$ Lenin, Vladimir, 'The State and Revolution', Collected Works. Lenin Internet Archive at Marxists.Org, 1999. Chapter 1, Section 4. The notion of the withering away of the state is not originally Lenin's, but Lenin gives an elaboration of it which is helpful in comparison to its presence in the work of Saint-Just.

194 Lenin, Chapter 1, Section 4.

195 The question of the idea of the state in Saint-Just is beyond the scope of this work, yet important portents and potentialities for the state of the future emerge from examination of the idea of a Saint-Justian state in practice.

196 'la morale'

197 Discours sur les subsistences. Saint-Just - Abensour, 487.

198 Aristotle, for example, describes ethics in this traditional sense, and even in relation to action (Nicomachean Ethics Book VI, Chapter I1), but does not discuss ideation from a mode of action as a something pertinent to thought per se; likewise interestingly, although his question is not precisely one of political philosophy, Abensour discusses the thought of Saint-Just entirely within the traditional domain of the contemplative (See Abensour, Avril-Juin 1966, Part III).

${ }^{199}$ See the discussion of some elements of Rousseau's conception of nature at p.34ff.

${ }^{200}$ Discours sur les subsistences. Saint-Just - Abensour, 488.

${ }^{201}$ On Saint-Just's use of 'king' see p. 54 supra.

${ }^{202}$ Discours sur les subsistences. Saint-Just - Abensour, 489.

${ }^{203}$ Discours sur les subsistences. Saint-Just - Abensour, 486.

204 The term 'closed society' draws it origins here from the idea in Karl Popper's The Open Society and its Enemies (Princeton, N.J.: Princeton University Press, 1966). Closed societies in Popper's sense are often merely societies which attempt to keep markets and their abuses out of societies. This idea of exclusion of markets is present to some extent in Saint-Just, but he does not reject markets altogether, only a certain level of abuse arising therefrom, such as speculation and excess accumulation of unproductive wealth. Of importance also is that much of the content of the political in Saint-Just, of that which is banned to the exterior, is of the economic realm, and yet Saint-Just places all economic abuses in the domain of the political in their origin, and creates a critical philosophy of the political, rather than, as Marx and others later, an economic analysis of society.

${ }^{205}$ Discours sur les subsistences, Saint-Just - Abensour, 488.

${ }^{206}$ FIR. Saint-Just - Duval, 989.

${ }^{207}$ Rapport sur la loi contre les Anglais, Saint-Just-Abensour, 646.

${ }^{208}$ Rapport sur la loi contre les Anglais. Saint-Just - Abensour, 652. The word 'traitant' is used here in an obsolete eighteenth century sense which denotes a financier who collects taxes, duties, and debts for the king in exchange for payments.

${ }^{209}$ See Rawls, Introduction.

${ }^{210}$ Rawls, 4.

211 Rawls, 24.

212 Rawls, 24.

${ }^{213}$ See in Popkin, Jeremy. A Concise History of the Haitian Revolution. West Sussex, U.K.: John Wiley \& Sons, 2012, p. 33.

214 Rawls, 13.

215 See note 182.

${ }^{216}$ The basis for many of these critiques is Marx's theory of commodity fetishism. See note 254 below.

${ }^{217}$ Rapport sur la loi contre les Anglais. Saint-Just - Abensour, 652.

${ }^{218}$ In the introduction to The Law of Peoples, Rawls explains these criteria of differentiation: In $\$ 58$ of A Theory of Justice I indicated how justice as fairness can be extended to international law...for the limited purpose of judging the aims and limits of just war. Here my discussion covers more ground. I propose considering five types of domestic societies. The first is reasonable liberal peoples; the second, decent peoples.... The basic structure of one kind of decent people has what I call a "decent consultation hierarchy" and these peoples I call "decent hierarchical peoples". Other possible kinds of decent peoples I do not try to describe, but simply leave in reserve, allowing that there may be other decent peoples whose basic structure does not fit my description of a consultation hierarchy, but who are worthy of membership in a Society of Peoples. (Liberal peoples and decent peoples I refer to together as "well-ordered peoples.") There are third, outlaw states, and fourth, societies burdened by unfavorable conditions. Finally, fifth, we have societies that are 


\section{Notes}

benevolent absolutisms: they honor human rights; but because their members are denied a meaningful role in making political decisions, they are not well ordered. (Rawls, 4).

${ }^{219}$ Rawls, 7, 46, and 80.

${ }^{220}$ Rapport sur la loi contre les Anglais. Saint-Just - Abensour, 652.

${ }^{221}$ FIR, Saint-Just - Abensour, 1109.

${ }^{222}$ For some arguments about market determinations as conceptually and analytically formative in Rawlsian theory, see for example Fisk, Milton, 'The State and the Market in Rawls'. Studies in Eastern European Thought. Vol. 30, Number 4 (1985), Nielsen, Kai, 'Rawls and the Left. Some Critiques of Rawls' Principles of Justice'. Analyse \& Kritik 1980 (2), Issue 2, 74-97, and Andrew, Ed. Review of David Johnston 'The Idea of A Liberal Theory. A Critique and Reconstruction.' Canadian Journal of Political Science 30 (1997), 188-189.

${ }^{223}$ On the issue of international capital, markets and consumerism and their determination of concepts relevant to the individual in liberal society see for example Smart, Barry. Consumer Society. Critical Issues and Environmental Consequences. Portsmouth, U.K.: Sage Publications, 2010, Thomas Lemke. 'The Birth of BioPolitics: Michel Foucault's Lecture at the Collège de France on Neo-Liberal Governmentality', Economy and Society. Volume 30, Issue 2, 2001: 190-207, C.B. MacPherson. The Rise and Fall of Economic Justice and Other Papers. New York: Oxford University Press, 1985, and Halpern, Cynthia Perwin. 'Property, Privacy, and Power.' Paper Prepared for Delivery at the Annual Meeting of the American Political Science Association, New York, NY, 1994.

${ }^{224}$ Amy Gutmann, for example, describes such questions as her main motivation for writing Liberal Equality (New York: Cambridge University Press, 1980); Howard F. Chang argues that liberal states must reform themselves with regard to the phenomena of international labor migration ('The Economics of International Labor Migration and the Case for Global Distributive Justice in Liberal Political Theory'. Cornell International Law Journal Vol. 41, No. 1, 2008).

${ }^{225}$ EDR. Saint-Just - Liénard, 125.

${ }^{226}$ An early meaning of $\theta \varepsilon \omega \rho i \alpha$, perhaps that from which the philosophical sense grew, is 'watching', and thus it has, with regard to action, the removed sense of the spectator; Plato discusses $\theta \varepsilon \omega \rho i \alpha$ with regard to its incommunicability, and thus its distance from non-philosophers, and Aristotle separates the life of the philosopher from that of the politician, stressing that they involve different objects of knowledge. The character of the life of $\theta \varepsilon \omega \rho i a$ has for Aristotle philosophical knowledge, or knowledge of the eternal, and the life devoted to $\theta \varepsilon \omega \rho i a$ is the contemplative life. The foregoing is discussed very helpfully in Ball, ed., especially in the sections written by Nicholas Lobkowicz and Ball.

${ }^{227}$ This is a central idea of the work of Alain Badiou. See Alain Badiou, What Is Philosophy? Videotape of Public Lecture at the European Graduate School, 2010.

228 «Le droit du premier possesseur d'un champ fut sa charrue, le droit de ses enfants fut sa possession.»DDS. Book II, Chapter XIV. Saint-Just - Abensour, 1077.

${ }_{229}$ DDS. Book II, Chapter XIV. Saint-Just - Abensour, 1077.

${ }^{230}$ FIR. Saint-Just - Abensour, 1109.

${ }^{231}$ DDS, Book II, Chapter XIV. Saint-Just - Abensour, 1078.

${ }^{232}$ DDS, Book II, Chapter XIV. Saint-Just - Abensour, 1078.

${ }^{233}$ EDR, Book I, Chapter II, Saint-Just - Abensour, 368.

${ }^{234}$ DDS, Book II. Saint-Just - Abensour, 1059 infra.

${ }^{235}$ DDS, Book I, Chapter VII. Saint-Just - Abensour, 1054.

${ }^{236}$ Ibid.

${ }^{237}$ DDS, Book II, Chapters V and VI, Saint-Just - Abensour, 1065-1066.

${ }^{238}$ A comparison of Saint-Just's idea of 'affections' to Mably's Principes de Morale is relevant here. Mably had posited a society founded on relations that were, at base, "affections of the soul", however Mably considered the relations which developed out of these affections to be new relations. In Saint-Just's work it is less clear that the social relations of love and affections are entirely new, or even necessarily new at all. Another difference from Mably is that whereas Mably equivocates on the role of passions, writing that they can equally serve virtue or vice, Saint-Just takes a more purely negative view of the passions as bases of society, and seems to distinguish them more from 'affections' than does Mably. Of note is the fact that, in the inventory of Saint-Just's library taken after his death, one of the books inventoried was Mably's Principes de Morale.

${ }^{239}$ Discours sur les subsistences. Saint-Just - Abensour, 487.

${ }^{240}$ Ibid.

${ }^{241}$ Two specific examples of the view of Saint-Just's thought as bourgeois are Liénard and Marin, Louis, who discusses Saint-Just in Utopiques. Jeux d'espaces. Paris: Les Éditions de Minuit, 1973. 
${ }^{242}$ Discours sur les subsistences. Saint-Just - Abensour, 489

${ }^{243}$ See Soboul (1967), 71

${ }^{244}$ Godechot (1951), 401.

${ }^{245}$ Godechot, (1951), 400.

${ }^{246}$ See Ollivier for this understanding of Saint-Just.

${ }^{247}$ This quote is found on one of the papers found in the quarters of Saint-Just at the time of his arrest and death. Abensour and Kupiec include this paper as 'Complement au Carnet'. Saint-Just - Abensour, 1147.

${ }^{248}$ Discours sur les subsistences. Saint-Just - Abensour, 491.

${ }^{249}$ FIR. Saint-Just - Abensour, 1096.

${ }^{250}$ I use the term in its Marxian definition as the adoption of class interests other than those of one's own class in the mistaken belief that these can serve one's needs. The adoption of the needs of an economic class that is not one's own then in turn creates false needs, the meeting of which needs serves only the interests of the capitalist class.

${ }^{251}$ Their character is revolutionary as it is defined in a radical tradition concerned with egalitarian justice. On Solon's radicality, see Castoriadis, Carlos. 'Pouvoir, Politique, Économie', Revue de Métaphysique et de Morale, 93e Anné, No. 1, John Rawls Le Politique (Janvier-Mars 1988), 94. Castoriadis places Solon in the radical heritage of the "Cleisthenian Revolution". On the radicality and revolutionary character of the Gracchi, see Nicolet, Claude. Les Gracques, la crise agraire, et révolution d Rome. Paris: Gallimard, 1980.

${ }^{252}$ Rapport sur les factions de l'étranger. Saint-Just - Abensour, 692

${ }^{253}$ Rapport sur les factions de l'étranger. Saint-Just - Abensour, 688.

${ }^{254}$ It is important here also to be careful not to impute reasons for worker's lack of 'theorizing', or lack of articulation and conveyance of needs and ideas, based on bourgeois analyses themselves. Thus, Marx points out that "The small peasants form a vast mass, the members of which live in similar conditions but without entering into manifold relations with one another. Their mode of production isolates them from one another, instead of bringing them into mutual intercourse. The isolation is increased by France's bad means of communication and by the poverty of the peasants. Their field of production, the small-holding, admits of no division of labour in its cultivation, no application of science, and, therefore, no multiplicity of development, no diversity of talent, no wealth of social relationships." Marx, Karl, quoted in Harris, Nigel, 'The Revolutionary Role of the Peasants.' Debate. (1st series), No.41,December 1969/January 1970, pp.18-24 Reprinted online at www.marxists.org. This is a statement of the forces of disarticulation of the ideas of the workers and, in Saint-Justian terms, of the political relations of force through the processes of production, which relations of force are also relations of disunity.

${ }^{255}$ From the Rapport Fait Au Nom Du Comité de Salut Public Sur L'Approvisionnement des Armées. Saint-Just Duval, 493.

${ }^{256}$ See FIR. Saint-Just - Duval, 967.

${ }^{257}$ Discours sur la constitutions de la France. Saint-Just - Abensour, 535

${ }^{258}$ FIR, Saint-Just - Abensour, 1088.

${ }^{259}$ FIR. Saint-Just - Abensour, 1115.

${ }^{260}$ Quoted from Centore- Bineau, 180.

${ }^{261}$ See Hagopian.

262 "En fait, Saint-Just ne porte pas dans son caur l'économie politique. Il raille Roland de chercher des conseils auprès des économistes pour conjurer la crise des subsistances." (Dommanget, 179).

${ }_{263}$ DDS, Book I, Chapter VIII. Saint-Just - Abensour, 1056.

${ }^{264}$ Hagopian, 344.

${ }^{265}$ The Ordnance brought about both an accessibility to the world of letters to the vernacular consciousness, but also a patriotism and nationalism, which latter disguised transnational phenomena, such as the very class system which produced Latinate education in the first place.

${ }^{266}$ Rapport sur la conjuration. Saint-Just - Abensour, 707.

${ }^{267}$ Rapport sur la police générale, Saint-Just - Abensour, 743.

${ }^{268}$ Le Moniteur No. 137, 17 May 1792.

${ }^{269}$ EDR. Part III, Chapter XXIII. Saint-Just - Abensour, 421.

${ }^{270}$ Discours sur la division constitutionelle du territoire. Saint-Just - Abensour, 578.

${ }^{271}$ Ibid.

272 Ibid.

${ }^{273}$ For a discussion of the concept, see Chapter 1 of Rubin, I.I. Essays on Marx's Theory of Value. Delhi: Aakar Books, 2008. 
${ }^{274}$ DDS, Book I, Chapter VII. Saint-Just - Abensour, 1054.

${ }^{275}$ DDS, Book II, Chapter XIV. Saint-Just - Abensour, 1078.

${ }^{276}$ Morelly, 97.

277 Though Billaud-Varenne and Jeanbon Saint-André should not be neglected in this regard.

${ }^{278}$ Very valuable in this vein is Saint-Just's discussion of needs and possession, the essence of the civil realm, in relation to the recent political history of France in FIR. (Saint-Just - Abensour, 1113-1117).

${ }^{279}$ FIR. Saint-Just - Abensour, 1114.

${ }^{280}$ On the relationship of power to force in the area of international studies, where it has been most often discussed in the contemporary period, see Morgenthau, Hans. "A Realist Theory of Political Power" in Essential

Readings in World Politics Karen Mingst and Joe Snyder, eds. New York: Norton, 2004, p. 62 (accessed online); Rothgeb, John M., jr. Defining Power: Influence and Force in the Contemporary International System London: Saint Martin's, 1993 62-63, Harris, Errol. "Political Power and Force in Politics" Ethics Vol. 58 No. 1, October 1957, 1-10.

${ }^{281}$ For a developed idea of the psychology of power, see Firestone.

${ }^{282}$ Relevant here are Abensour's introductory comments to this report at Saint-Just - Abensour, 588.

${ }^{283}$ Rapport sur les 32 membres de la Convention. Saint-Just - Abensour, 622.

${ }^{284}$ Rapport sur les 32 membres de la Convention. Saint-Just - Abensour, 589.

${ }^{285}$ In the naturally accordant social realm, the sovereign is al ways synonymous with the people.

${ }^{286}$ Rapport sur les 32 membres de la Convention. Saint-Just - Abensour, 589.

${ }^{287}$ DDS, Book II, Chapter IV. Saint-Just - Abensour, 1064.

${ }^{288}$ DDS, Book I, Chapter III. Saint-Just - Abensour, 1050.

${ }^{289}$ It should be noted that amitie is often used somewhat more strictly by the French than 'friendship' is by Americans. For many relationships which in English might be referred to as 'friendship', the French would use the word 'copain' or 'camarade'. This understanding of the nature of amitié is consistent with Saint-Just's understanding of the idea.

${ }^{290}$ FIR, Saint-Just - Abensour, 1102 sic passim.

291 EDR, Part III, Chapter III. Saint-Just - Abensour, 399.

292 DDS, Book I, Chapter VIII. Saint-Just - Abensour, 1056.

293 EDR, Part V, Chapter X. Saint-Just - Abensour, 468.

${ }^{294}$ EDR, Part IV, Chapter IX. Saint-Just - Abensour, 436-437.

${ }^{295}$ See Marcuse, $73 \mathrm{ff}$.

296 Mathiez (1918), Chapter VII, 138-177.

297 Mathiez (1918), 198.

298 Godechot (1961), 164.

299 FIR. Saint-Just - Abensour, 1111.

${ }^{300}$ E.g. FIR, Saint-Just - Abensour, 1119, 1143, 1103.

${ }^{301}$ FIR, Saint-Just - Abensour, 1119.

${ }^{302}$ Saint-Just - Cassou, 286.

${ }^{303}$ Billaud-Varenne's Principes régénérateurs du système social was first published in a completed form in the middle of Year III, which indicates that he must have been working on the text, or at least the ideas therein, during Year II.

${ }^{304}$ Information about Saint Just's last speech to the Convention seems to trace back to Michelet, who, in my view, is not altogether credible as a source of information about the Revolution.

${ }^{305}$ The story is that, seven sentences into his speech, he was interrupted by Jean-Lambert Tallien, who was granted the right to speak by Jacques Alexis Thuriot, who was presiding over the Convention proceedings at that moment. (See 'Discours Commencé par Saint-Just', in Saint-Just - Soboul, 203).

${ }^{306}$ DDS, Book I, Chapter VIII. Saint-Just - Abensour, 1056.

${ }^{307}$ FIR. Saint-Just - Abensour, 1102.

${ }^{308}$ DDS, Book I, Chapter VIII. Saint-Just - Abensour, 1056-1057.

${ }^{309}$ Mathiez (1907), 123-124.

${ }^{310}$ FIR. Saint-Just - Abensour, 1103.

${ }^{311}$ Mathiez (1907), 123-124.

${ }^{312}$ FIR. Saint-Just - Abensour, 1103.

${ }^{313}$ FIR. Saint-Just - Abensour, 1103.

${ }^{314}$ Mathiez (1907), 122. The emphasis here is Mathiez's.

315 Discussed above at 109-110. 
${ }^{316}$ Thuillier, 498.

317 Ibid.

${ }^{318}$ FIR. Saint-Just - Vovelle, 166.

319 Antonio Gramsci explains how the idea of human nature is produced by a stage of consciousness which is not yet fully cognizant of the objective conditions and social relations which are the context of conceptualization. By extension, one can imagine that the conceptualization of nature more generally is produced in the same way. For an explication of Gramsci's thought on this question, see Kahn, Beverly. 'Antonio Gramsci's Reformulation of Benedetto Croce's Speculative Idealism' in Martin, James, ed. Antonio Gramsci. Critical Assessments by Leading Political Philosophers. London: Routledge, 2002, 124.

320 Ibid.

${ }^{321}$ Exegetical and textual considerations must be made here of course; in this regard see Abensour $(f n 6,1086)$, whose organization of the Fragments I follow here, except for the emendation made by Quennedy.

${ }^{322}$ FIR. Saint-Just - Vovelle, 163.

${ }^{323}$ FIR. Saint-Just - Vovelle, 167.

${ }^{324}$ DDS. Saint-Just - Abensour, 1046 (Earlier Version).

${ }^{325}$ FIR. Saint-Just - Vovelle, 164, DDS. Book I, Chapter II (Earlier Version). Saint-Just - Abensour, 1046.

${ }^{326}$ DDS. Book I, Chapter II. Saint-Just - Abensour, 1046 (Earlier Version).

${ }^{327}$ FIR. Saint-Just - Vovelle, 166.

${ }^{328}$ FIR. Saint-Just - Vovelle, 166.

${ }^{329}$ See Centore-Binau, 184-185.

330 "loi"

331 "propriétê"

${ }^{332}$ Mathiez is quoted by Soboul in this regard at Saint-Just - Soboul, 25. See also Mathiez (1905), 39.

${ }^{333}$ Saint-Just - Soboul, 25.

${ }^{334}$ For example Gauthier, Florence. 'De Mably à Robespierre. Un programme économique égalitaire.' Annales Historiques de la Révolution Française, Vol. 261 (1985), 265-289; Vinot, Bernard. 'Saint-Just: son milieu, sa jeunesse et l'influence de sa formation sur sa pensée et son action politique.' Annales Historiques de la Révolution Française, Vol. 261 (1985), 390-393.

${ }^{335}$ Mathiez (1905), 39.

${ }^{336}$ The Committee of Public Safety was actually divided in relation to different tasks and emphases, and tasks related to distribution were officially accorded not to Saint-Just, but to Robert Lindet and Pierre Louis Prieur (de la Marne).

${ }^{337}$ See Saint-Just - Soboul, 25 and Tanghe, Fernand. Le droit au travail entre histoire et utopie. Brussels: Publications des Facultés Universitaires Saint-Louis, 1989, 147.

${ }^{338}$ Saint-Just - Soboul, 25.

${ }^{339}$ See again $\mathrm{p} .67$ supra.

${ }^{340}$ Vinot, 273.

${ }^{341}$ Vinot, 271.

${ }^{342}$ This by order of the Ecclesiastic Committee of the Constituent Assembly in July, 1990.

${ }^{343}$ See Biographie universelle ou dictionnaire de tous les hommes... [France]: Ode, 1847, 319.

${ }^{344}$ Collot d'Herbois and Billaud Varenne were deported to Caribbean colonies, Vadier was still hiding in the underground when in his eighties and forced to move constantly, Voulland was decommissioned and left destitute, Prieur de la Marne was exiled and died in poverty.

${ }^{345}$ See for example Liénard's conclusions in Saint-Just - Liénard, 29.

${ }^{346}$ In this regard see Soboul's discussion at Saint-Just - Soboul, 26.

${ }^{347}$ See note 310 above. One of the counterrevolutionary and inegalitarian abuses Saint-Just specifies is a system where hoarding by merchants leads to scarcity, which leads to an increase in prices to excessive levels, and where there is also hoarding in order to receive government payments for foodstuffs. The rights to payments for foodstuffs were also bought and sold and Saint-Just makes the assertion that this inegalitarian system of false scarcity and speculation was purposely used by counterrevolutionaries to bring about revolts.

${ }^{348}$ The term 'closed society' was later used by market libertarians and liberal reformists such as Karl Popper to deride modern communistic societies who needed to close themselves off from the deleterious effects of markets, but the term has an unintended relevance both anachronistically for Saint-Just's ideal, and also for a more general understanding of the need for such a society.

${ }^{349}$ FIR. Saint-Just - Abensour, 1108.

${ }^{350}$ FIR. Saint-Just - Abensour, 1087. 
Notes

${ }^{351}$ For some sense of this lineage and the similarities to and differences from later closed societies, see for one Mathiez (1920).

352 Tocqueville (2010), 25.

353 Tocqueville, (2010), 26-27.

${ }^{354}$ See Chapter II of The Old Regime and the French Revolution, which is titled 'That the fundamental and final object of the revolution was not, as some have supposed, to destroy religious and to weaken political authority.'

${ }^{355}$ This conceptual semi-conflation is present in Tocqueville only to the extent that he describes the supposed novelty of the French Revolution in terms which use the concept of the social and which name the locus of this uniqueness and novelty as the ideals of culture.

356 Wolin, 162.

357 Tocqueville (2010), 27.

${ }^{358}$ Examples abound of a clearly universalist or "proselytic" in Tocquevillian terms, language among the Levellers and the True Levellers, or Diggers. To wit: Winstanley, Gerrard. The Law of Freedom in a Platform. n.p., 1652, Chapter I, reprinted at marxists.org,Chapter II, Overton, Richard. 'An Arrow Against All Tyrants', n.p., 1646; pamphlet reprinted at constitution.org, Lilburne, John. Untitled pamphlet, n.p. 1645; reprinted at constitution.org as 'On the $150^{\text {th }}$ Page'.

359 Jardin, in his biography of Tocqueville, describes the food supply crisis of 1817 in the department of Moselle, where Tocqueville, holding office as prefect there early in his career, was forced to sell his plan for feeding the people of the department to investors, instead of being able to impose redistributive measures on them. (Jardin, 23) Jardin also reports Tocqueville's regret that he could not impose other necessary measures with regard to fixing the department's roads, because he had to negotiate with moneymakers and their friends in government. (Jardin, 24) Tocqueville's action as politician remains restricted by the reformist and establishment-confined procedures from which his social theory, though possessing the components of a radical critique, was not able to bring forward.

${ }^{360}$ Mitchell, Harvey. 'Alexis de Tocqueville and the Legacy of the French Revolution' in Fehêr, ed., 240.

${ }^{361}$ Discours sur la constitution de la France. Saint-Just - Duval, 417.

${ }^{362}$ Discours sur la constitution de la France. Saint-Just - Abensour, 546.

${ }^{363}$ Rapport sur le gouvernement révolutionnaire. Saint-Just - Liénard, 235.

${ }^{364}$ See for example, one way in which Francois Fortunet takes note of the movement across theory and action that one inevitably notices in Saint-Just: Nous n'aurons jamais finir de relire Saint-Just, car chaque filet que nous jetons et ramenons a son rythme propre et son réseau de mailles particulier, ceux-là mêmes de nôtre propre écran et vision du monde. A travers l'ensemble des écrits de ce révolutionnaire, nous nous efforçons de saisir les rapports entre les diverses instances du même phénomène, ici l'édification d'une société nouvelle et d'un homme tout aussi nouveau. Fortunet, 182.

${ }^{365}$ At the level of the state or society, the social is defined by Saint-Just as property relations. Consistent with Saint-Just's definition of property, these relations are also described as relations between individuals. (See Chart of Relations and note 312 supra.).

${ }^{366}$ Though the discussion here is in more general terms of relationality, debates about the proper application of the dialectic as Marx redescribed it out of the work of Hegel as a specific relational thought mode are relevant. In Marxian-informed explorations of logical modes and forms, the question is one of whether or not the dialectical form of explanation and understanding can be extrapolated to phenomena other than the history of material circumstance. For instances of this question, see the chapter 'Is Nature Dialectical?' in Novack, George.

Understanding History. Chippendale, N.S.W. Australia: Resistance Books, 2002 (Accessed online at www.marxists.org), and also Bykhovskii, B. 'Marcusism against Marxism: A Critique of Uncritical Criticism.' Philosophy and Phenomenological Research, Vol. 30, No.2 (December, 1969) 203-218 (Accessed online at angelfire.com); Bykhovskii vitriolically critiques improper extrapolations of Marxian dialectics.

367 See Godechot (1951), 299.

368 Ibid.

369 Godechot (1951), 297.

370 Ibid.

${ }^{371}$ Rapport sur la police générale. Saint-Just - Abensour, 763.

${ }^{372}$ Aulard (1909), 497.

${ }^{373}$ Lenin speaks of the need for a provisional revolutionary government to create a positive program of action that may be said to be partially constitutive of the content of the concept 'revolutionary', and Lenin's notion of revolution is less limited temporally than that of Saint-Just. For Lenin, the provisional government of the Russian Revolution is temporary in its form, yet the revolution continues to develop and progress historically, with no 
specified end, whereas for Saint-Just the revolution will end when nature is reestablished as the basis of social relations. See Lenin, V. I. Deux tactiques de la social démocratie dans la révolution démocratique. Trans. unknown. French Edition Geneva: n.p. 1905. Reprinted at marxists.org .

${ }^{374}$ Trotsky describes the idea in The Permanent Revolution: Results and Prospects. Trans. Max Schactman. New York: Pioneer, n.d.

${ }^{375}$ See the Rapport sur les factions de l'étranger

${ }^{376}$ Rapport sur les factions de l'étranger. Saint-Just - Duval, 728.

377 Rapport sur les factions de l'étranger. Saint-Just - Duval, 728

${ }^{378}$ A prototype of the latter, though she died six years before the Revolution, is Rousseau's friend Madame (Louise) D'Epinay.

${ }^{379}$ Rapport sur la nécessité de déclarer le gouvernement révolutionnaire jusqu'à la paix. Saint-Just - Duval, 526.

${ }^{380}$ MacKinnon, 115.

${ }^{381}$ See Chapters 9 and 10 of Firestone.

${ }^{382}$ See Abensour's 'Philosophie Politique de Saint-Just' (Abensour, 1966) for his placement of the master-slave relationship in Saint-Just.

${ }^{383}$ Skocpol: "It is my firm belief that analytic oversimplification cannot lead us toward valid complete explanation of revolutions. If our intention is to understand large-scale conflicts and change such as those that occurred in France from 1787 to 1801 we cannot make progress by starting with objects of explanation that isolate only the aspects that such revolutionary events share with, say, riots or coups. We must look at the revolutions as wholes, in much of their complexity." Skocpol, 5. "It needs to be stressed that comparative historical analysis is no substitute for theory." Skocpol, 39. Even still, Skocpol sticks to the analytic method, and is only concerned with its refinement.

${ }^{384}$ Habermas, 3.

385 See note 14 supra. 